LUZIA DE FÁTIMA PAULA

\title{
IDEIAS LINGUÍSTICAS CONSTITUTIVAS DO PENSAMENTO DE JOÃO WANDERLEY GERALDI SOBRE O ENSINO DE LÍNGUA PORTUGUESA
}

\author{
Universidade Estadual Paulista \\ Faculdade de Filosofia e Ciências \\ Campus de Marília \\ Programa de Pós-Graduação em Educação \\ Marília - SP \\ 12 de março de 2010
}




\title{
LUZIA DE FÁTIMA PAULA
}

\section{IDEIAS LINGUÍSTICAS CONSTITUTIVAS DO PENSAMENTO DE JOÃO WANDERLEY GERALDI SOBRE O ENSINO DE LÍNGUA PORTUGUESA}

\author{
Tese apresentada à Banca Examinadora da Universidade \\ Estadual Paulista (Unesp), Campus de Marília, como \\ requisito parcial para obtenção do título de Doutor em \\ Educação. \\ Orientadora: Prof ${ }^{\mathrm{a}}$. Dra ${ }^{\mathrm{a}}$. Maria do Rosário Longo \\ Mortatti.
}

\section{Universidade Estadual Paulista \\ Faculdade de Filosofia e Ciências \\ Campus de Marília}

Programa de Pós-Graduação em Educação

Área de concentração: Políticas Públicas e Administração da Educação Brasileira

Linha de pesquisa: Filosofia e História da Educação no Brasil 
Marília - SP

12 de março de 2010

LUZIA DE FÁTIMA PAULA

\title{
IDEIAS LINGUÍSTICAS CONSTITUTIVAS DO PENSAMENTO DE JOÃO WANDERLEY GERALDI SOBRE O ENSINO DE LÍNGUA PORTUGUESA
}

\author{
Banca Examinadora
}
Orientadora: Prof ${ }^{\mathrm{a}}$. Dr ${ }^{\mathrm{a}}$. Maria do Rosário Longo Mortatti
Faculdade de Filosofia e Ciências-Unesp-Marília

1ª Examinadora: Prof $^{\mathrm{a}}$. Dr ${ }^{\mathrm{a}}$. Maria do Rosário de Fátima Valencise Gregolin Faculdade de Ciências e Letras-Unesp-Araraquara

2. Examinadora: Dr ${ }^{\mathrm{a}}$. Estela Natalina Mantovani Bertoletti

Universidade Estadual de Mato Grosso do Sul (UEMS)-Unidade de Paranaíba

$3^{\circ}$. Examinador: Dr. Lourenço Chacon Jurado Filho

Instituto de Biociências, Letras e Ciências Exatas (IBILCE)-Unesp-São José do Rio Preto

4. Examinadora: Dr ${ }^{\text {a }}$. Stela Miller

Faculdade de Filosofia e Ciências-Unesp-Marília 
A

meus eternos companheiros: Cida, Jair e Rob. 


\section{AGRADECIMENTOS}

Agradeço a todos aqueles que, direta e indiretamente, participaram de mais um importante momento de minha formação:

a Deus, fonte inesgotável de sabedoria e força;

à minha orientadora de mestrado e doutorado, Prof ${ }^{\text {a }}$. Dr ${ }^{\mathrm{a}}$. Maria do Rosário Longo Mortatti, pela orientação rigorosa, embora eu não tenha conseguido, ao seu ver, contemplar o que me ensinou;

a João Wanderley Geraldi, pelas contribuições para o ensino de língua portuguesa, e, principalmente, por ensinar a importância de nossa incompletude e do excedente de visão, e, em especial, pela cessão de importantes documentos e de entrevista;

aos meus pais, âncoras de minha vida;

ao meu marido, Rob, pela bondade infinita com que me acompanha;

aos meus avós, pelo amor que compartilhamos;

aos meus familiares, pela força;

aos meus amigos: Adalberto, Adelino, Adriana, Amaral, Ana, André, Andréa, Angélica, Áurea, Bernard, Celso, Cíntia, Claudete, Cristiane, Elisangela, Eronides, Fernanda, Flávia, Gabriela, Germana, Giovana, Giza, Glaís, Gustavo, João, Joaquim, Karina, Kátia, Leusenice, Lucimara, Lucinéia, Luzinete, Margarida, Maria Emília, Monalisa, Pedro, Raul, Rosa, Rosane, Sirlêi, Solange, Sulamita, Thierry e Valdemir, pelo apoio e pela oportunidade de aprendizagens infinitas;

aos integrantes do Grupo de Pesquisa "História do ensino de língua e literatura no Brasil" (Gphellb), pelas alegrias e aprendizagens compartilhadas;

às professoras Maria do Rosário Valencise Gregolin e Estela Natalina Mantovani Bertoletti, pelas valiosas contribuições em meu Exame Geral de Qualificação, embora minha orientadora avalie que eu não as tenha conseguido contemplar;

a Maria Luzinete Euclides, bibliotecária da Biblioteca da Faculdade de Filosofia e Ciências, Unesp-Campus de Marília, pela atenção e orientação técnica quanto aos aspectos de normalização bibliográfica desta tese;

ao Conselho Nacional de Desenvolvimento Científico e Tecnológico (CNPq), pela concessão da bolsa de doutorado durante a maior parte do desenvolvimento da pesquisa de que resultou esta tese;

a Telma Maria Murari, responsável pelo arquivo permanente do Arquivo Central do Sistema de Arquivos (SIARQ), da Universidade Estadual de Campinas (UNICAMP), de CampinasSP. 


\section{RESUMO}

Nesta tese de doutorado, apresentam-se resultados de pesquisa vinculada à linha "Ensino de língua portuguesa", do Grupo de Pesquisa e do Projeto Integrado de Pesquisa "História do ensino de língua e literatura no Brasil", ambos coordenados pela professora Dr ${ }^{\mathrm{a}}$. Maria do Rosário Longo Mortatti. Com o objetivo de contribuir para a compreensão de um importante momento da história do ensino de língua portuguesa no Brasil, focalizam-se as ideias linguísticas constitutivas do pensamento de João Wanderley Geraldi (1946- ) sobre o ensino dessa disciplina, apresentadas em seus artigos da coletânea $O$ texto na sala de aula: leitura \& produção (1984) e nos livros Portos de Passagem (1991) e Linguagem e ensino: exercícios de militância e divulgação (1996). Mediante abordagem histórica centrada em pesquisa documental e bibliográfica, desenvolvida por meio dos procedimentos de localização, recuperação, reunião, seleção e ordenação de fontes documentais e de leitura da bibliografia especializada sobre o tema, foi analisado o pensamento de Geraldi sobre o ensino de língua portuguesa, enfocando os aspectos constitutivos de seu sentido. Constatou-se que a proposta de Geraldi para o ensino de língua portuguesa sofreu significativa influência principalmente das ideias franchianas sobre esse ensino, das ideias bakhtinianas sobre linguagem e das ideias linguísticas de origem francesa, que passaram a ser veiculadas no Brasil, a partir da década de 1980, caracterizando o interacionismo linguístico como base teórica de sua proposta para o ensino de língua portuguesa no país.

Palavras-chave: ensino de língua portuguesa. ideias linguísticas. interacionismo linguístico. João Wanderley Geraldi. pesquisa histórica em Educação. 


\begin{abstract}
In this doctorate thesis, the results of a research associated with "Portuguese language teaching" lines are presented. It's part of the research group and the integrated research project entitled "History of language and literature teaching in Brazil", both coordinated by Professor Maria do Rosário Longo Mortatti. In order to contribute to the understanding of an important moment of the Portuguese language teaching history in Brazil, João Wanderley Geraldi's linguistic ideas about Portuguese language teaching were taken from his articles, published in the collection $O$ texto na sala de aula: leitura \& produção (1984) and in the books Portos de Passagem (1991) and Linguagem e ensino: exercícios de militância e divulgação (1996) to be analyzed. Based on historical approach centered in documentary and bibliographical research, developed by means of localization procedures, recovery, gathering, election and ordering of documental sources and specialized bibliography reading about the subject, the elements which constitute Gerald's linguistic thoughts about Portuguese language teaching were analysed. The results obtained show that Geraldi's proposal for Portuguese language teaching suffered significant influence, specially from the franchian ideas about Portuguese language teaching, from the bakhtinian ideas about langage and from the linguistic ideas of French origin, propagated in Brazil in the 1980s, characterizing the linguistic interaccionism as the theoretical base of his proposal for the Portuguese language teaching in Brazil.
\end{abstract}

Key Words: linguistics ideas. linguistic interaccionism. historical research in Education. João Wanderley Geraldi. portuguese language teaching. 


\section{LISTA DE QUADROS}

\begin{tabular}{|l|l|c|}
\hline Quadro 1 & Bibliografia de J. W. Geraldi, por tipo de texto e forma de participação & 63 \\
\hline Quadro 2 & $\begin{array}{l}\text { Bibliografia de J. W. Geraldi, por tipo de texto, forma de participação e ano } \\
\text { de publicação }\end{array}$ & 64 \\
\hline Quadro 3 & Bibliografia de J. W. Geraldi, por década & 73 \\
\hline Quadro 4 & Textos de Geraldi publicados sob o mesmo título, por ocorrência & 75 \\
\hline Quadro 5 & $\begin{array}{l}\text { Periódicos, instituições, locais de publicação e número de artigos de } \\
\text { Geraldi publicados, por ordem alfabética de periódicos }\end{array}$ & 79 \\
\hline Quadro 6 & $\begin{array}{l}\text { Editoras que publicaram livros de Geraldi, por número de ocorrência e } \\
\text { coleções que integram }\end{array}$ & 81 \\
\hline Quadro 7 & $\begin{array}{l}\text { Organizadores e livros em que foram publicados capítulos de livros de } \\
\text { Geraldi, por ordem alfabética de organizador }\end{array}$ & 84 \\
\hline Quadro 8 & $\begin{array}{l}\text { Co-autores de textos com Geraldi, por ordem alfabética de nomes e } \\
\text { respectivas filiações institucionais }\end{array}$ & 96 \\
\hline Quadro 9 & Textos de Geraldi em parceria, por co-autores e número de textos & 98 \\
\hline Quadro 10 & $\begin{array}{l}\text { Bibliografia sobre João Wanderley Geraldi, por tipo de texto/forma de } \\
\text { participação e quantidade de texto }\end{array}$ & 107 \\
\hline Quadro 11 & $\begin{array}{l}\text { Bibliografia sobre João Wanderley Geraldi, por tipo de texto e ano de } \\
\text { publicação }\end{array}$ & 109 \\
\hline Quadro 12 & $\begin{array}{l}\text { Autores mais citados por Geraldi em textos que tematizam diretamente o o } \\
\text { ensino de língua portuguesa, por ordem de ocorrência e filiação } \\
\text { institucional/país de origem }\end{array}$ \\
\hline Quadro 13 & Autores mais citados por Geraldi, por categorias de identificação & 130 \\
\hline
\end{tabular}




\section{LISTA DE SIGLAS}

\begin{tabular}{|c|c|}
\hline ABDEPP & Associação Brasileira para Divulgação, Estudos e Pesquisas da Pedagogia Freinet \\
\hline ABERJE & Associação Brasileira de Comunicação Empresarial \\
\hline ABRALIN & Associação Brasileira de Linguística \\
\hline ABRAPA & Associação Brasileira de Professores de Alemão \\
\hline ADUNICAMP & Associação de Docentes da UNICAMP \\
\hline AEC & Associação de Educação Católica do Brasil \\
\hline ALB & Associação de Leitura do Brasil \\
\hline AMAE & Associação Mineira de Administração Escolar \\
\hline ANDE & Associação Nacional de Educação \\
\hline ANPEd & Associação Nacional de Pós-Graduação e Pesquisa em Educação \\
\hline APEOESP & Sindicato dos Professores do Ensino Oficial do Estado de São Paulo \\
\hline APLL & Associação de Professores de Língua e Literatura \\
\hline APP & Associação dos Professores do Paraná \\
\hline APP & Associação de Professores de Português \\
\hline Assoeste & Associação Educacional do Oeste do Paraná \\
\hline CAPES & Coordenação de Aperfeiçoamento de Pessoal de Nível Superior \\
\hline $\mathrm{CBA}$ & Ciclo Básico de Alfabetização \\
\hline CBE & Conferência Brasileira de Educação \\
\hline CEDAE & Centro de Documentação Cultural "Alexandre Eulálio" \\
\hline CEDES & Centro de Estudos Educação \& Sociedade \\
\hline CENDOTEC & Centro Franco-Brasileiro de Documentação Técnica e Científica \\
\hline CENP & Coordenadoria de Estudos e Normas Pedagógicas \\
\hline CENPEC & Centro de Estudos e Pesquisas em Educação, Cultura e Ação Comunitária \\
\hline CEPELL & Centro de Estudos e Pesquisas Linguísticas e Literárias \\
\hline CIFOP & Centro Integrado de Formação de Professores \\
\hline $\mathrm{CNPq}$ & Conselho Nacional de Desenvolvimento Científico e Tecnológico \\
\hline C.N.R.S. & Centre National de La Recherche Scientifique \\
\hline COLE & Congresso de Leitura do Brasil \\
\hline COMPED & Comitê dos Produtores da Informação Educacional \\
\hline CONACRE & Comitê Nacional de Credenciamentos de Laboratórios \\
\hline COTEP & Coordenadoria Técnico-Pedagógica \\
\hline CUSC & Centro Universitário São Camilo \\
\hline CUT & Central Única dos Trabalhadores \\
\hline D.E.L.T.A & Documentação de Estudos em Linguística Teórica e Aplicada \\
\hline ECA & Escola de Comunicações e Artes \\
\hline EDIPUCRS & Editora da Pontifícia Universidade Católica do Rio Grande do Sul \\
\hline EDUC & Editora da Pontifícia Universidade Católica de São Paulo \\
\hline EDUFAL & Editora da Universidade Federal de Alagoas \\
\hline EDUFRO & Editora da Universidade Federal de Rondônia \\
\hline EDUFU & Editora da Universidade Federal de Uberlândia \\
\hline EHESS & École des Hautes Études en Sciences Sociales \\
\hline EST & Escola Superior de Teologia \\
\hline FAFIUV & Faculdade Estadual de Filosofia, Ciências e Letras de União da Vitória/PR \\
\hline FALE & $\begin{array}{l}\text { Faculdade de Letras } \\
\end{array}$ \\
\hline FAPEMAT & Fundação de Amparo à Pesquisa do Estado do Mato Grosso \\
\hline FAPEMIG & Fundação de Amparo à Pesquisa do Estado de Minas Gerais \\
\hline FAPERGS & Fundação de Amparo à Pesquisa do Estado do Rio Grande do Sul \\
\hline FAPERJ & Fundação de Amparo à Pesquisa do Estado do Rio de Janeiro \\
\hline
\end{tabular}




\begin{tabular}{|c|c|}
\hline FAPESP & Fundação de Amparo à Pesquisa do Estado de São Paulo \\
\hline FCM & Faculdade de Ciências Médicas \\
\hline FDE & Fundação para o Desenvolvimento da Educação \\
\hline FE & Faculdade de Educação \\
\hline FFC & Faculdade de Filosofia e Ciências \\
\hline FECILCAM & Faculdade de Ciências e Letras de Campos Mourão \\
\hline FFLCH & Faculdade de Filosofia, Letras e Ciências Humanas \\
\hline FIDENE & $\begin{array}{c}\text { Fundação de Integração, Desenvolvimento e Educação do Noroeste do Estado do } \\
\text { Rio Grande do Sul }\end{array}$ \\
\hline FIESP & Federação das Indústrias do Estado de São Paulo \\
\hline FINEP & Financiadora de Estudos e Projetos \\
\hline FNLIJ & Fundação Nacional do Livro Infantil e Juvenil \\
\hline FPCE & Faculdade de Psicologia e de Ciências da Educação \\
\hline FPCEUP & Faculdade de Psicologia e de Ciências da Educação da Universidade do Porto \\
\hline FUNDAMES & $\begin{array}{l}\text { Fundação Missioneira de Ensino Superior } \\
\end{array}$ \\
\hline GEGE & Grupo de Estudos de Gêneros do Discurso \\
\hline GEL & Grupo de Estudos Linguísticos \\
\hline Gphellb & Grupo de Pesquisa "História do ensino de língua e literatura no Brasil" \\
\hline IBILCE & Instituto de Biociências, Letras e Ciências Exatas \\
\hline IEL & Instituto de Estudos da Linguagem \\
\hline IFCH & Instituto de Filosofia e Ciências Humanas \\
\hline INEDD & International Education Doctorade Program \\
\hline INEP & Instituto Nacional de Estudos e Pesquisas Educacionais \\
\hline INES & Instituto Nacional de Educação de Surdos \\
\hline LABJOR & Laboratório de Estudos Avançados em Jornalismo \\
\hline LEIA & Laboratório de Educação e Informática Aplicada \\
\hline MEC & Ministério da Educação \\
\hline NIMEC & Núcleo Interdisciplinar para a Melhoria do Ensino de Ciências \\
\hline NUPEIN & Núcleo de Estudos e Pesquisas da Educação na Pequena Infância \\
\hline $\mathrm{PCN}$ & Parâmetros Curriculares Nacionais \\
\hline PCST & Public Communication of Science and Technology \\
\hline PIPHELLB & Projeto Integrado de Pesquisa "História do ensino de língua e literatura no Brasil" \\
\hline PUC/MG & Pontifícia Universidade Católica de Minas Gerais \\
\hline PUCCAMP & Pontifícia Universidade Católica de Campinas \\
\hline RAE & Revista de Administração de Empresas \\
\hline SAS & Serviço de Apoio ao Servidor \\
\hline SBPC & Sociedade Brasileira para o Progresso da Ciência \\
\hline SEE & Secretaria de Estado da Educação \\
\hline SENAI & Serviço Nacional de Aprendizagem Industrial \\
\hline SME & Secretaria Municipal de Educação \\
\hline SIARQ & Arquivo Central do Sistema de Arquivos \\
\hline STU & Sindicato dos Trabalhadores da UNICAMP \\
\hline UEL & Universidade Estadual de Londrina \\
\hline UEM & Universidade Estadual de Maringá \\
\hline UEMS & Universidade Estadual de Mato Grosso do Sul \\
\hline UESA & União dos Estudantes de Santo Ângelo \\
\hline UESB & Universidade Estadual do Sudoeste da Bahia \\
\hline UFES & Universidade Federal do Espírito Santo \\
\hline UFG & Universidade Federal de Goiás \\
\hline UFGRS & Universidade Federal do Rio Grande do Sul \\
\hline UFJF & Universidade Federal de Juiz de Fora \\
\hline UFMG & Universidade Federal de Minas Gerais \\
\hline UFMS & Universidade Federal do Mato Grosso do Sul \\
\hline
\end{tabular}




\begin{tabular}{|c|c|}
\hline UFMT & Universidade Federal de Mato Grosso \\
\hline UFRJ & Universidade Federal do Rio de Janeiro \\
\hline UFS & Universidade Federal de Sergipe \\
\hline UFSC & Universidade Federal de Santa Catarina \\
\hline UFSM & Universidade Federal de Santa Maria \\
\hline UFTM & Universidade Federal do Triângulo Mineiro \\
\hline UnB & Universidade de Brasília \\
\hline UNEB & Universidade do Estado da Bahia \\
\hline UNEMAT & Universidade Estadual de Mato Grosso \\
\hline UNESCO & Urganização das Nações Unidas para a educação, a ciência e a cultura \\
\hline Unesp & Universidade Estadual Paulista \\
\hline UNICAMP & Universidade Estadual de Campinas \\
\hline UNIEMP & Instituto do Forrum Permanente das Relações Universidade-Empresa \\
\hline UNIFRAN & Universidade de Franca \\
\hline UNIJUÍ & Universidade Regional do Noroeste do Estado do Rio Grande do Sul \\
\hline UNINOVE & Universidade Nove de Julho \\
\hline UNIR & Universidade Federal de Rondônia \\
\hline UNISC & Universidade de Santa Cruz do Sul \\
\hline UNISO & Universidade de Sorocaba \\
\hline UNISUL & Universidade do Sul de Santa Catarina \\
\hline UPF & Universidade de Passo Fundo \\
\hline USP & Universidade de São Paulo \\
\hline
\end{tabular}




\section{SUMÁRIO}

INTRODUÇÃO

1. PESQUISAS HISTÓRICAS SOBRE O ENSINO DE LÍNGUA PORTUGUESA E 26 SOBRE A CONTRIBUIÇÃO DAS IDEIAS LINGUÍSTICAS

2. APRESENTAÇÃO DE J. W. GERALDI 39

2.1 Aspectos biográficos de J. W. Geraldi......................................................................... 40

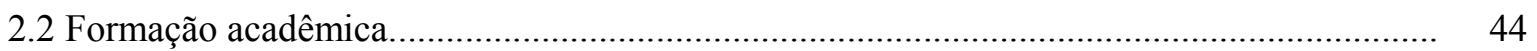

2.2.1 Em instituições do estado do Rio Grande do Sul.......................................................... 44

2.2.2 No IEL/UNICAMP (Campinas-SP)................................................................ 51

2.3 Os orientadores de Geraldi.................................................................................... 57

2.3.1 Carlos Vogt e a perspectiva linguística estruturalista ............................................. 57

2.3.2 Carlos Franchi e a perspectiva linguística gerativa .................................................. 58

3. APRESENTAÇÃO DA BIBLIOGRAFIA DE GERALDI 60

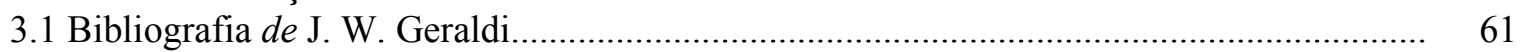

3.1.1 Bibliografia de J. W. Geraldi sobre o ensino de língua portuguesa............................... 87

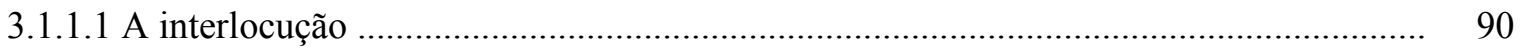

3.1.1.2 O texto como objeto de ensino ...................................................................... 91

3.1.1.2.1 As práticas para o ensino de língua portuguesa ............................................... 91

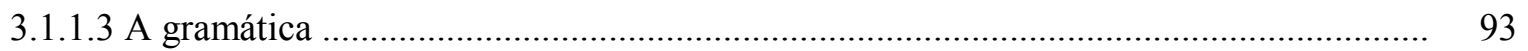

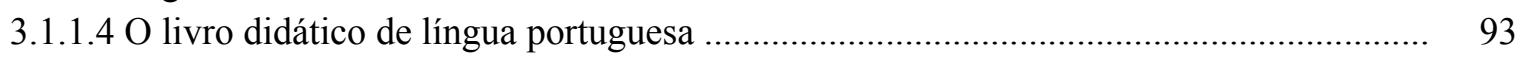

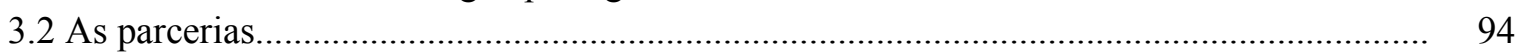

Geraldi.............................................................................. 106

4.1 Bibliografia sobre J. W. Geraldi......................................................................... 107

4.2 Textos sobre a proposta de Geraldi para o ensino de língua portuguesa ......................... 110

5. CONCEPÇÕES TEÓRICAS DO PENSAMENTO DE GERALDI 126

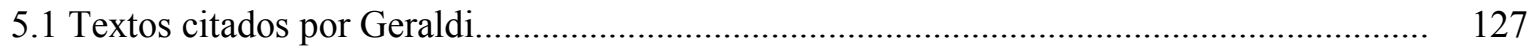

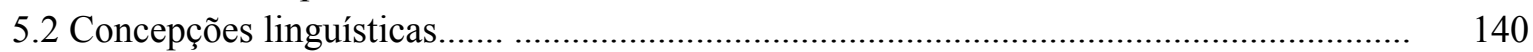

6. CONCEITOS-CHAVE DO PENSAMENTO DE GERALDI SOBRE O ENSINO DE 151 LÍNGUA PORTUGUESA

7. CONTEXTO HISTÓRICO DE PRODUÇÃO DA PROPOSTA DE GERALDI 161 PARA O ENSINO DE LINGUA PORTUGUESA

$\begin{array}{lr}\text { CONSIDERAÇÕES FINAIS } & 171\end{array}$

$\begin{array}{lr}\text { REFERENNCIAS } & 174\end{array}$

APÊNDICE A - Bibliografia de e sobre J. W. Geraldi: um instrumento de pesquisa.......... 186

APENDICE B - Referências de textos mais citados por J. W. Geraldi em textos que 214 tematizam o ensino de língua portuguesa: um instrumento de pesquisa. 
APÊNDICE C - Formação acadêmica de J. W. Geraldi: um instrumento de pesquisa ....... 232 
INTRODUÇÃO 
Após a Graduação em Letras, cursada no Instituto de Biociências, Letras e Ciências Exatas de São José do Rio Preto (IBILCE), da Universidade Estadual Paulista (Unesp) campus de São José do Rio Preto, prestei o mestrado em Educação', cursado entre os anos de 2002 e 2004 junto ao Programa de Pós-Graduação em Educação, da Faculdade de Filosofia e Ciências (FFC), Unesp - campus de Marília, sob orientação da professora Dra . Maria do Rosário Longo Mortatti.

Essa pesquisa esteve vinculada à linha "Ensino de língua portuguesa" do Gphellb², criado em 1994, e do Projeto Integrado de Pesquisa "História do ensino de língua e literatura no Brasil" (Piphellb), em desenvolvimento, em etapas trienais, desde 1995, ambos coordenados pela professora mencionada.

O Gphellb e o Piphellb se organizam em torno de tema geral, método de investigação e objetivo geral que são comuns a todas as pesquisas de seus integrantes. O tema geral se subdivide em cinco linhas de pesquisa: "Formação de professores de língua e literatura", "Alfabetização", "Ensino de língua portuguesa", "Ensino de literatura" e "Literatura infantil e juvenil"; e o método de investigação está centrado em abordagem de fundo histórico, com análise da "configuração textual"3 de fontes documentais.

Dessa pesquisa de mestrado resultou a dissertação intitulada $O$ ensino de língua portuguesa no Brasil, segundo João Wanderley Geraldi (PAULA, 2004a), na qual apresento os resultados da análise da configuração textual da coletânea $O$ texto na sala de aula (1984), organizada por João Wanderley Geraldi, com ênfase nos cinco artigos por ele assinados. Os resultados dessa pesquisa permitiram compreender que a proposta de Geraldi para o ensino de língua portuguesa, baseada no interacionismo lingüístico e contida nessa coletânea, representou uma "revolução conceitual" na história desse ensino em nosso país e, até hoje, influencia significativamente a proposição de políticas públicas e práticas pedagógicas. E em apêndice a essa dissertação, apresentei o instrumento de pesquisa Bibliografia de e sobre João Wanderley Geraldi: um instrumento de pesquisa (PAULA, 2004b), que continha 141 referências de textos de Geraldi, produzidos entre 1978 e 2002, e 17 referências de textos sobre sua obra e atuação profissional, produzidos entre 1981 e 2002.

\footnotetext{
${ }^{1}$ Para o desenvolvimento da pesquisa em nível de mestrado, foi-me concedida bolsa CNPq, de julho de 2002 a agosto de 2004.

${ }^{2}$ Cadastrado no Diretório dos Grupos de Pesquisa no Brasil - CNPq e certificado pela Unesp. Informações disponíveis em http://www.marilia.unesp.br/gphellb.

${ }^{3}$ A expressão "revolução conceitual" foi empregada por Mortatti (1999b), em relação ao pensamento interacionista sobre o ensino de leitura e escrita, representado por Geraldi e pela pesquisadora da Faculdade de Educação (FE) da Universidade Estadual de Campinas (UNICAMP), Ana Luiza Bustamante Smolka, o qual será tematizado adiante, nesta Introdução.
} 
Devido aos objetivos e prazos estabelecidos para o mestrado, porém, não foi possível explorar outros aspectos importantes observados durante o desenvolvimento da pesquisa documental e bibliográfica.

Por essas razões, considerei pertinente e relevante dar continuidade a essa pesquisa, e, para tanto, em março de 2006, ingressei, como doutoranda ${ }^{4}$, no mesmo programa de pósgraduação em Educação e sob a orientação da mesma professora, a fim de desenvolver projeto de pesquisa também vinculado ao Gphellb e ao Piphellb, com o objetivo de compreender as ideias linguísticas constitutivas do pensamento de Geraldi sobre o ensino de língua portuguesa.

Para o desenvolvimento desta tese, especificamente para situá-la no âmbito dos estudos e pesquisas históricas sobre ensino de língua portuguesa no Brasil, realizei leituras de textos básicos, dentre os quais, destaco os de: Soares (1996); Razzini (1992, 2000); Guimarães (1999); Daniel (2001); Di Renzo (2002) e Athayde Junior (2007), cujas sínteses apresentarei no capítulo 1 desta tese.

Consultei também o documento resultante das atividades do Projeto Integrado de Pesquisa "Ensino de Língua e Literatura no Brasil: repertório documental republicano" 5 (MORTATTI, 2003), no qual se encontra reunido "[...] um total de 2025 referências bibliográficas, assim distribuídas entre suas cinco linhas de pesquisa: "Formação de professores de língua e literatura": 211; “Alfabetização": 560; "Ensino de língua portuguesa": 539; “Ensino de literatura": 173; e "Literatura infantil e juvenil”: 542.” (p. 24).

A consulta às referências reunidas na linha de pesquisa "Ensino de língua portuguesa" desse documento, assim como as leituras dos textos mencionados, permitiram constatar, dentre muitos outros aspectos, tanto a importância quanto a escassez de estudos e pesquisas que abordam historicamente o ensino de língua portuguesa, em especial a proposta de Geraldi para esse ensino.

Todas essas leituras e as constatações delas decorrentes contribuíram para confirmar minha opção pela continuidade da pesquisa de mestrado. Por essa razão, elaborei: uma versão atualizada do instrumento de pesquisa iniciado no mestrado, contendo a bibliografia de e sobre João Wanderley Geraldi, intitulado Bibliografia de e sobre J. W. Geraldi: um instrumento de pesquisa (Apêndice A); um segundo instrumento de pesquisa, contendo a relação das referências bibliográficas de textos citados por J. W. Geraldi, intitulado Referências de textos mais citados por J. W. Geraldi em textos que tematizam o ensino de

\footnotetext{
${ }^{4}$ Bolsista CNPq, de dezembro de 2006 a fevereiro de 2010.

${ }^{5}$ Desenvolvido entre 1999 e 2003, com apoio e auxílio CNPq e auxílio FAPESP.
} 
língua portuguesa: um instrumento de pesquisa (Apêndice B) e um terceiro instrumento de pesquisa, intitulado Formação acadêmica de J. W. Geraldi: um instrumento de pesquisa (Apêndice C). Os dois primeiros documentos resultaram de procedimentos de localização, recuperação, reunião, seleção e ordenação dos textos de e sobre Geraldi, produzidos entre 1978, ano do primeiro texto publicado pelo autor, e 2008, ano determinado para o encerramento da recuperação de documentos para a pesquisa de que resultou esta tese. E o terceiro documento resultou de procedimentos de localização, recuperação, reunião, seleção e ordenação de documentos referentes à formação acadêmica de J. W. Geraldi.

A ordenação das referências bibliográficas de textos de e sobre Geraldi se mostrou um importante instrumento para a compreensão de seu pensamento e sua trajetória profissional, desde a década de 1980 até os dias atuais. A ordenação das referências de textos citados por Geraldi em seus textos que tematizam o ensino de língua portuguesa, propiciou constatar, em especial, tanto a acentuada citação por Geraldi de textos de seu orientador de doutorado, Carlos Franchi, da acentuada citação de textos de Mikhail Bakhtin, autor de origem russa que focaliza a linguagem e a literatura em seus textos, assim como a citação de textos de autores das ideias linguísticas de origem francesa, que representam a maior incidência de referências de textos em língua estrangeira citadas por Geraldi.

E a ordenação de documentos referentes à formação acadêmica de Geraldi, por sua vez, permitiu constatar as concepções linguísticas que estavam em voga no momento de sua formação acadêmica e que constituíram o seu pensamento sobre o ensino de língua portuguesa.

A análise preliminar das referências contidas nos textos e no documento propiciou confirmar a relevância e a pertinência do estudo das ideias linguísticas constitutivas do pensamento de Geraldi sobre o ensino de língua portuguesa, somando-se aos meus interesses e preocupações decorrentes de reflexões acerca do ensino de língua portuguesa iniciadas no mestrado. Essa análise preliminar propiciou também estabelecer como corpus para análise na pesquisa de doutorado os três livros nos quais considero estarem sintetizadas e "tematizadas" as ideias linguísticas constitutivas do pensamento de Geraldi: O texto na sala de aula: leitura

\footnotetext{
${ }^{6}$ Utilizo o termo "tematizado" a partir de considerações de Mortatti (2000) quanto a classificações de documentos referentes a "conteúdo, finalidade e forma de veiculação", a saber: "a) tematizações - contidas especialmente em artigos, conferências, relatos de experiências, memórias, livros teóricos e de divulgação, teses acadêmicas, prefácios e instruções de cartilhas e livros de leitura; b) normatizações: contidas em legislação de ensino (leis, decretos, regulamentos, portarias, programas e similares); e c) concretizações: contidas em cartilhas e livros de leitura, 'guias do professor', memórias, relatos de experiências e material produzido por professores e alunos no decorrer das atividades didático-pedagógicas.” (MORTATTI, 2000, p. 29)
} 
\& produção (1984), com ênfase nos cinco artigos de sua autoria, Portos de Passagem (1991) e Linguagem e ensino: exercícios de militância e divulgação (1996)=

Com o objetivo de contribuir para a produção de uma história do ensino de língua portuguesa no Brasil, formulei, então, os seguintes problemas: quais as ideias linguísticas constitutivas do pensamento de Geraldi sobre o ensino de língua portuguesa no Brasil e quais são os "deslocamentos"” dessas ideias linguísticas propostos por Geraldi para o ensino de língua portuguesa?

Para conduzir a pesquisa, formulei a seguinte hipótese: a proposta de Geraldi para o ensino de língua portuguesa, baseada no interacionismo linguístico, sofreu significativa influência principalmente das ideias franchianas sobre o ensino de língua portuguesa, das ideias bakhtinianas sobre linguagem e das ideias linguísticas de origem francesa, veiculadas no Brasil a partir da década de 1980.

Os objetivos definidos para a pesquisa foram, então, os seguintes:

- contribuir para a produção de uma história do ensino de língua e literatura no Brasil, que auxilie na busca de soluções para os problemas desse ensino, no presente;

- localizar, recuperar, reunir, selecionar e ordenar a bibliografia de Geraldi e sobre sua obra e atuação profissional, a fim de contribuir para o desenvolvimento de pesquisas correlatas.

- compreender as ideias linguísticas constitutivas do pensamento de João Wanderley Geraldi sobre ensino de língua portuguesa, por meio da análise da configuração textual dos livros escolhidos como corpus;

- compreender os "deslocamentos" propostos por Geraldi das ideias linguísticas para o ensino de língua portuguesa; e

- $\quad$ contribuir para o desenvolvimento de pesquisas correlatas.

A fim de fundamentar a análise dos três livros do autor escolhidos como corpus para análise na pesquisa de doutorado, e dada a acentuada ocorrência nos textos de Geraldi, foram por mim utilizados determinados conceitos, que podem ser sintetizados por meio dos

\footnotetext{
${ }^{7}$ Utilizo o termo "deslocamento" inspirada nas reflexões de Gregolin (2003). Abordando questões relativas à Análise do Discurso, a autora afirma que: "A análise do discurso desloca-se da primazia sobre o discurso político, sobre a materialidade escrita, para encontrar outras formas materiais, outros regimes de materialidade." (GREGOLIN, 2003, p. 9, grifo meu).
} 
seguintes termos e expressões: "interacionismo lingüístico", “discurso", "linguagem", "história das disciplinas escolares", "pesquisa histórica" e "análise da configuração textual".

Com relação ao conceito de "interacionismo lingüístico", pode ser sintetizado na seguinte formulação de Bakhtin (2002) a respeito do caráter dialógico da enunciação: “[...] a enunciação é o produto da interação de dois indivíduos socialmente organizados e, mesmo que não haja um interlocutor real, este pode ser substituído pelo representante médio do grupo social ao qual pertence o locutor." (BAKHTIN, 2002, p. 112). Para Bakhtin (2002), todo discurso é construído na interação com outros, haja vista que o pensamento se dá em uma relação dialógica com os discursos de outros sujeitos. Sob essa perspectiva,

Essa orientação da palavra em função do interlocutor tem uma importância muito grande. Ela é determinada tanto pelo fato de que procede de alguém, como pelo fato de que se dirige para alguém. Ela constitui justamente o produto da interação do locutor e do ouvinte. Toda palavra serve de expressão de um em relação ao outro. Através da palavra, defino-me em relação ao outro, isto é, em última análise, em relação à coletividade. A palavra é uma espécie de ponte lançada entre mim e os outros. Se ela se apóia sobre mim numa extremidade, na outra apóia-se sobre o meu interlocutor. A palavra é o território comum do locutor e do interlocutor. (BAKHTIN, 2002, p. 113)

Nesse sentido, "A situação social mais imediata e o meio social mais amplo determinam completamente e, por assim dizer, a partir do seu próprio interior, a estrutura da enunciação.” (BAKHTIN, 2002, p. 113)

Sobre o "discurso", para Foucault (2002), há “propriedades singulares" e "papéis preestabelecidos" que determinam o falar do falante. E ainda, segundo Foucault (2002), “Todo sistema de educação é uma maneira política de manter ou de modificar a apropriação dos discursos, com os saberes e os poderes que eles trazem consigo" (FOUCAULT, 2002, p. 44). Para o autor, a partir dessa concepção, o discurso é internalizado pelo sujeito quando representa para ele uma verdade. Assim,

[...] suponho que em toda sociedade a produção do discurso é ao mesmo tempo controlada, selecionada, organizada e redistribuída por certo número de procedimentos que têm por função conjurar seus poderes e perigos, dominar seu acontecimento aleatório, esquivar sua pesada e temível materialidade. (FOUCAULT, 2002, p. 9)

Dessa forma, para Foucault (2002), no discurso não está somente “[...] aquilo que traduz as lutas ou os sistemas de dominação, mas aquilo por que, pelo que se luta, o poder do qual nos queremos apoderar.”(p. 10) 
Para Orlandi (1999a), por sua vez, o conceito de "discurso" "[...] tem em si a idéia de curso, de percurso, de correr por, de movimento. O discurso é, assim, palavra em movimento, prática de linguagem: com o estudo do discurso observa-se o homem falando." (ORLANDI, 1999a, p. 15), e, a partir dessa concepção, o discurso é um objeto sócio-histórico, tendo por pressuposto seu aspecto linguístico.

\begin{abstract}
A Análise do Discurso concebe a linguagem como mediação necessária entre o homem e a realidade natural e social. Essa mediação, que é o discurso, torna possível tanto a permanência e a continuidade quanto o deslocamento e a transformação do homem e da realidade em que ele vive. O trabalho simbólico do discurso está na base da produção da existência humana. (ORLANDI, 1999a, p. 15, grifo meu)
\end{abstract}

Nesse sentido, a partir da concepção de discurso, “[...] procura-se compreender a língua fazendo sentido, enquanto trabalho simbólico, parte do trabalho social geral, constitutivo do homem e da sua história." (ORLANDI, 1999a, p. 15)

Segundo Maingueneau (1997, p. 32), um sujeito, quando enuncia, partilha com seus interlocutores um "ritual social da linguagem", pois "Ao enunciar, eu me concedo um certo lugar e 'atribuo um lugar complementar ao outro'.”. E, a partir dessa concepção de “discurso", para Maingueneau (1997),

Esta instância de subjetividade enunciativa possui duas faces: por um lado, ela constitui o sujeito em sujeito de seu discurso, por outro, ela o assujeita. Se ela submete o enunciador a suas regras, ela igualmente o legitima, atribuindo-lhe a autoridade vinculada institucionalmente a este lugar. Uma tal concepção opõe-se a qualquer concepção "retórica": aquela que coloca dois indivíduos face a face e lhes propõe um repertório de "atitudes", de "estratégias" destinadas a atingir esta ou aquela finalidade consciente. $\mathrm{Na}$ realidade, para a $\mathrm{AD}$, não é possível definir nenhuma exterioridade entre os sujeitos e seus discursos. (MAINGUENEAU, 1997, p. 33)

E ainda, de acordo com Maingueneau (1997, p. 45), "Não basta falar de 'lugares’ ou de 'deixis'; a descrição dos aparelhos não deve levar a esquecer que o discurso é inseparável daquilo que poderíamos designar muito grosseiramente de uma 'voz'."

Quanto à "linguagem", para Benveniste (1995, p. 285-6), por meio dela define-se o homem, pois “Para que a palavra assegure a 'comunicação', é preciso que esteja habilitada a isso pela linguagem, da qual é apenas a atualização." (BENVENISTE, 1995, p. 285-6). Ainda, para o autor, é a partir da linguagem que o homem se torna sujeito, por meio de um contato de um "eu” com um "tu”, numa relação recíproca. Em outras palavras, a linguagem "É tão profundamente marcada pela expressão da subjetividade que nós nos perguntamos se, 
construída de outro modo, poderia ainda funcionar e chamar-se linguagem." (BENVENISTE, 1995, p. 287). Nas palavras de Benveniste (1995),

\begin{abstract}
Não atingimos nunca o homem separado da linguagem e não o vemos nunca inventando-a. Não atingimos jamais o homem reduzido a si mesmo e procurando conceber a existência do outro. É um homem falando que encontramos no mundo, um homem falando com outro homem, e a linguagem ensina a própria definição do homem. (BENVENISTE, 1995, p. 285)
\end{abstract}

Dessa forma, para Benveniste (1995), “A linguagem está de tal forma organizada que permite a cada locutor apropriar-se da língua toda designando-se como eu.” (p. 288)

Segundo Franchi, por sua vez, é positiva uma "ciência da linguagem", e negativa, uma "ciência descritiva das línguas". Sob essa perspectiva, para uma ciência da linguagem, o autor considera essenciais noções correlacionadas com a função da comunicação, a qual "[...] se situa em relação a seu uso social, aberta aos fatores que a condicionam e determinam na interação dos interlocutores, em suas relações com o mundo e a cultura." (1977, p. 10). Ele acrescenta,

Não há nada imanente na linguagem, salvo sua força criadora e constitutiva,
embora certos "cortes" metodológicos e restrições possam mostrar um
quadro estável e constituído. Não há nada universal, salvo o processo - a
forma, a estrutura dessa atividade. A linguagem, pois, não é um dado ou
resultado; mas um trabalho que "dá forma" ao conteúdo variável de nossas
experiências, trabalho de construção, de retificação do "vivido', que ao
mesmo tempo constitui o sistema simbólico mediante o qual se opera sobre a
realidade e constitui a realidade como um sistema de referências em que
aquele se torna significativo. (FRANCHI, 1977, p. 22)

Assim, a linguagem, para Franchi, não é somente “[...] um processo de representação, [...] mas ainda uma prática imaginativa que não se dá em um universo fechado [...], mas permite passar, [...] a diferentes universos mais amplos, atuais, possíveis, imaginários.” (FRANCHI, 1977, p. 23)

Quanto às opções de ordem metodológica para o desenvolvimento da pesquisa, considerando a proposta em abordar historicamente o ensino de língua portuguesa, são necessárias as considerações de Chervel (1990), Santos (1990), Forquin (1992) e Hébrard (2002), a respeito da "história das disciplinas escolares", e as de Mortatti (1999a) e Boto (1994), a respeito da "pesquisa histórica em educação".

Para Chervel (1990), “disciplina escolar” é "[...] aquilo que se ensina e ponto final." (p. 177). Segundo o autor, cabe à sociedade e à cultura a transmissão para os indivíduos dos conteúdos de ensino, e os pedagogos, por sua vez, devem “[...] arranjar os métodos de modo que eles permitam que os alunos assimilem o mais rápido e o melhor possível a maior porção 
possível da ciência de referência." (CHERVEL, 1990, p. 181). Além disso, considera que "Se o papel da escola é o de ensinar e, de um modo geral, o de 'educar', como não ver que a história da função educacional e docente deve constituir o pivô ou o núcleo da história do ensino?” (CHERVEL, 1990, p. 184)

Porque são criações espontâneas e originais do sistema escolar é que as disciplinas merecem um interesse todo particular. E porque o sistema escolar é detentor de um poder criativo insuficientemente valorizado até aqui é que ele desempenha na sociedade um papel o qual não se percebeu que era duplo: de fato ele forma não somente os indivíduos, mas também uma cultura que vem por sua vez penetrar, moldar, modificar a cultura da sociedade global. (CHERVEL, 1990, p. 184)

Com relação à "história das disciplinas escolares", para Hébrard (2002), desde que a formação dos professores dos Ensinos Fundamental e Médio passou a ser incumbência das universidades, “[...] numerosos professores dos Institutos Universitários de Formação dos Professores deslocaram seu interesse pela disciplina na qual foram formados [...] para os problemas colocados hoje pelo ensino da disciplina.” (p. 33). Para ele,

[...] o principal debate nesse domínio refere-se às relações entre saberes eruditos e saberes escolares. Para certos autores (modelo da transposição didática), os sistemas escolares são percebidos como dispositivos que selecionam e transformam os saberes produzidos pelos "intelectuais" com a finalidade de torná-los assimiláveis por jovens alunos. Para outros (modelo da história das disciplinas escolares), a escola constrói seus próprios tipos de saberes ou habilidades conforme os modos de elaboração, cuja lógica pode ser encontrada dentro dos próprios sistemas escolares. É o caso, por exemplo, das gramáticas escolares, que durante muito tempo não se beneficiaram dos avanços da filologia ou das ciências da linguagem e dificilmente aceitaram esse enxerto quando a ocasião se apresentou. (HÉBRARD, 2002, p. 35-36)

Segundo Hébrard (2002), é função da escola formar “[...] em seu espaço próprio, sujeitos que lêem, escrevem, mas também ordenam o mundo conforme as categorias que o corpus dos textos e a palavra do professor tornam quase naturais." (p. 77). E, ainda, a escola “[...] é obrigada a produzir uma recepção compartilhada dos textos, pelo único fato de que, sem a certeza do sentido, não haveria nem ensino possível, nem aprendizagem." (HÉBRARD, 2002, p. 77)

Santos (1990), por sua vez, focaliza "[...] as transformações ocorridas em uma disciplina ao longo do tempo" (p. 21), considerando a identificação dos "[...] fatores mais diretamente relacionados às mudanças de conteúdo e métodos de ensino, o que possibilita a articulação de propostas mais consistentes de alteração ou implementação de mudanças curriculares." (SANTOS, 1990, p. 21). Segundo Santos (1990), as mudanças em uma 
disciplina ou conteúdo escolar "[...] são condicionadas por fatores internos e externos, que devem ser analisados dentro de uma perspectiva sócio-histórica.” (p. 27).

Os primeiros dizem respeito às próprias condições de trabalho na área, e os últimos estão diretamente relacionados à política educacional e ao contexto econômico, social e político que a determinam. A importância, ou o peso atribuído a estes fatores dependerá do nível de desenvolvimento em que se encontra a própria área de estudos, bem como do próprio contexto educacional e do regime político e tradição cultural que o circunscrevem. (SANTOS, 1990, p. 21)

Ainda, para a autora, “[...] o desenvolvimento de uma disciplina deve articular o educacional ao social e lidar com complexas relações existentes entre esses dois níveis.” (p. 27)

Segundo Forquin (1992), é na escola que "[...] circulam fluxos humanos, onde se investem e se gerem riquezas materiais, onde se travam interações sociais e relações de poder; ela é também um local [...] de gestão e de transmissão de saberes e de símbolos." (p. 28). Assim, Forquin (1992) considera que as escolas optam pelos conteúdos que querem ensinar. Dessa forma, "Os docentes podem ter hierarquias de prioridades divergentes, mas todos os docentes e todas as escolas fazem seleções de um tipo ou de outro no interior da cultura." (FORQUIN, 1992, p. 31). Para ele,

[...] a exposição didática, à diferença da exposição teórica, deve levar em conta não apenas o estado do conhecimento mas também o estado do conhecente, os estados do ensinado e do ensinante, sua posição respectiva com relação ao saber e a forma institucionalizada da relação que existe entre um e outro, em tal ou qual contexto social. (FORQUIN, 1992, p. 33)

O autor afirma ainda que a reflexão sobre os saberes escolares tem por função contribuir "[...] para dissolver esta percepção natural das coisas, ao mostrar como os conteúdos e os modos de programação didática dos saberes escolares se inscrevem [...] na configuração de um campo escolar e [...] de um campo social [...].” (FORQUIN, 1992, p. 4344)

Sobre "pesquisa histórica em educação", Mortatti (1999a) a define como um tipo de “[...] pesquisa científica, cuja especificidade consiste, do ponto de vista teórico-metodológico, na abordagem histórica - no tempo — do fenômeno educativo em suas diferentes facetas." (MORTATTI, 1999a, p. 73). Esse tipo de pesquisa, segundo a autora, “[...] demanda a recuperação, reunião, seleção e análise de fontes documentais, como mediadoras na produção do objeto de investigação.” (MORTATTI, 1999a, p. 73). A análise dessas fontes documentais permite ao pesquisador a interpretação de uma determinada época, que resulta na elaboração de um texto escrito pelo pesquisador. E, para Mortatti (1999a), portanto, 
[...] abordar historicamente a educação não significa apresentar uma sucessão de acontecimentos passados, de acordo seja com uma temporalidade linear e ascensional, em direção à culminância do processo histórico no presente, enquanto fim da evolução, seja com a lei do "eterno retorno" ou com a da sucessão de ciclos de apogeu e decadência, ação e reação. Abordar historicamente a educação significa, pelo contrário, buscar apreender e problematizar, por meio de configurações textuais - as lidas e as produzidas pelo pesquisador - , a simultaneidade entre continuidade e descontinuidade de sentidos a respeito do fenômeno educativo em suas diferentes facetas, simultaneidade essa que caracteriza o movimento histórico e as "temporalidades múltiplas" que nele coexistem. (MORTATTI, 1999a, p. 75).

Assim, ao investigador cabe "[...] buscar, mediante a compreensão do passado remoto e recente, o enfrentamento dos problemas do presente fugidio e a construção do futuro desejado.” (MORTATTI, 1999a, p. 75).

Boto (1994), por sua vez, considera o pesquisador da área de história como aquele que “[...] interage com questões intelectuais a serem resolvidas no decurso da pesquisa, hipóteses a propósito do enigma que pretende decifrar." (BOTO, 1994, p. 24). O trabalho historiográfico, por sua vez, situa-se "[...] invariavelmente na confluência entre o tempo do objeto investigado e o tempo do sujeito investigador." (BOTO, 1994, p. 24). Sob essa perspectiva, "[...] compreender o que uma época perguntou a respeito da outra conduz à possibilidade de maior familiaridade com ambas.” (BOTO, 1994, p. 24). E ainda,

[...] a investigação em história ocorre por deslocamentos perante perguntas pelas quais a confraria historiográfica venha a inquirir o passado. Nessa medida, pressupõe-se a existência de paradigmas norteadores da pesquisa em história.

O discurso produzido dialoga, assim, com um conjunto de textos, estruturando, no conjunto, um universo interpretativo capaz de colidir com outros. Na interlocução entre recortes de realidade nem sempre compatíveis, pode-se mesmo chegar a um impasse: sendo distintos os modelos interpretativos, corre-se o risco de efetuar um diálogo de surdos, onde o oponente define-se por aquilo que não é. (BOTO, 1994, p. 30)

Dessa forma, na concepção de Boto (1994), há o “[...] abandono da crença na superioridade do presente e da cultura atual sobre a época e a cultura do objeto investigado. (p. 31)

Quanto à expressão "configuração textual", trata-se de proposta de Magnani (1993)/Mortatti (2000), para nomear o conjunto de aspectos que, inter-relacionados, constituem o sentido de um texto, a saber:

[...] as opções temático-conteudísticas (o quê?) e estruturais formais (como?), projetadas por um determinado sujeito (quem?), que se apresenta como autor de um discurso produzido de determinado ponto de vista e lugar 
social (de onde?) e momento histórico (quando?), movido por certas necessidades (por quê?) e propósitos (para quê?), visando a determinado tipo de leitor (para quem?) e logrando determinado tipo de circulação, utilização e repercussão. (MORTATTI, 2000, p. 31).

Dessa forma, a partir dessa análise, ao investigador é possível: “[...] reconhecer e interrogar determinado texto como configuração "saturada de agoras" e "objeto singular e vigoroso"; e dele produzir uma leitura possível e autorizada [...].” (MORTATTI, 2000, p. 31).

A pesquisa histórica de que resultou esta tese foi, portanto, desenvolvida a partir de procedimento metodológico centrado em pesquisa documental e bibliográfica, mediante procedimentos de: localização, recuperação, reunião, seleção, ordenação e análise de fontes documentais; e de leitura de bibliografia especializada sobre o tema da pesquisa.

Considerei como fontes documentais privilegiadas para análise os artigos de Geraldi contidos na coletânea $O$ texto na sala de aula (1984) e os livros Portos de Passagem (1991a) e Linguagem e ensino: exercícios de militância e divulgação (1996a). Como auxiliares para a análise, utilizei também outros textos de Geraldi e textos produzidos por outros autores que tratam de sua produção escrita e atuação profissional. Essa análise incidiu sobre os aspectos que constituíram o seu sentido, visando à compreensão das ideias linguísticas constitutivas do pensamento de Geraldi sobre ensino de língua portuguesa neles presentes.

Em vista do exposto, optei por organizar esta tese de doutorado da forma apresentada a seguir, a qual está sujeita a alterações, conforme sugestões dos membros dessa Banca Examinadora.

Nesta Introdução, apresento a pesquisa, a partir da exposição de seus antecedentes, o tema, o corpus para análise, os objetivos, a hipótese, as questões que nortearam a investigação, os procedimentos metodológicos e os pressupostos teórico-metodológicos.

No capítulo 1, apresento síntese da bibliografia sobre pesquisas históricas que abordam o ensino de língua portuguesa no Brasil e também síntese da bibliografia sobre pesquisas históricas que abordam a contribuição das ideias linguísticas para o ensino de língua portuguesa, que dialogam diretamente com minha tese.

Os aspectos da biografia de Geraldi, ressaltando sua atuação profissional e formação acadêmica são por mim apresentados no capítulo 2 . 
Os capítulo 3 e 4 tratam, respectivamente, dos aspectos referentes à bibliografia de e sobre Geraldi.

No capítulo 5, apresento os autores cujos textos são mais recorrentes em textos de Geraldi que abordam o ensino de língua portuguesa, assim como as ideias linguísticas que constituíram seu pensamento sobre esse ensino.

No capítulo 6, por sua vez, apresento conceitos-chave do pensamento de Geraldi sobre o ensino de língua portuguesa, com destaque para as concepções de "linguagem", "sujeito" e "discurso/texto" apresentadas por ele nos três livros em que considero estar "tematizado" o seu pensamento sobre o ensino de língua portuguesa.

Quanto aos aspectos referentes ao momento histórico educacional de produção do corpus analisado, os três livros de Geraldi, em especial o " $4^{\circ}$. momento" da história do ensino de leitura e escrita no Brasil, quando ocorreu a "revolução conceitual" no ensino de leitura e escrita em nosso país, são por mim destacados no capítulo 7.

Logo após, apresento as considerações finais sobre a pesquisa que desenvolvi e que resultou em minha tese, seguidas de "Referências" e "Obras de referência citadas".

Seguem-se também três apêndices: o Apêndice A, intitulado Bibliografia de e sobre J. W. Geraldi: um instrumento de pesquisa" (29 f.); o Apêndice B, intitulado Textos mais citados por J. W. Geraldi em textos que tematizam o ensino de língua portuguesa: um instrumento de pesquisa" (16 f.) e o Apêndice C, intitulado Formação acadêmica de J. W. Geraldi: um instrumento de pesquisa $(14 \mathrm{f}) .=$ 
CAPÍTULO 1

PESQUISAS HISTÓRICAS SOBRE O ENSINO DE LÍNGUA PORTUGUESA E SOBRE A CONTRIBUIÇÃO DAS IDEIAS LINGUÍSTICAS 
Somente a partir do final do século XX e no século XXI, as pesquisas históricas sobre o ensino de leitura e escrita começaram a se intensificar, de acordo com estudos de Mortatti (2003).

Conforme consulta ao documento resultante das atividades do Projeto Integrado de Pesquisa "Ensino de Língua e Literatura no Brasil: repertório documental republicano" (MORTATTI, 2003), anteriormente apresentado na Introdução desta tese, de um total de 2025 referências de textos produzidos por brasileiros até o ano de 2002, 539 referências se referem ao ensino de língua portuguesa. Mortatti (2003) conclui, a partir da pesquisa realizada, que as pesquisas sobre esse ensino estão aumentando, mas são ainda escassas as com abordagem histórica sobre o ensino de língua portuguesa.

No entanto, apesar de se apresentarem em número reduzido, alguns textos contribuem para a melhor compreensão da história do ensino de língua portuguesa, a saber, os de: Soares (1996); Razzini (1992, 2000); Guimarães (1999); Daniel (2001); Di Renzo (2002); e Athayde Junior (2007). Esses textos, de autoria de escritores brasileiros, focalizam desde o início da colonização brasileira até a década de 1980, quando as ciências linguísticas, de maneira prioritária nesse momento, passaram a influenciar a história desse ensino em nosso país.

Soares (1996), no texto "Português na escola: história de uma disciplina curricular", publicado na Revista de educação $A E C$, destaca o período em que a língua portuguesa foi “incluída como componente curricular" no currículo secundário das escolas no Brasil: "no final do Império, com a criação do Colégio Pedro II, no Rio de Janeiro". Abordando esse tema desde o momento da colonização do Brasil por Portugal, a autora considera as três línguas que eram aqui faladas: “[...] ao lado do português trazido pelo colonizador, codificouse uma língua geral, que recobria as línguas indígenas faladas no território brasileiro [...], o latim era a terceira língua, [...]” (p. 11). Segundo Soares (1996), no momento de colonização, o português era apenas "instrumento para a alfabetização" (p.12). Somente mais tarde, nos anos 50 do século XVII, o Marquês de Pombal implantou reformas, dentre as quais a Reforma Pombalina, tanto no ensino de Portugal quanto no de suas colônias, por meio da qual os jesuítas são expulsos de todo o território português e de suas colônias, incluindo o Brasil, tendo se tornado obrigatório o ensino da língua portuguesa em nosso país. A partir de então, a "língua geral”, falada pelos indígenas brasileiros, foi proibida.

Somente nas últimas décadas do século XIX, no final do Império, a disciplina língua portuguesa foi incluída no currículo escolar, contribuindo, assim, para a instituição do ensino da língua portuguesa nas escolas brasileiras. E, ainda segundo Soares (1996), a partir dos anos 1950 
[...] começa a ocorrer uma real modificação no conteúdo da disciplina português. E isso se dá porque uma progressiva transformação das condições sociais e culturais e, sobretudo, das possibilidades de acesso à escola vai exigindo a reformulação das funções e dos objetivos dessa instituição, o que acarreta, entre outras alterações, mudanças nas disciplinas curriculares. [...] é a partir desse momento que começa a modificar-se profundamente o alunado: como consequência da crescente reivindicação, pelas camadas populares, do direito à escolarização, democratiza-se a escola, e já não são apenas os "filhos-família", os filhos da burguesia, que povoam as salas de aula, são também os filhos dos trabalhadores - nos anos 60 , o número de alunos no ensino médio quase triplicou, e duplicou no ensino primário. [...] como consequência da multiplicação de alunos, ocorreu um recrutamento mais amplo e, portanto, menos seletivo de professores, embora estes fossem já, em grande parte, oriundos das recémcriadas Faculdades de Filosofia, formados não só em conteúdos de língua e de literatura, mas também de pedagogia e didática. (p. 16-17)

Dessa forma, tendo em vista essas mudanças sociais e culturais ocorridas em toda a sociedade e, consequentemente, nas escolas, naquele momento (década de 1950), “[...] gramática e texto, estudo sobre a língua e estudo da língua, começam a constituir realmente uma disciplina como um conteúdo articulado" (SOARES, 1996, p. 17). No entanto, nesse período (década de 1950), nos livros didáticos, “[...] estão graficamente separados, a gramática apresentada numa metade do livro, os textos na outra metade" (SOARES, 1996, p. 17).

No capítulo "Português na escola: história de uma disciplina curricular", publicado em 2002, no livro Lingüística da norma, organizado por Marcos Bagno ${ }^{8}$, Soares também aborda as disciplinas retórica, poética e gramática e a tradição delas na disciplina língua portuguesa, destacando o uso das coletâneas de textos como manuais de ensino.

No entanto, segundo Soares (1996), a partir dos estudos sobre a "teoria da comunicação", nos anos 1970, a língua passou a ser compreendida como instrumento de comunicação e a ter desenvolvido o seu ensino não mais em um estudo "sobre" a língua ou um estudo "da" língua, mas sim, a partir de um desenvolvimento do "uso" dessa língua. E, a partir dessa concepção, no ensino da gramática passou-se a propor uma reflexão sobre a língua.

\footnotetext{
${ }^{8}$ O capítulo de livro de Soares, "Português na escola: história de uma disciplina curricular", publicado em 2002 no livro Lingüistica da norma, organizado por Marcos Bagno, foi publicado originalmente, em 1996, na Revista de Educação $A E C$, sob o mesmo título. Com relação às alterações entre os textos, há somente o acréscimo de conteúdo referente às disciplinas.

${ }^{9}$ Sobre essa teoria, segundo Soares (1996, p. 20), ela "[...] surge nos anos 1970, como quadro referencial para a análise da língua, transposta da área dos meios eletrônicos de comunicação [...]." A partir daí, "A concepção de língua como sistema, prevalente até então no ensino da gramática, e a concepção da língua como expressão estética, prevalente inicialmente no ensino da retórica e da poética e, posteriormente, no estudo de textos, são substituídas pela concepção de língua como comunicação." (SOARES, 1996, 20).
} 
Nos anos 1980, as diferentes vertentes das ciências linguísticas tiveram uma grande contribuição para o ensino de português e,

Talvez essa contribuição das ciências lingüísticas ao ensino de português seja a característica fundamental que a disciplina Português assume a partir dos anos 80. Introduzidas nos currículos de formação de professores a partir dos anos 60 - inicialmente, a Lingüistica, mais tarde, a Sociolingüística, ainda mais recentemente, a Psicolingüistica, a Lingüistica Textual, a Pragmática, a Análise do Discurso — só nos anos 80 essas ciências chegam à escola, "aplicadas ao ensino da língua materna". (SOARES, 1996, p. 20)

Na dissertação de mestrado intitulada Antologia nacional (1985-1969): museu literário ou doutrina?, defendida no IEL/UNICAMP, sob a orientação de Marisa Philbert Lajolo, Razzini (1992) contribui para a história do ensino de língua portuguesa, analisando a Antologia nacional, de Fausto Barreto e Carlos de Laet. Para ela, essa Antologia foi

[...] sucesso por mais de 70 anos ao longo de 43 edições, foi uma das compilações literárias mais lidas pela mocidade brasileira que passou pela escola secundária, por várias gerações: adotada oficialmente nos principais colégios do país, teve carreira excepcional, sucesso de público sem precedentes, enquanto as minguadas edições brasileiras, não-didáticas, demoravam anos e anos para vender. (RAZZINI, 1992, p. 7)

Segundo Razzini (1992), com relação às cinco primeiras décadas do século XX, conviveram nas escolas, como "manuais de ensino da disciplina língua portuguesa", as gramáticas e as coletâneas de textos. Sobre a coletânea Antologia Nacional, Razzini (1992) comenta: "[...] apesar de ser um livro didático de orientação imperial e católica, conseguiu sobreviver mais de setenta anos no ensino de orientação republicana” (p. 17) e “[...] o conservadorismo do ensino da língua materna, sempre preso à poética, oratória e retórica clássicas, sobreviveu até recentemente (a última edição da Antologia é de 1969)” (p. 31).

Tendo analisado as mudanças ocorridas nas diversas edições de Antologia nacional, Razzini (1992) constata a sua importância na "consolidação da nacionalidade brasileira",

[...] pela afirmação da literatura brasileira, quer através do progressivo aumento de autores brasileiros, quer através da seqüência escolhida (inversão cronológica) para apresentação dos autores e textos, quer ainda através do tema privilegiado nos trechos compilados, que davam preferência aos excertos que tematizassem o Brasil, repetindo trechos que se tornaram mitos da nossa nacionalidade. (RAZZINI, 1992, p. 118)

Dando continuidade às reflexões do mestrado, em sua tese de doutorado, $O$ espelho $d a$ nação: a Antologia nacional e o ensino de português e de literatura (1838-1971), também defendida no IEL/UNICAMP, sob a orientação da mesma professora, Razzini (2000) 
procurou compreender Antologia nacional, de Fausto Barreto e Carlos de Laet, tendo por referência os programas de ensino do Colégio Pedro II e a legislação então vigente, destacando a história do ensino de Português e de Literatura na escola secundária do Brasil, que teve "[...] O movimento de ascensão [...] acompanhado do declínio do ensino clássico, o qual, no entanto, resistiu até meados do século XX" (RAZZINI, 2000, p. 237).

[...] até 1869, o ensino de Português era insignificante no currículo da escola secundária, onde predominavam as disciplinas clássicas, sobretudo o Latim. Depois de 1869, quando o exame de Português foi incluído entre os Preparatórios de muitos cursos superiores (faculdades de Direito, faculdades de Medicina, Escola Politécnica, Escola de Minas, etc), no Colégio Pedro II houve a ascensão desta disciplina, cujo desenvolvimento, ainda que sujeito a variações, foi sempre crescente. (RAZZINI, 2000, p. 237)

Segundo Razzini (2000), foi a legislação de 1971 que propiciou que os textos literários fossem substituídos por diversos textos de diferentes origens, os quais tinham por objetivo transmitir a "[...] eficácia da comunicação e a compreensão da 'Cultura Brasileira', sucateando a Antologia Nacional, até então difusora e reprodutora da 'vernaculidade' brasilusa" (p. 13). Dessa forma,

$\mathrm{Na}$ escola secundária brasileira dos anos de 1970, o abandono do latim e o enfraquecimento da leitura literária clássica, de orientação lusitana, condenou a adoção de compêndios como a Antologia Nacional, já então, detentora de modelos desgastados, que não mais correspondiam à imagem desejada de nação. Por outro lado, a promoção da leitura de textos contemporâneos beneficiou não só a literatura brasileira moderna, como a entrada dos autores vivos na escola, mas forçou também a revisão de todos os períodos da literatura brasileira, cuja carreira solo entrava, daí em diante, em franco desenvolvimento no curso secundário. (RAZZINI, 2000, p. 245)

Guimarães (1999), por sua vez, no texto “O ensino de língua portuguesa na memória da escola brasileira: aspectos da história de uma disciplina", publicado no livro Estudos sobre o ensino da língua portuguesa, organizado por Eberhard Gärtner, Christine Hundt e Schönberger, apresenta a "projeção da língua materna no campo didático", a qual, segundo essa pesquisadora, “[...] harmoniza-se com a trajetória do ensino da língua materna na escola brasileira". Guimarães (1999) focaliza as ideias interligadas no "enunciado língua/memória/escola”, entendendo o ensino da língua materna como “[...] trabalho coletivo, histórico, que constrói”. Para tanto, analisa os “acervos legislativos": Reforma Capanema ${ }^{10}$,

${ }^{10}$ A Reforma Capanema corresponde às transformações projetadas no sistema educacional brasileiro, em 1942, durante a Era Vargas, pelo ministro da Educação e Saúde, da época, Gustavo Capanema, principalmente no ensino secundário e universitário. O ministro tinha por lema "a educação a serviço da nação" (ARANHA, 1996). 
Lei Federal n. 4024/61 ${ }^{11}$, Lei Federal n. 5692/71 ${ }^{12}$, Guias Curriculares de São Paulo "Propostas para as matérias do Núcleo Comum do Ensino do $1^{\circ}$. grau", Documento Federal n. $91372^{13}$ e também "traços de natureza didático-pedagógicos", como eventos e atividades: I Encontro de Orientadores de Classes Especiais em São Paulo, I Encontro de Mestres, Programa Escola - Biblioteca, obras, autores e atividades diversas. Com relação aos Guias Curriculares de São Paulo, Guimarães (1999) afirma que seus objetivos são repetidos em diferentes séries:

a) ao expressar-se oralmente - objetiva-se que o aluno se expresse em pensamentos completos e claros, com seqüência, com vocabulário adequado, entre outros requisitos.

b) ao ouvir - objetiva-se que o aluno reproduza, identifique os participantes do discurso, identifique novos tipos de frases geradas por transformações, bem como identifique estruturas diversas em diferentes registros.

c) ao ler - objetiva-se que o aluno seja capaz de selecionar idéias essenciais e idéias secundárias ao texto — daí colhendo dados para interpretá-lo com exatidão e profundidade.

d) ao escrever - objetiva-se que o aluno expresse pensamentos marcados por lógica e organicidade, vazados em vocabulário e construções adequadas. (p. 18)

Para Guimarães (1999), a partir da análise dos acervos legislativos e dos eventos e atividades de natureza pedagógica, foi possível compreender

[...] que a grande mudança não virá, por certo, nem dos órgãos oficiais do ensino nem dos projetos de lingüistas e pedagogos, ainda que sejam instâncias e autoridades de quem se espera apoio e estímulo. A verdadeira mudança, porém, virá antes daqueles que vivem a realidade do ensino; não daqueles que especulam sobre ela. (p. 25)

Daniel (2001), na tese de doutorado intitulada $O$ ensino de português na Escola Normal e Modelo Anexa, de Campo Grande: 1930-1940, defendida na USP, sob a orientação de José Luiz Fiorin, para a análise da história da disciplina Língua Portuguesa na primeira fase de funcionamento da Escola Normal e Escola Modelo Anexa, de Campo Grande-MS, na década de 1930, considera decretos, discursos e diários oficiais, jornais da época, artigos,

\footnotetext{
${ }^{11}$ A Lei de Diretrizes e Bases da Educação Nacional, promulgada em 1961, quebra a rigidez do sistema, permitindo a mobilidade entre os cursos, com um secundário menos enciclopédico, possibilitando a redução do número de disciplinas. Outras mudanças dizem respeito à pluralidade de currículos em território federal, assim como a garantia de igualdade de tratamento do Poder Público aos estabelecimentos oficiais e particulares (ARANHA, 1996).

${ }^{12}$ Essa lei da educação brasileira reestruturou o ensino, ampliando a obrigatoriedade de quatro para oito anos, pois o primário, conforme nomenclatura da época, une-se ao ginasial, para tanto, findando o exame de admissão, que selecionava os alunos para o ginásio, deixando à margem os alunos das classes menos favorecidas. Outras mudanças provenientes também dessa lei são a criação da escola única profissionalizante e a reestruturação do supletivo (ARANHA, 1996).

${ }^{13}$ O Decreto Federal $n^{\circ} .91372$, de 26 de junho de 1985, propôs diretrizes para o reexame dos processos de ensino-aprendizagem da língua portuguesa (ARANHA, 1996).
} 
cadernos antigos, dissertações, teses, enciclopédias, dicionários e livros de registros pertencentes ao acervo documental da Escola Normal e Modelo Anexa, assim como as matérias lecionadas, atas, diplomas, expedientes e também cinco livros didáticos de Português ${ }^{14}$ utilizados na época. Daniel (2001) se propõe a compreender os objetivos do ensino dessa disciplina e as relações entre os conteúdos dos livros analisados e a matéria lecionada nas aulas dessas escolas:

[...] há no português escolar um aspecto educacional, integrado ao conjunto dos objetivos, e um aspecto instrucional, que abrange uma parte deles. Portanto, um conteúdo de instrução é posto a serviço de uma finalidade educativa. (DANIEL, 2001, p. 47)

Dessa forma, foi possível para Daniel (2001) constatar que “[...] a sistematização dos conteúdos dos cinco livros didáticos de Português constantes do corpus era feita de acordo com os objetivos legais do ensino da disciplina" (p. 295, grifos da autora), e que o ensino

[...] também era orientado, tal como nos compêndios destinados a esse ensino e a esse nível, no sentido de promover o domínio das regras gramaticais da norma culta, na modalidade escrita, e o conhecimento da história da língua, a partir de textos concebidos como modelos tanto de língua quanto de comportamento. (p. 111)

Di Renzo (2002), no capítulo de livro "Liceu Cuiabano: língua nacional, religião e estado", publicado no livro Institucionalização dos estudos da linguagem: a disciplinarização das idéias lingüísticas, organizado por Orlandi e Guimarães, analisa a "instituição da língua nacional e o surgimento dos grandes colégios no Brasil", tendo por objetivo “[...] (re)construir a história da constituição do saber metalingüístico sobre a língua portuguesa, a partir de uma posição histórica que considera os processos de produção de conhecimentos sobre ela (p. 102)".

A língua nacional é elemento fundamental da construção da idéia de Nação. E, justamente, pela idéia de Nação, tem-se a construção da cidadania que, por sua vez, se dá por processos de identificação. Logo, pode-se dizer que a questão da língua afeta necessariamente as relações com o Estado e viceversa, produzindo sujeitos e políticas que procuram, cada vez mais, legitimálo, visando a construção da unidade em um determinado modelo de sociedade. (DI RENZO, 2002, p. 101)

\footnotetext{
${ }^{14}$ Trata-se dos seguintes livros: 1. PEREIRA, Carlos Eduardo. Gramática expositiva: curso superior. 46. ed. São Paulo: Ed. Nacional, 1926. 390 p. ; 2. MOTA, Otoniel. Lições de português. 9. ed. São Paulo: Cia. Ed. Nacional, 1941. 359 p.; 3. MOTA, Otoniel. O meu idioma. 5. ed. São Paulo: Cia. Ed. Nacional, 1929. 248 p.; 4. NOGUEIRA, Júlio. O exame de português. 4. ed. Rio de Janeiro: Livraria Editora Freitas Bastos, 1930, 365 p. 5. ; BARRETO, Fausto; LAET, Carlos de. Antologia nacional. 32. ed. Rio de Janeiro: Livraria Francisco Alves, $1955.592 \mathrm{p}$.
} 
A partir de análise das políticas e programas elaborados para o ensino da língua, regimentos escolares, gramáticas, dicionários, materiais didáticos, formas de avaliação e currículos, com o intuito de compreender como a prática da língua ocorria, desde 1879, quando foi criado o Liceu Cuiabano, a autora conclui que o ensino da língua nacional envolvia "leitura, escrita e elementos de gramática da língua nacional".

Assim, o português do Brasil, mesmo dentro de uma universalidade, possui variedades que tornam opacos os limites e fronteiras da língua: entre o universal/nacional e aspectos regionais. Indistinção que tem a ver com o caráter jurídico do Estado brasileiro, isto é, um Estado de Direito, idéia de universalidade (inerente ao Estado) que faz funcionar, justamente, esse imaginário da língua nacional. (DI RENZO, 2002, p. 119-120)

O artigo de Athayde Júnior (2007), intitulado “Articular vozes. Deslocar sentidos: o discurso de língua portuguesa em discursos oficiais e em falas de professores”, publicado no periódico Síntese, representa também uma contribuição para a história do ensino de língua portuguesa. Nesse artigo, o autor focaliza

[...] documentos oficiais de propostas curriculares de língua portuguesa produzidos no estado do Paraná na década de 1980 e um conjunto de fragmentos de intervenções de professores desta área do conhecimento durante eventos de formação em serviço ocorridos nos anos 2000 na região oeste daquele estado. (ATHAYDE JÚNIOR, 2007, p. 55)

Quanto aos documentos oficiais analisados pelo autor, são os seguintes: Língua: mundo, mundo, vasto mundo (1987); Conteúdos essenciais do ensino de $2^{\circ}$ grau: Língua Portuguesa (1988) e Currículo Básico para a Escola Pública do Paraná: Língua Portuguesa (1990). Para a análise, Athayde Júnior considera as ações de diferentes sujeitos, tomando-as em projetos no decorrer de 20 anos, ao longo dos quais compreende as bases distintas das propostas paranaenses, mas também o "[...] deslocamento de discursos - e de sentidos" (ATHAYDE JÚNIOR, 2007, p. 58) que culminam com os Parâmetros Curriculares Nacionais (PCN). A respeito dos PCNs, para Athayde Júnior (2007), esses parâmetros se apresentam como "possibilidade" nos anos 1980, como "proposta" no início dos anos 1990 e como "parâmetro" em meados dos anos 1990. Segundo esse autor, o discurso sobre o ensino de língua portuguesa representa um "lugar de construção contínua de provisoriedades".

E aí, entre as vozes que fundam os dizeres dos professores, prevalece a tradição e o sentimento de uma certa impotência para construir o que o discurso novo propõe: por prudência profissional, por incapacidade de risco e mesmo por falta de conhecimentos sobre a linguagem. Em muitos casos, ainda distante da aposta que firmamos nos anos 1980, a postura dos professores - mesmo quando abertos a reconsiderações e a questionamentos de concepções antigas de ensino e aprendizagem - é a de esperar por um novo "modelo" para ser colocado no lugar da tradição. Entretanto, em um número crescente de vezes, este discurso da tradição já aparece como 
"aquele a que há que se opor", mas sem que isso signifique apagá-lo da história, fazê-lo não existir. (ATHAYDE JÚNIOR, 2007, p. 62)

Assim como os textos que abordam historicamente o ensino de língua portuguesa no Brasil, são escassos também os textos que abordam historicamente a contribuição das ideias linguísticas para o ensino de língua portuguesa em nosso país, a saber os de: Geraldi, Silva e Fiad (1996); Orlandi e Guimarães (2001); Souza (2001); Lagazzi-Rodrigues (2002); e Geraldi (2004a) abordam essa temática.

No final da década de 1970 e início da década de 1980, dentre outras áreas de estudo e pesquisas, as ciências linguísticas, de acordo com Geraldi, Silva e Fiad (1996), em "Lingüística, ensino de língua materna e formação de professores", texto publicado no periódico D.E.L.T.A, representaram uma grande contribuição para o ensino de língua portuguesa, oferecendo, entre outras, uma nova concepção de língua. Esse texto resultou da análise de 14 documentos oficiais ${ }^{15}$, produzidos em diferentes estados brasileiros — São Paulo, Paraná, Santa Catarina, Rio Grande do Sul, Rio de Janeiro, Minas Gerais, Mato Grosso do Sul — e Distrito Federal, entre meados da década de 1980 até o início da década de 1990, no momento em que ocorria o processo de redemocratização política, o qual exigia uma nova concepção de ensino nas escolas brasileiras.

[...] a Lingüística somente é incorporada à grade curricular dos cursos de Letras na segunda metade da década de 50 . O esforço inicial, obviamente foi a própria "implantação" da disciplina, que não se fez, sem alguns traumas: não havia lingüistas em número suficiente para constituir o corpo docente; os horizontes que norteavam os estudos da linguagem eram outros, de modo especial a idéia de uma correção lingüística de preferência nos moldes dos escritores bem sucedidos; as variedades lingüísticas eram vistas ora como desvio, ora como curiosidade: havia uma tradição estabelecida de estudos filológicos, literários e estilísticos, não sem inúmeras polêmicas a propósito da "boa e correta expressão". (GERALDI; SILVA E FIAD, 1996, p. 307)

\footnotetext{
${ }^{15}$ São os seguintes os documentos analisados por Geraldi, Silva e Fiad (1996): Proposta curricular para o ensino de língua portuguesa $-1^{\circ}$. grau (São Paulo/1986), Programa de $1^{\circ}$. grau. Língua Portuguesa (São Paulo, 1985), Programa de primeiro grau - ensino regular (São Paulo/1986), Currículo básico (Paraná/1991), Língua: articuladora de visões de mundo (Paraná/1987), Currículo básico para a escola pública do estado do Paraná (Paraná/1992), Língua: mundo, mundo, vasto mundo (Paraná/1987), Relatório final: comissão nacional para o estabelecimento de diretrizes que promovam o aperfeiçoamento do ensino/aprendizagem da língua portuguesa (Brasília/1986), Uma contribuição para a escola pública do pré-escolar, $1^{\circ}$. grau, $2^{\circ}$. grau e Educação de adultos (Santa Catarina/1991), Educação para crescer: projeto de melhoria da qualidade de ensino. Português $-1^{\circ}$. e $2^{\circ}$. graus (Porto Alegre/1991-1995), Fundamentos para elaboração do currículo básico das escolas públicas do município do Rio de Janeiro (Rio de Janeiro/1991), Programa de língua portuguesa e literatura: $1^{\circ}$. e $2^{\circ}$. graus (Minas Gerais/1987), Conteúdos básicos: ciclo básico de alfabetização à $4^{\mathrm{a}}$. série do Ensino Fundamental (Minas Gerais/1993), Diretrizes gerais para o ensino de pré-escolar e de $1^{\circ}$. grau (Mato Grosso do Sul, 1989).
} 
No estado de São Paulo, a Coordenadoria de Estudos e Normas Pedagógicas (CENP) da Secretaria de Estado da Educação (SEE) solicitou “[...] a professores universitários a organização de uma coleção (foram oito volumes) como subsídios para a implantação de novo plano curricular no ensino de segundo grau" (GERALDI; SILVA; FIAD, 1996, p. 309). Nesses documentos, são analisadas pelos autores as concepções de linguagem e de texto que se apresentavam, assim como a importância do papel social da linguagem e da proposta de uma nova organização para o ensino de língua portuguesa:

Os documentos analisados geralmente encerram-se com uma proposta de organização das aulas de português que reflita a priorização atribuída ao texto, e o entendimento da linguagem como forma de interação. $\mathrm{Na}$ realidade, este encaminhamento metodológico, que, na maioria dos textos é delineado de forma a possibilitar ao professor uma organização pessoal, aponta em uma direção que tenta substituir a organização tradicionalmente existente e que está presente nos livros didáticos de português - leitura, gramática e redação. Os documentos enfatizam que o ensino se organizará em práticas, e não em uma lista de conteúdos. (GERALDI; SILVA; FIAD, 1996, p. 322)

Também sobre a contribuição das ideias linguísticas para o ensino de língua portuguesa no Brasil, é representativo o estudo de Orlandi e Guimarães (2001), publicado no texto "Formação de um espaço de produção lingüística: a gramática no Brasil", no livro História das idéias lingüísticas: construção do saber metalingüístico e constituição da língua nacional, organizado por Orlandi. Para os autores, a língua nacional

[...] está ligada aqui ao processo de gramatização brasileira do português que é posto em curso a partir da segunda metade do século XIX. Desde então o Brasil tem seus próprios instrumentos lingüísticos de gramatização, diferentes dos de Portugal. (ORLANDI; GUIMARÃES, 2001, p. 24)

Dessa forma, o processo de gramatização, tal como abordado por Orlandi e Guimarães (2001), contempla, nos títulos das gramáticas e no desenvolvimento de estudos gramaticais, tanto o processo de gramatização por que passava, quanto a distinção das línguas dos dois países.

No Brasil, no final do século XIX, o projeto de uma gramática brasileira do português é não somente pelos gramáticos fiéis à tradição da gramática filosófica mas sobretudo pelos filólogos vindos da filiação à gramática histórico-comparativa. Estes gramáticos produzem, a partir deste momento, um conhecimento da língua que será substituído pouco a pouco pelo estudo da lingüística. Esta mudança se acentua a partir dos anos 1950 quando o estruturalismo de Mattoso Câmara abre o caminho para a gramática descritiva (cf. seu Estrutura da Língua Portuguesa, 1970). E é então que a NGB é instituída, acontecimento que marca uma mudança fundamental na normalização da língua no Brasil. A homogeneização da terminologia atinge também as discussões dos gramáticos. A questão da língua não é mais só da 
competência do gramático, ela torna-se uma questão dos lingüistas. Desde então, a Lingüística intervém na produção das gramáticas do português no Brasil [...]. (ORLANDI; GUIMARÃES, 2001, p. 36-37)

Segundo Souza (2001), em “Às margens da gramática, a emergência da semântica no Brasil", também publicado no livro História das idéias lingüisticas: construção do saber metalingüístico e constituição da língua nacional, organizado por Orlandi, referindo-se à semântica, foi “[...] no interior de gramáticas escolares do final do século XIX (Guimarães, 2000) que esse novo ramo das ciências lingüísticas ganhou destaque" (SOUZA, 2001, p. 125).

Dessa forma, quem examina as gramáticas de autores como Maximino Maciel, Pacheco da Silva Junior, Ernesto Carneiro Ribeiro observa que a semântica que entra na composição dessas gramáticas inscreve-se em um movimento localizado sobretudo na França, aquele que insiste sobre a consideração do sentido como objeto das ciências da linguagem. Trata-se das proposições em torno das leis de mudança semântica, no âmbito das quais a significação adquire um estatuto de legitimação científica, até então só admitido para a dimensão fonética da linguagem (Auroux, 1979). (SOUZA, 2001, p. 125)

As gramáticas, para Souza (2001), participaram da história do ensino de língua portuguesa em nosso país, confirmando a proposta de Auroux (1994 apud SOUZA, 2001) de que "[...] o processo de gramatização das línguas possibilitou espaço para a constituição das ciências lingüísticas ". O autor ainda avalia que

[...] os quadros institucionais que suportam as condições de enunciação podem delinear, em torno do objeto urdido no espaço da gramática, um ponto de heterogeneidade em que as posições de sujeito do gramático deslocam-se entre dois pólos enunciativos: que derivam a gramática simultaneamente como um conjunto de exemplos e regras do bem falar e um trabalho científico sobre a língua. (SOUZA, 2001, p. 136)

Também sobre a contribuição das ideias linguísticas para o ensino de língua portuguesa, Lagazzi-Rodrigues (2002), no capítulo “A língua portuguesa no processo de institucionalização da lingüística", publicado no livro Institucionalização dos estudos da linguagem: a disciplinarização das idéias lingüísticas, organizado por Orlandi e Guimarães, analisa os livros Princípios de Lingüística Geral e História e Estrutura da Língua Portuguesa, de Joaquim Mattoso Câmara Jr. E, sob essa perspectiva, para a autora, "Falar da Lingüística é falar de um saber sobre a língua, científico, institucionalizado e legitimado" (LAGAZZI-RODRIGUES, 2002, p. 13). Além disso,-

[...] o lugar da descrição científica vai constituir a posição de lingüista, em oposição à de gramático normativo. Sobre isso, Orlandi (2000) afirma que na passagem da autoria do lugar do gramático para o lugar de lingüista "a questão posta pela língua migra de uma posição diretamente política e 
intelectual para tornar-se cada vez mais uma questão explicitamente científica. Apesar do apagamento do lugar da autoria na gramática, esta continua, mostra Orlandi, agora como "imposição escolar de uma norma lingüística gramatical", "a produzir efeitos sobre o conhecimento da língua ao lado do saber lingüístico e de sua metalinguagem". (p. 13-14)

Dessa forma, segundo a autora, as questões relacionadas à linguagem são responsáveis pela consolidação da gramática normativa e da linguística brasileira, e "[...] configuram uma materialidade lingüístico-histórica importante para, na história das idéias lingüísticas no Brasil, compreendermos a institucionalização da Lingüística" (LAGAZZI-RODRIGUES, 2002, p. 15).

O sentido de língua portuguesa como evidência de um espaço estrutural de descrição da análise, consolidado pelo trabalho de Mattoso Câmara, foi fundamental para a legitimação científico-institucional da Lingüística no Brasil e para o reconhecimento dos estudos lingüísticos. Eu diria, ampliando essa compreensão, que a língua portuguesa fica significada como a própria instituição científica que possibilita a Lingüística e os estudos lingüísticos no Brasil. Uma legitimação no campo da ciência que se faz necessariamente pela institucionalização da língua portuguesa nesse mesmo campo. (LAGAZZI-RODRIGUES, 2002, p. 21, grifos da autora)

Para Geraldi (2004a), em entrevista a mim concedida ${ }^{16}$, particularmente se referindo à década de 1970, o ensino da disciplina Português estava centrado no conhecimento da gramática.

O ensino estava lastreado, fundamentalmente, no ensino de normas de uso da língua misturadas a descrições, com base na teoria gramatical tradicional, sobre alguns fenômenos do sistema lingüístico que eram apresentados como se fossem o todo, produzindo dois efeitos entre si complementares: primeiro o da existência de uma e somente uma forma adequada e correta de se usar a língua e, em segundo lugar, de uma completude da teoria gramatical, como se hipóteses de análises possíveis fossem a verdade sobre a língua.

$[\ldots]$

O ensino seguia o livro didático típico da época, um livro composto por um conjunto de unidades, sem qualquer unidade como um todo, pois cada unidade é independente da que lhe antecede e da que lhe segue. E você esperaria, digamos assim, que o aluno sistematizasse os conhecimentos na forma de uma gramática como um todo, depois do passeio por algumas descrições e pelas informações a propósito do bom uso da língua, incluídos neste bom uso fenômenos de diferentes ordens [...]. (p. 4)

Segundo Geraldi (2004a), havia um "repensar o ensino de língua portuguesa" que se instaurava no momento. E nesse "repensar" estavam contempladas as concepções linguísticas de base interacionista.

\footnotetext{
${ }^{16}$ Essa entrevista, que se encontra em anexo na minha dissertação de mestrado (PAULA, 2004a), foi realizada com Geraldi em novembro de 2002 e revisada pelo autor em junho de 2004.
} 
[...] repensar o ensino de língua portuguesa era repensar este ensino para lastreá-lo num conjunto de práticas de linguagem em que uma aula puxasse outra aula, que puxa outra aula, que puxaria outra aula, evitando recortes estanques e mostrando que a aprendizagem da linguagem se dá por práticas de linguagem e não por descrições e normatizações sobre a língua. (GERALDI, 2004a, p. 4)

$\mathrm{Na}$ década de 1980, preocupado, sobretudo, com o ensino de língua portuguesa e apoiando-se nas concepções linguísticas em voga naquele momento, destaca-se o pensamento de Geraldi sobre esse ensino. 
CAPÍTULO 2

APRESENTAÇÃO DE J. W. GERALDI= 


\subsection{Aspectos biográficos de J. W. Geraldi ${ }^{17}$}

João Wanderley Geraldi ${ }^{18}$, gaúcho nascido no dia 26 de dezembro de 1946, em São Luiz Gonzaga-RS, ficou conhecido tanto em âmbito nacional quanto internacional, da década de 1980 até os dias atuais, pela sua atuação no ensino de língua portuguesa em nosso país, especialmente pelos professores de língua portuguesa.

Unindo ideias advindas de outras áreas, como da Ciência, da Arte, da Educação e da Filosofia, a seu pensamento sobre linguagem, o linguista Geraldi participou ativamente da discussão dos problemas do ensino de língua portuguesa no Brasil, com formulação de uma proposta que qualifico, sobretudo, como apaixonada. Assim como a "serpente seduz e abocanha o batráquio", no texto "O cururu", do poeta alagoano Jorge de Lima (1994), também Geraldi é exímio autor, capaz de seduzir o leitor numa linguagem mais que tudo envolvente.

Seus textos revelam um "olhar para o outro" e o desejo de caminhar junto, como se refere o poeta Carlos Drummond de Andrade (2001), no poema "Mãos dadas".

Filho de imigrantes italianos agricultores pouco alfabetizados, Laudelino e Maria Geraldi, Geraldi teve por formação inicial, na cidade de Santo Ângelo-RS: o primário, cursado no Grupo Escolar Industrial; três anos do ginásio, cursados no Seminário Apostólico Sagrada Família, um ano, no Colégio Santo Ângelo; e o Técnico em Contabilidade, na Escola Técnica de Comércio "Sepé Tiaraju”.

Profissionalmente, de 1962 a 1965, Geraldi foi office-boy e, de 1966 a 1972, bancário. Concomitantemente à profissão de bancário, no ano de 1966, foi convidado a assumir a função de professor. Inicialmente ministrou aulas nas disciplinas Geografia Geral e Geografia do Brasil, e, no ano seguinte, 1967, em Língua Portuguesa, numa trajetória iniciada enquanto trabalhava no Banco do Brasil. Isso ocorreu a partir de um convite para ministrar aulas de Geografia no Ginásio Comercial "São Luiz Gonzaga", mantido pela atual Campanha Nacional de Educandários da Comunidade, em sua cidade natal.

\footnotetext{
${ }^{17}$ Com atualizações, destaco, neste capítulo, aspectos biográficos de J. W. Geraldi apresentados em minha dissertação de mestrado (PAULA, 2004a).

${ }^{18}$ As informações aqui abordadas foram extraídas de: GERALDI (1995, 1999a, 2002, 2004a, 2006a); dos documentos: Processo $n^{o}$. 2965/72 - Reconhecimento dos cursos de bacharelado em Ciências Sociais, de Economia e de Lingüística ministrados pelo IFCH, volumes I e II; Processo n. 7968/76 - Constituição do Instituto de Estudos da Linguagem, e do documento IEL, notas sobre a UNICAMP e o IEL, 1982, todos localizados no Arquivo Central do Sistema de Arquivos (SIARQ), na UNICAMP; e em Cadernos de estudos lingüísticos, n. 1, publicado em 1978, sob a responsabilidade do Departamento de Linguística do IEL/UNICAMP.
} 
Em nível de Graduação, Geraldi concluiu ${ }^{19}$ os cursos de: bacharelado em Ciências Jurídicas e Sociais, cursado na Faculdade de Direito de Santo Ângelo, em Santo Ângelo-RS; e Licenciatura em Letras, primeiramente Licenciatura Curta $^{20}$, na Faculdade de Filosofia, Ciências e Letras de Santo Ângelo, mantida pela Fundação Missioneira de Ensino Superior (FUNDAMES) ${ }^{21}$, em Santo Ângelo-SP, no ano de 1970, e depois, a Licenciatura Plena em Letras, que foi cursada em Ijuí/RS, quando era professor do Departamento de Letras, na Faculdade de Filosofia, Ciências e Letras de Ijuí-RS, mantida pela Fundação de Integração, Desenvolvimento e Educação do Noroeste do Estado do Rio Grande do Sul (FIDENE), em Ijuí-RS.

Em 1972, inicia sua dedicação exclusiva à carreira de professor.

O passo seguinte, no ano de 1973, foi a Especialização em Linguística, ministrada por professores do Instituto de Estudos da Linguagem (IEL) da UNICAMP, no estado do Rio Grande do Sul.

Após esse curso, os seus horizontes se alargaram e ele deu início à sua trajetória acadêmica no estado de São Paulo: em 1976, iniciou o curso de mestrado em Linguística no IEL/UNICAMP; em 1980, o doutorado, fixando, a partir desse ano, residência em Campinas$\mathrm{SP}$, até o momento, entre suas idas e vindas atuais ao exterior, principalmente à Alemanha e a Portugal.

Nesses países, Geraldi realizou parcerias com professores de algumas universidades, muitas das quais resultaram em sua participação em eventos e na publicação de textos, os quais apresento no Capítulo 3. Na Universidade de Aveiro, Geraldi ministrou um curso com a duração de seis meses no ano letivo de 2002/2003, conforme calendário letivo de Portugal.

A trajetória do interior do estado do Rio Grande do Sul ao interior do estado de São Paulo rendeu a Geraldi um aprimoramento em sua formação, o que the proporcionou inúmeras atuações e consequente comprometimento com o ensino de língua portuguesa.

Geraldi foi chefe do Departamento de Ensino da FUNDAMES, de 1972 a 1974; diretor da Coordenadoria de Pesquisa, Planejamento e Documentação do Museu

\footnotetext{
${ }^{19}$ Geraldi iniciou o curso de Economia na Faculdade de Ciências Econômicas e Administrativas, em Cruz Alta/RS, sem, no entanto, concluí-lo.

${ }^{20}$ Em decorrência da Lei $n^{\circ} .7044$, de 18 de Outubro de 1982, "Licenciatura Curta" era a denominação do grau universitário que dava o direito de exercer o magistério no Ensino de $1^{\circ}$. Grau de $5^{\mathrm{a}}$. a $8^{\mathrm{a}}$. série; e "Licenciatura Plena", o grau universitário que dava o direito de exercer o magistério no Ensino de $2^{\circ}$. Grau, além do Ensino de $1^{\circ}$. Grau.

${ }^{21}$ FUNDAMES é a entidade mantenedora das faculdades existentes em Santo Ângelo/RS.
} 
Antropológico "Diretor Pestana", em Ijuí/RS, enquanto era professor universitário da FIDENE, no período entre setembro de 1978 e março de 1980.

Ele foi presidente da Associação de Leitura do Brasil (ALB), entidade responsável pela publicação do periódico Leitura: teoria \& prática e pela organização dos COLES, com sede em Campinas-SP, no período de 1987 a 1989. Como presidente da ALB, foi o responsável geral pela organização do $7^{\circ}$. COLE, realizado em 1989, na UNICAMP, em Campinas.

Geraldi assessorou secretarias estaduais e municipais de educação do país e participou da elaboração de propostas curriculares e diretrizes para o ensino de língua portuguesa. Junto à Comissão Nacional para Elaboração de Diretrizes para o Ensino e Aprendizagem da Língua Portuguesa, no Ministério da Educação, ele substituiu Magda Soares ${ }^{22}$ e, posteriormente, Aurélio Buarque de Holanda Ferreira ${ }^{23}$.

Além dessas atividades, ministrou inúmeras palestras, cursos e seminários, e participou também de inúmeras conferências e congressos.

Foi professor no Departamento de Letras da FIDENE, como já informado, e no IEL. Nesse último instituto, foi orientador de dissertações de mestrado e de teses de doutorado; do IEL, foi também diretor.

De 1980, ano de seu ingresso na UNICAMP, até 1995, quando escreveu o memorial para concurso de livre docência na graduação em Linguística, Geraldi ministrou 28 disciplinas diferentes no IEL. As disciplinas contemplaram os estudos semânticos, a análise do discurso, a variação linguística e as descrições gramaticais do português.

Durante quase um ano, de 27/04/98 a 05/04/99, Geraldi atuou como pró-reitor de extensão e assuntos comunitários da UNICAMP.

Ele foi representante dos docentes do IEL junto ao Conselho de Representantes da Associação de Docentes da UNICAMP (ADUNICAMP) e também segundo vice-presidente dessa associação, no período de novembro de 1993 a outubro de 1994.

Geraldi foi o primeiro coordenador do Setor de Publicações do IEL, tendo atuado nessa função por 11 anos, na publicação dos periódicos Cadernos de estudos lingüísticos e Trabalhos em lingüistica aplicada. A edição número 24 de Cadernos de estudos lingüísticos,

\footnotetext{
${ }^{22}$ Magda Becker Soares é professora emérita da Universidade Federal de Minas Gerais (UFMG). Segundo informações que constam em seu currículo, no Sistema de Currículos Lattes, consultado em 09 de dezembro de 2009, ela possui graduação em Letras Neolatinas e doutorado em Didática pela UFMG. Atualmente é membro da Associação Nacional de Pós-Graduação e Pesquisa em Educação e do Comitê Assessor do CNPq. Atua na área de Educação, com ênfase em ensino-aprendizagem.

${ }^{23}$ Aurélio Buarque de Holanda Ferreira (1910-1989) nasceu em Passo de Camaragibe/AL e morreu no Rio de Janeiro/RJ. Atuou como crítico literário, ensaísta, tradutor, filólogo, lexicógrafo e professor.
} 
em comemoração aos 15 anos de publicação da revista, rendeu homenagens ao seu primeiro coordenador.

O autor desenvolveu, na UNICAMP, em 1986, juntamente com outros pesquisadores, projeto a respeito do estado da arte sobre o livro didático, o qual foi financiado pelo INEP. Dessa atividade resultou a seguinte publicação Que sabemos sobre livro didático: catálogo analítico, cuja referência completa consta no Apêndice A.

Sua atuação aconteceu também junto a conselhos editoriais de inúmeros periódicos, em alguns dos quais ainda atua: Cadernos de estudos lingüisticos, editado pelo Departamento de Linguística do IEL/UNICAMP (Campinas-SP); Leitura: teoria \& prática, editada pela ALB e pela Editora Mercado Aberto (Porto Alegre-RS); Revista da FAEEBA, editada pela Faculdade de Educação da Universidade do Estado da Bahia; e Educação e Realidade, editada pela Faculdade de Educação da Universidade Federal do Rio Grande do Sul (Porto Alegre-RS); Filologia e lingüística portuguesa, da Universidade de São Paulo (USP) (São Paulo/SP); Educação \& contemporaneidade, da Universidade do Estado da Bahia (UNEB) (Salvador-BA); Signo, da Universidade de Santa Cruz do Sul (UNISC) (Santa Cruz do SulRS); Letras, da Pontifícia Universidade Católica de Campinas (PUC-Campinas) (Campinas/SP); Espaço pedagógico, da Universidade de Passo Fundo (UPF) (Passo FundoRS); Cadernos Camilliani, do Centro Universitário São Camilo (CUSC) (Cachoeiro de Itapemirim/ES); e um periódico português, Palavras, da Associação de Professores de Português (APP) (Portugal).

Em novembro de 2002, Geraldi foi promovido a professor titular do IEL/UNICAMP, e, quase um ano depois, em outubro de 2003, aposentou-se.

Por ocasião das comemorações dos 20 anos da FUNDAMES, em 26-11-83, Geraldi recebeu o título de "Colaborador Benemérito" dessa instituição, pelos serviços prestados quando da transformação dessa instituição em universidade. Por ocasião do $15^{\circ}$. COLE, realizado na UNICAMP, em julho de 2005, Geraldi recebeu a homenagem de amigos, professores de todo o país e professores estrangeiros, assim como de seus colegas, professores da UNICAMP e ex-orientandos pelos 20 anos de publicação da coletânea $O$ texto na sala de aula, momento em que foi ressaltado o sucesso de suas várias edições, de 1984 até aquela data. Na realização do $16^{\circ}$. COLE, na UNICAMP/Campinas, em julho de 2007, Geraldi foi agraciado com o título de "Presidente de Honra" da ALB.

Atualmente, atua no IEL/UNICAMP, como professor colaborador voluntário; é membro do corpo editorial de vários periódicos; como professor visitante, participa de programas de pós-graduação em Educação na Universidade do Porto e na Universidade de 
Aveiro, em Portugal; como professor e pesquisador associado do Programa Internacional de Doutorado em Educação (INEDD), na Universidade de Siegen, na Alemanha, colabora atualmente na orientação de doutorandos brasileiros.

Quanto à produção científica, atualmente, Geraldi se dedica em especial ao estudo e à produção de textos sobre Mikhail Bakhtinn ${ }^{24}$, Paulo Freire ${ }^{25}$ e Lev Vigotski ${ }^{26}$, unindo ideias sobre questões políticas, filosóficas, éticas, educacionais e científicas.

\subsection{Formação acadêmica}

\subsubsection{Em instituições do estado do Rio Grande do Sul}

Sobre a formação acadêmica de Geraldi, realizei um instrumento de pesquisa intitulado Formação acadêmica de J. W. Geraldi: um instrumento de pesquisa (2009c), localizado no Apêndice $\mathrm{C}$ desta tese, como anteriormente informado.

Nesse instrumento de pesquisa, encontram-se as informações referentes tanto à formação acadêmica inicial de Geraldi, no estado do Rio Grande do Sul, quanto à formação acadêmica no estado de São Paulo, no IEL/UNICAMP.

Localizei documentos nos quais constam informações sobre 11 cursos realizados por Geraldi no período compreendido entre 1972 e 1978, no estado do Rio Grande do Sul, nas cidades de Santa Maria, Santo Ângelo, Ijuí, Santa Rosa e Porto Alegre.

Além disso, localizei também documentos sobre a constituição do primeiro Departamento de Linguística do Brasil: IEL/UNICAMP.

Considerando especialmente a graduação em Letras, Geraldi foi aluno, dentre outros professores, de Ingo Voese ${ }^{27}$, ainda em seu estado de origem.

Segundo Geraldi (2004b), o professor Voese ministrava as disciplinas Linguística e Língua Portuguesa, na Faculdade de Filosofia, Ciências e Letras, mantida pela FUNDAMES.

\footnotetext{
${ }^{24}$ O pensador Mikhail Mikhailovich Bakhtin (1895-1975), conhecido por seus estudos sobre a filosofia da linguagem, nasceu em Orel/Rússia, ao sul de Moscou. Estudou Filosofia e Letras na Universidade de São Petersburgo. No Brasil, ficou conhecido a partir da década de 1980, inicialmente na área da Literatura.

${ }^{25}$ Paulo Freire (1921-1997) nasceu em Recife/PE e faleceu em São Paulo/SP. Foi um grande educador brasileiro, que esteve sempre comprometido com a educação popular, tendo ficado conhecido internacionalmente. Por esse motivo, no momento da Ditadura Militar brasileira, foi exilado. Após o exílio, de volta ao Brasil, Paulo Freire destacou-se por sua atuação junto à Prefeitura de São Paulo, de 1989 a 1991, quando foi Secretário de Educação. Na UNICAMP, foi professor titular da FE/UNICAMP, durante 11 anos, de 1980 a 1991.

${ }^{26}$ Lev Vigotski (1896-1934) nasceu em Orsha/Bielorússia e morreu na Rússia, ainda jovem. Ficou conhecido por seu pensamento sobre o desenvolvimento do sujeito a partir do meio em que ele vive.

${ }^{27}$ O professor Ingo Voese (1940-2007) nasceu em Santa Cruz do Sul/RS. Formado em Letras, foi professor de Linguística e Língua Portuguesa da FIDENE, atualmente Universidade Regional do Noroeste do Estado do Rio Grande do Sul (UNIJUí). Quando Geraldi foi diretor de ensino da FUNDAMES, em 1972, Ingo Voese foi seu colega de trabalho nessa instituição, no ano de 1973, ministrando aula de Estudos linguísticos.
} 
Com relação ao assunto das aulas, reproduzo, abaixo, as ideias linguísticas que as embasavam:

Eram tempos de hegemonia do pensamento estruturalista. Em Lingüística, tratava-se de utilizar os procedimentos de descoberta elaborados como princípios de análise. Fazia-se análise fonêmica e morfofonêmica. Apenas começavam a circular alguns textos da então chamada Gramática GerativoTransformacional, ingenuamente apresentada e saudada como se fora uma superação do estruturalismo! Mas nas aulas e nos interesses do nosso professor não havia apenas o estruturalismo: de memória, lembro até hoje a matriz morfológica do verbo português, por ele elaborada e praticamente coincidente com aquela de Mattoso em A estrutura da Língua Portuguesa, que depois chegaria a nossas mãos. Mas o que discutíamos em aulas, e principalmente fora delas, eram a Gramatologia de Derrida, a Ordem do Discurso de Foucault, a Reprodução de Bourdieu e Passeron, em traduções para uso didático, bem anteriores às publicações brasileiras destes textos. Folheávamos "apostilas", reproduzidas em mimeógrafo a tinta, a tecnologia então avançava para o interior do Rio Grande do Sul. Estávamos nos inícios dos anos 70 e como estávamos longe das cópias xerográficas! (GERALDI, 2004b, p. 9-10)

Sobre a aprendizagem a partir das aulas de Voese, Geraldi tece ainda os seguintes comentários:

[...] mais do que um conjunto de conhecimentos, tratado com seriedade sem sofisticação. Aprendi a curiosidade natural da atenção ao genérico sem perder de vista o singular; aprendia a amorosidade do gesto de ensinar sem deixar de aprender sempre; aprendi a não perder de vista um horizonte futuro, ainda que longínquo. (GERALDI, 2004b, p. 10-11)

E também sobre o momento em que Voese ministrava aulas na Faculdade de Filosofia, Ciências e Letras de Santo Ângelo, tece mais comentários sobre as ideias estruturalistas divulgadas:

[...] era nosso calcanhar de Aquiles: qual o sentido, afinal, da fórmula mattosiana do verbo em português? Por que não se podia interpretar? Lembro de minha incapacidade de compreender certas passagens de um texto de Derrida que o grupo da filosofia de Ijuí tinha traduzido e estava estudando: como que o centro que sustenta a estrutura está fora da estrutura? (GERALDI, 2008a, p. 18)

Naquele momento, em Linguística, concomitantemente às concepções estruturalistas, destacavam-se as concepções da Gramática Gerativa, da Sociolinguística, da Teoria da Enunciação e, com mais timidez, as da Análise do Discurso (AD), as quais abordarei no Capítulo 5 desta tese.

Com relação aos demais professores que participaram da formação acadêmica inicial de Geraldi, no período compreendido entre 1970, quando iniciou a Licenciatura Curta em 
Letras, até 1978, quando concluiu o mestrado no IEL/UNICAMP, foi-me possível localizar informações sobre parte dessa formação acadêmica, obtida especialmente em instituições de ensino do interior do Rio Grande do Sul, quando Geraldi participou de diversos cursos de formação de professores, as quais constam no Apêndice $\mathrm{C}$ desta tese, como informado anteriormente.

Quanto aos cursos, "Renovação da Gramática à luz da Lingüística", composto por uma carga horária de 75 horas-aula, foi cursado por Geraldi em 1972. Esse curso foi realizado na Faculdade de Filosofia, Ciências e Letras "Imaculada Conceição", agregada à Universidade Federal de Santa Maria-RS (UFSM), tendo sido ministrado pelos professores Dr. Silvio Elia ${ }^{28}$, Eurico Back $^{29}$ e Dr. Wilson Guarany ${ }^{30}$. Três conteúdos-base compunham esse curso: "Introdução à Lingüística", ministrado pelo professor Dr. Wilson Guarany; "Lingüística construtural", ministrado pelo professor Eurico Back; e "Gramática transformacional", pelo professor Dr. Silvio Elia. No conteúdo-base "Introdução à Lingüística", os conteúdos estudados foram: "Problemas de metanálise" e "Problemas de análise". No primeiro, foram abordados os seguintes conteúdos: "Lingüística e ciência"; "Filologia, Lingüística e Gramática"; "Metalinguagem"; "Estrutura e estruturalismo"; "Noção de modelo"; "Descrição lingüística, coerência e dedutibilidade" e "Imanência e pertinência". E, em "Problemas de análise", foram abordados os conteúdos: "As dicotomias saussurianas", "Fonética e Fonologia", "A Sintaxe Distribucional e a Sintaxe Transformacional" e "O significado: a análise sêmica". No conteúdo-base "Lingüística construtural”, foram estudados os conteúdos: "Paralinguagem e metalinguagem", "Variáveis e constantes. Estilística", "Estudo do significante", "Semântica", “Criatividade ('performance')" e "Lingüística aplicada"; e no conteúdo-base "Gramática transformacional”, foram abordados os conteúdos: "Antecedentes da gramática gerativo-transformacional", "Gramaticalidade", "Estruturas de base: sintagma nominal, sintagma verbal, sintagma proposicional, sintagma adjetival" e "Transformações".

O curso "Lingüística aplicada ao ensino de língua nacional", composto por uma cargahorária de 40 horas-aula, também foi cursado por Geraldi em 1972. Esse curso foi realizado na Faculdade de Filosofia, Ciências e Letras de Santo Ângelo e ministrado pelos seguintes

\footnotetext{
${ }^{28}$ O professor e linguista Dr. Silvio Elia (1913-1998) nasceu no Rio de Janeiro/RJ. Nessa cidade, estudou na Escola Municipal "Eusébio de Queirós" e no Colégio "Pedro II". Cursou bacharelado em Ciências Jurídicas, pela Faculdade Nacional de Direito da Universidade do Brasil. Doutorou-se pela Faculdade de Letras da Universidade Federal do Rio de Janeiro (UFRJ); foi titular de Linguística da Faculdade de Letras da UFRJ e professor catedrático de Latim do Colégio "Pedro II". Foi também fundador e presidente do Círculo Linguístico do Rio de Janeiro, membro da Academia Brasileira de Filologia e da Academia de Língua Portuguesa do Rio Grande do Sul.

${ }^{29} \mathrm{O}$ professor Eurico Back foi professor da Universidade Federal do Paraná (UFPR).

${ }^{30} \mathrm{O}$ professor Wilson Guarany atuou na Universidade Federal do Rio Grande do Sul (UFRGS).
} 
professores: Sebastião Josué Votre ${ }^{31}$, Anselmo Berwanger ${ }^{32}$, Angelo Dante Biz ${ }^{33}$ e Arieta Antas $^{34}$. Três conteúdos-base compunham o curso: "Lingüística Estrutural e Transformacional", ministrado pelo professor Sebastião Josué Votre; "Lingüística construtural", ministrado pelo professor Anselmo Berwanger; "Semântica", ministrado pelo professor Ângelo Dante Biz; e "Estruturas sintáticas", ministrado pela professora Arieta Antas. No conteúdo-base "Lingüística Estrutural e Transformacional", foram estudados os conteúdos: "Visão retrospectiva, perspectiva e prospectiva da Lingüística", "Lingüística estrutural - correntes estruturalistas", "Lingüística transformacional - o enfoque chomskyano", "Tentativas de aplicação ao português", "O programa sugerido pela SEC análise, crítica e abordagem dos principais tópicos"; no conteúdo-base "Lingüística construtural", foram estudados os conteúdos: "Tentativa de uma teoria globalizante", "Relações estruturais" e "Modelos de análise"; no conteúdo-base "Semântica", foram estudados os conteúdos: "O sentido do sentido" e "Tipos de sentido (sentido denotativo, sentido conotativo, sentido estrutural)"; e, em "Estruturas sintáticas": "Partes do discurso e palavras funcionais", "Processos de substituição", "Operações de expansão básica", “Transformações simples" e "Operações de oração subordinativa".

O curso "Filosofia e linguagem", composto por uma carga-horária de 30 horas-aula, foi cursado por Geraldi em 1973. Esse curso foi realizado na Faculdade de Filosofia, Ciências e Letras de Santo Ângelo, pelos professores do Departamento de Filosofia e Letras da FIDENE. O curso foi composto por três conteúdos-base: "O projeto metafísico do Ocidente", "A crise do pensamento contemporâneo" e "O problema da linguagem". No conteúdo-base "O projeto metafísico do Ocidente", foram estudados os seguintes conteúdos: "Mito e logos", "Platão (o pensamento grego)", "O pensamento teológico-metafísico da Idade Média", "A modernidade: o saber moderno e a subjetividade", "O iluminista: racionalista, empirista, idealista", "O idealismo alemão: Kant e Hegel”, "Marx e as descontinuidades históricas" e "O processo de destruição do projeto metafísico: Nietzche, Freud, Marx". Em "A crise do pensamento contemporâneo", os conteúdos estudados foram: "Heidegger", "Sartre" e "A estrutura, o signo e o jogo no discurso das ciências humanas". Em "O problema da linguagem", foram estudados os conteúdos: "A linguagem: a fala, a escuta e a resposta",

\footnotetext{
${ }^{31}$ O professor Sebastião Josué Votre iniciou a carreira acadêmica como professor e pesquisador na UNIJUí em 1968. Desde 1986, pesquisa as relações entre linguagem verbal e linguagem não-verbal. Atualmente é professor titular na USP.

${ }^{32}$ Não localizei informações sobre o professor Dr. Anselmo Berwanger.

${ }^{33} \mathrm{O}$ professor Angelo Dante Biz é padre da Arquidiocese de Florianópolis/SC.

${ }^{34}$ Não localizei informações sobre a professora Arieta Antas.
} 
"Prolegômenos para uma teoria da linguagem", "As ordens do discurso" e "Poemas de Fernando Pessoa".

No curso "Lingüística aplicada ao português", realizado na Faculdade de Filosofia, Ciências e Letras, da UFSM, também no ano de 1973, foram professores de Geraldi: José Olavo Neis ${ }^{35}$, Sebastião Josué Votre e Celso Pedro Luft ${ }^{36}$. O professor José Olavo Neis ministrou os seguintes conteúdos: "Possibilidades de aprendizagem de uma língua estrangeira", "Métodos mais difundidos de ensino", "Aprendizagem de idiomas", "Vantagens e desvantagens dos métodos estruturais" e "O recurso dos auxílios áudio-visuais"; o professor Sebastião Josué Votre ministrou os seguintes conteúdos: "Modalidades de abordagem gramatical de uma língua", "Gramática transformacional vs Gramática Estrutural”, "O profissional do ensino da língua", "Vantagens de um bom treinamento lingüístico", "Gramática transformacional e o ensino da composição", "Lingüística, usos e usuários", "Como não interferir na aprendizagem da língua" e "Organização estrutural da linguagem gramática"; e o professor Celso Pedro Luft ficou responsável pelos conteúdos: "Gramática Transformacional da Língua Portuguesa", "Conceito de gramática”, "Gramática gerativotransformacional", "Componentes da gramática e elaboração de gramáticas", "Derivação e diagramação da estrutura", "Conceito de transformação", "Transformações simples e generalizadas", "Nominalização" e "Relativização".

No curso "Introdução à Semântica e Prática de ensino da língua portuguesa", do qual Geraldi participou na Faculdade de Filosofia, Ciências e Letras de Ijuí, também em 1973, foi seu professor Dr. Eurico Back. Dois conteúdos-base, "Introdução à Semântica" e "Prática de ensino de língua portuguesa", compuseram o curso. No conteúdo-base "Introdução à Semântica", foram estudados os seguintes conteúdos: "Comunicação", "Análise do sinal”, "Relações semânticas da cláusula", "Conceito de trajeto semântico", "Alinhamento do trajeto semântico" e "Trajeto cultural do morfema"; e no conteúdo-base "Prática de ensino de língua portuguesa", foram estudados os conteúdos: "Comunicação", "Processos genéticos de aprendizagem", "Criatividade", "Planejamento do ensino" e "Execução do ensino".

No “1. Seminário de Estudos de Metodologia do Ensino Superior", de 45 horas-aula, do qual Geraldi participou na Faculdade de Filosofia, Ciências e Letras de Santo Ângelo, em 1974, foi sua professora Aretê Saldanha Vargas ${ }^{37}$. Nesse curso, cinco conteúdos-chave foram estudados: “A formação de recursos humanos para a educação e a universidade do Rio

\footnotetext{
${ }^{35}$ O professor José Olavo Neis foi professor da UNIJUÍ.

${ }^{36}$ Celso Pedro Luft (1921-1995) foi professor de Língua Portuguesa da UFGRS, dicionarista e autor de gramáticas e manuais de ortografia.

${ }^{37}$ Não localizei informações sobre a professora Aretê Saldanha Vargas.
} 
Grande do Sul", "Estrutura regimental da Faculdade", "Cursos e currículos", "Conteúdos programáticos" e "Planejamento de atividades".

Geraldi também participou do curso "Problemas de poética e lingüística portuguesa", ministrado pelos professores Dr. Wilson Guarany e Celso Pedro Luft, na Faculdade de Filosofia, Ciências e Letras Dom Bosco, de Santa Rosa-RS, em 1974, porém, não foi possível localizar os conteúdos que compuseram o curso.

Em "Problemas de Comunicação e Linguagem", curso realizado na Faculdade de Filosofia, Ciências e Letras de Santo Ângelo, também em 1974, há uma divisão desse curso em duas etapas. Na primeira, foram propostos para estudo os conteúdos "Definição do signo: Saussure e Peirce", "Problemas de análise do significado", “A Gramática Estratificacional e o significado", "Bernard Pottier e a análise do significado" e "A Semântica Estrutural de Julien Greimas"; e, na segunda etapa, os conteúdos: "Estruturalismo: aquisições e limites", "Gramática gerativo-transformacional: aquisições e limites" e "Categorias, relações e transformações do português", sem informações sobre a carga horária.

Em "Curso de aperfeiçoamento em Filosofia", realizado na Faculdade de Filosofia, Ciências e Letras de Ijuí, em 1975, pelos professores Silvino Santin ${ }^{38}$, José Fagundes ${ }^{39}$ e Euclides Redin ${ }^{40}$, tendo 195 horas-aula, foram estudados os conteúdos: "Antropologia Filosófica", "História da Filosofia", "Metodologia do Ensino Superior" e "Estudos dos problemas brasileiros".

O "Curso de Especialização em Lingüística", realizado na Faculdade de Filosofia, Ciências e Letras da UNIJUÍ, e concluído em 1976, foi ministrado pelos professores Dr.

\footnotetext{
${ }^{38}$ Segundo informações que constam em seu currículo, no Sistema de Currículos Lattes, consultado em 10 de dezembro de 2009, o professor Silvino Santin possui graduação pela UNIJUí, especialização pela UFRJ, mestrado pela Université de Paris X e doutorado pela Université de Paris IV. Atua no momento como professor titular da UFSM.

${ }^{39}$ Segundo informações que constam em seu currículo, no Sistema de Currículos Lattes, consultado em 10 de dezembro de 2009, o professor José Fagundes possui graduação em Filosofia e em Pedagogia pela UNIJUÍ, graduação em Bacharel em Teologia e Licenciatura em Teologia pela Universidade de Fribourg, mestrado em Filosofia da Educação pelo Instituto de Estudos Avançados em Educação da Fundação Getúlio Vargas e doutorado em Filosofia e História da Educação pela UNICAMP. Atualmente é professor adjunto da Faculdade Estadual de Filosofia Ciências e Letras de União da Vitória/PR (FAFIUV).

${ }^{40}$ Segundo informações que constam em seu currículo, no Sistema de Currículos Lattes, consultado em 10 de dezembro de 2009, o professor Euclides Redin possui graduação em Pedagogia pela Faculdade de Filosofia, Ciências e Letras "Nossa Senhora da Imaculada Conceição", mestrado em Educação pela PUC-RJ e doutorado em Psicologia Escolar e do Desenvolvimento Humano pela USP. Atualmente é professor titular na Escola Superior de Teologia (EST), em São Leopoldo/RS, junto ao Programa de Pós Graduação em Teologia. Atua na área de Educação, com ênfase em Psicologia Educacional, atuando principalmente nos temas: políticas educacionais, educação, educação infantil, escola e desenvolvimento infantil.
} 
Aryon Dall'Igna Rodrigues ${ }^{41}$ e Ms. Maria Laura Trindade Mayrink $^{42}$, tendo sido constituído por 24 créditos, distribuídos em quatro conteúdos: "Organização da Gramática e Fonologia”, "Introdução à Gramática Gerativa: Sintaxe", "Fonologia do Português" e "Monografia". Todos os conteúdos foram ministrados pelo professor Dr. Aryon Dall'Igna Rodrigues, que, apenas para o conteúdo "Fonologia do Português" teve a participação da professora Ms. Maria Laura Trindade Mayrink.

O "Encontro de professores de cursos de Letras do Rio Grande do Sul", ministrado na Associação de Escolas Superiores de Formação de Profissionais do Ensino (AESUFOPE) DAU/SEC/RS - PUC-RS, frequentado por Geraldi em 1978, foi constituído por 20 horasaula.

Em todos esses cursos de que Geraldi participou atuaram os professores: Angelo Dante Biz, Anselmo Berwanger, Aretê Saldanha Vargas, Arieta Antas, Aryon Dall'Igna Rodrigues, Celso Pedro Luft, Euclides Redin, Eurico Back, José Fagundes, José Olavo Neis, Maria Laura Trindade Mayrink, Sebastião Josué Votre, Silvino Santin, Silvio Elia e Wilson Guarany.

Com exceção do “1. Seminário de Estudos de Metodologia do Ensino Superior” e do "Curso de aperfeiçoamento em Filosofia", todos os demais cursos de que Geraldi participou naquele momento estavam vinculados às várias áreas da linguagem: gramática, filologia, fonética, fonologia, semântica, linguística aplicada, discurso, poética, comunicação e ensino de língua portuguesa. As diversas concepções das ciências linguísticas, a partir dos pensamentos de Ferdinand de Saussure ${ }^{43}$, Noam Chomsky ${ }^{44}$, Charles Sanders Peirce ${ }^{45}$, Bernard Pottier ${ }^{46}$ e Algirdas Julius Greimas ${ }^{47}$, dentre outros, foram-lhe apresentadas pelos professores dos cursos de que Geraldi participou. As teorias apresentadas versavam sobre

\footnotetext{
${ }^{41}$ Aryon Dall'Igna Rodrigues (1925- ) iniciou sua atuação no ensino superior em 1960, na UFPR. Atuou na UNICAMP, de 1973 a 1988. Dedicou-se a atividades na área de Linguística, especialmente em Linguística Descritiva, em Linguística Histórica e em Línguas Indígenas, segundo informações de seu currículo, que consta no Sistema de Currículos Lattes, consultado em 20 de novembro de 2009.

${ }^{42}$ Maria Laura Trindade Mayrink atuou no IEL/UNICAMP, na área de Aquisição de Leitura e Escrita.

${ }^{43}$ Ferdinand de Saussure (1857-1913), linguista e filósofo suíço, nasceu em Genebra/Suíça e faleceu em Morges/ Suíça. Sua atuação proporcionou o desenvolvimento da Linguística enquanto ciência e a divulgação do Estruturalismo linguístico.

${ }^{44}$ Noam Chomsky (1928- ), linguista, nasceu na Filadélfia/EUA, e atua, desde 1955, no Instituto Tecnológico de Massachusetts. Destaca-se pelos estudos da Gramática Gerativa.

${ }^{45}$ Charles Sanders Peirce (1839-1914), filósofo, cientista e matemático, nasceu em Cambridge e faleceu em Milford. Ele se licenciou em ciências e se doutorou em Química, em Harvard. Ele ensinou Filosofia em Harvard e na Universidade de John Hopkins. Fundou o Pragmatismo e a Semiótica.

${ }^{46}$ Bernard Pottier (1924- ) , linguista francês, estudou o americanismo na França.

${ }^{47}$ Algirdas Julius Greimas (1917-1992), linguista francês, nasceu na Lituânia e faleceu na França. Destacou-se por seus estudos na área de Semântica Estrutural.
} 
concepções da Linguística e Gramática, principalmente a partir das perspectivas estruturalista e gerativa.

Geraldi tomava conhecimento dessas ideias linguísticas ao mesmo tempo em que também estudava as ideias filosóficas de: Platão ${ }^{48}, \mathrm{Kant}^{49}, \mathrm{Hegel}^{50}$, Marx $^{51}$, Nietzche ${ }^{52}$, Freud $^{53}$, Heidegger ${ }^{54}$ e Sartre ${ }^{55}$, como constam nos cursos de que participou, dois deles vinculados a questões filosóficas: "Filosofia e linguagem" e "Curso de aperfeiçoamento em Filosofia".

Ainda em seu estado de origem, Geraldi participou do Curso de Especialização em Linguística, na Faculdade de Filosofia, Ciências e Letras de Ijuí, mantida pela FIDENE, em convênio com a UNICAMP. O curso, composto por quatro módulos (três disciplinas e a monografia) e 24 créditos, como anteriormente mencionado, foi ministrado por professores da UNICAMP: Dr. Aryon Dall'Igna Rodrigues e Ms. Maria Laura Trindade Mayrink.

E, logo após o término do Curso de Especialização em Linguística, cuja conclusão data de 25 de março de 1976 (IEL, 1982), Geraldi ingressou no curso de mestrado em Linguística, na UNICAMP.

\subsubsection{No IEL/UNICAMP}

Após a conclusão do mestrado no IEL, Geraldi cursou nesse instituto também o doutorado, e, a partir de sua atuação, ficou conhecido, tanto no Brasil, quanto no exterior, especialmente pela divulgação de sua proposta para o ensino de língua portuguesa, concomitante à realização do doutorado.

Quanto à sua trajetória no IEL/UNICAMP, ela se funde à própria história do instituto, cujo Departamento de Linguística foi o primeiro a ser criado no país. Desde sua criação, que

\footnotetext{
${ }^{48}$ Platão (348 a. C.), filósofo e matemático do período clássico da Grécia antiga, caracteriza-se pela utilização do diálogo em suas aulas.

${ }^{49}$ Immanuel Kant (1724-1804), filósofo alemão, nasceu e morreu em Königsberg/Alemanha, onde lecionou na universidade de Königsberg. Ficou conhecido pelos estudos e divulgação do Idealismo Transcendental.

${ }^{50}$ Georg Wilhelm Friedrich Hegel (1770-1831), filósofo alemão, nasceu em Estugarda/Alemanha e faleceu em Berlim/Alemanha. Destacou-se no idealismo alemão do século XIX, que teve influência no materialismo histórico de Karl Marx.

${ }^{51}$ Karl Marx (1818-1883), intelectual alemão, nasceu em Tréveris/Alemanha e faleceu em Londres/Inglaterra. Foi o fundador da doutrina comunista moderna.

${ }^{52}$ Friedrich Nietzsche (1844-1900), filósofo alemão, nasceu em Röcken/Alemanha e faleceu em Weimar/ Alemanha. Ficou conhecido por sua crítica à cultura ocidental e suas religiões.

${ }^{53}$ Sigmundo Freud (1856-1939), médico neurologista judeu-austríaco, nasceu em Pribor/Áustria e faleceu em Londres/Inglaterra. É conhecido por sua teoria sobre o inconsciente.

${ }^{54}$ Martin Heidegger (1889-1976), filósofo alemão, nasceu em Mebkirgh/Alemanha e faleceu em Friburgo/Alemanha. Ficou conhecido por seu trabalho com o método fenomenológico.

${ }^{55}$ Jean Paul Sartre (1905-1980), filósofo e crítico francês, nasceu e faleceu em Paris/França. Destacou-se por seu conhecimento sobre o existencialismo.
} 
data de 1968, o Departamento de Linguística estava vinculado ao Instituto de Filosofia e Ciências Humanas (IFCH), da UNICAMP, e, somente em 1977, ganhou uma nova sede: o IEL (Processo n. 7968/76).

Quanto ao início dos cursos de mestrado e doutorado de Geraldi, as datas são coincidentes com as respectivas datas de reconhecimento e início dos cursos de pósgraduação do IEL: o mestrado em Linguística foi reconhecido em 30-12-1975 e iniciado por Geraldi em 1976; e o doutorado, reconhecido em 01-03-1979, ele o iniciou em 1980. (Processo n. 7968/76)

Os objetivos definidos para os cursos de Pós-Graduação em Linguística, na época, eram: a "descrição científica do português fundamental e de suas variações", o "estudo sistemático de idiomas estrangeiros", a "descrição de línguas indígenas", a "investigação sobre métodos e técnicas de ensino de idiomas estrangeiros e do idioma nacional" e a “investigação sobre métodos e técnicas fundamentais de tradução" (Processo n. 7968/76).

Naquele momento, também no IEL/UNICAMP, estavam em confronto, especialmente as concepções de base estruturalista e gerativa da linguagem.

Os estudos de Geraldi, quando iniciava seu curso de mestrado no IEL, em 1976, sob a orientação do professor Carlos $\operatorname{Vogt}^{56}$, estavam centrados em questões descritivas da linguagem, fundamentadas principalmente na Semântica Argumentativa, linha de pesquisa do IEL na época, assim como consta nos primeiros textos de Geraldi a serem publicados: na dissertação de mestrado Se a semântica fosse também pragmática... ou para uma análise semântica dos enunciados condicionais (GERALDI, 1978), que tematiza as questões descritivas da linguagem, e em Notas para uma tipologia dos enunciados condicionais (GERALDI, 1981), este último tendo sido apresentado para ingresso no doutorado.

Com relação às concepções da Semântica Argumentativa, para Guimarães (1995), ela se insere na Semântica da Enunciação, filiada aos estudos de Benveniste e à filosofia da linguagem, aos estudos de Austin. Guimarães (1995) atribui à Semântica Argumentativa as seguintes características:

\footnotetext{
${ }^{56}$ Carlos Alberto Vogt (1943- ) nasceu em Sales Oliveira-SP. Atuou na UNICAMP, na área de Linguística, de 1969 a 1995. Exerceu as seguintes atividades administrativas: coordenador geral da Universidade e vice-reitor da UNICAMP, de 1986 a 1990; reitor da UNICAMP, de 1990 a 1994; diretor executivo do Instituto do Fórum Permanente das Relações Universidade-Empresa (UNIEMP), de 1994 a 2001; coordenador do Laboratório de Estudos Avançados em Jornalismo (LABJOR), na UNICAMP, de janeiro de 1995 até a presente data; vicepresidente da Sociedade Brasileira para o Progresso da Ciência (SBPC), de 2001 a 2005; presidente do Centro Franco-Brasileiro de Documentação Técnica e Científica (CENDOTEC), de 2005 até a presente data; presidente da Fundação de Amparo à Pesquisa do Estado de São Paulo (FAPESP), de 2002 a 2007; e secretário de Estado do Ensino Superior, do governo do estado de São Paulo, desde agosto de 2007 até a presente data. Destacou-se no Brasil no estudo de uma perspectiva linguística estruturalista, segundo informações que constam em seu currículo, localizado no Sistema de Currículos Lattes, consultado em 20 de novembro de 2009.
} 
1. a questão da argumentação, considerada na retórica sob vários modos, aparece nesse caso com um tratamento que podemos chamar de lingüístico, no sentido de que a questão da argumentação é vista como uma relação de sentidos na linguagem; 2. esta abordagem como uma relação de linguagem se põe como uma questão enunciativa, ou seja, a argumentação não é uma relação da linguagem com o mundo, os objetos, ou derivada desta relação, é uma relação que orienta de um sentido para outro que se interpreta, então, como uma conclusão, numa enunciação particular; 3. a questão argumentativa pode ser importante para pensar a textualidade, de um lado, e a relação, que consideraremos posteriormente, entre interdiscurso/língua/enunciação, por outro. (p. 49)

O mestrado em Linguística, quando Geraldi o cursou, visava à formação de pesquisadores, sendo composta a grade curricular pelas seguintes disciplinas: Fonologia (Fonética e Fonologia), Sintaxe (Sintaxe Transformacional), Modelos de Análise Linguística, Semântica (Lógica e Linguagem I), Linguística Histórica (Variação e Mudança Linguística), de conhecimento geral; e Fonologia, Gramática, Semântica, Linguística Histórica e Comparativa, Análise do Discurso, Sociolinguística, Psicolinguística e Linguística Antropológica, de conhecimento específico (Cadernos de estudos lingüísticos, 1978). Havia também uma área de escolha do aluno, na qual ele podia optar por uma área da Linguística ou por uma área externa ao departamento (Cadernos de estudos lingüísticos, 1978). 
Inicialmente, atuavam como professores do Departamento de Linguística do IFCH: Haquira Osakabe ${ }^{57}$, Carlos Vogt, Rodolfo Ilari ${ }^{58}$ e Carlos Franchi ${ }^{59}$; e, logo depois, também: Aryon Dall'Igna Rodrigues, Ataliba Teixeira de Castilho ${ }^{60}$ e Marcelo Dascal ${ }^{61}$.

Segundo Ilari (2001), por Franchi deter uma "visão ampla de política universitária", convidou os professores Aryon Dall'Igna Rodrigues, Ataliba Teixeira de Castilho, Cláudia Thereza Guimarães de Lemos ${ }^{62}$, Marcelo Dascal, Mário Alberto Perini ${ }^{63}$ e Roberto Schwartz ${ }^{64}$ para atuarem no Departamento de Lingüística, que, “[...] junto com o grupo inicial, e um punhado de valores novos recrutados sobretudo no curso de Mestrado em Lingüística, formaram o corpo docente do Instituto de Estudos da Linguagem, criado em 1977” (ILARI, 2001, p. 2). O primeiro coordenador desse instituto foi o professor Antonio Cândido de Melo e Souza (ILARI, 2001).

\footnotetext{
${ }^{57}$ Haquira Osakabe (1939-2008) nasceu em Ribeirão Preto-SP. Iniciou sua atuação no ensino superior em 1969, no IFCH/UNICAMP, e após a inauguração do IEL, dedicou-se a atividades vinculadas a esse instituto, na área de Linguística e, principalmente, na área de Literatura Portuguesa.

${ }^{58}$ Rodolfo Ilari (1943- $)$ nasceu em Biella/Itália, tendo se naturalizado brasileiro em 1965. Iniciou sua atuação no ensino superior em 1969, no IFCH/UNICAMP, e após a inauguração do IEL, dedicou-se a atividades vinculadas a esse instituto, na área de Linguística, especificamente em Semântica, Pragmática, Linguística Românica e Ensino de língua portuguesa.

Rodolfo Ilari atua como professor colaborador voluntário na UNICAMP, na área de Linguística, com ênfase em Teoria e Análise Linguística.

${ }^{59}$ Carlos Franchi (1932-2001) nasceu em Jundiaí-SP; foi professor no magistério secundário e normal, conforme nomenclatura da época, ministrando concomitantemente aulas de língua portuguesa e latim. Ele exerceu, no ano de 1954, a função de professor no magistério secundário e normal, conforme nomenclatura da época, concomitantemente ao ensino das línguas português e latim, foi professor de português do Colégio de Aplicação da Faculdade de Filosofia, Ciências e Letras da USP, de 1957 a 1961; e "instrutor na cadeira de professor" de Didática Metodológica do Ensino do Vernáculo, na Faculdade de Filosofia, Ciências e Letras da USP, de 1959 a 1961. Ministrou aulas também de Literatura, na Universidade Anchieta dos Padres Jesuítas, em São Paulo, por dois anos, de 1969 a 1970. Em 1972, ministrou aulas de Linguística II, no Curso Básico de Ciências Humanas, no IFCH/UNICAMP. Além da docência, assumiu, dentre outras, as seguintes funções na área de Linguística: chefe do Departamento de Linguística, ainda no IFCH, em 1971; diretor associado do IEL; por eleição, foi diretor do IEL de 1979 a 1981; participou de um órgão da Secretaria Estadual da Educação do governo Montoro; foi presidente da Associação Brasileira de Linguística; e participou do Conselho Científico do CNPq. Em Jundiaí, exerceu a função de vereador. Destacou-se, no Brasil, por seu pensamento sobre a Gramática Gerativa, a qual, dentre outras questões, possibilitou-lhe a reflexão sobre a linguagem como atividade constitutiva.

${ }^{60}$ Ataliba Teixeira de Castilho, importante linguista brasileiro, atuou como professor titular da Faculdade de Filosofia de Ciências e Letras de Marília-Unesp, de 1961 a 1975; do IEL/UNICAMP, de 1975 a 1991, e da USP, de 1996 a 2005.

${ }^{61}$ Segundo informações que constam do Sistema de Currículos Lattes, consultado em 24 de novembro de 2009, Marcelo Dascal nasceu no Brasil e possui dupla cidadania: brasileira e israelense. Desde 1965 está em Israel, onde atua na Universidade de Tel-Aviv.

${ }^{62}$ Cláudia Lemos é formada em Letras Clássicas pela USP. Segundo informações que constam do Sistema de Currículos Lattes, consultado em 24 de novembro de 2009, é professora voluntária da UNICAMP. Sua experiência se destaca na área de Linguística, com ênfase na Aquisição de Linguagem, incluindo a Psicanálise.

${ }^{63}$ Segundo informações que constam do Sistema de Currículos Lattes, consultado em 24 de novembro de 2009, Mário Perini é formado em Letras, pela UFMG e atualmente é professor voluntário dessa universidade. Atuou também na PUC-Minas, na UNICAMP e nas universidades de Illinois e Mississípi. Sua atuação se destaca na área de análise linguística.

${ }^{64}$ Roberto Schwartz (1938- ), crítico literário e professor de Teoria Literária, nasceu em Viena/Áustria. Foi professor de Teoria Literária e Literatura Comparada na USP, e professor de Teoria Literária na UNICAMP.
} 
Compunham o corpo docente do Departamento de Linguística do IEL/UNICAMP,em 1978, quando Geraldi concluiu o curso de mestrado, os seguintes professores: Ângela Del Carmen Bustos Romero de Kleiman ${ }^{65}$, Antônio Carlos Quícoli' ${ }^{66}$, Aryon Dall'Igna Rodrigues, Ataliba Teixeira de Castilho, Brian Franklin Head ${ }^{67}$, Carlos Franchi, Carlos Alberto Vogt, Clarice Sabóia Madureira ${ }^{68}$, Cláudia Theresa Guimarães de Lemos, Ester Mirian Scarpa Gebara $^{69}$, Frank Roberts Brandon ${ }^{70}$, Haquira Osakabe, Jonas de Araújo Romualdo ${ }^{71}$, Luis Carlos Cagliari ${ }^{72}$, Marcelo Dascal, Marco Antônio de Oliveira $^{73}$, Maria Bernadete Abaurre Gnerre $^{74}$, Maria Cecília Perroni Simões ${ }^{75}$, Maria Fausta Pereira de Castro Campos ${ }^{76}$, Lucy Seki $^{77}$, Mário Alberto Perini, Maurizzio Gnerre ${ }^{78}$, Michel Lahud ${ }^{79}$, Rosa Attié Figueira ${ }^{80}$,

${ }^{65}$ Segundo informações que constam no Sistema de Currículos Lattes, consultado em 24 de novembro de 2009, Ângela Kleiman possui graduação em Letras pela Universidade do Chile, mestrado e doutorado em Linguística, pela Universidade de Illinois e pós-doutorado pela Universidade de Illinois e pela Universidade de Georgia. Atualmente, Kleiman é professora titular colaboradora voluntária na UNICAMP, atuando na área de Linguística, mais especificamente em Linguística Aplicada.

${ }^{66} \mathrm{O}$ professor Antônio Carlos Quícoli orientou na Pós-Graduação do IEL/UNICAMP, na área de Gramática Gerativa.

${ }^{67} \mathrm{O}$ professor Brian Franklin Head orientou na Pós-Graduação do IEL/UNICAMP, na área de Fonética.

${ }^{68}$ Segundo informações que constam no Sistema de Currículos Lattes, consultado em 10 de dezembro de 2009, a professora Clarice Sabóia Madureira possui doutorado em Letras pela UFPR e atualmente é professora adjunta da UFPR, atuando na área de Letras.

${ }^{69} \mathrm{~A}$ professora Ester Mirian Scarpa Gebara foi uma das docentes que passaram do IFCH para os Departamentos de Linguística e de Teoria Literária do IEL. (Processo n $n^{\circ}$. 2965/72, volume I, 1972).

${ }^{70} \mathrm{O}$ professor Frank Roberts Brandon atuou no IEL/UNICAMP, na área de Línguas Indígenas.

${ }^{71}$ Segundo informações que constam no Sistema de Currículos Lattes, consultado em 24 de novembro de 2009, Jonas de Araújo Romualdo possui graduação em Letras Vernáculas pela Universidade Federal da Bahia (UFBA), mestrado e doutorado em Linguística pela UNICAMP. Atualmente é professor na UNICAMP, atuando na área de Linguística, com ênfase em Retórica.

${ }_{72} \mathrm{O}$ professor Luis Carlos Cagliari (1945- ), linguista que atua na área da Fonética, é professor-adjunto no Departamento de Linguística da Faculdade de Ciências e Letras da Unesp de Araraquara, livre-docente e professor titular pela UNICAMP, segundo informações que constam no Sistema de Currículos Lattes, consultado em 24 de novembro de 2009.

${ }^{73} \mathrm{O}$ professor Marco Antonio de Oliveira cursou o doutorado em Linguística na Universidade da Pensilvânia. Foi professor da UNICAMP, de 1974 e 1980; foi professor da UFMG, de 1981 até 2003, e atualmente é professor adjunto da Pontifícia Universidade Católica de Minas Gerais (PUC-MG).

${ }^{74}$ A professora Maria Bernadete Abaurre possui graduação em Letras pela Universidade Federal do Espírito Santo (UFES), mestrado em Linguística pela UNICAMP e doutorado em Linguística, pela Universidade de Nova Iorque. Atualmente é professora titular de Fonética e Fonologia da UNICAMP.

${ }^{75}$ A professora Maria Cecília Perroni Simões atuou na Pós-Graduação do IEL/UNICAMP, na área de aquisição da linguagem.

${ }^{76}$ A professora Maria Fausta Pereira de Castro Campos possui graduação em Serviço Social pela PUC-Rio, graduação e mestrado em Psicologia, pela Universidade Paul Valéry Montepellier e doutorado em Linguística pela UNICAMP. Atualmente é professora titular do IEL/UNICAMP.

${ }^{77}$ A professora Lucy Seki é PhD em Línguas Indígenas Americanas e mestre em Filologia, com especialidade em Língua e Literatura Russa, pela Universidade Patrice Lumumba, de Moscou, e Bacharel em História pela UFMG. Atualmente é professora titular do IEL/UNICAMP.

${ }^{78} \mathrm{O}$ linguista italiano Maurizzio Gnerre trabalhou no Brasil e foi colega de Geraldi na UNICAMP, onde atuou na área da Sociolinguística.

${ }^{79} \mathrm{O}$ professor Michel Lahud atuou no curso de Letras do IEL/UNICAMP, na área de tradução, tendo sido responsável, juntamente com Yara Frateshi Vieira, pela tradução do livro Marxismo e filosofia da linguagem, de Mikhail Bakhtin.

${ }^{80}$ A professora Rosa Attié Figueira atua no Departamento de Linguística do IEL/UNICAMP, desde 1973, na área de Aquisição da Linguagem. Cursou mestrado e doutorado no IEL/UNICAMP e pós-doutorado em Paris, na Universidade de Sorbonne Nouvelle. 
Rodolfo Ilari, Tânia Maria Alkmin ${ }^{81}$, Vandersi Pereira Sant'ana ${ }^{82}$, Vera Lúcia Maia de Oliveira $^{83}$ e Waldyr Carvalho Luz ${ }^{84}$ (Cadernos de estudos lingüisticos, 1978).

Se Geraldi não foi aluno de todos esses professores, foi, com certeza, de pelo menos boa parte deles, ou com eles conviveu nos corredores do IEL, no auge da euforia de consolidação deste, o que comprova a importância do pensamento desses professores, senão de todos, de boa parte deles, em sua formação.

Com alguns deles, Geraldi estabeleceu parcerias ao longo de sua atuação, dentre as quais muitas resultaram na elaboração de textos, como destaco no Capítulo 3 desta tese. Muitos desses professores também constituíram o seu pensamento, o que menciono no Capítulo 5 desta tese.

Nessa época da atuação de Geraldi no ensino de língua portuguesa, final da Ditadura Militar no Brasil, havia uma propensão às reflexões sobre as preocupações que envolviam questões educacionais referentes, especialmente, a "para quê ensinar?", o que proporcionava uma maior reflexão sobre as práticas educacionais. Também movido por essas questões sobre o "para quê ensinar?", Geraldi passou a se preocupar com a linguagem e o seu ensino, tematizando-o em nosso país, também incluindo nesse âmbito, a alfabetização e privilegiando o texto como objeto de ensino.

Voltando ao estado do Rio Grande do Sul, após a conclusão do mestrado, em 1978, Geraldi elaborou o projeto "Unidades básicas para o ensino de português", o qual teve início em um curso que ministrava em Ijuí-RS, quando foi questionado, pelos professores-alunos, sobre o que "ensinaria" se fosse o professor que ministraria as aulas nos cursos de $1^{\circ}$. e $2^{\circ}$. graus, atuais Ensino Fundamental e Médio.

Esse projeto resultou na publicação de dois textos seus como "Subsídios metodológicos para o ensino de língua portuguesa: 5a a $8^{\mathrm{a}}$. Séries": "Ensino da língua ou ensino da metalinguagem?” e "Unidades básicas do ensino de língua portuguesa” (GERALDI,

\footnotetext{
${ }^{81}$ A professora Tânia Maria Alkmin possui graduação em Letras pela UFRJ, mestrado em Linguística pela UNICAMP, doutorado em Linguística pela Université de Paris V "René Descartes" e pós-doutorado pelo Centre National de la Recherche Scientifique (CNRS). Atualmente é professora associada da UNICAMP, segundo informações que constam em seu currículo Lattes, consultado em 20 de novembro de 2009.

${ }^{82}$ Vandersi Pereira Sant'ana possui Licenciatura em Letras pela Faculdade de Filosofia, Ciências e Letras de Assis, Licenciatura pela Faculté de Lettres et Sciences Humaines de Besançon, mestrado em Linguística pela UNICAMP e doutorado em andamento pela UNICAMP. Atualmente é professor do IEL/UNICAMP, na área de Linguística, em Dialeto Caipira, segundo informações que constam em seu currículo Lattes, consultado em 20 de novembro de 2009.

${ }^{83}$ A professora Vera Lúcia Maia de Oliveira foi uma das docentes que passaram do IFCH para os Departamentos de Linguística e de Teoria Literária do IEL. (Processo n ${ }^{\circ}$. 2965/72, volume I, 1972).

${ }^{84} \mathrm{O}$ professor Waldyr Carvalho Luz é pastor jubilado da Igreja Presbiteriana do Brasil. Atuou como professor de grego e hebraico no Seminário Presbiteriano do Sul e na área de Linguística no IEL/UNICAMP; e de grego e exegese do Novo Testamento no Instituto Bíblico Palavra da Vida.
} 
1981). A partir daí, iniciou a sua participação em projetos de formação de professores, e, em 1984, a partir de um projeto desenvolvido com a Editora da Associação Educacional do Oeste do Paraná (Assoeste), de Cascavel-PR, organizou a coletânea $O$ texto na sala de aula: leitura $\&$ produção (1984).

A tese de doutorado de Geraldi foi defendida em 1990, 12 anos após a conclusão do curso de mestrado, sob a orientação de Carlos Franchi, com o título Linguagem, interação e ensino (1990), que, com exceção de um capítulo, foi publicada posteriormente em livro, sob o título Portos de passagem (1991a), pela Martins Fontes (São Paulo), em 1991. Essa tese está embasada, sobretudo, nas concepções teóricas de Carlos Franchi, Mikhail Bakhtin e Michel Foucault ${ }^{85}$.

Dentre os professores que atuaram na formação de Geraldi, destaco seus orientadores: da dissertação de mestrado, Carlos Vogt, e da tese de doutorado, Carlos Franchi.

É visível o percurso de Geraldi: das concepções descritivas da linguagem para as discursivas, ao longo de sua formação e atuação, priorizando o ensino de língua portuguesa e provocando, com isso, o "deslocamento" dessas concepções linguísticas para o ensino de língua portuguesa.

\subsection{Os orientadores de Geraldi}

\subsubsection{Carlos Vogt e a perspectiva linguística estruturalista ${ }^{86}$}

Carlos $\operatorname{Vogt}^{87}$, importante linguista brasileiro, teve uma história de formação acadêmica construída na USP, na UNICAMP, na Universidade de Besançon (França), na EHESS (França), na University of South Florida (Estados Unidos da América) e na Mcgill University (Canadá).

\footnotetext{
${ }^{85}$ Michel Foucault (1926-1984) nasceu em Poitiers (França). Atuou como filósofo, sociólogo e professor de História no Collège de France, em Paris, de 1970 a 1984. Foi um dos precursores da Análise do Discurso (AD).

${ }^{86}$ As informações sobre a formação e atuação profissional de Carlos Vogt foram extraídas de seu artigo intitulado "Oswald Ducrot e a UNICAMP: uma visão pessoal", publicado em Cadernos de estudos lingüísticos, n. 35, em 1998; e de seu currículo, que consta no Sistema de Currículos Lattes, consultado em 04 de agosto de 2009.

${ }^{87}$ Carlos Vogt cursou Bacharelado em Letras, pela USP e, após a graduação, cursou: Especialização em "Licence en Lettres de Linguistique Certificat", pela Université de Besançon; Especialização em "Troisiéme Cycle Semantique Linguistica", pela École des Hautes Études en Sciences Sociales (EHESS), na França; Especialização em concurso para professor titular, pela UNICAMP; Mestrado em Letras (Teoria Literária e Literatura Comparada), pela USP, sob a orientação de Antonio Candido de Mello e Souza; Mestrado em Maitrise En Lettres D'enseignement Des Lettres pela Universidade de Besançon, sob a orientação de Jean Peytard; Doutorado em Linguística pela UNICAMP, sob a orientação de Oswald Ducrot; Pós-Doutorado pela University of South Florida, Estados Unidos da América, e também Pós-Doutorado na Mcgill University, em Montreal, Quebec, no Canadá, segundo dados que constam em seu currículo, no Sistema de Currículos Lattes, consultado em 20 de novembro de 2009.
} 
Na UNICAMP, ao longo de 26 anos, atuou como professor universitário na área de Linguística, de 1969 a 1995, desde quando está aposentado. A atuação profissional de Vogt se destaca por um viés linguístico interligado ao político. Na área da Educação, esteve sempre envolvido em cargos políticos e administrativos.

Sua formação na área linguística aconteceu no auge da perspectiva estruturalista da linguagem, quando, dentre outras atividades, teve a oportunidade de participar das palestras de Roman Jakobson e de Tzvetan Todorov, na USP, na "voga estruturalista da ciência-piloto e dos modelos matemáticos para as Ciências Humanas" (VOGT, 1998). Sobre sua formação, menciona: "A efervescência estruturalista e o rescaldo de maio de 68 ajudavam a desenhar os cenários de grande agitação intelectual que marcaram o início dos anos 70" (VOGT, 1998, p. 13). Era o momento de perpetuação das Ciências Humanas, que buscavam nas ciências matemáticas modelos para se afirmarem.

Sob a orientação de Jean Peytard, Vogt, na dissertação de mestrado defendida em 1971, abordou concepções da Semântica Gerativa e Interpretativa. Tendo por orientador Oswald Ducrot, na tese de doutorado, defendida em 1974, Vogt abordou as escalas argumentativas, apresentando, por objetos de análise, os enunciados comparativos, visando à formulação da Semântica Argumentativa, vinculada às descrições semânticas.

Naquele momento, início da década de 1970, estavam em voga as ideias de: Oswald Ducrot $^{88}$, Roland Barthes ${ }^{89}$, Algirdas Julius Greimas ${ }^{90}$, Antoine Culiolii ${ }^{91}$, André Martinet ${ }^{92}$, Gérard Genette $^{93}$ e Michel Foucault, em Paris (França); e de Jean-Claude Milner ${ }^{94}$ e de Nicolas Ruwet ${ }^{95}$, em Vincennes (França).

\footnotetext{
${ }^{88}$ O professor e linguista estruturalista francês Oswald Ducrot (1930- ?) foi diretor de estudos titulares na EHESS, em Paris/França, tendo também atuado como professor convidado em diversas universidades: Stuggart, Montréal, Genève e Berlin-Ouest, e, inclusive, na UNICAMP. Suas concepções foram de grande influência para a formação dos linguistas brasileiros, incluindo Geraldi.

${ }^{89}$ Roland Barthes (1915-1980), escritor, sociólogo, crítico literário, semiólogo e filósofo francês, dentre outros estudos, ficou conhecido por fazer uso da análise semiótica em revistas e propagandas, apresentando seu conteúdo político.

${ }^{90}$ Algirdas Julius Greimas (1917-1992), linguista russo, a partir de suas pesquisas, muito contribuiu para os estudos semióticos.

${ }^{91}$ Antoine Culioli, linguista francês que, dentre outras contribuições, foi responsável pela segmentação da linguagem em três faculdades: capacidades de regulação, de representação e de referenciação. Além disso, ficou conhecido também pela importância de seus estudos sobre a Teoria das Operações Enunciativas.

${ }_{92}$ Os estudos do linguista francês André Martinet (1908-1999) tiveram importante contribuição para o funcionalismo linguístico.

${ }^{93}$ Os estudos do francês Gérard Genette tiveram importante contribuição para o estruturalismo literário.

${ }^{94}$ Jean-Claude Milner (1941- ) é linguista, filósofo e ensaísta francês. Foi o tradutor pioneiro de Noam Chomsky na língua francesa.

${ }^{95}$ Nicolas Ruwet (1932-2001), linguista e crítico literário, estudou com Claude Lévi-Strauss, Noam Chomsky e Roman Jakobson.
} 
Foi exatamente dois anos após a conclusão do doutorado de Vogt, que Geraldi foi seu orientando no mestrado. As concepções estruturalistas eram, então, apresentadas ao segundo pelo primeiro, seu orientador.

Naquele momento, Geraldi inclusive traduziu o texto "As leis de discurso", publicado no livro $O$ dizer e o dito, de Ducrot, sob a revisão de Eduardo Roberto Junqueira Guimarães. Nos textos de Geraldi em que são apresentadas análises descritivas da linguagem, os textos de Vogt e de Ducrot são os mais citados.

Dessa forma, é possível considerar, nos primeiros textos de Geraldi, resquícios de uma concepção estruturalista em seu pensamento, advinda do que era estudado naquele momento na área de Linguística. No entanto, outras teorias eram acolhidas naquele momento e passaram a ser estudadas juntamente com a perspectiva estruturalista.

\subsubsection{Carlos Franchi e a perspectiva linguística gerativa}

Carlos Franchi, orientador da tese de doutorado de Geraldi, de reconhecida importância para a linguística brasileira, foi de igual importância para o reconhecimento do IEL/UNICAMP, na sociedade brasileira, como instituto de especialização e difusão da linguística.

Sua história de formação acadêmica foi construída na PUC-Campinas, na USP, na Universidade de Besançon (França) e na Universidade Aix-Marseille (França).

Assim como Geraldi, Franchi também se graduou em Ciências Jurídicas e Sociais, tendo abandonado a profissão como advogado para se dedicar ao ensino.

Foi não somente professor no IEL, mas também assumiu funções de chefia fundamentais para a difusão do conhecimento sobre linguística no Brasil.

Como anteriormente mencionado, Franchi, juntamente com Carlos Vogt, Haquira Osakabe e Rodolfo Ilari, implantaram o primeiro Departamento de Linguística do Brasil.

Ele foi um estudioso da linguística gerativa, tendo proposto reflexões sobre os estudos de Chomsky, desde a defesa de sua tese de doutorado, intitulada Hipóteses para uma teoria funcional da linguagem.

Segundo Ilari (2001),

A reflexão teórica de Carlos Franchi resultou em colocar em pauta, na lingüística brasileira, alguns temas de grande alcance e alguns problemas que ele demarcou em escritos de grande erudição e densidade como, por exemplo, as condições de possibilidade da significação e a indeterminação da linguagem, o papel criativo da linguagem e as relações entre a linguagem e a mente. (p. 2) 
Suas concepções linguísticas estavam pautadas na criatividade e na dinamicidade da linguagem, considerando-a como "atividade constitutiva" tanto dela mesma quanto do sujeito. Essas concepções se contrapunham principalmente às concepções linguísticas estruturalistas, como abordarei no Capítulo 5 desta tese.

Dessa forma, constato que o pensamento de Geraldi sobre o ensino de língua portuguesa se pautou, dentre outras concepções, nas ideias sobre linguagem de seu orientador de doutorado, principalmente quando considera o movimento característico do conhecimento, que constitui tanto a linguagem quanto o sujeito, de maneira ininterrupta.

\author{
CAPÍTULO 3 \\ APRESENTAÇÃO DA BIBLIOGRAFIA \\ DE J. W. GERALDI
}




\subsection{Bibliografia de J. W. Geraldi ${ }^{96}$}

Além de sua participação em cursos e projetos de formação de professores em todo o Brasil, a contribuição de J. W. Geraldi para o ensino de língua portuguesa é de extrema importância, tendo em vista a sua produção escrita, iniciada no final da década de 1970, no momento em que havia uma preocupação geral com novas ideias em relação às que existiam, baseadas em um "ensino tradicional". Nesse âmbito, novas propostas em relação a esse ensino emergiam, especialmente no interior do IEL.

Naquele momento, membros da CENP convidaram professores universitários do IEL/UNICAMP para escreverem textos a fim de que participassem da publicação dos Guias Curriculares. Eles buscavam respostas para os problemas da educação, dentre os quais havia a preocupação com a questão da alfabetização, cujos alunos não saíam alfabetizados da escola. Além disso, havia também os problemas de evasão e de repetência, em razão dos quais estavam sendo questionados os órgãos governamentais.

\footnotetext{
${ }^{96}$ Apresento, neste tópico, com atualizações, aspectos do instrumento de pesquisa intitulado Bibliografia de e sobre J. W. Geraldi: um instrumento de pesquisa (2009a), que teve início em 2002, por ocasião do desenvolvimento de minha pesquisa de mestrado, e que se encontra em apêndice a esta tese (Apêndice A).
} 
A partir de sua atuação, Geraldi respondia, ao mesmo tempo, às próprias indagações e também às da sociedade da época sobre o ensino de língua portuguesa quanto aos problemas relativos à falta de professores bem formados para atuar na área, dentre outros aspectos. Para essas questões, ele buscou resposta nas concepções linguísticas, “deslocando-as” para esse ensino. Para ele, faltava aos professores o conhecimento teórico sobre linguística para que as práticas em sala de aula se pautassem nas teorias que eram consideradas por eles, além da importância de o sujeito ser reconhecido como produtor de seus textos.

Em um período de 30 anos, Geraldi produziu 224 textos, como já foi mencionado anteriormente. Essa sua produção escrita ocorreu do ano de 1978, quando foram publicados seus primeiros textos: um artigo em periódico, "Algumas observações sobre o estudo da significação"; um texto em anais de eventos, "Orientação argumentativa e pressuposição", e a dissertação de mestrado intitulada Se a semântica fosse também pragmática... ou para uma análise semântica dos enunciados condicionais, até o ano de 2008, que foi determinado para o encerramento da recuperação dos documentos para a pesquisa de que resultou esta tese. Nesse último ano, Geraldi teve 12 textos publicados: "A formação de jovens diante das exigências do mercado de trabalho", "Texto e discurso: questões epistemológicas para a Lingüística", "Ler e escrever: uma mera exigência escolar?”, "Correlações entre as situações políticas e as preocupações com a língua portuguesa", "A infatigável tarefa de frear a língua", "Ingo Voese: notas biográficas \& lembranças de convívio", "Construção de uma compreensão", "Leitura: atividade humana e não apenas escolar", "Professor não pode ter medo de errar", "Os pecados da Lingüística", "Entrevista" e uma apresentação ao livro $A$ revolução bakhtiniana: o pensamento de Bakhtin e a ideologia contemporânea, de autoria de Augusto Ponzio.

No instrumento de pesquisa intitulado Bibliografia de e sobre João Wanderley Geraldi: um instrumento de pesquisa (2009a), localizado no Apêndice A desta tese, encontram-se todas as referências bibliográficas de textos de Geraldi (224 referências bibliográficas) e de textos de autores que abordaram aspectos sobre a vida e a atuação profissional de Geraldi (28 referências bibliográficas).

Como pode ser observado no Quadro 1, essas referências distribuem-se em: livros (como autor, organizador ou coordenador, co-autor): 15; capítulos de livros (como autor, coautor): 31 ; artigos em periódicos (como autor, co-autor): 64; entrevistas (como autor; como co-autor): 24; textos em anais de eventos (como autor; como co-autor): 22; artigos em jornais (como autor; como co-autor): 4; resenhas: 9; prefácios e apresentações de livros: 22; quarta 
capa e orelhas de livros: 5; traduções: 12; periódico: 1; dissertação, teses e memoriais acadêmicos: 6; e vídeos: 9 .

Quadro 1 - Bibliografia de J. W. Geraldi, por tipo de texto e forma de participação ${ }^{97}$

\begin{tabular}{|l|c|}
\hline \multicolumn{1}{|c|}{ TIPO DE TEXTO } & QUANTIDADE \\
\hline Livros & 15 \\
\hline Capítulos de livros & 31 \\
\hline Artigos em periódicos & 64 \\
\hline Entrevistas & 24 \\
\hline Textos em anais de eventos & 22 \\
\hline Artigos em jornais de notícias & 4 \\
\hline Resenhas & 9 \\
\hline Prefácios e apresentações de livros & 22 \\
\hline Quarta capa e orelhas de livros & 5 \\
\hline Traduções & 12 \\
\hline Periódico & 1 \\
\hline Dissertação, teses e memoriais acadêmicos & 6 \\
\hline Vídeos & 9 \\
\hline TOTAL & $\mathbf{2 2 4}$ \\
\hline
\end{tabular}

Fonte: Bibliografia de e sobre J. W. Geraldi: um instrumento de pesquisa (PAULA, 2009a) (Apêndice A)

${ }^{97}$ Neste quadro, foram computadas apenas as primeiras edições de cada livro publicado, exceto no caso da coletânea $O$ texto na sala de aula, em que foram computadas a edição pela Assoeste e as duas edições pela Ática: $1^{\mathrm{a}}$. edição e edição comemorativa. 
A bibliografia de Geraldi, produzida ao longo desse período, abrange, portanto, uma diversidade de tipos de texto e de tipos de autoria, pois foram publicados por ele como autor, organizador e co-autor, totalizando 17 diferentes tipos de texto/formas de participação, o que pode ser constatado no Quadro 2, por ano de publicação.

Quadro 2 - Bibliografia de J. W. Geraldi, por tipo de texto, forma de participação e ano de publicação ${ }^{98}$

98 Neste quadro, também foram computadas apenas as primeiras edições de cada livro publicado, novamente excetuando-se as edições da coletânea $O$ texto na sala de aula, em que foram apresentadas a $1^{\mathrm{a}}$. edição pela Assoeste, e a $1^{\mathrm{a}}$. edição e a edição comemorativa pela Ática. 


\begin{tabular}{|c|c|c|c|c|c|c|c|c|c|c|c|c|c|c|}
\hline $\begin{array}{l}\text { TIPO DE } \\
\text { TEXTO } \\
\text { ANO }\end{array}$ & $\begin{array}{c}\text { Livros } \\
\text { (autor/ } \\
\text { org/co } \\
\text { ord/ } \\
\text { co- } \\
\text { autor) }\end{array}$ & \begin{tabular}{|c|} 
Capítu- \\
los de \\
livros \\
(autor/ \\
co- \\
autor)
\end{tabular} & $\begin{array}{l}\text { Artigos } \\
\text { em } \\
\text { periódi- } \\
\text { cos } \\
\text { (autor/ } \\
\quad \text { co- } \\
\text { autor) }\end{array}$ & $\begin{array}{l}\text { Entre- } \\
\text { Vistas } \\
\end{array}$ & \begin{tabular}{|c} 
Textos \\
em \\
an \\
ais \\
(autor/ co- \\
autor)
\end{tabular} & \begin{tabular}{|c|}
$\begin{array}{c}\text { Arti- } \\
\text { gos em } \\
\text { jornais }\end{array}$ \\
\\
\end{tabular} & Rese & \begin{tabular}{|c} 
Prefácios \\
e apresen- \\
tações \\
(autor/co- \\
autor) \\
\end{tabular} & \begin{tabular}{|l} 
Quar- \\
ta \\
capas \\
e \\
ore- \\
lhas de \\
livros
\end{tabular} & \begin{tabular}{|l|} 
Tradu- \\
ções \\
(autor/ \\
co- \\
autor) \\
\end{tabular} & Perió- & \begin{tabular}{|l|} 
Disserta- \\
ção, \\
teses \\
e \\
memo- \\
riais \\
acadê- \\
micos \\
\end{tabular} & Vídeos & $\begin{array}{c}\text { TOTAL } \\
\text { POR } \\
\text { ANO }\end{array}$ \\
\hline 1978 & - & - & 1 & - & 1 & - & - & - & - & - & - & 1 & - & 3 \\
\hline 1979 & - & - & - & - & - & - & - & - & - & - & - & - & - & - \\
\hline 1980 & - & - & 1 & - & - & - & - & - & - & - & - & - & - & 1 \\
\hline 1981 & 1 & 1 & 3 & - & - & - & - & - & - & - & 1 & - & - & 6 \\
\hline 1982 & - & - & 1 & 1 & - & - & - & - & - & 1 & - & - & - & 3 \\
\hline 1983 & - & - & 1 & - & - & - & - & - & - & - & - & - & - & 1 \\
\hline 1984 & 1 & - & 4 & - & - & 1 & - & - & - & - & - & - & - & 6 \\
\hline 1985 & 1 & 1 & 3 & 1 & - & - & 1 & - & - & 3 & - & - & 1 & 11 \\
\hline 1986 & 1 & - & 2 & - & 2 & 1 & - & - & - & - & - & - & - & 6 \\
\hline 1987 & - & - & 1 & 2 & - & - & 3 & - & - & 1 & - & - & 1 & 8 \\
\hline 1988 & - & - & 1 & - & 4 & - & 1 & 2 & - & - & - & - & - & 8 \\
\hline 1989 & - & - & 2 & 1 & - & - & - & - & - & 1 & - & - & - & 4 \\
\hline 1990 & 1 & - & 1 & 1 & - & - & - & - & - & 2 & - & 1 & - & 6 \\
\hline 1991 & 1 & 2 & 1 & - & 1 & - & - & 1 & - & - & - & - & 2 & 8 \\
\hline 1992 & - & - & 2 & - & 1 & - & - & - & - & 1 & - & - & 2 & 6 \\
\hline 1993 & - & - & 2 & 1 & - & - & 1 & 1 & - & - & - & - & - & 5 \\
\hline 1994 & 1 & 2 & 2 & 2 & 3 & - & - & - & - & - & - & - & - & 10 \\
\hline 1995 & - & 1 & 3 & 1 & 1 & 2 & - & - & 1 & - & - & 2 & - & 11 \\
\hline 1996 & 1 & - & 4 & 1 & 2 & - & - & - & 1 & - & - & - & - & 9 \\
\hline 1997 & 2 & - & 3 & 1 & 1 & - & - & 1 & 1 & 1 & - & - & - & 10 \\
\hline 1998 & - & - & - & 1 & - & - & - & - & - & - & - & - & - & 1 \\
\hline 1999 & - & 3 & 1 & 1 & - & - & - & 1 & - & - & - & 1 & - & 7 \\
\hline 2000 & - & 1 & 3 & - & 2 & - & - & - & - & - & - & - & - & 6 \\
\hline 2001 & - & 1 & 1 & 1 & - & - & - & 5 & - & 1 & - & - & - & 9 \\
\hline 2002 & - & - & 3 & - & - & - & 1 & 2 & 2 & 1 & - & 1 & - & 10 \\
\hline
\end{tabular}




\begin{tabular}{|c|l|l|l|l|l|l|l|l|l|l|l|l|l|c|}
\hline $\mathbf{2 0 0 3}$ & - & 5 & 2 & 1 & 1 & - & 1 & 4 & - & - & - & - & - & $\mathbf{1 4}$ \\
\hline $\mathbf{2 0 0 4}$ & 2 & 3 & 3 & 1 & 2 & - & 1 & 1 & - & - & - & - & - & $\mathbf{1 3}$ \\
\hline $\mathbf{2 0 0 5}$ & 1 & - & 1 & 1 & - & - & - & 2 & - & - & - & - & - & $\mathbf{5}$ \\
\hline $\mathbf{2 0 0 6}$ & 2 & 4 & 3 & 1 & - & - & - & - & - & - & - & - & - & $\mathbf{1 0}$ \\
\hline $\mathbf{2 0 0 7}$ & - & 2 & 7 & 1 & 1 & - & - & 1 & - & - & - & - & 3 & $\mathbf{1 5}$ \\
\hline $\mathbf{2 0 0 8}$ & - & 5 & 2 & 4 & - & - & - & 1 & - & - & - & - & - & $\mathbf{1 2}$ \\
\hline $\begin{array}{c}\text { Total por } \\
\text { tipo } \\
\text { de texto }\end{array}$ & $\mathbf{1 5}$ & $\mathbf{3 1}$ & $\mathbf{6 4}$ & $\mathbf{2 4}$ & $\mathbf{2 2}$ & $\mathbf{4}$ & $\mathbf{9}$ & $\mathbf{2 2}$ & $\mathbf{5}$ & $\mathbf{1 2}$ & $\mathbf{1}$ & $\mathbf{6}$ & $\mathbf{9}$ & $\mathbf{2 2 4}$ \\
\hline
\end{tabular}

Fonte: Bibliografia de e sobre J. W. Geraldi: um instrumento de pesquisa (PAULA, 2009a) (Apêndice A)

Com relação aos textos publicados por Geraldi, dentre os 15 livros, três foram publicados como autor: Portos de passagem (1991a), Linguagem e ensino: exercícios de militância e divulgação (1996a) e A aula como acontecimento (2004); quatro, como organizador/coordenador: O texto na sala de aula: leitura \& produção (1984), O texto na sala de aula (1997), Aprender e ensinar com textos de alunos (1997) e O texto na sala de aula (2005); e oito como co-autor: Sobre a estruturação do discurso (1981), com Eni Pulcinelli Orlandi, Sírio Possenti" ${ }^{99}$, Eduardo J. Guimarães e Jesus Antonio Durigan; Semântica (1985), com Rodolfo Ilari; O ensino de língua portuguesa no $1^{\circ}$. grau: projeto magistério (1986), com Lilian Lopes Martins da Silva, Sarita Moysés e Raquel Salek Fiad; Paulo Freire: trabalho, comentário, reflexão (1990), com Adriano Nogueira; e a versão, para o espanhol, desse último livro, sob o título Paulo Freire: una reflexión sobre la educación, administración y política en el município de São Paulo, Brasil (1994); Diálogos através de Paulo Freire (2004), com Luiza Cortesão, Rosa Nunes, Abreu Freire, Rui Trindade e José Eustáquio Romão; Janelas para o mundo: diálogo com outras vozes $(2006)^{100}$, com Bernd Fichtner ${ }^{101}$, Carlos

\footnotetext{
${ }^{99}$ Segundo dados que constam no currículo do Sistema de Currículos Lattes, consultado em 24 de novembro de 2009, Sírio Possenti é atualmente professor livre-docente associado no departamento de Linguística do IEL/UNICAMP, atuando na área de Linguística, e na sub-área de Análise do Discurso.

100 Esse livro resultou de atividades desenvolvidas por intermédio do Projeto "Janelas para o mundo", desenvolvido por pesquisadores da Universidade de Siegen/Alemanha, da UNICAMP e da Secretaria Municipal de Cuiabá, dentre eles, Geraldi. O principal objetivo do Projeto visava ao conhecimento da utilização da internet em diferentes culturas. Maiores informações constam no site $w w w$.janelasparaomundo.org.

${ }^{101}$ Bernd Fichtner é professor titular da Faculdade de Educação da Universität Siegen e diretor do International Education Doctorade Program (INEDD).
} 
Maldonado $^{102}$, Lurdi Haas ${ }^{103}$, Corinta Maria Grisólia Geraldi ${ }^{104}$, Clemens Knobloch ${ }^{105}$, Afira V. Ripper ${ }^{106}$, Joseane Zaghetti ${ }^{107}$, Maria Florentina A. Camerini ${ }^{108}$, Sandra Leibovici ${ }^{109}$, Maria Benites $^{110}$, Amauri Lobo ${ }^{111}$, Eunice Cesnik $^{112}$ e Alessandra Vidotti ${ }^{113}$; e Transgressões convergentes: Vigotski, Bakhtin, Bateson (2006), com Bernd Fichtner e Maria Benites.

Dentre os 31 capítulos de livros publicados, 29 deles foram publicados como autor, e dois, como co-autor.

Como autor, foram publicados os seguintes capítulos de Geraldi: “Tópico-comentário e orientação argumentativa" (1981), "Linguagem e ação" (1991), “O professor como leitor do texto do aluno" (1991), "Trabalho com a linguagem e história da educação na rede de ensino" (1994), "Uma reflexão interdisciplinar a partir da análise lingüística de um texto produzido por um aluno" (1994), “A leitura em momento de crise social” (1995), "Paulo Freire: narrador e pensador" (1999), "Professor, militante e pensador" (1999), "Da sala de aula à construção externa da aula" (1999), "Linguagem, cultura e educação: a formação científica de profissionais educadores" (2000), "Notas sobre a exclusão da língua geral e a introdução da língua portuguesa" (2001), "Paulo Freire e Mikhail Bakhtin: o encontro que não houve" (2003), “A diferença identifica. A desigualdade deforma. Percursos bakhtinianos de construção ética e estética" (2003), "A linguagem nos processos sociais de constituição da subjetividade" (2003), "Conteúdos de ensino e conteúdos escolares: em defesa de uma escola de sistematização de conhecimentos produzidos pelas práticas sociais" (2003), "Convívio paradoxal com o ensino da leitura e escrita" (2003), "Depois do show, como encontrar

\footnotetext{
${ }^{102}$ Carlos Maldonado foi secretário de Educação do Município de Cuíba/MT. É professor da UNEMAT e cursou doutorado na Universität Siegen/Alemanha.

${ }^{103}$ Lurdi Haas, advogada, é diretora da escola Municipal "Rita Caldas", da Secretaria Municipal de Cuiabá/MT. Foi coordenadora do Projeto "Janelas para o mundo", no estado de Mato Grosso.

${ }^{104}$ De acordo com informações de seu currículo, as quais constam no Sistema de Currículos Lattes, consultado em 20 de novembro de 2009, Corinta Maria Grisólia Geraldi, esposa de Geraldi, atua desde 1981 na FE/UNICAMP, onde cursou mestrado e doutorado. Corinta Geraldi atua nas seguintes áreas: "Ensino-pesquisa", "Trabalho docente" e "Currículo em ação".

${ }^{105}$ Clemens Knobloch é professor titular da Faculdade de Letras e Literatura da Universität Siegen/Alemanha. Atua na área de Teoria da Linguagem, Análise do Discurso, Linguística Aplicada e Comunicação.

${ }^{106}$ Afira Vianna Ripper é professora titular da FE/UNICAMP. Fundou o Laboratório de Educação e Informática Aplicada (LEIA) da FE/UNICAMP.

${ }^{107}$ Joseane Zaghetti é assistente da professora Afira Vianna Ripper e bolsista FAPESP no LEIA.

${ }^{108}$ Maria Florentina A. Camerini, doutora em Psicologia do Desenvolvimento pela PUC/RJ, é coordenadora de projetos de pesquisa no Instituto Vigotski no Rio de Janeiro e colaboradora de pesquisas sociais da PUC/RJ.

${ }^{109}$ Sandra Leibovici, formada em Comunicação Social pela USP, coordenou o Projeto "Janelas para o mundo", no ano de 2005, pelo Instituto Vigotski.

${ }^{110}$ Maria Benites atua como coordenadora do INEDD, na Universität de Siegen/Alemanha. Atua também como diretora internacional do Instituto Vigotski.

${ }^{111}$ Amauri Lobo, artista, formado em Ciências Sociais, realizou doutorado no INEDD, na Universität Siegen, na Alemanha.

112 Eunice Cesnik, vice-presidente do Instituto Vigotski, é formada em Matemática pela PUC/SP e tem especialização em Pedagogia e Psicopedagogia.

${ }^{113}$ Alessandra Vidotti, formada em Letras pela USP, é coordenadora do Projeto “Janelas para o mundo".
} 
encantamento?" (2004), "Alteridades: espaços e tempos de instabilidades" (2004), "Paulo Freire e Mikhail Bakhtin: o encontro que não houve" (2004), "A presença do texto na sala de aula" (2006), “Alfabetizações cotidianas: as letras da cidade e a cidade das letras”(2006), “É possível investir nas enunciações, sem as garantias dos enunciados já firmados?”(2006), “Alterität: räume und Zeiten der Instabilität" (2007); "Leitura: uma oferta de contrapalavras" (2007), “A formação de jovens diante das exigências do mercado de trabalho"(2008), "Texto e discurso: questões epistemológicas para a Lingüística" (2008), "Ler e escrever: uma mera exigência escolar?”(2008), “Correlações entre as situações políticas e as preocupações com a língua portuguesa" (2008) e “A infatigável tarefa de frear a língua”(2008).

Dois capítulos de livro de Geraldi foram publicados como co-autor: "Argumentative operators and dialogue" (1985), com Eduardo Roberto Junqueira Guimarães e Rodolfo Ilari; e "Tecnologias na escola, tecnologias da escola" (2006), com Corinta Maria Grisólia Geraldi.

Dos 64 textos de Geraldi, publicados como artigos em periódicos, 53 foram publicados como autor, e 11, como co-autor.

Os artigos publicados como autor foram: "Algumas observações sobre o estudo da significação" (1978); "Notas para uma tipologia lingüística dos períodos hipotéticos" (1981); “Ensino da língua ou ensino da metalinguagem?” (1981); “Unidades básicas do ensino de língua portuguesa"(1981); "Possíveis alternativas para o ensino de língua portuguesa" (1982); “O circuito do livro e a escola"(1983), publicado também no ano seguinte; "Formas de expressão de condição e hipóteses"(1984); "Prática da leitura de textos na escola" (1984), publicado em dois periódicos no mesmo ano; "Escrita, uso da escrita e avaliação" (1985); “Aprende-se a escrever escrevendo" (1985), publicado também em 1987; "Prática de produção de textos na escola”(1986); "Aprende-se a escrever escrevendo" (1987); "A leitura na sala de aula: as muitas faces de um leitor" (1988); "Educação e linguagem" (1989); “Texto: um problema para o exercício da capatazia" (1989), publicado também no ano seguinte; “O ensino e as diferentes instâncias de uso da linguagem” (1992); “A constituição do sujeito leitor" (1992); "Ensino de gramática x reflexão sobre a língua" (1993); “Cadernos de estudos lingüísticos: 20 números depois" (1993); "Construção de um novo modo de ensinar e de aprender a língua portuguesa" (1994); "Português: o aprendizado que vem da vida do próprio aluno" (1994); “A produção do texto escolar: processos e produtos” (1995); “Abordagem sócio-interacionista no ensino, leitura e escrita" (1996); "Descrição da língua e ensino da língua” (1996); “Convívio paradoxal com o ensino da leitura e escrita” (1996); “A prática escolar sob escrutínio" (1997); "Paulo Freire: narrador e pensador" (1997); “O uso como lugar de construção dos recursos lingüísticos" (1997); “Culturas orais em sociedades 
letradas" (2000), publicado em dois periódicos no mesmo ano; "Palavras escritas, indícios de palavras ditas" (2000); "A linguagem nos processos sociais de constituição da subjetividade" (2001); "Culturas orais e língua escrita: três retratos três por quatro" (2002); "Leitura: uma oferta de contrapalavras" (2002); “Depois do 'show', como encontrar encantamento?” (2003), também publicado no ano seguinte; "Palavras escritas, indícios de palavras ditas" (2003); "A linguagem em Paulo Freire" (2005); "Pesquisa em linguagem na contemporaneidade" (2006); "Há funções para o ensino escolar da gramática?" (2006); "Pesquisa em linguagem na contemporaneidade" (2007); “Alteridades: espaços e tempos de instabilidades" (2007); "Mensagem aos leitores que vão nascer" (2007); "O paradoxo aplicado" (2007); “Essencialidades" em Paulo Freire: ser, falar e conhecer" (2007); "Problematizar o futuro não é perder a memória do que há de vir" (2007); "Mediações pedagógicas no processo de produção de textos" (2007); "Ingo Voese: notas biográficas \& lembranças de convívio" (2008); e "Construção de uma compreensão" (2008).

Como co-autor, foram publicados 10 artigos, a saber: "Caracterização sumária dos sujeitos falantes no mundo imaginário de Walt Disney” (1980), com Celene Margarida Cruz; “Operadores de argumentação e diálogo" (1985), com Eduardo Roberto Junqueira Guimarães e Rodolfo Ilari; “O livro didático de língua portuguesa: didatização e destruição da atividade lingüística” (1986), com Eliana M. Ruiz, Raquel Salek Fiad e Lilian Lopes Martin da Silva; “Considerações sobre a utilização de um paradigma indiciário na análise de episódios de refacção textual” (1995), com Maria Bernadete Abaurre, Maria Laura T. Mayrink Sabinson e Raquel Salek Fiad; “A circulação escolar de textos produzidos por alunos” (1995), com Beatriz Helena Marão Citelli, Conceição Aparecida de Jesus, Claudinéia Barbosa de Azevedo, Elisa Duarte Teixeira, Maria Madalena Iwamoto Sercundes e Marlete Carboni Tardeli; "Lingüística, ensino de língua materna e formação de professores" (1996), com Lilian Lopes Martin da Silva e Raquel Salek Fiad; "Educação continuada: a política da descontinuidade" (1999), com Cecília Azevedo Lima Collares e Maria Aparecida Affonso Moysés; "As aventuras do conhecer: da transmissão à interlocução" (2002), com Cecília Azevedo Lima Collares e Maria Aparecida Affonso Moysés; “Avaliação: gestos necessários" (2004), com Corinta Maria Grisolia Geraldi; "Percursos de consolidação da didáctica de línguas em Portugal: análise dos estudos realizados no âmbito das unidades de investigação científica, subsidiadas pela Fundação para a Ciência e Tecnologia, na área das ciências da educação" (2004), com Isabel Alarcão, Ana Isabel Andrade, Antonio Moreira, Cristina Manuela Sá, Luísa Álvares Pereira, Manuel Bernardo Canha, Maria Helena Ançã, Maria Helena Araújo e Sá, Teresa Cardoso, Mário Gamito e Susana Pinto; e "Compaginar 
concepções: ciência e formação no horizonte de possibilidades de um projeto coletivo" (2006), com Cecília Azevedo Lima Collares e Maria Aparecida Affonso Moysés ${ }^{114}$.

Dentre os 24 textos publicados como entrevistas, 20 foram publicados como autor, e quatro, como co-autor. As entrevistas publicadas como autor foram: "Educação na parede" (1985), "Método se baseia na produção de textos" (1987), "Livro didático de língua portuguesa: a favor ou contra?" (1987), "São-luizense aprovado com distinção e louvor em tese de doutorado" (1990), "A linguagem reflete a pobreza cultural" (1993), "Repensando o curso de Letras" (1994), "Carreira em debate" (1995), "Em defesa do acesso ao mundo da escrita" (1996), "Prof. Wanderley Geraldi, diretor do IEL, fala ao SAS" (1997), "Recuperando as práticas de interlocução na sala de aula" (1998), "Aos mestres, a leitura" (1999), “Trajetória com ética e genialidade" (2001), “João Wanderley Geraldi” (2003), "Entrevista sobre $O$ texto na sala de aula: leitura \& produção" (2004), "Um bom professor ensina a perguntar" (2006), "A linguagem nos processos sociais de constituição da subjetividade" (2007), "Leitura: atividade humana e não apenas escolar" (2008), "Professor não pode ter medo de errar" (2008), "Os pecados da Lingüística" (2008) e "Entrevista" (2008).

Como co-autor, as quatro entrevistas publicadas foram: "O efeito das palavras" (1982), com Haquira Osakabe, Jonas de Araújo Romualdo e Sírio Possenti; "Para repensar o ensino de português" (1989), com Raquel Salek Fiad e Lílian Lopes Martin da Silva; "A sala de aula é uma oficina de dizer coisas" (1994), com Raquel Salek Fiad; e "Leitura e escrita na escola podem ser livres?” (2005), com Corinta Geraldi, Victoria Carbó ${ }^{115}$, Carla Mauch ${ }^{116}$, Tomás González ${ }^{117}$, Vera González ${ }^{118}$, Fernando González ${ }^{119}$, Miréia Larrosa ${ }^{120}$ e Jorge Larrosa $^{121}$.

\footnotetext{
${ }^{114}$ De acordo com informações de seu currículo, as quais constam no Sistema de Currículos Lattes, consultado em 20 de novembro de 2009, Maria Aparecida Affonso Moysés atua desde 1985 até os dias atuais na Faculdade de Ciências Médicas/UNICAMP. É professora titular de Pediatria Social na UNICAMP desde 2003.

${ }^{115}$ Segundo informações que constam na revista Presença pedagógica, Victoria Carbó é espanhola, professora de música e companheira de Fernando González, sociólogo da Universidade de Barcelona.

${ }^{116}$ Carla Mauch é professora do Instituto de Filosofia e Ciências Humanas, da UFRGS.

${ }^{117}$ Tomás González é filho de Fernando González e Victoria Carbó, e irmão de Vera González. No momento da entrevista, contava com 7 anos e estava no correspondente ao nosso terceiro ano do Ensino Fundamental de uma escola primária de Barcelona/Espanha.

${ }^{118}$ Vera González, também segundo informações que constam na revista Presença pedagógica, é filha de Fernando González e Victoria Carbó. No momento da entrevista, contava com 10 anos e era estudante do correspondente quinto ano do nosso Ensino Fundamental numa escola de Barcelona/Espanha.

${ }^{119}$ Fernando González é sociólogo da Universidade de Barcelona/Espanha.

${ }^{120}$ No momento da entrevista, Miréia Larrosa contava com nove anos e era estudante do que corresponde ao nosso quarto ano do Ensino Fundamental, em uma escola pública de Barcelona, de acordo com informações que constam na revista Presença pedagógica. Ela participou da entrevista por indicação do pai, Jorge Larrosa.

${ }^{121}$ Jorge Larrosa Bondia, doutor em Filosofia da Educação, é professor da Universidade de Barcelona/Espanha.
} 
Dentre os 22 textos de Geraldi publicados em anais de eventos, 15 foram publicados como autor, e sete, como co-autor. Os textos em anais de eventos publicados como autor, foram: "De como produzir milagres ou o professor pega um boizinho, rifa e compra livros" (1986), "Prática de produção de textos na escola" (1986), "Cinco questões sobre a questão dos métodos" (1988), “A propósito do outro: imagem, construção e cumplicidade” (1991), “Ainda e sempre: leitura" (1992), "A escrita como trabalho: operações e meta-operações de construção de textos" (1994), "Políticas de inclusão em estruturas de exclusão" (1994), "Linguagem, subjetividade e ensino de língua estrangeira" (1996), "A prática escolar sob escrutínio" (1996), "Da produção do texto escolar" (1997), "Sobre a constituição dos objetos de ensino em língua materna" (2000), “A complexa construção de um campo de estudos: subsídios para uma discussão sobre educação lingüística” (2003), “A linguagem em Paulo Freire" (2004), "Problematizar o futuro não é perder a memória do que há de vir" (2004) e “Texto e discurso: questões epistemológicas para a Lingüística" (2007).

Como co-autor, foram publicados os seguintes textos em anais de eventos: "Orientação argumentativa e pressuposição" (1978), com Celene Margarida Cruz; “Cancelador de implicatura x operador argumentativo: análise da partícula 'hoaga' do Pirahã” (1988), com Maria Filomena Spatti Sândalo; “A interlocução no debate político” (1988), com Jonas A. Romualdo, Sírio Possenti e Haquira Osakabe; "Nem: operador argumentativo?" (1988), com Liliane Moreira; “O caráter singular das operações de refacção nos textos representativos do início da aquisição da escrita” (1995), com Raquel Salek Fiad, Maria Bernadete M. Abaurre, Maria Laura Trindade Mayrink-Sabinson; “A circulação de textos na escola: primeiros resultados” (1995), com Lígia Chiappini, Guaraciaba Micheletti e Adilson Citelli; "A integração disciplinar pelo foco das práticas educativas: uma proposta curricular para um programa de mestrado" (2000), com Cecília L. Collares e Maria Aparecida Affonso Moysés.

Como artigos em jornais de notícias, ao todo quatro, três foram publicados como autor, e um, como co-autor. Como autor, foram publicados: "Eça de Queiroz, a língua padrão, o ensino e quejandos outros" (1984), "Aos que resistem, a exigência do novo tempo" (1995) e "Leitura, objeto de incentivo e repressão" (1995); e, como co-autor: "A destruidora didática dos livros" (1986), com Eliana Maria Ruiz, Lílian Lopes Martins da Silva e Raquel Salek Fiad.

Dentre os textos de Geraldi publicados como resenhas de livros, nove ao todo, oito foram publicados como autor, e um, como co-autor. As resenhas publicadas como autor foram: do livro A lingüistica e o ensino da língua portuguesa, de Rodolfo Ilari, em 1985; do 
livro Manual de tapeçaria, de Nilma Gonçalves Lacerda, em 1987; do Dicionário prático de regência verbal, de Celso Pedro Luft, intitulada "Útil, mas prescindível”, em 1987; do livro Nem tudo é poesia, de Mestre David, intitulada "Breve nota sobre as notas de Mestre David", em 1988; do livro Nos bastidores da comunicação autêntica, de Patrícia Hilda Franzoni, intitulada "Autenticidade x artificialidade no ensino de línguas", em 1994; do livro Viva a tese! Um guia de sobrevivência, de Maria Ester de Freitas, em 2002; resenha intitulada Destaques bibliográficos, em 2003; e do livro Método, métodos, contramétodo, de Regina Leite Garcia, intitulada "Pelos caminhos e descaminhos dos métodos”, em 2004.

Como co-autor, teve publicada a resenha do livro No mundo da escrita: uma perspectiva psicolingüística, de Mary A. Kato, em 1987, com Maria Laura Mayrink Sabinson.

Geraldi teve publicados também 14 prefácios e oito apresentações de livros, perfazendo um total de 22.

Com relação aos prefácios, foram publicados: "O ensino é livresco, mas sem livros", ao livro Elementos de pedagogia da leitura, de Ezequiel Teodoro da Silva, de 1988; ao livro A escrita e o outro, de Lucília Helena do Carmo Garcez, de 1988; ao livro Fugindo da norma, de Luiz Percival Leme Britto, de 1991; “Trouxeste a chave?”, ao livro Em sobressaltos: formação de professora, de Maria do Rosário Mortatti Magnani, de 1993; "Da redação à produção de textos", ao livro Aprender e ensinar com textos de alunos, de Geraldi e Beatriz Citelli, de 1997; ao livro Autocorreção e auto-avaliação na produção de textos escolares, de Gláucia Muniz Proença Lara, de 1999; "Sagacidade, argúcia e lupa”, ao livro Introdução à Semântica: brincando com a gramática, de Rodolfo Ilari, de 2001; “Ser esta metamorfose ambulante", ao livro A institucionalização invisivel: crianças que não-aprendem-na-escola, de Maria Aparecida Affonso Moysés, de 2001; "Pela mão de Graciliano", ao livro Um ensaio sobre a formação da subjetividade na psicologia sócio-histórica, de Taísa Viliese de Lemos, de 2002; "Recuperar memórias silenciadas", ao livro A invenção da palavra oficial: identidade, língua nacional e escola em tempos de globalização, de Andréa de Beremblun, de 2003; “A arte de formular perguntas", ao livro Questões sobre questões de leitura, de Rosa Maria Nery, de 2003; "Saberes da lida, saberes da vida", ao livro Sentidos do trabalho: a educação continuada de professores, de Maria Emília Caixeta de Castro Lima, de 2005; "Coragem dos gestos de encontro", ao livro Nada sobre nós sem nós: a centralidade da comunicação na obra de Boaventura de Sousa Santos, de Rosa Soares Nunes, de 2005; "Desdobramentos do móvel", ao livro Entre a reflexão e a prática, organizado por Ana Cristina Fricke Matte, de 2007. 
Quanto às apresentações, foram, ao todo, oito: ao livro Produção e leitura de textos no ensino fundamental, de Beatriz Citelli, de 2001; à coletânea Redações do Vestibular da UNICAMP, de 2001; em co-autoria com Sírio Possenti, ao livro Análise do discurso: uma leitura e três enfoques, de Iracema Gabler, Nair Gurgel e Tânia Rocha Parmigiani, de 2001; "Para tecer um amanhã", ao livro $O$ ensino da língua materna: interações em sala de aula, de Marlette Carboni Tardelli, de 2002; "Liberar gestos travados", ao livro Palavra de professor (a): tateios e reflexões na prática da pedagogia Freinet, organizado por Gláucia de Melo Ferreira, de 2003: ao livro Voz do Professor, publicado pela Fundação Itaú Social/CENPEC, de 2003; ao livro Análise do Discurso e o ensino de língua portuguesa, de Ingo Voese, de 2004; ao livro $A$ revolução bakhtiniana: o pensamento de Bakhtin e a ideologia contemporânea, de Augusto Ponzio, de 2008.

Quanto aos textos de Geraldi publicados como quarta-capa e orelhas de livros, foram cinco: quatro quarta-capas e uma orelha de livro. Com relação às quarta-capas, foram elas: do livro A língua portuguesa no coração de uma nova escola, de Regina Lúcia F. Miranda, Pensilvânia D. G. Santos e Nilma G. Lacerda, publicado em 1995; do livro Histórias de professores, organizado por Sônia Kramer e Solange Jobim e Souza, publicado em 1996; do livro Inconfidência mineira: a história dos sentidos de uma história, de Júnia Diniz Focas, publicado em 2002; do livro Nas telas da mídia, organizado por Maria Inês Ghilardi e Valdir Heitor Barzotto, publicado em 2002. E a orelha do Acervo Certas Palavras - Programas de livros e idéias, publicado em 1997.

Dentre os textos publicados como tradução, foram 12: oito como autor, e quatro como co-autor. Os textos publicados como autor foram: "Lógica e conversação" (1982), de H. Paul Grice; “A paráfrase lingüística: equivalência, sinonímia ou reformulação?” (1985), de Catherine Fuchs; "O que é uma força ilocucionária?” (1985), de Daniel Vanderveken; “Ao inferno com a teoria dos atos de fala" (1985), de Georg Meggle; "As leis de discurso" (1987), de Oswald Ducrot; "O antônimo e o pronome em francês moderno e a forma e o sentido na linguagem” (1989), de Émile Benveniste; “O aprendizado do novo: reflexões sobre a tragédia do começo" (2001), de Fernando Bárcena Orbe; "Nota sobre a experiência e o saber da experiência" (2002), de Jorge Larrosa Bondia. Quanto às traduções publicadas como co-autor, foram elaboradas com Celene Margarida Cruz: "Heterogeneidade(s) enunciativa(s)" (1990), de Jacqueline Authier-Revuz; "Construções relativas e articulações discursivas" (1990), de Paul Henry; e "Crítica textual e história cultural: o texto e a voz, séculos XVI-XVII" (1997), de Roger Chartier; e em co-autoria com Jonas de Araújo Romualdo, a tradução do texto "Código, uso e fundamentos" (1992), de Marcelo Dascal. 
Geraldi teve um periódico publicado, intitulado "Subsídios metodológicos para o ensino de língua portuguesa: $5^{\mathrm{a}}$. a $8^{\mathrm{a}}$. séries" (1981), no qual foram publicados dois artigos.

Quanto aos textos publicados como dissertação, teses e memoriais acadêmicos, foram seis, ao todo: a dissertação Se a semântica fosse também pragmática... ou para uma análise semântica dos enunciados condicionais (1978); a tese Linguagem, interação e ensino (1990); a tese de livre-docência, Exercícios de militância e divulgação (1995); o Memorial: 1946 1994 (1995); o Memorial: janeiro de 1995 a abril de 1999 (1999); e o Memorial: maio de 1999 a abril de 2002 (2002).

Em vídeos, Geraldi teve nove participações: “Língua Portuguesa 1” (1985), “O desafio da leitura e a contribuição da literatura infantill" (1987), "Palavra de leitor" (1990), "Questões do ensino de língua: leitura, gramática e produção de textos" (1991), "Língua portuguesa" (1992), "Leitura \& Escola" (1992), "A linguagem nos processos sociais de constituição da subjetividade" (2007), "A importância do texto na sala de aula 1" (2007) e "A importância do texto na sala de aula 2" (2007).

Três textos de Geraldi foram publicados em língua estrangeira - um como autor e dois como co-autor: o capítulo de livro "Alterität: Räume und Zeiten des Instabilität: vom umgang mit differenz" (2007), em língua alemã; o capítulo de livro "Argumentative operators and dialogue" (1985), em parceria com Eduardo R. J. Guimarães e Rodolfo Ilari, em língua inglesa; e o livro Paulo Freire: una reflexión sobre la educación, administración y política en el município de São Paulo, Brasil (1994), em parceria com Adriano Nogueira, em língua espanhola.

Em outros países, foram publicados 13 textos de Geraldi. Em português, foram publicados: dois livros, um capítulo de livro, quatro artigos em periódicos e três textos em anais de eventos, estes em Portugal; em espanhol, um livro no Chile; em inglês, um capítulo de livro nos Estados Unidos da América; e em alemão, um capítulo de livro na Alemanha.

Quanto ao maior número de textos, foram publicados 15 no ano de 2007; 14 no ano de 2003; e 13 no ano de 2004. Em 1979, não houve publicações. E nos anos de 1980, 1983 e 1998, houve a publicação de apenas um texto por ano.

Considerando a publicação por décadas, tem-se: na década de 1970, três textos; na década de 1980, 54 textos; na década de 1990, 73 textos; na década de 2000, 94 textos, como apresento no Quadro 3. 


\begin{tabular}{|c|c|}
\hline DÉCADA & $\begin{array}{c}\text { NUMERO DE TEXTOS } \\
\text { PUBLICADOS }\end{array}$ \\
\hline 1970 & 3 \\
\hline 1980 & 54 \\
\hline 1990 & 73 \\
\hline 2000 & 94 \\
\hline $\begin{array}{c}\text { TOTAL DE TEXTOS } \\
\text { PUBLICADOS }\end{array}$ \\
\hline
\end{tabular}

Fonte: Bibliografia de e sobre J. W. Geraldi: um instrumento de pesquisa (PAULA, 2009a) (Apêndice A)

Com relação ao número de textos, a publicação de textos de Geraldi ocorreu em uma escala progressiva do final da década de 1970 até a década atual, tendo em vista o momento histórico e as solicitações da sociedade da época para que os pesquisadores publicassem os resultados de suas pesquisas, conforme a política acadêmica do momento.

A ocorrência de um menor número de textos publicados nas primeiras décadas de atuação de Geraldi explica-se, em parte, pela divulgação de sua proposta para o ensino de língua portuguesa, naquele momento, e também por sua atuação em projetos sobre o ensino.

No final da década de 1970, Geraldi iniciou o mestrado na UNICAMP e também suas publicações; na década de 1980, ocorreu uma intensa divulgação de sua proposta em todo o país; na década de 1990, estavam sendo publicados, pelo Ministério da Educação, tanto a Lei de Diretrizes e Bases da Educação Nacional (1996), quanto os Parâmetros Curriculares Nacionais: língua portuguesa $(1997)^{122}$, momento em que foram oficializadas algumas concepções vinculadas a propostas para o ensino da língua portuguesa, dentre elas, a de Geraldi $^{123}$.

Com relação aos textos de Geraldi publicados sob o mesmo título, excetuando-se a coletânea $O$ texto na sala de aula, que teve uma edição pela ASSOESTE, e duas edições, pela Ática, 13 textos de Geraldi foram publicados mais de uma vez sob o mesmo título: "Alteridades: espaços e tempos de instabilidades" e "Depois do show, como encontrar encantamento?" foram publicados três vezes, duas vezes como artigos, em diferentes periódicos, e uma vez como capítulo de livro; os outros 11 textos de Geraldi foram publicados

\footnotetext{
${ }^{122}$ Nos Parâmetros Curriculares Nacionais: língua portuguesa, é citado, na página 38, o livro Portos de passagem (1991), de Geraldi, fazendo referência aos termos: "análise lingüística", "atividade epilingüística" e "atividade metalingüística", tal como os propõe Geraldi nesse livro.

${ }^{123}$ Nos Parâmetros Curriculares Nacionais: língua portuguesa, são citados dois livros de sua autoria: $O$ texto na sala de aula e Portos de passagem, e um livro em co-autoria com Lígia Chiappini: Aprender e ensinar com textos dos alunos. Além disso, há a seguinte nota de rodapé com menção a Geraldi: "Os termos 'análise lingüística', 'atividade epilingüística' e 'atividade metalingüística' são utilizados aqui como propostos por João Wanderley Geraldi, no livro Portos de passagem” (p. 38).
} 
duas vezes sob o mesmo título - sete deles sob o mesmo tipo de texto: "Paulo Freire e Mikhail Bakhtin: o encontro que não houve", como capítulos de livros; "O circuito do livro e a escola", "Prática da leitura de textos na escola", "Aprende-se a escrever escrevendo", "Texto: um problema para o exercício da capatazia", "Culturas orais em sociedades letradas" e "Pesquisa em linguagem na contemporaneidade", como artigos em periódicos; e quatro textos, sob diferentes formas de publicação: "Prática de produção de textos na escola" e "A prática escolar sob escrutínio", sob a forma de textos em anais de eventos e artigos em periódicos; e "Paulo Freire: narrador e pensador" e "A linguagem nos processos sociais de constituição da subjetividade" ${ }^{124}$, como capítulos de livros e artigos em periódicos.

No Quadro 4, apresento a ocorrência dos textos de Geraldi publicados com o mesmo título, sob a forma de: artigos em periódicos, capítulos de livro e textos em anais de eventos.

\section{Quadro 4 - Textos de Geraldi publicados sob o mesmo título, por ocorrência de tipos de textos}

\begin{tabular}{|c|c|c|c|c|c|}
\hline $\begin{array}{l}\text { OCOR- } \\
\text { RÊNCIA }\end{array}$ & TEXTO & $\begin{array}{l}\text { EM ARTIGOS } \\
\text { EM } \\
\text { PERIÓDICOS }\end{array}$ & $\begin{array}{l}\text { EM } \\
\text { CAPÍTULOS DE } \\
\text { LIVRO }\end{array}$ & $\begin{array}{l}\text { EM TEXTOS } \\
\text { EM ANAIS DE } \\
\text { EVENTOS }\end{array}$ & TOTAL \\
\hline 1 & $\begin{array}{c}\text { "Alteridades: espaços e tempos de } \\
\text { instabilidades" }\end{array}$ & 2 & 1 & - & 3 \\
\hline 2 & $\begin{array}{l}\text { "Depois do show, como encontrar } \\
\text { encantamento?" }\end{array}$ & 2 & 1 & - & 3 \\
\hline 3 & $\begin{array}{l}\text { "Paulo Freire e Mikhail Bakhtin: o } \\
\text { encontro que não houve" }\end{array}$ & - & 2 & - & 2 \\
\hline 4 & $\begin{array}{c}\text { "O circuito do livro } \\
\text { e a escola" }\end{array}$ & 2 & - & - & 2 \\
\hline 5 & $\begin{array}{c}\text { "Prática da leitura de textos na } \\
\text { escola" }\end{array}$ & 2 & - & - & 2 \\
\hline 6 & $\begin{array}{l}\text { "Aprende-se a escrever } \\
\text { escrevendo" }\end{array}$ & 2 & - & - & 2 \\
\hline 7 & $\begin{array}{l}\text { "Texto: um problema para o } \\
\text { exercício da capatazia" }\end{array}$ & 2 & - & - & 2 \\
\hline 8 & $\begin{array}{c}\text { "Culturas orais em sociedades } \\
\text { letradas" }\end{array}$ & 2 & - & - & 2 \\
\hline 9 & $\begin{array}{l}\text { "Pesquisa em linguagem na } \\
\text { contemporaneidade" }\end{array}$ & 2 & - & - & 2 \\
\hline 10 & $\begin{array}{l}\text { "Prática de produção de textos na } \\
\text { escola" }\end{array}$ & 1 & - & 1 & 2 \\
\hline 11 & $\begin{array}{l}\text { "A prática escolar } \\
\text { sob escrutínio" }\end{array}$ & 1 & - & 1 & 2 \\
\hline 12 & $\begin{array}{l}\text { "Paulo Freire: } \\
\text { narrador e pensador" }\end{array}$ & 1 & 1 & - & 2 \\
\hline 13 & $\begin{array}{l}\text { "A linguagem nos processos sociais } \\
\text { de constituição da subjetividade" }\end{array}$ & 1 & 1 & - & 2 \\
\hline
\end{tabular}

124 Saliento que houve uma alteração no texto "A linguagem nos processos sociais de constituição da subjetividade". No artigo em periódico, registra-se subtítulo "A linguagem nos processos sociais de constituição da subjetividade: questões para pensar a cidadania: a língua e o imaginário", o qual não consta na publicação sob a forma de capítulo de livro. 
Fonte: Bibliografia de e sobre J. W. Geraldi: um instrumento de pesquisa (PAULA, 2009a) (Apêndice A)

A publicação de textos sob o mesmo título em diferentes veículos indica, ao mesmo tempo, a veiculação do pensamento de Geraldi e a sua abrangência em vários estados brasileiros, em se tratando da divulgação pelos periódicos em universidades e os vários convites para publicação, por parte de autores de livros e de sua participação em vários eventos no Brasil e no exterior.

Um outro aspecto também indicativo dessa veiculação se refere ao maior número de textos de Geraldi, publicados como artigos em periódicos, resultando em 64 artigos publicados em 45 diferentes periódicos de vários estados do Brasil e também de Portugal, todos abrangendo três diferentes áreas: Letras, Linguística e Educação.

Esses periódicos são divulgados nas grandes universidades brasileiras e também nas universidades de Portugal, tendo por interlocutores alunos de graduação e de pós-graduação. Inicialmente os artigos de Geraldi eram divulgados apenas em periódicos brasileiros. No entanto, a partir de 2002, iniciou-se uma divulgação de seu pensamento também junto a outros países, dada a sua atuação em Portugal e na Alemanha, como anteriormente mencionado.

O primeiro artigo de Geraldi em periódico estrangeiro se trata de "Culturas orais e língua escrita: três retratos três por quatro" (2002), publicado em Palavras (Lisboa/Portugal), periódico vinculado à Associação de Professores de Português (APP) de Lisboa. Também nesse periódico, Geraldi teve mais dois artigos publicados: "Depois do show, como encontrar encantamento?" (2004) e "Pesquisa em linguagem na contemporaneidade" (2007).

Em outros dois periódicos de Portugal, Geraldi teve dois artigos publicados: "A linguagem em Paulo Freire" (2005), em Educação, sociedade \& culturas, vinculado à Universidade do Porto (Porto/Portugal), e "Percursos da consolidação da didáctica de línguas em Portugal: análise dos estudos realizados no âmbito das unidades de investigação científica, subsidiadas pela Fundação para a Ciência e Tecnologia, na área das ciências da educação" (2004), publicado em Investigar em Educação, vinculado à Revista da Sociedade Portuguesa de Ciências da Educação (Braga/Portugal).

Com exceção desses cinco artigos publicados em periódicos portugueses, 59 foram publicados em 45 diferentes periódicos brasileiros, a maioria deles vinculados a instituições do estado de São Paulo, resultando em um total de 27 artigos em 15 periódicos. Por ordem 
alfabética, são eles: $\mathrm{ANDE}^{125}$, vinculado à Associação Nacional de Educação (São Paulo); Cadernos CEDES ${ }^{126}$, vinculado ao CEDES (Campinas); Cadernos de estudos lingüísticos, vinculado ao IEL/Departamento de Linguística (Campinas); D.E.L.T.A ${ }^{127}$, vinculado à PUC (São Paulo); Discutindo Língua Portuguesa, vinculado à editora Escala Educacional (São Paulo); Educação \& sociedade, vinculado ao CEDES, da UNICAMP (Campinas); Idéias, vinculado à $\mathrm{FDE}^{128}$ (São Paulo); Leitura: teoria \& prática, vinculado à ALB (Campinas); Letras, vinculado à PUC (Campinas); Linha d'água, vinculado à APLL, da FFLCH/USP (São Paulo); Nova escola, vinculado à Fundação Victor Civita (São Paulo); Quaestio, vinculado à Universidade de Sorocaba (UNISO) (Sorocaba); Revista de educação, vinculada ao Sindicato dos Professores do Ensino Oficial do Estado de São Paulo (APEOESP) (São Paulo); SENAI ${ }^{129}$, vinculado ao SENAI (São Paulo); Trabalhos em lingüistica aplicada, vinculado ao Departamento de Linguística Aplicada, do IEL/UNICAMP (Campinas).

Em três periódicos paulistas, Geraldi teve o maior número de artigos publicados, quatro em cada: Cadernos de estudos lingüisticos, Educação \& sociedade e Trabalhos em lingüística aplicada. Esses três periódicos estão vinculados à UNICAMP (Campinas), universidade a que Geraldi esteve vinculado desde a Especialização em Linguística, como anteriormente mencionado. Os três periódicos estão respectivamente relacionados à publicação de assuntos sobre educação e sobre práticas em sala de aula.

O segundo estado em que Geraldi mais teve artigos publicados em periódicos, resultando em um total de 11 artigos em seis periódicos, é seu estado de origem, Rio Grande do Sul. São esses os periódicos: A paixão de aprender, vinculado à Secretaria Municipal de Educação (Porto Alegre); Boletim da $A P L L^{130}-R S$, vinculado à UFGRS (Porto Alegre); Cadernos da FIDENE, vinculado à FIDENE (Ijuí); Contexto \& educação, vinculado à Universidade de Ijuí (Ijuí); Letras de hoje, vinculado à PUC (Porto Alegre); Organon, vinculado à UFRGS (Porto Alegre); e Signo, vinculado ao Centro de Estudos e Pesquisas Linguísticas e Literárias (CEPELL), da Faculdade de Filosofia, Ciências e Letras (Santa Cruz do Sul). Em Signo, foram publicados cinco artigos de Geraldi, seu maior número de artigos em periódico do estado do Rio Grande do Sul.

No estado do Rio de Janeiro, Geraldi teve quatro artigos publicados em quatro diferentes periódicos: BOLETIM DA ABRALIN, vinculado à Associação Brasileira de

\footnotetext{
${ }^{125}$ Associação Nacional de Educação (ANDE).

${ }^{126}$ Centro de Estudos Educação \& Sociedade (CEDES).

${ }^{127}$ Documentação de Estudos em Linguística Teórica e Aplicada (D.E.L.T.A).

${ }^{128}$ Fundação para o Desenvolvimento da Educação (FDE).

${ }^{129}$ Serviço Nacional de Aprendizagem Industrial (SENAI).

${ }^{130}$ Associação de Professores de Língua e Literatura (APLL).
} 
Linguística (Rio de Janeiro); Boletim informativo FNLIJ, vinculado à FNLIJ (Rio de Janeiro); Ciclos em revista, vinculado à Wak Editora (Rio de Janeiro); e Escola e vídeo, vinculado à Fundação Roberto Marinho (Rio de Janeiro).

Em Brasília/DF, três artigos foram publicados em três diferentes periódicos: Em aberto, vinculado ao INEP ${ }^{131}$; INES ${ }^{132}$, vinculado ao INES; e Revista de educação $A E C^{133}$, vinculado à $\mathrm{AEC}$ (Brasília/DF).

No estado de Minas Gerais, três artigos foram publicados em dois periódicos: um artigo em Dois pontos: teoria e prática em educação, vinculado ao Grupo Pitágoras (Belo Horizonte); e dois, em Série Estudos, vinculado ao Instituto de Letras das Faculdades Integradas Santo Tomás de Aquino (Uberaba).

No estado do Espírito Santo, Geraldi teve dois artigos publicados em dois diferentes periódicos: em Cadernos Camilliani, vinculado ao Centro Universitário São Camilo (Cachoeiro do Itapemirim); e em Cadernos de pesquisa em educação, vinculado à Universidade Federal do Espírito Santo (UFES) (Espírito Santo).

No estado do Mato Grosso, Geraldi teve dois artigos publicados em dois diferentes periódicos: em Polifonia, vinculado à Universidade Federal de Mato Grosso (UFMT) (Cuiabá/MT); e em Revista Ecos, vinculada à Fundação de Amparo à Pesquisa do Estado do Mato Grosso (FAPEMAT) (Cáceres/MT).

Em seis estados brasileiros, Geraldi teve seis artigos publicados em diferentes periódicos: em Educar em Revista, vinculado à UFPR (Curitiba), do estado do Paraná; em Leitura: estudos lingüísticos e literários, vinculado à Universidade Federal de Alagoas (Maceió), do estado de Alagoas; em Práxis, vinculado à Universidade Federal de Rondônia (UNIR) (Cacoal), do estado de Rondônia; em Linguagem em discurso, vinculado à Universidade do Sul de Santa Catarina (UNISUL) (Tubarão), do estado de Santa Catarina; em Revista Freinet, vinculada à Associação Brasileira para Divulgação, Estudos e Pesquisas da Pedagogia Freinet (ABDEPP), do estado do Rio Grande do Norte; e em Signótica, vinculada à Universidade Federal de Goiás (UFG), do estado de Goiás.

Os periódicos, as instituições a que estão vinculados, os locais de publicação, assim como o número de artigos de Geraldi publicados em cada periódico constam do Quadro 5, abaixo.

\footnotetext{
${ }^{131}$ Instituto Nacional de Estudos e Pesquisas Educacionais (INEP).

${ }^{132}$ Instituto Nacional de Educação de Surdos (INES).

${ }^{133}$ Associação de Educação Católica do Brasil (AEC).
} 


\section{Quadro 5 - Periódicos, instituições, locais de publicação e número de artigos de Geraldi publicados, por ordem alfabética de periódicos}

\begin{tabular}{|c|c|c|c|c|}
\hline $\begin{array}{l}\text { NÚMERO } \\
\text { DE } \\
\text { PERIÓDI- } \\
\text { COS } \\
\end{array}$ & PERIÓDICOS & INSTITUIÇÕES & $\begin{array}{c}\text { LOCAIS DE } \\
\text { PUBLICA- } \\
\text { ÇÃO }\end{array}$ & $\begin{array}{c}\text { NÚMERO DE } \\
\text { ARTIGOS POR } \\
\text { PERIÓDICO }\end{array}$ \\
\hline 1 & A paixão de aprender & SME & $\begin{array}{c}\text { Porto } \\
\text { Alegre/RS }\end{array}$ & 1 \\
\hline 2 & $A N D E$ & $\begin{array}{l}\text { Associação Nacional de } \\
\text { Educação }\end{array}$ & São Paulo/SP & 1 \\
\hline 3 & BOLETIM DA ABRALIN & $\begin{array}{c}\text { Associação Brasileira de } \\
\text { Linguística }\end{array}$ & $\begin{array}{c}\text { Rio de } \\
\text { Janeiro/RJ }\end{array}$ & 1 \\
\hline 4 & Boletim da APLL-RS & UFGRS & $\begin{array}{c}\text { Porto } \\
\text { Alegre/RS }\end{array}$ & 1 \\
\hline 5 & Boletim informativo FNLIJ & FNLIJ & Rio de & 1 \\
\hline 6 & Cadernos Camilliani & $\begin{array}{l}\text { Centro Universitário São } \\
\text { Camilo }\end{array}$ & $\begin{array}{l}\text { Cachoeiro do } \\
\text { Itapemirim/ES }\end{array}$ & 1 \\
\hline 7 & Cadernos CEDES & CEDES & Campinas/SP & 1 \\
\hline 8 & Cadernos da FIDENE & FIDENE & Ijuí/RS & 2 \\
\hline 9 & $\begin{array}{l}\text { Cadernos de estudos } \\
\text { lingüísticos }\end{array}$ & $\begin{array}{l}\text { IEL/Departamento de } \\
\text { Linguística }\end{array}$ & Campinas/SP & 4 \\
\hline 10 & $\begin{array}{c}\text { Cadernos de pesquisa em } \\
\text { educação }\end{array}$ & UFES & Vitória/ES & 1 \\
\hline 11 & Ciclos em revista & Wak Editora & $\begin{array}{c}\text { Rio de } \\
\text { Janeiro/RJ }\end{array}$ & 1 \\
\hline 12 & Contexto \& educação & UNIJUÍ & Ijuí/RS & 1 \\
\hline 13 & D.E.L.T.A & $\mathrm{PUC} / \mathrm{SP}$ & São Paulo/SP & 1 \\
\hline 14 & $\begin{array}{l}\text { Discutindo Língua } \\
\text { Portuguesa }\end{array}$ & Escala Educacional & São Paulo/SP & 1 \\
\hline 15 & $\begin{array}{l}\text { Dois pontos: teoria e } \\
\text { prática em educação }\end{array}$ & Grupo Pitágoras & $\begin{array}{c}\text { Belo } \\
\text { Horizonte/MG }\end{array}$ & 1 \\
\hline 16 & Educação \& sociedade & CEDES & Campinas/SP & 3 \\
\hline 17 & $\begin{array}{c}\text { Educação, sociedade \& } \\
\text { culturas }\end{array}$ & Universidade do Porto & Porto/Portugal & 1 \\
\hline 18 & Educar em Revista & UFPR & Curitiba/PR & 1 \\
\hline 19 & Em aberto & INEP & Brasília/DF & 1 \\
\hline 20 & Escola e vídeo & Fundação Roberto Marinho & Rio de & 1 \\
\hline 21 & Idéias & FDE & São Paulo/SP & 1 \\
\hline 22 & Investigar em Educação & $\begin{array}{l}\text { Sociedade Portuguesa de } \\
\text { Ciências da Educacão }\end{array}$ & $\begin{array}{c}\text { Braga/Portuga } \\
1\end{array}$ & 1 \\
\hline 23 & $I N E S$ & INES/MEC & Brasília/DF & 1 \\
\hline 24 & $\begin{array}{c}\text { Leitura: estudos } \\
\text { lingüísticos e literários }\end{array}$ & $\begin{array}{c}\text { UFAL/Departamento de } \\
\text { Letras Clássicas e Vernáculas }\end{array}$ & Maceió/AL & 1 \\
\hline 25 & Leitura: teoria \& prática & ALB & Campinas/SP & 3 \\
\hline 26 & Letras & PUC/Campinas & Campinas/SP & 1 \\
\hline 27 & Letras de hoje & PUC/RS & Porto & 1 \\
\hline 28 & Linguagem em discurso & UNISUL/SC & Tubarão/SC & 1 \\
\hline 29 & Linha d'água & APLL/FFLCH/USP & São Paulo/SP & 2 \\
\hline 30 & Nova escola & Fundação Victor Civita & São Paulo & 1 \\
\hline 31 & Organon & UFRGS & Porto & 1 \\
\hline 32 & Palavras & APP & $\begin{array}{l}\text { Lisboa/Portu } \\
\text { gal }\end{array}$ & 3 \\
\hline 33 & Polifonia & UFMT & Cuiabá/MT & 1 \\
\hline
\end{tabular}




\begin{tabular}{|c|c|c|c|c|}
\hline 34 & Práxis & UNIR & Cacoal/RO & 1 \\
\hline 35 & Quaestio & UNISO & Sorocaba/SP & 2 \\
\hline 36 & Revista de educação & APEOESP & São Paulo/SP & 1 \\
\hline 37 & Revista Ecos & FAPEMAT & Cáceres/MT & 1 \\
\hline 38 & Revista Freinet & ABDEPP & Natal/RN & 1 \\
\hline 39 & Revista de educação $A E C$ & $\mathrm{AEC}$ & Brasília/DF & 1 \\
\hline 41 & SENAI & SENAI & São Paulo/SP & 1 \\
\hline 42 & Série Estudos & $\begin{array}{c}\text { Instituto de Letras/Faculdades } \\
\text { Integradas Santo Tomás de } \\
\text { Aquino }\end{array}$ & Uberaba/MG & 2 \\
\hline 43 & Signo & $\begin{array}{c}\text { CEPELL/Faculdade de } \\
\text { Filosofia, Ciências e Letras }\end{array}$ & $\begin{array}{l}\text { Santa Cruz do } \\
\text { Sul/RS }\end{array}$ & 5 \\
\hline 44 & Signótica & UFG & Goiânia/GO & 1 \\
\hline 45 & $\begin{array}{c}\text { Trabalhos em lingüistica } \\
\text { aplicada }\end{array}$ & $\begin{array}{l}\text { IEL/Departamento de } \\
\text { Linguística Aplicada }\end{array}$ & Campinas/SP & 4 \\
\hline \multicolumn{5}{|c|}{$\begin{array}{ll}\text { TOTAL } & 64\end{array}$} \\
\hline
\end{tabular}

Fonte: Bibliografia de e sobre J. W. Geraldi: um instrumento de pesquisa (PAULA, 2009a) (Apêndice A)

Considerando as condições de circulação desses periódicos, em várias universidades brasileiras e também portuguesas, é possível inferir que o interlocutor pretendido por Geraldi em seus textos sempre foi o professor em formação (alunos de graduação e de pósgraduação), com quem estabeleceu e ainda estabelece embates teóricos.

Com relação às editoras que publicaram seus livros, o autor também teve livros publicados por editoras brasileiras e estrangeiras, o que indica a circulação e expansão de seu pensamento para outros países.

No quadro 6, apresento a relação de livros de Geraldi publicados, organizados por editoras e localidade. 


\section{Quadro 6 - Editoras que publicaram livros de Geraldi, por número} de ocorrência e coleções que integram

\begin{tabular}{|c|c|c|c|c|}
\hline EDITORAS & $\begin{array}{l}\text { LOCALI- } \\
\text { DADE }\end{array}$ & LIVROS & COLEÇÕES & $\begin{array}{l}\text { OCORRÊN- } \\
\text { CIAS }\end{array}$ \\
\hline $\begin{array}{l}\text { ALB/Mercado } \\
\text { de Letras }\end{array}$ & Campinas/SP & $\begin{array}{l}\text { Linguagem e ensino: exercícios } \\
\text { de militância e divulgação (1996) }\end{array}$ & "Leituras no Brasil" & 2 \\
\hline $\begin{array}{l}\text { Mercado de } \\
\text { Letras }\end{array}$ & & $\begin{array}{c}\text { Transgressões convergentes: } \\
\text { Vigotski, Bakhtin, Bateson } \\
\text { (2004) }\end{array}$ & & \\
\hline Assoeste & Cascavel/PR & $\begin{array}{c}\text { O texto na sala de aula: leitura \& } \\
\text { produção (1984) }\end{array}$ & - & 1 \\
\hline Ática & São Paulo/SP & $\begin{array}{c}\text { Semântica }(1985) \\
\text { O texto na sala de aula }(1997) \\
\text { O texto na sala de aula }(2005)\end{array}$ & $\begin{array}{l}\text { "Série Princípios" } \\
\text { "Coleção Na Sala de } \\
\text { Aula" }\end{array}$ & 3 \\
\hline Atual & São Paulo/SP & $\begin{array}{c}\text { O ensino de língua portuguesa } \\
\text { no } 1^{\circ} . \text { grau: projeto magistério } \\
(1986)\end{array}$ & "Projeto Magistério" & 1 \\
\hline Cortez & São Paulo/SP & $\begin{array}{c}\text { Aprender e ensinar com textos de } \\
\text { alunos (1997) }\end{array}$ & $\begin{array}{c}\text { "Aprender e ensinar com } \\
\text { textos" }\end{array}$ & 1 \\
\hline $\begin{array}{c}\text { Edição Instituto } \\
\text { Paulo Freire de } \\
\text { Portugal/Centro } \\
\text { de Recursos } \\
\text { Paulo Freire da } \\
\text { Faculdade de } \\
\text { Psicologia e } \\
\text { Ciências da } \\
\text { Educação } \\
\text { (FPCE) } \\
\end{array}$ & Porto-Portugal & $\begin{array}{c}\text { Diálogos através de Paulo } \\
\text { Freire (2004) }\end{array}$ & - & 1 \\
\hline IEL/UNICAMP & Campinas/SP & $\begin{array}{c}\text { Sobre a estruturação do discurso } \\
\text { (1981) }\end{array}$ & - & 1 \\
\hline $\begin{array}{c}\text { Livraria do } \\
\text { Arquiteto }\end{array}$ & $\begin{array}{c}\text { Porto } \\
\text { Alegre/RS }\end{array}$ & $\begin{array}{l}\text { Janelas para o mundo: diálogo } \\
\text { com outras vozes (2006) }\end{array}$ & - & 1 \\
\hline Martins Fontes & São Paulo/SP & Portos de passagem (1991) & "Texto e linguagem" & 1 \\
\hline $\begin{array}{l}\text { Universidad de } \\
\text { Talca }\end{array}$ & Talca/Chile & $\begin{array}{l}\text { Paulo Freire: una reflexión sobre } \\
\text { la educación, administración y } \\
\text { política en el município de São } \\
\text { Paulo, Brasil (1994) }\end{array}$ & - & 1 \\
\hline $\begin{array}{c}\text { Universidade de } \\
\text { Aveiro, Campus } \\
\text { de Santiago } \\
\end{array}$ & $\begin{array}{l}\text { Aveiro/Portu- } \\
\text { gal }\end{array}$ & $\begin{array}{c}\text { A aula como acontecimento } \\
\text { (2004) }\end{array}$ & - & 1 \\
\hline Vozes & $\begin{array}{c}\text { Rio de } \\
\text { Janeiro/RJ }\end{array}$ & $\begin{array}{l}\text { Paulo Freire: trabalho, } \\
\text { comentário, reflexão (1990) }\end{array}$ & - & 1 \\
\hline \multicolumn{4}{|c|}{ TOTAL DE LIVROS PUBLICADOS } & 15 \\
\hline
\end{tabular}

Fonte: Bibliografia de e sobre J. W. Geraldi: um instrumento de pesquisa (PAULA, 2009a) (Apêndice A) 
Analisando o quadro n. 7, é possível considerar que os livros de Geraldi foram publicados por diferentes editoras, de representatividade tanto no mercado editorial brasileiro quanto no mercado editorial de dois outros países: Chile e Portugal. A única exceção se refere ao livro O texto na sala de aula: leitura \& produção (1984), publicado pela Assoeste/PR, que, por ser uma editora regional, não conseguiu atender à demanda da coletânea, a qual, por esse motivo, a partir de 1997 passou a ser editada pela Ática.

Comparativamente, a Ática é a editora brasileira de maior publicação de livros de Geraldi, tendo sido publicados por ela três de seus livros. Essa editora assumiu, no final da década de 1990, a publicação da coletânea $O$ texto na sala de aula (1997, 2005), e anteriormente já havia publicado o livro Semântica (1985).

Em segundo lugar, em número de publicação de livros, destaca-se a editora Mercado de Letras, que, em parceria com a editora da ALB, primeiramente publicou o livro: Linguagem e ensino: exercícios de militância e divulgação (1996) e, mais recentemente, Transgressões convergentes: Vigotski, Bakhtin, Bateson (2004).

Pelas demais editoras, houve a publicação de apenas um livro: pela Assoeste, como anteriormente mencionei, a publicação de $O$ texto na sala de aula: leitura \& produção (1984); pela Atual, a publicação de $O$ ensino de língua portuguesa no $1^{\circ}$. grau: projeto magistério (1986); pela Cortez, a publicação de Aprender e ensinar com textos de alunos (1997); pela Edição Instituto Paulo Freire de Portugal/Centro de Recursos Paulo Freire da FPCE, a publicação de Diálogos através de Paulo Freire (2004); pelo IEL/UNICAMP, a publicação de Sobre a estruturação do discurso (1981); pela Livraria do Arquiteto, a publicação de Janelas para o mundo: diálogo com outras vozes (2006); pela Martins Fontes, a publicação de Portos de passagem (1991); pela Universidad de Talca, a publicação de Paulo Freire: una reflexión sobre la educación, administración y política en el município de São Paulo, Brasil (1994); pela Universidade de Aveiro/Campus de Santiago, a publicação de A aula como acontecimento (2004); e pela editora Vozes, a publicação de Paulo Freire: trabalho, comentário, reflexão (1990).

É interessante observar que, especialmente dentre os livros publicados pelas editoras brasileiras, seis deles integram coleções. Dentre os livros publicados pela ALB/Mercado de Letras, Linguagem e ensino: exercícios de militância e divulgação (1996) integra a coleção "Leituras no Brasil"; pela editora Ática, o livro Semântica (1985) integra a "Série Princípios" e O texto na sala de aula (1997) integra a "Coleção Na Sala de Aula"; pela Atual, O ensino de língua portuguesa no $1^{\circ}$. grau integra a coleção "Projeto Magistério"; pela Cortez, Aprender e ensinar com textos de alunos (1997) integra a coleção “Aprender e ensinar com 
textos"; e pela Martins Fontes, Portos de passagem (1991) integra a coleção "Texto e linguagem".

O fato de seis livros de Geraldi integrarem coleções das editoras indica não somente um momento de intensa publicação no mercado editorial, já que o objetivo dos cursos na época era formar professores para atender a todos os alunos brasileiros que estavam nas escolas, e, por esse motivo, as editoras passavam por um momento de efervescência, mas também indicam o conteúdo que era pensado na época referente às publicações. Nesse sentido, o pensamento de Geraldi apresenta aspectos em comum com o pensamento de outros professores do IEL/UNICAMP e de outras universidades brasileiras, que refletiam sobre as mesmas questões naquela época, as quais também foram publicadas por diversas editoras.

Com relação aos 31 capítulos de livro de Geraldi, eles foram publicados em 30 livros, organizados por 28 diferentes autores, como pode ser observado no quadro abaixo. 
Quadro 7 - Organizadores e livros em que foram publicados capítulos de livros de Geraldi, por ordem alfabética de organizador

\begin{tabular}{|c|c|c|c|c|}
\hline $\begin{array}{l}\text { OCOR } \\
- \\
\text { RÊN- } \\
\text { CIA }\end{array}$ & $\begin{array}{l}\text { ORGANIZADO- } \\
\text { R(ES) DOS LIVROS }\end{array}$ & $\begin{array}{l}\text { LIVROS EM QUE FOI } \\
\text { PUBLICADO }\end{array}$ & $\begin{array}{c}\text { CAPÍTULOS DE } \\
\text { AUTORIA/CO-AUTORIA DE } \\
\text { GERALDI }\end{array}$ & $\begin{array}{l}\text { NÚMER } \\
\text { O DE } \\
\text { CAPÍ- } \\
\text { TULOS }\end{array}$ \\
\hline 1 & Adriano Nogueira & $\begin{array}{c}\text { Contribuições da } \\
\text { interdisciplinaridade para } \\
\text { a ciência, para a educação } \\
\text { e para o trabalho sindical } \\
\\
\text { Ciência para quem? } \\
\text { Formação científica para } \\
\text { quê?: a formação do } \\
\text { professor conforme } \\
\text { desafios regionais }\end{array}$ & $\begin{array}{l}\text { Trabalho com a linguagem e } \\
\text { história da educação na rede de } \\
\text { ensino (1994) } \\
\text { Uma reflexão interdisciplinar a } \\
\text { partir da análise lingüística de um } \\
\text { texto produzido por um aluno } \\
\text { (1994) } \\
\text { Linguagem, cultura e educação: a } \\
\text { formação científica de } \\
\text { profissionais educadores }(2000)\end{array}$ & 3 \\
\hline 2 & $\begin{array}{c}\text { Anna Maria Marques } \\
\text { Cintra }\end{array}$ & $\begin{array}{c}\text { Ensino de língua } \\
\text { portuguesa: reflexão e } \\
\text { ação }\end{array}$ & $\begin{array}{c}\text { Correlações entre as situações } \\
\text { políticas e as preocupações com a } \\
\text { língua portuguesa (2008) }\end{array}$ & 1 \\
\hline 3 & $\begin{array}{l}\text { Beatriz Judith Lima } \\
\text { Scoz; Leda M. C. } \\
\text { Barone; Maria C. M } \\
\text { Campos; Mônica } \\
\text { Mendes }\end{array}$ & $\begin{array}{c}\text { Psicopedagogia: } \\
\text { contextualização, formação } \\
\text { e atuação profissional }\end{array}$ & Linguagem e ação (1991) & 1 \\
\hline 4 & $\begin{array}{c}\text { Cláudio Almir } \\
\text { Dalbosco; Gerson } \\
\text { Luís Trombetta; } \\
\text { Solange Maria Longhi }\end{array}$ & $\begin{array}{c}\text { Sobre filosofia e } \\
\text { educação: subjetividade - } \\
\text { intersubjetividade na } \\
\text { fundamentação da práxis } \\
\text { pedagógica }\end{array}$ & $\begin{array}{c}\text { Depois do show, como encontrar } \\
\text { encantamento? (2004) }\end{array}$ & 1 \\
\hline 5 & $\begin{array}{c}\text { Comissão de } \\
\text { Educação e Cultura da } \\
\text { Câmara dos } \\
\text { Deputados }\end{array}$ & $\begin{array}{c}\text { Perspectivas e propostas } \\
\text { na formação para o } \\
\text { mundo do trabalho }\end{array}$ & $\begin{array}{c}\text { A formação de jovens diante das } \\
\text { exigências do mercado de } \\
\text { trabalho }(2008)\end{array}$ & 1 \\
\hline 6 & Denilda Moura & $\begin{array}{c}\text { Os desafios da língua: } \\
\text { pesquisas em língua falada } \\
\text { e escrita } \\
\end{array}$ & $\begin{array}{c}\text { A infatigável tarefa de frear a } \\
\text { língua (2008) }\end{array}$ & 1 \\
\hline 7 & Edwiges Zaccur & A magia da linguagem & $\begin{array}{c}\text { Da sala de aula à construção } \\
\text { externa da aula (1999) }\end{array}$ & 1 \\
\hline 8 & $\begin{array}{l}\text { Eleonora Albano; } \\
\text { Maria Irma Coudre; } \\
\text { Sírio Possenti; Tânia } \\
\text { Alkmin }\end{array}$ & Saudades da língua & $\begin{array}{c}\text { Convívio paradoxal com o ensino } \\
\text { da leitura e escrita (2003) }\end{array}$ & 1 \\
\hline 9 & $\begin{array}{c}\text { Eni Pulcinelli Orlandi; } \\
\text { Sírio Possenti ; João } \\
\text { Wanderley Geraldi ; } \\
\text { Eduardo J. Guimarães } \\
\text { e Jesus Antonio } \\
\text { Durigan } \\
\end{array}$ & $\begin{array}{c}\text { Sobre a estruturação do } \\
\text { discurso }\end{array}$ & $\begin{array}{c}\text { Tópico-comentário e orientação } \\
\text { argumentativa (1981) }\end{array}$ & 1 \\
\hline
\end{tabular}




\begin{tabular}{|c|c|c|c|c|}
\hline 10 & Flávio Aguiar & $\begin{array}{c}\text { Antonio Candido: } \\
\text { pensamento e militância }\end{array}$ & $\begin{array}{l}\text { Professor, militante e pensador } \\
\text { (1999) }\end{array}$ & 1 \\
\hline 11 & $\begin{array}{l}\text { Gláucia Muniz } \\
\text { Proença Lara }\end{array}$ & $\begin{array}{c}\text { Língua(gem), texto, } \\
\text { discurso: entre a reflexão e } \\
\text { a prática }\end{array}$ & $\begin{array}{l}\text { A presença do texto na sala de } \\
\text { aula (2006) }\end{array}$ & 1 \\
\hline 12 & $\begin{array}{l}\text { Inês F. S. Bragança; } \\
\text { Mairce S. Araújo; } \\
\text { Marcia S. Alvarenga; } \\
\text { Lúcia V. Maurício }\end{array}$ & $\begin{array}{c}\text { Vozes da educação: } \\
\text { memórias, histórias e } \\
\text { formação de professores }\end{array}$ & $\begin{array}{l}\text { Ler e escrever: uma mera } \\
\text { exigência escolar? (2008) }\end{array}$ & 1 \\
\hline 13 & $\begin{array}{c}\text { Juracilda Veiga; } \\
\text { Wilmar da Rocha } \\
\text { D’Angelis }\end{array}$ & $\begin{array}{l}\text { Escola indígena, } \\
\text { identidade étnica e } \\
\text { autonomia }\end{array}$ & $\begin{array}{l}\text { Conteúdos de ensino e conteúdos } \\
\text { escolares: em defesa de uma } \\
\text { escola de sistematização de } \\
\text { conhecimentos produzidos pelas } \\
\text { práticas sociais (2003) }\end{array}$ & 1 \\
\hline 14 & $\begin{array}{l}\text { Leonira M. G. } \\
\text { Komosinski; R. } \\
\text { Kohlrausch }\end{array}$ & $\begin{array}{l}\text { A linguagem descobrindo } \\
\text { mundos: ensino de línguas } \\
\text { portuguesa, espanhola e } \\
\text { literatura }\end{array}$ & $\begin{array}{l}\text { Notas sobre a exclusão da língua } \\
\text { geral e a introdução da língua } \\
\text { portuguesa }(2001)\end{array}$ & 1 \\
\hline 15 & $\begin{array}{c}\text { Lígia Negri; Maria J. } \\
\text { Foltran; Roberta P. } \\
\text { Oliveira } \\
\end{array}$ & $\begin{array}{c}\text { Sentido e significação: em } \\
\text { torno da obra de Rodolfo } \\
\text { Ilari } \\
\end{array}$ & $\begin{array}{l}\text { Alteridades: espaços e tempos de } \\
\text { instabilidades (2004) }\end{array}$ & 1 \\
\hline 16 & $\begin{array}{l}\text { Luiza Cortezão; Rosa } \\
\text { Nunes; Abreu Freire; } \\
\text { Rui Trindade; João E. } \\
\text { Romão } \\
\end{array}$ & $\begin{array}{c}\text { Diálogos através de Paulo } \\
\text { Freire }\end{array}$ & $\begin{array}{l}\text { Paulo Freire e Mikhail Bakhtin: o } \\
\text { encontro que não houve (2004) }\end{array}$ & 1 \\
\hline 17 & Marcelo Dascal & $\begin{array}{c}\text { Dialogue: an } \\
\text { interdisciplinary approach }\end{array}$ & $\begin{array}{c}\text { Argumentative operators and } \\
\text { dialogue }(1985)\end{array}$ & 1 \\
\hline 18 & $\begin{array}{l}\text { Maria Benites; Bernd } \\
\text { Fichtner }\end{array}$ & $\begin{array}{l}\text { Vom Ungang mi Differenz. } \\
\text { Globalizierung und } \\
\text { Regionalisierung in } \\
\text { interkulturellen Diskurs }\end{array}$ & $\begin{array}{l}\text { Alterität: räume und Zeiten der } \\
\text { Instabilität (2007) }\end{array}$ & 1 \\
\hline 19 & $\begin{array}{l}\text { Maria Benites; Bernd } \\
\text { Fichtner; Carlos } \\
\text { Maldonado; Lurdi } \\
\text { Haas; Corinta Geraldi; } \\
\text { João Wanderley } \\
\text { Geraldi; Clemens } \\
\text { Knobloch; Afira V. } \\
\text { Ripper; Joseane } \\
\text { Zaghetti; Maria } \\
\text { Florentina A. } \\
\text { Camerini; Sandra } \\
\text { Leibovici; Amauri } \\
\text { Lobo; Eunice Cesnik; } \\
\text { Alessandra Vidotti }\end{array}$ & $\begin{array}{l}\text { Janelas para o mundo: um } \\
\text { projeto de pesquisa e ação } \\
\text { Diálogos com outras vozes }\end{array}$ & $\begin{array}{c}\text { Tecnologias na escola, } \\
\text { tecnologias da escola (2006) }\end{array}$ & 1 \\
\hline 20 & Márcia Abreu & Leituras no Brasil & $\begin{array}{l}\text { A leitura em momento de crise } \\
\text { social (1995) }\end{array}$ & 1 \\
\hline 21 & $\begin{array}{l}\text { Maria da Graça F. da } \\
\text { Costa Val }\end{array}$ & $\begin{array}{c}\text { Reflexões sobre práticas } \\
\text { escolares de produção de } \\
\text { texto }\end{array}$ & $\begin{array}{c}\text { A linguagem nos processos } \\
\text { sociais de constituição da } \\
\text { subjetividade (2003) }\end{array}$ & 1 \\
\hline 22 & $\begin{array}{c}\text { Maria Flávia } \\
\text { Figueiredo; Marina } \\
\text { C.Mendonça; Vera } \\
\end{array}$ & $\begin{array}{l}\text { Sentidos em movimento: } \\
\text { identidade e argumentação }\end{array}$ & $\begin{array}{l}\text { Texto e discurso: questões } \\
\text { epistemológicas para a } \\
\text { Lingüística (2008) }\end{array}$ & 1 \\
\hline
\end{tabular}




\begin{tabular}{|c|c|c|c|c|}
\hline & Lúcia R. Abriata & & & \\
\hline 23 & Maria Helena Martins & Questões de linguagem & $\begin{array}{c}\text { O professor como leitor do texto } \\
\text { do aluno (1991) }\end{array}$ & 1 \\
\hline 24 & $\begin{array}{l}\text { Maria T. Freitas; } \\
\text { Solange J. Souza; } \\
\text { Sônia Kramer }\end{array}$ & $\begin{array}{l}\text { Ciências humanas e } \\
\text { pesquisa: leituras de } \\
\text { Mikhail Bakhtin }\end{array}$ & $\begin{array}{c}\text { A diferença identifica. A } \\
\text { desigualdade deforma. Percursos } \\
\text { bakhtinianos de construção ética } \\
\text { e estética (2003) }\end{array}$ & 1 \\
\hline 25 & $\begin{array}{l}\text { Norma Sandra de } \\
\text { Almeida Ferreira }\end{array}$ & Leitura: um cons/certo & $\begin{array}{l}\text { Paulo Freire e Mikhail Bakhtin: o } \\
\text { encontro que não houve (2003) }\end{array}$ & 1 \\
\hline 26 & $\begin{array}{l}\text { Regina L. Garcia; } \\
\text { Edwirges Zaccur }\end{array}$ & $\begin{array}{c}\text { Cotidiano e diferentes } \\
\text { saberes }\end{array}$ & $\begin{array}{c}\text { Alfabetizações cotidianas: as } \\
\text { letras da cidade e a cidade das } \\
\text { letras (2006) }\end{array}$ & 1 \\
\hline 27 & $\begin{array}{l}\text { Valdemir Miotello, } \\
\text { André Luiz Covre, } \\
\text { Fabrício César de } \\
\text { Oliveira, Diego } \\
\text { Aparecido Alves } \\
\text { Gomes Figueira, } \\
\text { Dionísio da Silva } \\
\text { Pimenta, Kátia } \\
\text { Vanessa Tarantini } \\
\text { Silvestre, Pedro } \\
\text { Guilherme Orzari } \\
\text { Bombonato, Rômulo } \\
\text { Augusto Orlandini, } \\
\text { Sandra Mara Azevedo, } \\
\text { Aline Maria Pacífico } \\
\text { Manfrim, Carlos } \\
\text { Alberto Turati, Ivo Di } \\
\text { Camargo Jr e Sidney } \\
\text { de Paulo }\end{array}$ & $\begin{array}{l}\text { Veredas bakhtinianas: de } \\
\text { objetos a sujeitos } \\
\text { O espelho de Bakhtin }\end{array}$ & $\begin{array}{c}\text { É possível investir nas } \\
\text { enunciações, sem as garantias dos } \\
\text { enunciados já firmados? (2006) } \\
\text { Leitura: uma oferta de } \\
\text { contrapalavras (2007) }\end{array}$ & 2 \\
\hline 28 & Valdir Heitor Barzotto & Estado de leitura & $\begin{array}{l}\text { Paulo Freire: narrador e pensador } \\
\text { (1999) }\end{array}$ & 1 \\
\hline \multicolumn{4}{|c|}{ TOTAL DE CAPÍTULOS DE LIVROS PUBLICADOS } & 31 \\
\hline \multicolumn{4}{|c|}{ TOTAL DE LIVROS EM QUE FORAM PUBLICADOS } & 30 \\
\hline \multicolumn{4}{|c|}{ TOTAL DE ORGANIZADOR(ES) } & 28 \\
\hline
\end{tabular}

Fonte: Bibliografia de e sobre $J$. W. Geraldi: um instrumento de pesquisa (PAULA, 2009a) (Apêndice A)

Três capítulos de livros foram publicados em dois livros organizados por Adriano Nogueira: "Trabalho com a linguagem e história da educação na rede de ensino" (1994) e "Uma reflexão interdisciplinar a partir da análise lingüística de um texto produzido por um aluno" (1994), publicados no livro Contribuições da interdisciplinaridade para a ciência, para a educação e para o trabalho sindical; e "Linguagem, cultura e educação: a formação científica de profissionais educadores" (2000), publicado no livro Ciência para quem? Formação científica para quê?: a formação do professor conforme desafios regionais.

Em dois livros sob a organização de Valdemir Miotello, André Luiz Covre, Fabrício César de Oliveira, Diego Aparecido Alves Gomes Figueira, Dionísio da Silva Pimenta, Kátia Vanessa Tarantini Silvestre, Pedro Guilherme Orzari Bombonato, Rômulo Augusto Orlandini, 
Sandra Mara Azevedo, Aline Maria Pacífico Manfrim, Carlos Alberto Turati, Ivo Di Camargo Jr e Sidney de Paulo ${ }^{134}$, foram publicados dois capítulos de livros: “É possível investir nas enunciações, sem as garantias dos enunciados já firmados?” (2006), no livro Veredas bakhtinianas: de objetos a sujeitos e "Leitura: uma oferta de contrapalavras" (2007), no livro O espelho de Bakhtin.

Os demais 26 capítulos, foram publicados em 26 diferentes livros, sob a organização de diferentes professor(es)/pesquisador(es) vinculados a universidades brasileiras e do exterior.

Esse conjunto de aspectos referentes às instituições responsáveis pelos periódicos em que foram publicados seus artigos, as editoras que publicaram seus livros e os diferentes organizadores dos livros em que foram publicados seus capítulos, dentre outros, é indicativo de que a publicação dos textos de Geraldi por diferentes editoras e instituições foi um dos quesitos responsáveis pelo conhecimento e reconhecimento de seu pensamento em território brasileiro, da década de 1980 até os dias atuais.

Com relação à temática de seus textos, sobressaem, em número, as tematizações sobre "o ensino de língua portuguesa", incluindo a fase inicial desse ensino, a alfabetização. No entanto, Geraldi também elaborou textos sobre: análises descritivas da linguagem; importantes pensadores para a educação brasileira ${ }^{135}$; educação em geral; questões científicas; e traduções de textos sobre teorias vigentes no Brasil.

Nesta tese, destaco especialmente os textos de Geraldi que abordam diretamente o ensino de língua portuguesa.

\subsubsection{Bibliografia de Geraldi sobre o ensino de língua portuguesa}

As reflexões de Geraldi sobre o ensino de língua portuguesa, no início da década de 1980, no momento em que ele começou a ministrar aulas dessa disciplina em sua cidade natal, São Luiz Gonzaga-RS, talvez tenham sido ocasionadoras de seu interesse em cursar a Licenciatura Curta em Letras; a Licenciatura Plena; a Especialização em Linguística; e os cursos de Mestrado e Doutorado no IEL/UNICAMP, como mencionado anteriormente. A

\footnotetext{
${ }^{134}$ Esses autores integram o Grupo de Estudos de Gêneros do Discurso (GEGE).

${ }^{135} \mathrm{Na}$ Bibliografia de Geraldi, estão inclusos textos sobre a atuação dos brasileiros Paulo Freire, Antonio Candido e Carlos Franchi, e sobre os estrangeiros Mikhail Bakhtin, Lev Vigotski e Gregory Bateson . O trabalho de Lev Vigotski e Gregory Bateson foram tematizados recentemente no livro Transgressões convergentes: Vigotski, Bakhtin, Bateson (2006), de Geraldi em co-autoria com Bernd Fichtner e Maria Benites, publicado pela editora Mercado de Letras.
} 
partir desses cursos, foi possível para ele conhecer diferentes concepções teóricas na área da Linguística, travando com elas muitos embates.

Em "Subsídios metodológicos para o ensino de língua portuguesa: $5^{\mathrm{a}}$. a $8^{\mathrm{a}}$. séries" (1981), encontram-se suas primeiras tematizações. Nesse periódico, dedicado a sua filha Joana, estando no momento da publicação com dois anos, Geraldi se compromete com o ensino de língua portuguesa, a partir de sua proposta, quando afirma que a filha "[...] não venha a sofrer o ensino que hoje fazemos nem aquele que aqui propomos, mas o melhor que criarmos" (1981, p. 1). Nesse periódico, foram publicados dois artigos: "Ensino da língua ou ensino da metalinguagem?" e "Unidades básicas do ensino de língua portuguesa", como anteriormente mencionei.

Esses dois artigos, outros dois de sua autoria e mais um em co-autoria com Maria Nilma Goes da Fonseca ${ }^{136}$, foram publicados na coletânea $O$ texto na sala de aula: leitura \& produção, em 1984, pela Assoeste, uma editora do oeste do estado do Paraná, visando à utilização desses textos no curso de formação de professores que Geraldi ministraria. A partir da publicação dessa coletânea, objeto de estudo de minha dissertação de mestrado (PAULA, 2004a), a atuação de Geraldi sobre o ensino de língua portuguesa foi intensa. A concepção teórica contida na coletânea teve continuidade especialmente em outros dois de seus livros, publicados posteriormente: Portos de passagem, resultante da tese de doutorado de Geraldi, e o livro Linguagem e ensino: exercícios de militância e divulgação, resultante de sua tese de livre-docência.

Além desses textos, em que considero estar publicada a matriz de seu pensamento, em outros textos seus foram contempladas questões singulares sobre a sua proposta para o ensino de língua portuguesa.

Quanto à produção de Geraldi publicada em livros, seis desses livros tematizam diretamente o ensino de língua portuguesa: $O$ texto na sala de aula: leitura \& produção (1984), O ensino de língua portuguesa no $1^{\circ}$. grau: projeto magistério (1986), Portos de passagem (1991), Linguagem e ensino: exercícios de militância e divulgação (1996), Aprender e ensinar com textos de alunos (1997) e A aula como acontecimento (2004). Desses livros, como mencionado anteriormente, três são tomados por objeto de análise nesta tese, pois considero estarem neles sintetizadas as ideias linguísticas constitutivas do pensamento de Geraldi sobre o ensino de língua portuguesa. Com relação aos outros três livros que abordam o ensino de língua portuguesa, dois deles foram elaborados em co-autoria: $O$ ensino de língua

${ }^{136}$ No momento de publicação da coletânea $O$ texto na sala de aula, Maria Nilma Goes da Fonseca era professora da Secretaria de Educação de Sergipe. Atualmente é professora da Universidade Federal de Sergipe (UFS). 
portuguesa no $1^{\circ}$. grau: projeto magistério (1986), com Lilian Lopes Martins da Silva, Sarita Moysés e Raquel Salek Fiad, e Aprender e ensinar com textos de alunos (1997) ${ }^{137}$, com Beatriz Citelli.

Dentre os textos de Geraldi publicados como capítulos de livros, 11 deles tematizam diretamente o ensino de língua portuguesa, a saber: "Linguagem e ação" (1991), "O professor como leitor do texto do aluno" (1991), "Trabalho com a linguagem e história da educação na rede de ensino" (1994), "A leitura em momento de crise social" (1995), "Da sala de aula à construção externa da aula" (1999), "A linguagem nos processos sociais de constituição da subjetividade" (2003), "Convívio paradoxal com o ensino da leitura e escrita" (2003), "A presença do texto na sala de aula" (2006), "É possível investir nas enunciações, sem as garantias dos enunciados já firmados?" (2006), "Leitura: uma oferta de contrapalavras" (2007) e "Ler e escrever: uma mera exigência escolar?” (2008).

Como já mencionado, os textos de Geraldi, em sua grande maioria, foram publicados como artigos em periódicos. Dentre eles, 14 tematizam diretamente o ensino de língua portuguesa: "Possíveis alternativas para o ensino da língua portuguesa" (1982), “Aprende-se a escrever escrevendo" (1985), "Prática de produção de textos na escola" (1986), “A leitura na sala de aula: as muitas faces de um leitor" (1988), "Educação e linguagem" (1989), "Texto: um problema para o exercício da capatazia" (1989), “A constituição do sujeito leitor” (1992), "Português: o aprendizado que vem da vida do próprio aluno" (1994), "Considerações sobre a utilização de um paradigma indiciário na análise de episódios de refacção textual” (1995) ${ }^{138}$, “A circulação escolar de textos produzidos por alunos" (1995), "Abordagem sóciointeracionista no ensino, leitura e escrita" (1996), "Palavras escritas, indícios de palavras ditas" (2000), “As aventuras do conhecer: da transmissão à interlocução" (2002) e "Há funções para o ensino escolar da gramática?” (2006).

Dentre os textos de Geraldi publicados como entrevistas, os que se referem diretamente ao ensino de língua portuguesa são: "Método se baseia na produção de textos" (1987), “Livro didático de língua portuguesa: a favor ou contra?” (1987), "Para repensar o ensino de português" (1989), “A sala de aula é uma oficina de dizer coisas” (1994), "Em

\footnotetext{
${ }^{137}$ Esse livro resultou da pesquisa intitulada "A circulação dos textos na escola", realizada por meio de trabalho interinstitucional, envolvendo docentes e alunos dos cursos de Letras, Comunicações e Educação da USP e do IEL/UNICAMP, e professores das escolas pública e particular, a partir de 1992.

${ }^{138}$ Sob o título "O caráter singular das operações de refacção nos textos representativos do início da aquisição da escrita" (1995), também em co-autoria de Geraldi com Maria Bernadete Abaurre, Maria Laura T. MayrinkSabinson e Raquel Salek Fiad, esse mesmo texto foi publicado em seminários do $24^{\circ}$. Grupo de estudos linguísticos (GEL).
} 
defesa do acesso ao mundo da escrita" (1996), "Recuperando as práticas de interlocução na sala de aula" (1998), "Entrevista sobre O texto na sala de aula" (2004), "Leitura e escrita na escola podem ser livres?" (2005), “Um bom professor ensina a perguntar" (2006), “Os pecados da Lingüística" (2008), "Entrevista ao Núcleo de Estudos e Pesquisas da Educação na Pequena Infância (NUPEIN)" (2008). Nesses textos, por diversas vezes, é tematizado o projeto desenvolvido por Geraldi e colaboradores, haja vista a importância de sua atuação para o ensino de língua portuguesa, assim como a expansão da temática bakhtiniana para todos os segmentos da área da educação.

Com relação aos textos de Geraldi, publicados em anais de eventos, e nos quais é abordado o ensino de língua portuguesa, destacam-se: "De como produzir milagres ou o professor pega um boizinho, rifa e compra livros" (1986), "Cinco questões sobre a questão dos métodos" (1988), "Ainda e sempre: leitura" (1992), "Políticas de inclusão em estruturas de exclusão" (1994), “A circulação de textos na escola: primeiros resultados" (1995), "Da produção do texto escolar" (1997) e "Sobre a constituição dos objetos de ensino em língua materna" (2000).

E, dentre os textos de Geraldi publicados como artigos em jornais de notícias, tematizam o ensino de língua portuguesa: “A destruidora didática dos livros" (1986) e "O livro didático de língua portuguesa: didatização e destruição da atividade lingüística” (1986).

Nos subtópicos a seguir, destacam-se aspectos referentes à produção de Geraldi sobre o ensino de língua portuguesa.

\subsubsection{A interlocução}

Interlocução, diálogo, enunciação, instabilidade, movimento e produção, tanto de sujeito quanto de linguagem, são ideias associadas e se constituem como palavras-chave na proposta de Geraldi para o ensino de língua portuguesa.

Apoiando-se na interlocução como principal processo de trabalho em sala de aula, Geraldi contribuiu “[...] não na categoria dialogismo ou dialogia, mas sim no diálogo que você pode encetar com as crianças ou com aqueles que cuidam dessas crianças" (GERALDI, 2008d, p. 9). Para ele, a aula se constrói no acontecimento da sala de aula, com os alunos, considerados sujeitos de seu conhecimento. Dessa forma, na sala de aula, segundo Geraldi, deve acontecer o diálogo entre os sujeitos que participam dessa interação e que provocam o "movimento linguístico" que caracteriza a prática de interacionismo, numa construção social, o que, para o autor, denomina-se sócio-interacionismo. 
Segundo Geraldi, Collares e Moysés (2002), "O acontecimento de sua enunciação é um novo enunciado resultante das formas de articulação próprias do já-dito com seus dizeres anteriormente internalizados, que se tornam a nova vestimenta do que o sujeito enuncia aqui e agora" (2002, p. 108).

Sob essa perspectiva, Geraldi critica o trabalho que ocorre em sala de aula, quando é pensado apenas em termos de transmissão, pois, para ele, o conhecimento é construído na interlocução com o sujeito, a partir da reflexão.

\subsubsection{O texto como objeto de ensino}

Abordando a interlocução e a interação do sujeito com o objeto, Geraldi propõe o trabalho com o texto, como unidade e objeto de ensino. Para ele, a prática anterior de ensino de língua portuguesa a sua proposta, que privilegiava o ensino da Gramática Tradicional, não permitia que o aluno se constituísse como sujeito e dono de seu pensar.

A partir dessas concepções de Geraldi, o texto passou a ser tomado como objeto de ensino, e o trabalho do professor, em sala de aula, começou a exigir deste um conhecimento pautado nas concepções de linguagem e de sujeito como conhecimentos sólidos, já que é necessária uma formação nessas teorias para aplicá-las na prática.

Sob essa perspectiva, Geraldi considera que o trabalho do professor deve estar pautado no ensino e na aprendizagem do texto do aluno, priorizando a reflexão sobre a linguagem. Esse modo de pensar o ensino advém da constatação de que os textos produzidos pelos alunos anteriormente indicavam que a prática de redação não lhes permitia a reflexão necessária para a produção de bons textos.

Geraldi critica o momento em que o professor deixou de "[...] articular os eixos epistemológico e das necessidades didático-pedagógicas [...]. A organização do conteúdo e a definição de modos de transmissão deste conteúdo passou a ser responsabilidade do autor do livro didático" (1989b, p. 157), e a essa prática, Geraldi nomeou de "exercício da capatazia".

Foi a partir da atribuição de uma importância à ciência humana que o ensino de língua portuguesa obteve benefícios, por todos os conceitos que ela ajudou a formar. Assim, em sala de aula, tanto o objeto de ensino quanto as atividades praticadas com esse objeto foram ressignificadas.

\subsection{As práticas para o ensino de língua portuguesa}


Abordando o texto como objeto de ensino, Geraldi propôs três práticas para o trabalho com o texto: leitura, produção e análise linguística. Dessas práticas, a central, para ele, é a produção de textos, complementada pelas atividades de leitura e de análise linguística. Isso porque, segundo o autor, a atividade de produção constitui-se como elemento essencial, tanto para a linguagem quanto para o sujeito, como condição de reflexão sobre o ensino de língua portuguesa.

Quanto à leitura do texto do aluno, Geraldi propõe que ela aconteça como um possível trabalho com a linguagem visando à produção de textos. Com relação à prática de leitura, para ele, ela deve ser uma “[...] oferta de contrapalavras do leitor que, acompanhando os traços deixados no texto pelo autor, faz estes traços renascerem pelas significações que o encontro das palavras produz" (GERALDI, 2007, p. 41). Ele também considera que a construção de uma prática de leitura que propõe o sujeito como sujeito livre é também uma prática da sociedade.

Geraldi define a leitura como "ato dialógico". Para ele, os professores brasileiros lidam diariamente com dois "milagres" para resolver o problema da leitura na sala de aula: "[...] o milagre de construir o acesso material a livros e o milagre de incentivarem leitores sem poderem ser leitores!" (GERALDI, 1986b, p. 49). Com isso, ficam visíveis dois graves problemas: "[...] as péssimas condições de trabalho do professor que o obrigam a produzir milagres e o nível de degradação a que chegou a educação para que a ordem se estabeleça para a maioria em benefício do progresso da minoria” (p. 49).

Para ele, cada sujeito/aluno é produtor de suas ideias/textos, "produzindo diferenças e singularidades", mesmo que movido por "formações discursivas", no sentido que lhes atribui Foucault (2008).

Geraldi reflete, principalmente, sobre a noção de constitutividade, que abrange o sujeito e a sua "inconclusão", elegendo por objetivo "[...] pôr sob suspeição a esperança que inspira a construção deste horizonte como ponto de chegada" (1992a, p. 26). Sob esse seu ponto de vista, a leitura, para ele, tanto a do mundo quanto a da palavra, é compreendida como "a interação entre os homens".

Quanto à linguagem e a sua constituição, para Geraldi (1991b), “Trata-se de pensar a atividade lingüística não só a partir das ações que se fazem com a linguagem, mas de pensá-la também a partir das ações que se fazem sobre a linguagem e das ações da linguagem” (p. 20, grifos do autor). Assim, segundo ele, “[...] estes três tipos de ações se entrecruzam e se concretizam nos recursos expressivos que, materialmente, as revelam. [...] a linguagem 
permite tais ações em função de uma de suas características essenciais: a reflexividade [...]" (p. 24).

Para tanto, Geraldi menciona que na própria aprendizagem da linguagem, há um ato de reflexão sobre ela mesma.

\subsubsection{A gramática}

O trabalho com o texto na sala de aula, segundo Geraldi, contrapõe-se tanto à prática da atividade da Gramática Tradicional, como atividade meramente descritiva, quanto à utilização do livro didático em sala de aula.

Geraldi (2006d) afirma: "Se surgiu a necessidade de ensinar uma língua para aqueles que a falam como sua língua materna, certamente é porque como a falam não se coaduna com a imagem de como esta língua é ou deveria ser!” (p. 29). Ele afirma que o ensino da gramática na escola é "perda de tempo", e que é preciso contrapor a ele a reflexão sobre a linguagem e sobre o funcionamento da língua portuguesa, por meio das atividades epilinguísticas. Isso porque, "Muito mais do que descrever, trata-se de usar os recursos expressivos. Muito mais do que classificar, trata-se de perceber relações de similitude e diferença" (GERALDI, 2006d, p. 33).

\subsubsection{O livro didático de língua portuguesa}

Uma outra atividade a que se contrapõe a proposta de Geraldi é a utilização do livro didático, para quem esses livros acabam "assujeitando" o trabalho do sujeito. Ele caracteriza o livro didático como: “[...] um livro organizado em lições ou unidades centradas em algum tema previamente selecionado, destinado a um público específico e a uma utilização específica - os alunos e a sala de aula [...]” (GERALDI, 1987b, p. 4).

Para Geraldi, a adoção do livro acaba por "adotar" o professor, que o utiliza como o único recurso para a aula. $\mathrm{O}$ autor ainda comenta que “[...] se houver (e há) problemas na formação de professores, deveríamos atacar diretamente esta questão, e não remendar, tapar o sol com a peneira, com a entrega de livros didáticos" (GERALDI, 1987b, p. 6). A sugestão de Geraldi é que "[...] os professores de língua portuguesa e os professores de linguagem das séries iniciais do $1^{\circ}$. grau deveriam [...] trocar o livro didático pelo livro (sem adjetivos)" (p. 7). 
Para Geraldi, em um trabalho de reflexão sobre a linguagem e de constituição da linguagem e do sujeito, não pode haver "amarras".

\subsection{As parcerias}

Do total de textos publicados por Geraldi, 39 deles foram elaborados em co-autoria (como organizador, coordenador e como co-autor), distribuídos em oito modalidades: livros, capítulos de livro, artigos em periódico, entrevistas, textos em anais, artigos em jornais de notícias, resenhas e traduções, das quais participaram 42 co-autores.

A maior parte dos co-autores de textos com Geraldi é composta, principalmente, por professores/pesquisadores da UNICAMP, ao todo 21: 14 vinculados ao IEL - Celene Margarida Cruz, Conceição Aparecida de Jesus, Eduardo Guimarães, Eliana Maria Severino Donaio Ruiz, Haquira Osakabe, Jesus Antonio Durigan, Jonas de Araújo Romualdo, Liliane Moreira, Maria Bernadete Abaurre, Maria Filomena Spatti Sândalo, Maria Laura MayrinkSabinson, Raquel Salek Fiad, Rodolfo Ilari, Sírio Possenti; cinco vinculados à Faculdade de Educação - Afira Vianna Ripper, Corinta Maria Grisólia Geraldi, Joseane Zaghetti, Lilian Lopes Martin da Silva e Sarita Aparecida Affonso Moysés; um vinculado ao Núcleo Interdisciplinar para a Melhoria do Ensino de Ciências (NIMEC) - Adriano Nogueira; e uma vinculada à Faculdade de Ciências Médicas (FCM)/UNICAMP - Maria Aparecida Affonso Moysés.

Oito professores/pesquisadores, co-autores de textos com Geraldi, estão vinculados à USP: seis vinculados à Faculdade de Filosofia, Letras e Ciências Humanas (FFLCH) Beatriz Helena Marão Citelli, Claudinéia Barbosa de Azevedo, Elisa Duarte Teixeira, Lígia Chiappini $^{139}$, Maria Madalena Iwamoto Sercundes, Marlete Carboni Tardelli; um vinculado à Escola de Comunicação e Artes (ECA) - Adilson Citelli; e uma vinculada à Universidade Cruzeiro do Sul/USP - Guaraciaba Micheletti ${ }^{140}$.

\footnotetext{
${ }^{139}$ Segundo informações que constam em seu currículo, no Sistema de Currículos Lattes, consultado em 20 de novembro de 2009, Lígia Chiappini foi docente na USP até 1997, quando ingressou no Lateinamerika-Institut, na universidade Freie Universitat Berlin, em Berlim/Alemanha, onde trabalha até os dias atuais.

${ }^{140}$ A professora Guaraciaba Micheletti, professora aposentada da USP, é atualmente professora da Universidade Cruzeiro do Sul, segundo informações que constam em seu currículo, no Sistema de Currículos Lattes, consultado em 20 de novembro de 2009.
} 
Quanto aos demais professores/pesquisadores brasileiros, co-autores de textos com Geraldi, destacam-se: vinculada à UNIFRAN/SP, Cecília Azevedo Lima Collares; vinculado à UNINOVE/SP e ao Instituto Paulo Freire/SP, José Eustáquio Romão; vinculada à UFS/Sergipe, Maria Nilma Góes da Fonseca; vinculada ao Instituto de Filosofia e Ciências Humanas/UFRGS, Carla Mauch; vinculado à UNEMAT, Carlos Maldonado; Lurdi Haas, vinculada à Escola "Rita Caldas" da Secretaria Municipal de Cuiabá; e Alessandra Vidotti, Eunice Cesnik, Maria Florentina Camerini e Sandra Leibovici, vinculadas ao Instituto Vigotski.

Dentre os co-autores estrangeiros de textos com Geraldi, destacam-se: Abreu Freire, Ana Isabel Andrade, António Moreira, Cristina Manuela Sá, Isabel Alarcão, Luísa Álvares Pereira, Manuel Bernardo Canha, Maria Helena Ançã, Maria Helena Araújo e Sá, Mario Gamito, Susana Pinto e Teresa Cardoso, vinculados à Universidade de Aveiro (Portugal); Bernd Fichtner, Amauri Lobo e Clemens Knobloch, vinculados à Universidade de Siegen/Alemanha; Maria Benites, também vinculada à Universidade de Siegen/Alemanha e ao Instituto Vigotski/SP; vinculados à FPCEUP/Portugal: Luiza Cortesão, Rosa Nunes e Rui Trindade; vinculados à Universidade de Barcelona/Espanha: Fernando González e Jorge Larrosa.

E, especialmente para a entrevista "Leitura e escrita na escola podem ser livres?" (2005), as parcerias aconteceram também com as crianças: Miréia Larrosa, filha de Jorge Larrosa, e Tomás González e Vera González, filhos de Fernando González, sociólogo espanhol, e Victória Carbó, professora de música em Barcelona/Espanha.

No Quadro 8, apresento os co-autores de textos com Geraldi, que totalizam 65 parcerias, por ordem alfabética de nomes, acompanhados de suas respectivas filiações institucionais. 


\section{Quadro 8-Co-autores de textos com Geraldi, por ordem alfabética de nomes e respectivas filiações institucionais}

\begin{tabular}{|c|c|c|}
\hline OCORRÊNCIA & CO-AUTORES & FILIAÇÃO INSTITUCIONAL \\
\hline 1 & Abreu Freire & Universidade de Aveiro/Portugal \\
\hline 2 & Adilson Citelli & Escola de Comunicação e Artes (ECA)/USP \\
\hline 3 & Adriano Nogueira & $\begin{array}{c}\text { Núcleo Interdisciplinar para a Melhoria do Ensino de } \\
\text { Ciências (NIMEC)/UNICAMP }\end{array}$ \\
\hline 4 & Afira Vianna Ripper & FE/UNICAMP \\
\hline 5 & Alessandra Vidotti & Instituto Vigotski \\
\hline 6 & Amauri Lobo & Univertät Siegen \\
\hline 7 & Ana Isabel Andrade & Universidade de Aveiro/Portugal \\
\hline 8 & António Moreira & Universidade de Aveiro/Portugal \\
\hline 9 & Beatriz Helena Marão Citelli & USP \\
\hline 10 & Bernd Fichtner & Universidade de Siegen/Alemanha \\
\hline 11 & Carla Mauch & Instituto de Filosofia e Ciências Humanas/UFRGS \\
\hline 12 & Carlos Maldonado & UNEMAT \\
\hline 13 & Cecília Azevedo Lima Collares & Universidade de Franca (UNIFRAN)/SP \\
\hline 14 & Celene Margarida Cruz & IEL/ UNICAMP \\
\hline 15 & Claudinéia Barbosa de Azevedo & $\begin{array}{l}\text { Faculdade de Filosofia, Letras e Ciências Humanas } \\
\text { (FFLCH)/USP }\end{array}$ \\
\hline 16 & Clemens Knobloch & $\begin{array}{c}\text { Faculdade de Letras e Literatura da Universität de } \\
\text { Siegen/Alemanha }\end{array}$ \\
\hline 17 & Conceição Aparecida de Jesus & IEL/UNICAMP \\
\hline 18 & Corinta Maria Grisólia Geraldi & FE/UNICAMP \\
\hline 19 & Cristina Manuela Sá & Universidade de Aveiro/Portugal \\
\hline 20 & Eduardo Guimarães & IEL/UNICAMP \\
\hline 21 & $\begin{array}{llll}\text { Eliana } & \text { Maria } & \text { Severino } & \text { Donaio } \\
\text { Ruiz } & & \\
\end{array}$ & IEL/UNICAMP \\
\hline 22 & Elisa Duarte Teixeira & FFLCH/USP \\
\hline 23 & Eni P. Orlandi & IEL/UNICAMP \\
\hline 24 & Eunice Cesnik & Instituto Vigotski \\
\hline 25 & Fernando González & Universidade de Barcelona/Espanha \\
\hline 26 & Guaraciaba Micheletti & Universidade Cruzeiro do Sul/USP \\
\hline 27 & Haquira Osakabe & IEL/UNICAMP \\
\hline 28 & Isabel Alarcão & Universidade de Aveiro/Portugal \\
\hline 29 & Jesus Antonio Durigan & IEL/UNICAMP \\
\hline 30 & Joseane Zaghetti & FE/UNICAMP \\
\hline 31 & José Eustáquio Romão & $\begin{array}{c}\text { Universidade Nove de Julho (UNINOVE)/SP; Instituto Paulo } \\
\text { Freire/SP }\end{array}$ \\
\hline 32 & Jonas de Araújo Romualdo & $\begin{array}{c}\text { IEL/UNICAMP } \\
\end{array}$ \\
\hline 33 & Jorge Larrosa & Universidade de Barcelona/Espanha \\
\hline 34 & Lígia Chiappini & Lateinamerika-Institut/Freie Universitat Berlin \\
\hline 35 & Liliane Moreira & IEL/UNICAMP \\
\hline 36 & Lilian Lopes Martin da Silva & FE/UNICAMP \\
\hline 37 & Luísa Álvares Pereira & Universidade de Aveiro/Portugal \\
\hline
\end{tabular}




\begin{tabular}{|c|l|c|}
\hline 38 & Luiza Cortesão & FPCEUP/Portugal \\
\hline 39 & Lurdi Haas & Escola "Rita Caldas" da Secretaria Municipal de Cuiabá \\
\hline 40 & Manuel Bernardo Canha & Universidade de Aveiro/Portugal \\
\hline 41 & Maria Aparecida Affonso Moysés & Faculdade de Ciências Médicas (FCM)/UNICAMP \\
\hline 42 & Maria Benites & Universidade de Siegen/Alemanha; Instituto Vigotski/SP \\
\hline 43 & Maria Bernadete Abaurre & IEL/UNICAMP \\
\hline 44 & Maria Filomena Spatti Sândalo & IEL/UNICAMP \\
\hline 45 & Maria Florentina Camerini & Universidade de Aveiro/Portugal \\
\hline 46 & Maria Helena Anca & Universidade de Aveiro/Portugal \\
\hline 47 & Maria Helena Araújo e Sá & IEL/UNICAMP \\
\hline 48 & Maria Laura Mayrink-Sabinson & FFLCH/USP \\
\hline 49 & Maria Madalena I. Sercundes & UFS/Sergipe \\
\hline 50 & Maria Nilma Góes da Fonseca & Universidade de Aveiro/Portugal \\
\hline 51 & Mario Gamito & FFLCH/USP \\
\hline 52 & Marlete Carboni Tardelli & - IEL/UNICAMP \\
\hline 53 & Miréia Larrosa & IEL/UNICAMP \\
\hline 54 & Raquel Salek Fiad & FPCEUP/Portugal \\
\hline 55 & Rodolfo Ilari & FPCEUP/Portugal \\
\hline 56 & Rosa Nunes & Instituto Vigotski \\
\hline 57 & Rui Trindade & FE/UNICAMP \\
\hline 58 & Sandra Leibovici & IEL/UNICAMP \\
\hline 59 & Sarita Aparecida Affonso Moysés & Universidade de Aveiro/Portugal \\
\hline 60 & Sírio Possenti & Universidade de Aveiro/Portugal \\
\hline 61 & Susana Pinto & - \\
\hline 62 & Teresa Cardoso & - \\
\hline 63 & Tomás Gonzalez & - \\
\hline 64 & Vera González & \\
\hline 65 & Victoria Carbó & \\
\hline & & \\
\hline
\end{tabular}

Fonte: Bibliografia de e sobre J. W. Geraldi: um instrumento de pesquisa

(PAULA, 2009a) (Apêndice A)

As parcerias com diversos professores/pesquisadores, as quais resultaram na publicação de textos, além da materialização das ideias afins sobre as quais se podia refletir e veicular naquele momento, permitem também a compreensão dos vários embates que antecederam a publicação de cada texto, assim como das relações de co-autoria: co-autores que vêm e vão; co-autores de textos publicados em um determinado momento; co-autores de um único texto; co-autores em âmbito nacional e internacional; vários aspectos advindos das ciências linguísticas e debatidos no momento e ao mesmo tempo; parcerias com exprofessores e colegas de trabalho; co-autores ligados a tema de mesmo interesse.

No Quadro 9, apresento os textos de Geraldi ${ }^{141}$ elaborados em parceria, organizados por co-autores e número de textos.

\footnotetext{
${ }^{141}$ Apresento, em conjunto, os textos elaborados por Geraldi em parceria, sob diferentes modalidades de texto: livros, capítulos de livro, artigos em periódico, entrevistas, textos em anais, artigos em jornais de notícias, resenhas e traduções.
} 


\section{Quadro 9 - Textos de Geraldi em parceria, por co-autores e número de textos}

\begin{tabular}{|c|c|c|c|}
\hline OCOR- & CO-AUTORES & TEXTOS EM CO-AUTORIA & NÚME- \\
\hline 1 & Abreu Freire & Diálogos através de Paulo Freire (2004) & 1 \\
\hline 2 & Adilson Citelli & $\begin{array}{l}\text { "A circulação de textos na escola: primeiros resultados" } \\
(1995)\end{array}$ & 1 \\
\hline 3 & Adriano Nogueira & $\begin{array}{l}\text { Paulo Freire: trabalho, comentário, reflexão (1990) } \\
\text { Paulo Freire: una reflexión sobre la educación, } \\
\text { administración y política en el município de São Paulo, } \\
\text { Brasil (1994) }\end{array}$ & 2 \\
\hline 4 & Afira Vianna Ripper & Janelas para o mundo: diálogo com outras vozes (2006) & 1 \\
\hline 5 & Alessandra Vidotti & Janelas para o mundo: diálogo com outras vozes (2006) & 1 \\
\hline 6 & Amauri Lobo & Janelas para o mundo: diálogo com outras vozes (2006) & 1 \\
\hline 7 & Ana Isabel Andrade & $\begin{array}{l}\text { "Percursos de consolidação da didáctica de línguas em } \\
\text { Portugal..." (2004) }\end{array}$ & 1 \\
\hline 8 & António Moreira & $\begin{array}{l}\text { "Percursos de consolidação da didáctica de línguas em } \\
\text { Portugal..." (2004) }\end{array}$ & 1 \\
\hline 9 & $\begin{array}{l}\text { Beatriz Helena Marão } \\
\text { Citelli }\end{array}$ & $\begin{array}{l}\text { "A circulação escolar de textos produzidos por alunos" } \\
\text { (1995) } \\
\text { Aprender e ensinar com textos de alunos (1997) }\end{array}$ & 2 \\
\hline 10 & Bernd Fichtner & $\begin{array}{l}\text { Transgressões convergentes: Vigotski, Bakhtin, Bateson } \\
\text { (2006) } \\
\text { Janelas para o mundo: diálogo com outras vozes (2006) }\end{array}$ & 2 \\
\hline 11 & Carla Mauch & "Leitura e escrita na escola podem ser livres?" (2005) & 1 \\
\hline 12 & Carlos Maldonado & Janelas para o mundo: diálogo com outras vozes (2006) & 1 \\
\hline 13 & $\begin{array}{l}\text { Cecília Azevedo Lima } \\
\text { Collares }\end{array}$ & $\begin{array}{l}\text { "Educação continuada: a política da descontinuidade" } \\
\text { (1999) } \\
\text { "A integração disciplinar pelo foco das práticas } \\
\text { educativas: uma proposta curricular para um programa } \\
\text { de mestrado" (2000) } \\
\text { "As aventuras do conhecer: da transmissão à } \\
\text { interlocução" (2002) } \\
\text { "Compaginar concepções: ciência e formação no } \\
\text { horizonte de possibilidades de um projeto coletivo" } \\
(2006)\end{array}$ & 4 \\
\hline 14 & Celene Margarida Cruz & $\begin{array}{l}\text { "Orientação argumentativa e pressuposição" (1978) } \\
\text { "Caracterização sumária dos sujeitos falantes no mundo } \\
\text { imaginário de Walt Disney" (1980) } \\
\text { Tradução do artigo "Heterogeneidade(s) enunciativa(s)" } \\
\text { (1990) } \\
\text { Tradução do artigo "Construções relativas e articulações } \\
\text { discursivas" (1990) } \\
\text { Tradução do artigo "Crítica textual e história cultural: o } \\
\text { texto e a voz, séculos XVI-XVII" (1997) }\end{array}$ & 5 \\
\hline
\end{tabular}




\begin{tabular}{|c|c|c|c|}
\hline 15 & $\begin{array}{l}\text { Claudinéia } \quad \text { B. } \quad \text { de } \\
\text { Azevedo }\end{array}$ & $\begin{array}{l}\text { "A circulação escolar de textos produzidos por alunos" } \\
(1995)\end{array}$ & 1 \\
\hline 16 & Clemens Knobloch & Janelas para o mundo: diálogo com outras vozes (2006) & 1 \\
\hline 17 & $\begin{array}{l}\text { Conceição Aparecida de } \\
\text { Jesus }\end{array}$ & $\begin{array}{l}\text { "A circulação escolar de textos produzidos por alunos" } \\
(1995)\end{array}$ & 1 \\
\hline 18 & $\begin{array}{l}\text { Corinta Maria Grisólia } \\
\text { Geraldi }\end{array}$ & $\begin{array}{l}\text { "Avaliação: gestos necessários" (2004) } \\
\text { "Leitura e escrita na escola podem ser livres?" (2005) } \\
\text { "Tecnologias na escola, tecnologias da escola" (2006) } \\
\text { Janelas para o mundo: diálogo com outras vozes (2006) }\end{array}$ & 4 \\
\hline 19 & Cristina Manuela Sá & $\begin{array}{l}\text { "Percursos de consolidação da didáctica de línguas em } \\
\text { Portugal..." (2004) }\end{array}$ & 1 \\
\hline 20 & Eduardo Guimarães & $\begin{array}{l}\text { "Argumentative operators and dialogue" (1985) } \\
\text { "Operadores de argumentação e diálogo" (1985) } \\
\text { Sobre a estruturação do discurso (1981) }\end{array}$ & 3 \\
\hline 21 & $\begin{array}{l}\text { Eliana Maria S. Donaio } \\
\text { Ruiz }\end{array}$ & $\begin{array}{l}\text { "O livro didático de língua portuguesa: didatização e } \\
\text { destruição da atividade lingüística" (1986) } \\
\text { "A destruidora didática dos livros" (1986) }\end{array}$ & 2 \\
\hline 22 & Elisa Duarte Teixeira & $\begin{array}{l}\text { "A circulação escolar de textos produzidos por alunos" } \\
\text { (1995) }\end{array}$ & 1 \\
\hline 23 & Eni Orlandi & Sobre a estruturação do discurso (1981) & 1 \\
\hline 24 & Eunice Cesnik & Janelas para o mundo: diálogo com outras vozes (2006) & 1 \\
\hline 25 & Fernando González & "Leitura e escrita na escola podem ser livres?" (2005) & 1 \\
\hline 26 & Guaraciaba Micheletti & $\begin{array}{l}\text { "A circulação de textos na escola: primeiros resultados" } \\
\text { (1995) }\end{array}$ & 1 \\
\hline 27 & Haquira Osakabe & $\begin{array}{l}\text { "O efeito das palavras" (1982) } \\
\text { "A interlocução no debate político" (1988) }\end{array}$ & 2 \\
\hline 28 & Isabel Alarcão & $\begin{array}{l}\text { "Percursos de consolidação da didáctica de línguas em } \\
\text { Portugal..." (2004) }\end{array}$ & 1 \\
\hline 29 & Jesus Antonio Durigan & Sobre a estruturação do discurso (1981) & 1 \\
\hline 30 & Joseane Zaghetti & Janelas para o mundo: diálogo com outras vozes (2006) & 1 \\
\hline 31 & José Eustáquio Romão & Diálogos através de Paulo Freire (2004) & 1 \\
\hline 32 & $\begin{array}{l}\text { Jonas de Araújo } \\
\text { Romualdo }\end{array}$ & $\begin{array}{l}\text { "O efeito das palavras" (1982) } \\
\text { "A interlocução no debate político" (1988) } \\
\text { Tradução do artigo "Código, uso e fundamentos" (1992) }\end{array}$ & 3 \\
\hline 33 & Jorge Larrosa & "Leitura e escrita na escola podem ser livres?" (2005) & 1 \\
\hline 34 & Lígia Chiappini & $\begin{array}{l}\text { "A circulação de textos na escola: primeiros resultados" } \\
\text { (1995) }\end{array}$ & 1 \\
\hline 35 & Liliane Moreira & "Nem: operador argumentativo?” (1988) & 1 \\
\hline 36 & $\begin{array}{l}\text { Lilian Lopes Martin da } \\
\text { Silva }\end{array}$ & $\begin{array}{l}\text { O ensino de língua portuguesa no } 1^{\circ} \text {. grau: projeto } \\
\text { magistério (1986) } \\
\text { "O livro didático de língua portuguesa: didatização e } \\
\text { destruição da atividade lingüística" (1986) } \\
\text { "A destruidora didática dos livros" (1986) } \\
\text { "Para repensar o ensino de português" (1989) } \\
\text { "Lingüística, ensino de língua materna e formação de } \\
\text { professores" (1996) }\end{array}$ & 5 \\
\hline 37 & Luísa Álvares Pereira & $\begin{array}{l}\text { "Percursos de consolidação da didáctica de línguas em } \\
\text { Portugal..." (2004) }\end{array}$ & 1 \\
\hline 38 & Luiza Cortesão & Diálogos através de Paulo Freire (2004) & 1 \\
\hline 39 & Lurdi Haas & Janelas para o mundo: diálogo com outras vozes (2006) & 1 \\
\hline 40 & Manuel Bernardo Canha & $\begin{array}{l}\text { "Percursos de consolidação da didáctica de línguas em } \\
\text { Portugal..." (2004) }\end{array}$ & 1 \\
\hline 41 & $\begin{array}{l}\text { Maria Aparecida A. } \\
\text { Moysés }\end{array}$ & $\begin{array}{l}\text { "Educação continuada: a política da descontinuidade" } \\
\text { (1999) } \\
\text { "A integração disciplinar pelo foco das práticas } \\
\text { educativas: uma proposta curricular para um programa } \\
\text { de mestrado" (2000) } \\
\text { "As aventuras do conhecer: da transmissão à } \\
\text { interlocução" (2002) }\end{array}$ & 4 \\
\hline
\end{tabular}




\begin{tabular}{|c|c|c|c|}
\hline & & $\begin{array}{l}\text { "Compaginar concepções: ciência e formação no } \\
\text { horizonte de possibilidades de um projeto coletivo" } \\
(2006)\end{array}$ & \\
\hline 42 & Maria Benites & $\begin{array}{l}\text { Transgressões convergentes: Vigotski, Bakhtin, Bateson } \\
\text { (2006) } \\
\text { Janelas para o mundo: diálogo com outras vozes (2006) }\end{array}$ & 2 \\
\hline 43 & Bernadete & $\begin{array}{l}\text { "Considerações sobre a utilização de um paradigma } \\
\text { indiciário na análise de episódios de refacção textual" } \\
(1995) \\
\text { "O caráter singular das operações de refacção nos textos } \\
\text { representativos do início da aquisição da escrita" (1995) }\end{array}$ & 2 \\
\hline 44 & $\begin{array}{l}\text { Maria Filomena Spatti } \\
\text { Sândalo }\end{array}$ & $\begin{array}{l}\text { "Cancelador de implicatura x operador argumentativo: } \\
\text { análise da partícula "hoaga" do Pirahã" (1988) }\end{array}$ & 1 \\
\hline 45 & $\begin{array}{ll}\text { Maria } & \text { Florentina } \\
\text { Camerini } & \end{array}$ & Janelas para o mundo: diálogo com outras vozes (2006) & 1 \\
\hline 46 & Maria Helena Ançã & $\begin{array}{l}\text { "Percursos de consolidação da didáctica de línguas em } \\
\text { Portugal..." (2004) }\end{array}$ & 1 \\
\hline 47 & $\begin{array}{l}\text { Maria Helena Araújo e } \\
\text { Sá }\end{array}$ & $\begin{array}{l}\text { "Percursos de consolidação da didáctica de línguas em } \\
\text { Portugal..." (2004) }\end{array}$ & 1 \\
\hline 48 & $\begin{array}{l}\text { Maria Laura Mayrink- } \\
\text { Sabinson }\end{array}$ & $\begin{array}{l}\text { Resenha do livro No mundo da escrita: uma perspectiva } \\
\text { psicolingüística (1987) } \\
\text { "Considerações sobre a utilização de um paradigma } \\
\text { indiciário na análise de episódios de refacção textual" } \\
\text { (1995) } \\
\text { "O caráter singular das operações de refacção nos textos } \\
\text { representativos do início da aquisição da escrita" (1995) }\end{array}$ & 3 \\
\hline 49 & $\begin{array}{l}\text { Maria Madalena } \mathrm{I} . \\
\text { Sercundes }\end{array}$ & $\begin{array}{l}\text { "A circulação escolar de textos produzidos por alunos" } \\
\text { (1995) }\end{array}$ & 1 \\
\hline 50 & $\begin{array}{l}\text { Maria Nilma Góes da } \\
\text { Fonseca }\end{array}$ & "O circuito do livro e a escola" (1984) & 1 \\
\hline 51 & Mario Gamito & $\begin{array}{l}\text { "Percursos de consolidação da didáctica de línguas em } \\
\text { Portugal..." (2004) }\end{array}$ & 1 \\
\hline 52 & $\begin{array}{ll}\text { Marlete } & \text { Carboni } \\
\text { Tardelli } & \\
\end{array}$ & $\begin{array}{l}\text { "A circulação escolar de textos produzidos por alunos" } \\
\text { (1995) }\end{array}$ & 1 \\
\hline 53 & Miréia Larrosa & "Leitura e escrita na escola podem ser livres?" (2005) & 1 \\
\hline 54 & Raquel Salek Fiad & $\begin{array}{l}\text { O ensino de língua portuguesa no } 1^{\circ} \text {. grau: projeto } \\
\text { magistério (1986) } \\
\text { "O livro didático de língua portuguesa: didatização e } \\
\text { destruição da atividade lingüística" (1986) } \\
\text { "A destruidora didática dos livros" (1986) } \\
\text { "Para repensar o ensino de português" (1989) } \\
\text { "A sala de aula é uma oficina de dizer coisas" (1994) } \\
\text { "Considerações sobre a utilização de um paradigma } \\
\text { indiciário na análise de episódios de refacção textual" } \\
\text { (1995) } \\
\text { "O caráter singular das operações de refacção nos textos } \\
\text { representativos do início da aquisição da escrita" (1995) } \\
\text { "Lingüística, ensino de língua materna e formação de } \\
\text { professores" (1996) }\end{array}$ & 8 \\
\hline 55 & Rodolfo Ilari & $\begin{array}{l}\text { Semântica (1985) } \\
\text { "Argumentative operators and dialogue" (1985) } \\
\text { "Operadores de argumentação e diálogo" (1985) }\end{array}$ & 3 \\
\hline 56 & Rosa Nunes & Diálogos através de Paulo Freire (2004) & 1 \\
\hline 57 & Rui Trindade & Diálogos através de Paulo Freire (2004) & 1 \\
\hline 58 & Sandra Leibovici & Janelas para o mundo: diálogo com outras vozes (2006) & 1 \\
\hline 59 & $\begin{array}{l}\text { Sarita Aparecida A. } \\
\text { Moysés }\end{array}$ & $\begin{array}{l}\text { O ensino de língua portuguesa no } 1^{\circ} . \text { grau: projeto } \\
\text { magistério (1986) }\end{array}$ & 1 \\
\hline 60 & Sírio Possenti & $\begin{array}{l}\text { "O efeito das palavras" (1982) } \\
\text { "A interlocução no debate político" (1988) }\end{array}$ & 3 \\
\hline
\end{tabular}




\begin{tabular}{|c|l|l|c|}
\hline & & Sobre a estruturação do discurso (1981) & 1 \\
\hline 61 & Susana Pinto & $\begin{array}{l}\text { "Percursos de consolidação da didáctica de línguas em } \\
\text { Portugal...” (2004) }\end{array}$ & 1 \\
\hline 62 & Teresa Cardoso & $\begin{array}{l}\text { "Percursos de consolidação da didáctica de línguas em } \\
\text { Portugal...” (2004) }\end{array}$ & 1 \\
\hline 63 & Tomás Gonzalez & “Leitura e escrita na escola podem ser livres?” (2005) & 1 \\
\hline 64 & Vera González & "Leitura e escrita na escola podem ser livres?” (2005) & 1 \\
\hline 65 & Victoria Carbó & "Leitura e escrita na escola podem ser livres?” (2005) & 1 \\
\hline TOTAL DE TEXTOS POR CO-AUTOR &
\end{tabular}

Fonte: Bibliografia de e sobre J. W. Geraldi: um instrumento de pesquisa (PAULA, 2009a) (Apêndice A)

Destaca-se, em número de ocorrência, os oito textos publicados em co-autoria com Raquel Salek Fiad, os quais abordam o ensino de língua portuguesa: $O$ ensino de língua portuguesa no $1^{\circ}$. grau: projeto magistério (1986), "O livro didático de língua portuguesa: didatização e destruição da atividade lingüística" (1986), "A destruidora didática dos livros" (1986), "Para repensar o ensino de português" (1989), “A sala de aula é uma oficina de dizer coisas" (1994), "Considerações sobre a utilização de um paradigma indiciário na análise de episódios de refacção textual” (1995), “O caráter singular das operações de refacção nos textos representativos do início da aquisição da escrita" (1995) e "Lingüística, ensino de língua materna e formação de professores" (1996).

Em co-autoria com Lílian Lopes Martin da Silva, também sobre o ensino de língua portuguesa, destacam-se cinco textos: $O$ ensino de língua portuguesa no $1^{o}$. grau: projeto magistério (1986), "O livro didático de língua portuguesa: didatização e destruição da atividade lingüística” (1986), “A destruidora didática dos livros” (1986), "Para repensar o ensino de português" (1989) e "Lingüística, ensino de língua materna e formação de professores" (1996).

Com Celene Margarida Cruz, também foram publicados cinco textos. Dentre eles, os textos: "Orientação argumentativa e pressuposição" (1978) e "Caracterização sumária dos sujeitos falantes no mundo imaginário de Walt Disney" (1980) abordam questões descritivas da linguagem; e os outros três são traduções dos artigos: Heterogeneidade(s) enunciativa(s)" (1990), “Construções relativas e articulações discursivas" (1990) e "Crítica textual e história cultural: o texto e a voz, séculos XVI-XVII” (1997).

Em co-autoria com Cecília Azevedo Lima Collares e Maria Aparecida A. Moysés, foram publicados quatro textos: "Educação continuada: a política da descontinuidade" (1999), "A integração disciplinar pelo foco das práticas educativas: uma proposta curricular para um programa de mestrado" (2000), "As aventuras do conhecer: da transmissão à interlocução" (2002) e "Compaginar concepções: ciência e formação no horizonte de possibilidades de um 
projeto coletivo" (2006). Também em co-autoria com a professora/pesquisadora Corinta Maria Grisólia Geraldi, foram publicados quatro textos: "Avaliação: gestos necessários" (2004), "Leitura e escrita na escola podem ser livres?” (2005), “Tecnologias na escola, tecnologias da escola" (2006) e Janelas para o mundo: diálogo com outras vozes (2006).

Com os professores/pesquisadores Jonas de Araújo Romualdo, Rodolfo Ilari, Maria Laura Mayrink-Sabinson, Sírio Possenti e Eduardo Guimarães, foram publicados três textos. Com Jonas de Araújo Romualdo, foram publicados os textos: "O efeito das palavras" (1982), “A interlocução no debate político" (1988) e a tradução do artigo "Código, uso e fundamentos" (1992); com Rodolfo Ilari: Semântica (1985), “Argumentative operators and dialogue" (1985) e "Operadores de argumentação e diálogo" (1985); com Maria Laura Mayrink-Sabinson: a resenha do livro No mundo da escrita: uma perspectiva psicolingüística (1987), "Considerações sobre a utilização de um paradigma indiciário na análise de episódios de refacção textual” (1995) e "O caráter singular das operações de refacção nos textos representativos do início da aquisição da escrita" (1995); com Sírio Possenti, foram publicados os textos: "O efeito das palavras" (1982), "A interlocução no debate político" (1988) e Sobre a estruturação do discurso (1981); e com Eduardo Guimarães, os textos: “Argumentative operators and dialogue" (1985), "Operadores de argumentação e diálogo" (1985) e Sobre a estruturação do discurso (1981).

Os professores/pesquisadores Adriano Nogueira, Beatriz Helena Marão Citelli, Bernd Fichtner, Eliana Maria Severino Donaio Ruiz, Haquira Osakabe, Maria Benites, Maria Bernadete Abaurre tiveram publicados dois textos em co-autoria com Geraldi. Em co-autoria com Adriano Nogueira, foram publicados: Paulo Freire: trabalho, comentário, reflexão (1990) e Paulo Freire: una reflexión sobre la educación, administración y política en el município de São Paulo, Brasil (1994); com Beatriz Helena Marão Citelli: “A circulação escolar de textos produzidos por alunos" (1995) e Aprender e ensinar com textos de alunos (1997); com Bernd Fichtner: Transgressões convergentes: Vigotski, Bakhtin, Bateson (2006) e Janelas para o mundo: diálogo com outras vozes (2006); com Eliana Maria Severino Donaio Ruiz: "O livro didático de língua portuguesa: didatização e destruição da atividade lingüística" (1986) e “A destruidora didática dos livros” (1986); com Haquira Osakabe: "O efeito das palavras" (1982) e "A interlocução no debate político" (1988); com Maria Benites: Transgressões convergentes: Vigotski, Bakhtin, Bateson (2006) e Janelas para o mundo: diálogo com outras vozes (2006); e com Maria Bernadete Abaurre: "Considerações sobre a utilização de um paradigma indiciário na análise de episódios de refacção textual" (1995) e 
“O caráter singular das operações de refacção nos textos representativos do início da aquisição da escrita" (1995).

Com apenas um texto publicado em co-autoria com Geraldi, destacam-se 49 professores/pesquisadores: Eni P. Orlandi e Jesus Antonio Durigan, com a publicação do livro Sobre a estruturação do discurso (1981); Maria Nilma Góes da Fonseca, com a publicação do artigo "O circuito do livro e a escola" (1984); e Sarita Aparecida A. Moysés, com a publicação do livro $O$ ensino de língua portuguesa no $1^{\circ}$. grau: projeto magistério (1986); Liliane Moreira, com a publicação do artigo “Nem: operador argumentativo?” (1988); Maria Filomena Spatti Sândalo, com a publicação do artigo "Cancelador de implicatura x operador argumentativo: análise da partícula "hoaga" do Pirahã" (1988); Claudinéia B. de Azevedo, Conceição Aparecida de Jesus, Elisa Duarte Teixeira, Maria Madalena Sercundes e Marlete Carboni Tardelli, com a publicação do artigo "A circulação escolar de textos produzidos por alunos" (1995); Adilson Citelli, Guaraciaba Micheletti e Lígia Chiappini, com a publicação do artigo "A circulação de textos na escola: primeiros resultados" (1995); Abreu Freire, José Eustáquio Romão, Luiza Cortesão, Rosa Nunes e Rui Trindade, com a publicação do livro Diálogos através de Paulo Freire (2004); Ana Isabel Andrade, António Moreira, Cristina Manuela Sá, Isabel Alarcão, Luísa Álvares Pereira, Manuel Bernardo Canha, Maria Helena Ançã, Maria Helena Araújo e Sá, Mário Gamito, Susana Pinto e Teresa Cardoso, com a publicação do artigo "Percursos de consolidação da didáctica de línguas em Portugal: análise dos estudos realizados no âmbito das unidades de investigação, subsidiadas pela Fundação para a Ciência e Tecnologia, na área das ciências da educação" (2004); Carla Mauch, Fernando González, Jorge Larrosa, Miréia Larrosa, Tomás González, Vera González e Victoria Carbó, com a publicação da entrevista "Leitura e escrita na escola podem ser livres?" (2005); e Afira Vianna Ripper, Alessandra Vidotti, Amauri Lobo, Carlos Maldonado, Clemens Knobloch, Eunice Cesnik, Joseane Zaghetti, Lurdi Haas, Maria Florentina Camerini e Sandra Leibovici, com a publicação do livro Janelas para o mundo: diálogo com outras vozes (2006).

Da mesma forma, é possível considerar o momento em que as inúmeras parcerias estabelecidas por Geraldi ocorreram: momentos de acirrados embates entre as diferentes concepções linguísticas, de constituição do IEL, e também de busca de soluções para os problemas da educação em geral, e, sobretudo, para o ensino de língua portuguesa.

É inegável também a representatividade do movimento alçado, pelo percurso de Geraldi, do Brasil para o exterior, o que revela o reconhecimento de um grande trabalho, “desestabilizador de certezas", nas palavras de Geraldi. 
No entanto, é preciso considerar também as parcerias que não foram vistas pelo leitor: as constituídas para inúmeras palestras, eventos e cursos de longa e de curta duração, assim como os convites e as conversas de corredores de que Geraldi participou, parcerias estas que não foram publicadas, mas auxiliaram e motivaram as reflexões suscitadas e propostas no percurso de seu pensamento sobre o ensino de língua portuguesa.

Essas reflexões e embates com professores, orientandos, colegas e amigos, foram sendo estabelecidas com a geração com a qual Geraldi dialogou/dialoga, primeiramente para a execução de projetos, assim como para a apresentação em eventos, cujos resultados foram registrados em seus textos.

Essas parcerias com diferentes professores/pesquisadores indicam o movimento de seu trabalho, nos momentos que antecederam a publicação e naqueles em que ela ocorreu; seus textos materializam as diversas ações estabelecidas com esses professores/pesquisadores, as quais refletem, dentre outras, prioritariamente sobre a linguagem e o seu ensino.

Geraldi integra, sobretudo, um grupo de pesquisadores unicampianos, que, naquele momento, década de 1980, articulava questões que se faziam imprescindíveis ao ensino. Do interior do IEL, onde ele se formou e atuou, as concepções que embasaram seu pensamento foram de natureza linguística.

No entanto, essas parcerias não ficaram restritas ao seu meio imediato, pois se estenderam tanto a faculdades unicampianas, principalmente com a Faculdade de Educação, quanto a outros professores/pesquisadores das universidades de todo o Brasil, com destaque para a USP, para onde Geraldi também foi convidado para atuar, constituindo parcerias com diferentes professores/pesquisadores.

Constata-se que, por todos esses movimentos, o trabalho de Geraldi sobre o ensino de língua portuguesa ganhou reconhecimento, tanto em âmbito nacional quanto internacional, estabelecendo "encontros"

Nessas parcerias, certamente Geraldi compreendeu a melhor forma de enxergar e responder as suas dúvidas e também com esses professores/pesquisadores entendeu o “desabrochar", utilizando a metáfora bakhtiniana correspondente ao excedente de visão, que é:

[...] o broto em que repousa a forma e de onde ela desabrocha como uma flor. Mas para que esse broto efetivamente desabroche na flor da forma concludente, urge que o excedente de minha visão complete o horizonte do outro indivíduo contemplado sem perder a originalidade deste. Eu devo

${ }^{142}$ Esse termo que utilizo aqui foi empregado por Geraldi em: "Paulo Freire e Mikhail Bakhtin: o encontro que não houve" (2003). 
entrar em empatia com esse outro indivíduo, ver axiologicamente o mundo de dentro dele tal qual ele o vê, colocar-me no lugar dele e, depois de ter retornado ao meu lugar, completar o horizonte dele com o excedente de visão que desse meu lugar se descortina fora dele, convertê-lo, criar para ele um ambiente concludente a partir desse excedente da minha visão, do meu conhecimento, da minha vontade e do meu sentimento. (BAKHTIN, 2003, p. 23)

Essa é, com certeza, a característica essencial da proposta de Geraldi para o ensino de língua portuguesa, que a distingue das demais que possuem o texto como objeto: a incompletude do sujeito. 
CAPÍTULO 4

APRESENTAÇÃO DA BIBLIOGRAFIA

SOBRE J. W. GERALDI 


\subsection{Bibliografia sobre J. W. Geraldi ${ }^{143}$}

O grande número de textos que tematizam a atuação de Geraldi no ensino de língua portuguesa no Brasil é um indício do espaço e reconhecimento que sua proposta vem ganhando ao longo de sua divulgação. No período compreendido entre 1981 (ano de publicação do primeiro texto sobre Geraldi) e 2008 (ano de elaboração de um capítulo de livro sobre ele), portanto, ao longo de 27 anos, foram publicados 28 textos que abordam sua proposta para o ensino de língua portuguesa ${ }^{144}$.

Esses textos foram publicados sob sete diferentes tipos de texto/forma de participação, apresentando-se como: capítulos de livros: 4; artigo em periódico: 1; resenhas: 2; prefácios e apresentações: 7; orelhas de livros: 5; periódico: 1; dissertações e teses: 8.

Apresento, no quadro 10, os textos sobre Geraldi, por tipo de texto/forma de participação e quantidade de textos.

Quadro 10 - Bibliografia sobre João Wanderley Geraldi,

por tipo de texto/forma de participação e quantidade de texto

\begin{tabular}{|c|c|}
\hline TIPO DE TEXTO & QUANTIDADE \\
\hline Capítulos de livros & 4 \\
\hline Artigos em periódicos & 1 \\
\hline
\end{tabular}

\footnotetext{
${ }^{143}$ Com atualizações, destaco, neste capítulo, aspectos bibliográficos sobre J. W. Geraldi, apresentados em minha dissertação de mestrado (PAULA, 2004a).

144 As referências completas de todos os textos sobre Geraldi se encontram no instrumento de pesquisa Bibliografia de e sobre João Wanderley Geraldi: um instrumento de pesquisa (PAULA, 2009a), em Apêndice a esta tese (Apêndice A).
} 


\begin{tabular}{|c|c|}
\hline Resenhas & 2 \\
\hline Prefácios e apresentações & 7 \\
\hline Orelhas de livros & 5 \\
\hline Periódicos & 1 \\
\hline Dissertações e teses & 8 \\
\hline TOTAL & $\mathbf{2 8}$ \\
\hline
\end{tabular}

Fonte: Bibliografia de e sobre J. W. Geraldi: um instrumento de pesquisa

(PAULA, 2009a) (Apêndice A)

Os quatro capítulos de livros publicados sobre Geraldi foram: "O professor: um profissional para si" (1990), de Paulo Freire; "Sujeito da linguagem, sujeito de ensino" (1997), de Luiz Percival de Leme Britto; “Alfabetização: construtivismo e desmetodização" (2000), de Maria do Rosário Longo Mortatti; e "O texto no ensino-aprendizagem de línguas hoje: desafios da contemporaneidade" (2008), de Roxane Helena R. Rojo, cujas referências completas se encontram em apêndice (Apêndice A).

$\mathrm{O}$ artigo "Uma proposta para o próximo milênio: o pensamento interacionista sobre alfabetização" (1999), de Maria do Rosário Longo Mortatti, foi publicado em Presença pedagógica.

Com relação às resenhas, foram publicadas: a do livro Semântica, de Geraldi e Rodolfo Ilari, elaborada por Lucia Maria Pinheiro Lobato e publicada em 1987; e a resenha do livro Portos de passagem, de Geraldi, elaborada por Rosa Maria Bueno Fischer e publicada em 1992.

Quanto aos prefácios e apresentações, dois foram publicados como prefácios: por Iara Benquerer Costa, o prefácio a "Subsídios metodológicos para o ensino de língua portuguesa: 5a. a 8 . Séries" (1981); e por Carlos Franchi, o prefácio a Portos de passagem (1991); e cinco, como apresentações: por Eleonora Cavalcante Albano, a apresentação a Cadernos de estudos lingüísticos, intitulado 15 anos de Cadernos: um trabalho de João Wanderley Geraldi (1993), publicado em homenagem ao organizador; por Antonio Augusto G. Batista, a apresentação da entrevista "Recuperando as práticas de interlocução na sala de aula" (1998); por Roxane Rojo e Glaís Sales Cordeiro, a apresentação ao livro Gêneros orais e escritos na escola (2004), uma compilação de textos de Bernard Schneuwly e Joaquim Dolz, traduzidos por Roxane Rojo e Glaís Sales Cordeiro, em que as tradutoras mencionam a importância da 
proposta de Geraldi para o ensino de língua portuguesa; por Rosa Nunes, a apresentação do capítulo de livro "Paulo Freire e Mikhail Bakhtin: o encontro que não houve" (2004); e por Maria Helena de Araújo e Sá, a apresentação ao livro A aula como acontecimento (2004).

Como orelhas de livros, foram publicados em $O$ texto na sala de aula (2005), destacando-se, na primeira orelha, os textos de: Valdir Heitor Barzotto, Marinalva Barbosa e Rosa Hessel; na segunda orelha, os de: Sírio Possenti e Norma Shirakura.

As dissertações (quatro) e as teses (quatro) sobre Geraldi, totalizando oito, foram defendidas: dissertações - A construção cotidiana de uma proposta de ensino: as falas de professores e alunos de LP do oeste do Paraná (1991), defendida por Maria Raquel Aparecida Coelho Galan; Ensino de língua portuguesa: ecos de um discurso (1997), defendida por Maria Nilma Góis da Fonseca; Leitura e escrita: a captura de um objeto de ensino (1999), defendida por Altair Pivovar; e $O$ ensino de língua portuguesa no Brasil, segundo João Wanderley Geraldi (2004), defendida por mim, como já mencionado. Quanto às teses, foram defendidas: Mudar o ensino de língua portuguesa: uma promessa que não venceu nem se cumpriu mas que merece ser interpretada (1994), defendida por Lilian Lopes Martin da Silva; Documentos desemboscados: conflito entre o gênero do discurso e a concepção de linguagem nos documentos curriculares de ensino de língua portuguesa (1999), defendida por Guilherme do Val Toledo Prado; A oficialização de novas concepções para o ensino de português no Brasil (2001), defendida por Marildes Marinho; e Perpétua prisão órfica ou Ênio tinha três corações: o relativismo lingüístico e o aspecto criativo da linguagem (2008), defendida por Rodrigo Tadeu Gonçalves.

No quadro 11, a seguir, ordenados por tipo de texto e ano de publicação, apresento os textos sobre Geraldi, produzidos no período compreendido entre 1981 e 2008.

Quadro 11 - Bibliografia sobre João Wanderley Geraldi, por tipo de texto e ano de publicaçã $0^{145}$

\begin{tabular}{|c|c|c|c|c|c|c|c|c|}
\hline $\begin{array}{l}\text { Tipo de texto } \\
\text { Ano de } \\
\text { Publicação }\end{array}$ & $\begin{array}{c}\text { Capítulos } \\
\text { de } \\
\text { Livros }\end{array}$ & $\begin{array}{l}\text { Artigo em } \\
\text { periódico }\end{array}$ & $\begin{array}{l}\text { Rese- } \\
\text { nhas }\end{array}$ & $\begin{array}{l}\text { Prefácios e } \\
\text { apresenta- } \\
\text { ções }\end{array}$ & $\begin{array}{l}\text { Orelhas } \\
\text { de livro }\end{array}$ & Periódico & $\begin{array}{c}\text { Disserta- } \\
\text { ções e } \\
\text { teses }\end{array}$ & $\begin{array}{c}\text { TOTAL } \\
\text { POR } \\
\text { ANO }\end{array}$ \\
\hline 1981 & - & - & - & 1 & - & - & - & 1 \\
\hline 1987 & - & - & 1 & - & - & - & - & 1 \\
\hline 1991 & - & - & - & 1 & - & - & 1 & 2 \\
\hline 1992 & - & - & 1 & - & - & - & - & 1 \\
\hline 1993 & - & - & - & 1 & - & 1 & - & 2 \\
\hline 1994 & - & - & - & - & - & - & 1 & 1 \\
\hline 1997 & 1 & - & - & - & - & - & 1 & 2 \\
\hline
\end{tabular}

\footnotetext{
${ }^{145}$ Também neste quadro foram consideradas apenas as primeiras edições de cada texto publicado.
} 


\begin{tabular}{|l|l|l|l|l|l|l|l|l|}
\hline $\mathbf{2 0 0 1}$ & - & - & - & - & - & - & 1 & 1 \\
\hline $\mathbf{2 0 0 2}$ & - & - & - & - & - & - & - & - \\
\hline $\mathbf{2 0 0 3}$ & - & - & - & - & - & - & - & - \\
\hline $\mathbf{2 0 0 4}$ & - & - & - & 2 & - & - & 1 & $\mathbf{3}$ \\
\hline $\mathbf{2 0 0 5}$ & - & - & - & - & 5 & - & - & $\mathbf{5}$ \\
\hline $\mathbf{2 0 0 6}$ & - & - & - & - & - & - & - & - \\
\hline $\mathbf{2 0 0 7}$ & 1 & - & - & - & - & - & - & $\mathbf{1}$ \\
\hline $\mathbf{2 0 0 8}$ & 1 & - & - & - & - & - & 1 & $\mathbf{2}$ \\
\hline
\end{tabular}

Fonte: Bibliografia de e sobre $J$. W. Geraldi: um instrumento de pesquisa PAULA, 2009a) (Apêndice A)

O primeiro texto sobre Geraldi publicado em 1981 foi o prefácio de Iara Benquerer Costa no periódico "Subsídios metodológicos...", publicado em Cadernos da FIDENE; e os dois textos mais recentes, o capítulo de Roxane Rojo, intitulado "O texto no ensinoaprendizagem de línguas hoje: desafios da contemporaneidade", publicado em 2008 no livro Gêneros de texto: caracterização e ensino, organizado por Luiz Carlos Travaglia, Luísa Helena Borges Finotti e Elisete Maria de Carvalho Mesquita, pela Editora da Universidade Federal de Uberlândia (EDUFU), e a tese de doutorado de Rodrigo Tadeu Gonçalves, intitulada Perpétua prisão órfica ou Ênio tinha três corações: o relativismo lingüístico e o aspecto criativo da linguagem, defendida na UFPR, sob a orientação de José Borges Neto.

Com relação aos textos sobre Geraldi, 25 tematizam diretamente sua proposta para o ensino de língua portuguesa. Os outros três: a resenha elaborada por Lúcia Maria Pinheiro Lobato, a apresentação a Cadernos de estudos lingüísticos e a apresentação do capítulo "Paulo Freire e Mikhail Bakhtin: o encontro que não houve" (2004), por Rosa Nunes, tematizam, respectivamente, o livro Semântica e as reflexões nele contidas, acerca da área da linguagem contemplada no título; o trabalho realizado por Geraldi como organizador do periódico e o "encontro" das ideias freireanas e bakhtinianas, proposto por Geraldi no capítulo por elas apresentado.

\subsection{Textos sobre a proposta de Geraldi para o ensino de língua portuguesa}

Com relação aos textos sobre a proposta de Geraldi para o ensino de língua portuguesa, eles foram elaborados por professores/pesquisadores que participaram ou tiveram conhecimento da importância da representatividade desse lugar de encontro entre linguagem e ensino, característica primordial da proposta de Geraldi para o ensino de língua portuguesa. 
Esses professores/pesquisadores apresentam, em comum com Geraldi, o mesmo interesse: o encontro entre as concepções linguísticas e educacionais.

Dentre os professores/pesquisadores que discutiram a proposta geraldiana, destacamse: seu orientador de doutorado; colaboradores e participantes de sua proposta; orientandos de seus colaboradores; alunos dos cursos de pós-graduação; ex-orientandos; orientandos de exorientandos; colegas da UNICAMP e também de outras instituições brasileiras.

Desses, Carlos Franchi foi orientador da tese de doutorado de Geraldi, assim como anteriormente informado. Iara Benquerer Costa, Lilian Lopes Martin da Silva, Maria Nilma Goes da Fonseca, Raquel Salek Fiad e Maria do Rosário Longo Mortatti foram colaboradoras de Geraldi na divulgação de sua proposta. Dentre seus colegas da UNICAMP, destacam-se: Eleonora Cavalcante Albano, Maria Laura Mayrink-Sabinson, Paulo Freire e Roxane Rojo. Dentre os orientandos de seus colegas, destacam-se: Guilherme do Val Toledo Prado, orientado por Fiad; Marildes Marinho, por Possenti; e Glaís Cordeiro, por Rojo. Foram orientandos de Geraldi: Maria do Rosário Longo Mortatti, Luiz Percival de Leme Britto, Valdir Heitor Barzotto e Marinalva Barbosa; e, dentre os orientandos de uma ex-orientanda, Maria do Rosário Longo Mortatti, incluo-me. Dos alunos dos cursos ministrados por Geraldi, destacam-se: Antonio Augusto G. Batista e Maria Helena de Araújo Sá. Maria Raquel Aparecida Coelho Galan participou do "Projeto do Wanderley"146, desenvolvido no oeste do Paraná. Altair Pivovar foi orientando de Carlos Alberto Faraco, que possui um texto publicado em O texto na sala de aula (1984). Rosa Maria Bueno Fischer, Rosa Hessel e Norma Shirakura são professoras de universidades brasileiras e, possivelmente, participaram de seus cursos e palestras. Rodrigo Tadeu Gonçalves foi orientando de José Borges Neto, colega de Geraldi da UFPR.

Em seus textos, esses professores/pesquisadores registram palavras ou expressões referentes à contribuição da proposta de Geraldi para o ensino de língua portuguesa: "revolução", para Freire (1990); "novos comprometimentos", para Franchi (1991); “invasão

${ }^{146}$ Assim como se refere Mortatti (2000), a proposta de Geraldi para o ensino de língua portuguesa ficou conhecida entre os professores que dele participavam como: "Projeto "Unidades Básicas para o ensino de Português", ou "Projeto do Wanderley", ou "Projeto das Três Práticas". Nesta tese, refiro-me à nomenclatura "Projeto do Wanderley" para indicá-lo. Ressalto ainda que, o "Projeto do Wanderley", como menciona Silva (1994), surgiu em meio ao seu pensamento sobre teoria e prática de ensino, após a conclusão do mestrado no IEL/UNICAMP, quando retorna a FIDENE, instituição da qual se afastou por ocasião do mestrado, para ministrar aulas. Dessas reflexões, surgiu "Subsídios...", a partir do qual Geraldi passou a dialogar com professores de língua portuguesa sobre as ideias que nele apresentava. Suas ideias eram divulgadas inicialmente em cursos rápidos, que passaram a ter uma duração mais prolongada, pela necessidade de aprofundamentos das concepções que Geraldi apresentava, e a partir de então, segundo Silva (1994), “[...] surgirão os Projetos, no interior dos quais grupos de professores debaterão suas ideias, suas práticas e suas dificuldades, motivados ora pela palavra e experiência de seus pares, ora pela nossa palavra, cuja 'força' os deixará 'curiosos', 'interessados', 'eufóricos' e os fará 'acreditarem', como eles mesmos dizem.” (p. 71) 
do discurso pelo próprio discurso", para Fischer (1992); "articulação de concepções lingüísticas com o ensino da língua", para Silva (1994); "reconceitualização", para Fonseca (1997); “união de teoria e prática no ensino”, para Britto (1997); “divisor d'águas”, para Batista (1998); e "revolução conceitual", para Maria do Rosário Longo Mortatti (1999b/2000).

As análises desses professores/pesquisadores sobre a proposta de Geraldi foram alguns dos fatores que, dentre outros, auxiliaram-me na compreensão do pioneirismo de seu pensamento para o ensino de língua portuguesa, partindo da concepção interacionista da linguagem, pensamento esse que denomino "revolução lingüística no ensino de língua portuguesa".

Analisando especialmente "Subsídios metodológicos para o ensino de língua portuguesa: 5a a 8 ${ }^{\text {a }}$ séries" (1981), publicado em Cadernos da FIDENE, Costa (1981), Silva (1994) e Fonseca (1997) tiveram publicados textos em que tematizam a proposta de Geraldi.

Segundo Costa, em prefácio a esse periódico, o ensino da língua necessitava de uma proposta tal como a apresentada por Geraldi em "Subsídios...". A autora, criticando o trabalho que era realizado no ensino antes de "Subsídios...", que partia de "manuais didáticos", considera que a proposta de Geraldi representa "[...] um apelo e uma manifestação de confiança nos professores de $1^{\circ}$. grau” (COSTA, 1981, p. I), numa tentativa de mudar os paradigmas do ensino da língua, apresentando duas "novidades": o texto como novo objeto e uma concepção diferenciada de linguagem. No periódico, segundo a autora, há:

[...] algumas respostas às inúmeras solicitações sempre imediatistas que perseguem o professor universitário, tanto no seu trabalho em cursos superiores quanto em cursos de atualização de professores: "Que fazer hoje, na situação concreta de nossas escolas e com o grau de preparação acadêmica de nossos professores, para por um pouco de ordem no caos que vem sendo o ensino de língua portuguesa?" (COSTA, 1981, p. I)

Também abordando "Subsídios metodológicos...”, Lílian Lopes Martin da Silva defendeu sua tese de doutorado, Mudar o ensino de lingua portuguesa: uma promessa que não venceu nem se cumpriu mas que merece ser interpretada, em 1994, a qual foi apresentada à FE/UNICAMP, sob a orientação de Raquel Salek Fiad. Sobre a proposta, a autora salienta que articulava concepções linguísticas com o ensino da língua, partindo da concepção de linguagem como interação e da produção do texto como eixo central para a prática do ensino. Sobre o projeto de Geraldi, Silva (1994) conclui:

Mais do que julgada, a história que vivemos com os professores através dos projetos aqui relatados precisa ser compreendida em sua dupla face: numa dela vemos o início de uma mudança nas práticas de ensino de língua 
portuguesa no $1^{\mathrm{o}}$. Grau e nas práticas de formação continuada, fundada num conjunto de diretrizes por nós formuladas e compartilhadas com os professores. $\mathrm{Na}$ outra vemos os obstáculos e impedimentos colocados ao projeto político e pedagógico que se insinuava e desenhava lentamente.

$\mathrm{O}$ fato dos projetos terem se encerrado um dia; de muitos grupos terem se desmantelado; de muitos trabalhos terem sido interrompidos ou marcados por inconsistências e contradições; das mudanças não terem acontecido com a dimensão que um dia sonhamos; da surpresa e do desconforto que experimentamos quando ainda hoje encontramos entre os professores os mesmos preconceitos e as mesmas concepções contra as quais nos posicionamos há 10 anos atrás; e de nos sentirmos derrotados por sermos hoje o país campeão mundial do analfabetismo... Todos esses fatos não transformam os acontecimentos aqui recuperados e relatados em algo que não aconteceu, ou em "meras ilusões", como diria Sader (1988): "são promessas que não venceram nem se cumpriram". (SILVA, 1994, p. 331)

Também Maria Nilma Goes da Fonseca analisa a proposta geraldiana, tomando por base "Subsídios metodológicos...", a qual apresenta em sua dissertação de mestrado Ensino de língua portuguesa: ecos de um discurso, em 1997. Sua dissertação foi defendida junto ao Programa de Pós-Graduação em Educação da UFS, sob a orientação de Geraldi. Com relação à atuação de seu orientador, Fonseca (1997) afirma:

Dentre os pioneiros que procuraram associar a teoria lingüística ao ensino de língua materna, para que se faça justiça, devemos citar o professor Geraldi. Suas obras são fontes de referência obrigatórias a quem quiser entender, não só a movimentação ocorrida em diversos Estados - Sergipe, Paraná, Mato Grosso, Goiás, Piauí, Alagoas etc - como também os principais fatos e idéias que marcaram a reconceitualização do ensino de língua presente na maioria dos planos curriculares das diversas Secretarias de Educação. Práticas que englobam as diferentes instâncias de uso da linguagem, sugerindo atividades de leitura, (tão esquecida na escola!); de produção de textos; de análise lingüística tornam-se o ponto de atuação do professor e do aluno, erigindo-se como lugar privilegiado das aprendizagens lingüísticas [...]. (FONSECA, 1997, p. 40)

Da mesma forma, também tematizando a importância da proposta de Geraldi e considerando, em especial, o "Projeto do Wanderley", foram publicados textos dos seguintes professores/pesquisadores: Freire (1990), Galan (1991), Fiad (1993), Ilari (1993), MayrinkSabinson (1993), Britto (1997), Batista (1998), Prado (1999), Mortatti (1999b, 2000), Pivovar (1999) e Sá (2004).

Paulo Freire (1990), no capítulo "O professor: um profissional para si”, publicado no livro Paulo Freire: trabalho, comentário, reflexão, organizado por Geraldi e Adriano Nogueira, ressalta a "revolução" provocada pela proposta geraldiana, a partir da "vinculação do enfoque lingüístico" com uma "transformação no ensino". Ele apostou, portanto, nessa 
"revolução" a partir da linguagem representada pela proposta de Geraldi para que houvesse uma transformação no ensino de língua portuguesa no Brasil.

A partir dos contatos que tenho tido, a partir desses estudos que temos levado adiante quero refletir com vocês uma questão: entre as revoluções que conheço, que li, nenhuma delas se empenhou com uma transformação que fosse tão radical como o próprio ato humano da fala. Pensando nisso que dizia o Wanderley, tratamos de evitar a interdição da produção de discurso nas classes populares. [...] A partir daí se teria caminhado no sentido de permitir que a linguagem fosse um alerta e um sinal contra outras possíveis interdições de um ser humano sobre outro ser humano. (FREIRE, 1990, p. 38)

Maria Raquel Aparecida Coelho Galan, por sua vez, na dissertação de mestrado $A$ construção cotidiana de uma proposta de ensino: as falas de professores e alunos de LP do oeste do Paraná, ressaltando o projeto desenvolvido por Geraldi e colaboradores no oeste do estado do Paraná entre os anos de 1984 e 1986, registra os dados de sua participação junto ao grupo. A dissertação foi apresentada pela autora ao Programa de Pós-Graduação em LetrasLinguística da Universidade Federal de Santa Catarina (UFSC), em 1991, sob a orientação de Maria Marta Furlanetto. Na conclusão de sua dissertação, Galan (1991) enfatiza que a sua análise contempla uma proposta em desenvolvimento e, portanto, "Há uma história que não pode ser desconsiderada. [...] não basta se fazer uma proposta e depois ficar esperando o resultado. É preciso que se a analise, que se a estude ao mesmo tempo [para que se possa] avançar no processo" (GALAN, 1991, p. 130). Sobre o que representou a proposta de Geraldi naquele momento, ela relata:

A proposta de Geraldi chegou até nós trazendo em seu bojo concepções de linguagem, língua, gramática e avaliação como as esboçadas anteriormente. Toma o texto, oral e escrito, como unidade básica para o ensino de língua: tanto os produzidos em sala de aula como os produzidos fora dela. Tem como objetivo oportunizar ao aluno o domínio da língua culta, nas modalidades oral e escrita, sem que isso signifique o desprestigiamento da variedade falada pelo mesmo. Isso se dará através de atividades significativas em que o professor deverá procurar fugir do artificialismo dos exercícios desenvolvidos em sala de aula. (GALAN, 1991, p. 14)

No periódico Cadernos de estudos lingüísticos: 15 anos de Cadernos (1993), n. 24, do qual Geraldi foi coordenador durante 11 anos, ele foi homenageado por seus colegas. Os treze textos que o integram apresentam por objetivo agradecer o trabalho do ex-coordenador. Nesse periódico, durante os 11 anos de sua circulação sob a responsabilidade de Geraldi, foram publicados também textos de Geraldi sobre questões relativas à linguagem em geral e ao ensino de língua portuguesa. 
Nesse periódico, Raquel Salek Fiad (1993), uma das colaboradoras na execução do "Projeto do Wanderley", no texto "Um estudo de variantes textuais e sua contribuição ao ensino de língua materna", homenageia o colega e também o trabalho por ele desenvolvido, apresentando, em nota de rodapé, as reflexões de que participaram juntos: “Com este estudo, homenageio o Wanderley, com quem, no trabalho conjunto nestes últimos dez anos, fui-me envolvendo com as questões de ensino e educação" (FIAD, 1993, p. 35).

Também Rodolfo Ilari (1993), professor e colega de Geraldi do IEL, relembra momentos divididos com ele, em nota de rodapé, no texto "Alguns problemas semânticos na análise dos adjetivos": "Sobre algumas perguntas que este texto enumera, comecei a refletir no final da década de 1970, quando eu era monitor, e o Wanderley Geraldi aluno, dos cursos de Lógica e Linguagem" (ILARI, 1993, p. 41).

Maria Laura T. Mayrink-Sabinson (1993), por sua vez, no texto "A produção escrita da criança e sua avaliação", também em nota de rodapé, assegura, referindo-se ao texto publicado:

Sua publicação, neste número de Cadernos de estudos lingüisticos, tem por objetivo homenagear a João Wanderley Geraldi também por tudo o que ele tem feito pela educação neste país.

Estou ciente e mantenho a ambigüidade do título. Na verdade, a avaliação que se faz da escrita da criança ultrapassa os limites da avaliação da escrita apenas, passando a ser avaliação da própria criança. Algo que Wanderley vem apontando há mais tempo que eu. (MAYRINK-SABINSON, 1993, p. 19)

Também tematizando a proposta de Geraldi, Luiz Percival de Leme Britto a analisa no capítulo "Sujeito da linguagem, sujeito de ensino", que integra seu livro A sombra do caos: ensino de língua $\mathrm{X}$ tradição gramatical, resultante da tese de mesmo título, defendida, em 1997, no IEL/UNICAMP, sob a orientação de Geraldi. Para Britto (1997), o pensamento de Geraldi sobre o ensino de língua se destaca pela centralidade atribuída ao "trabalho lingüístico". Comparando a proposta de Geraldi à de Franchi ${ }^{147}$, ele as considera muito diferentes da proposta tradicional anterior a elas para o ensino de língua, pela união que apresentam entre teoria e prática no ensino.

A força do pensamento de Franchi e Geraldi está no fato de eles não se limitarem a propor um novo método ou novos procedimentos. Ao contrário, elaboraram suas propostas para o ensino de português a partir do estabelecimento de uma concepção de linguagem e de construção de conhecimento bastante diferente da tradicional, centradas na historicidade do sujeito e da linguagem. (BRITTO, 1997, p. 154)

\footnotetext{
${ }^{147}$ Como já mencionado, Carlos Franchi foi orientador da tese de doutorado de Geraldi. A "proposta de Franchi" a que Britto se refere encontra-se, especialmente, no volume Criatividade e gramática, publicado pela CENP/SE/SP, a partir de 1987.
} 
Antonio Augusto G. Batista, por sua vez, na entrevista "Recuperando as práticas de interlocução na sala de aula", feita a Geraldi, a qual foi publicada em Presença Pedagógica, em 1998, ressalta a competência de seu ex-professor. Para Batista (1998), o pensamento de Geraldi também tem visibilidade: “[...] por seu discurso, por suas idéias, pela experiência de correr atrás do pensamento que vai rápido numa direção desconhecida, que nos desloca da experiência natural com o mundo e aponta para um mundo novo e diferente [...]." (BATISTA, 1998, p. 5). Batista também conclui que o "novo e o diferente" são as principais características do pensamento de Geraldi. Para ele, Geraldi

[...] vem exercendo um papel decisivo no campo educacional, especificamente na renovação que, dos anos 80 para cá, vem se dando no ensino de Português e em seu estudo. Sem dúvida, seu primeiro livro (a coletânea $O$ texto na sala de aula: leitura \& produção) é divisor de águas no modo de pensar e praticar o ensino de Português. Um de seus capítulos ("Unidades básicas do ensino de Português") teve suas idéias apropriadas, com maior ou menor felicidade pela maioria das propostas curriculares estaduais e municipais produzidas ao longo da década passada e no início desta, assim como pelos Parâmetros Curriculares Nacionais, do MEC. (BATISTA, 1998, p. 6)

Também Guilherme do Val Toledo Prado, orientado por Fiad em sua tese de doutorado, Documentos desemboscados: conflito entre o gênero do discurso e a concepção de linguagem nos documentos curriculares de ensino de língua portuguesa, apresentada ao Programa de Pós-Graduação em Linguística Aplicada do IEL/UNICAMP, em 1999, toma por objetos, para o desenvolvimento de sua pesquisa: um conjunto diversificado de documentos oficiais sobre o ensino de Língua Portuguesa ${ }^{148}$; o texto "Diversidade e ensino", de Raquel Salek Fiad; a tese de doutorado de Silva (1994) e a posição teórica de Geraldi sobre o ensino de língua portuguesa no Brasil, contida em "Subsídios metodológicos para o ensino de língua portuguesa: $5^{\mathrm{a}}$. a $8^{\mathrm{a}}$. séries" (1981), na coletânea $O$ texto na sala de aula e em Portos de passagem (1991). Prado (1999) afirma que uma nova concepção de linguagem, baseada nos pressupostos teóricos sócio-interacionistas está contida nos documentos oficiais das décadas de 1980 e 1990 analisados. No entanto, para ele, é perceptível o “[...] paradoxo entre uma

148 Prado (1999) toma os seguintes documentos para análise: RIO DE JANEIRO, Directoria de Instrucção Pública, "Programma de Linguagem". Imprensa Oficial, 1932.; SÃO PAULO, Secretaria de Estados dos Negócios da Educação, "Programa para o Ensino Primário Fundamental - $1^{\circ}$. e $2^{\circ}$. ano". Livraria Francisco Alves, 1949.; MINAS GERAIS, Serviço de Orientação e Fiscalização do Ensino, "Programa experimental para as classes preliminares". Edições Ensino Ltda., 1959.; MINAS GERAIS, Secretaria do Estado da Educação, "Programa de $1^{\circ}$. grau". Imprensa Oficial, 1965.; SÃO PAULO (Estado). Secretaria da Educação. CERHUPE (Centro de Recursos Humanos e Pesquisas Educacionais "Prof. Laerte Ramos de Carvalho"). Guias curriculares para o ensino de $1^{\circ}$. grau, coord. Delma Conceição Carchedi. 1 ${ }^{a}$.ed. São Paulo, SE/CERHUPE, 1975, 276 p.; SÃO PAULO. Secretaria de Estado da Educação - Coordenadoria de Estudos e Normas Pedagógicas. "Proposta Curricular para o Ensino de Língua Portuguesa para o $1^{\circ}$. grau”, 4. ed., Imprensa Oficial, 1991. 80 p. 
normatização/fixação/estabilidade do documento curricular, [...] e a instabilidade/indeterminação/mobilidade da concepção de linguagem fundada no diálogo" (p. 138). Segundo o autor, o pensamento de Geraldi foi utilizado na elaboração de vários programas curriculares e de práticas de ensino de Língua Portuguesa em escolas públicas de várias cidades do país:

[...] não há como negar a influência do pensamento de Geraldi em inúmeros programas curriculares e, também, arrisco dizer, influência em uma boa parte das práticas de ensino de língua portuguesa realizadas nas escolas públicas de várias cidades brasileiras. (PRADO, 1999, p. 20)

Considerando o pensamento de Geraldi sobre o ensino de língua portuguesa como uma “revolução conceitual”, Maria do Rosário Longo Mortatti tematiza a proposta sobre o ensino de língua portuguesa de seu ex-orientador no artigo "Uma proposta para o próximo milênio: o pensamento interacionista sobre alfabetização", publicado em Presença pedagógica, em 1999. Especificamente sobre a década de 1980 no Brasil, Mortatti (1999b) considera, no âmbito da alfabetização, dois pensamentos: o construtivista, baseado nos pressupostos teóricos advindos da psicogênese da língua escrita, de Emília Ferreiro e outros pesquisadores que a auxiliaram no desenvolvimento da pesquisa; e o interacionista, no âmbito do qual se destaca o linguista Geraldi. Nas palavras de Mortatti (1999b), a partir dessa concepção teórica interacionista, Geraldi privilegia a "interlocução como lugar de constituição tanto da linguagem quanto dos sujeitos", priorizando o texto como objeto de ensino. Sob esse aspecto, segundo a autora, o pensamento de Geraldi representou uma "revolução conceitual" no ensino de língua portuguesa, sendo "[...] atualmente o que de melhor seremos capazes de levar para o próximo milênio relativamente à alfabetização, porque é ainda a proposta mais consistente para se enfrentar [...]” (p. 27). Segundo a autora, apresenta-se, nos textos de Geraldi,

[...] o questionamento das bases teóricas tradicionalmente adjacentes às discussões sobre o ensino da língua, no Brasil, e a proposta de uma abordagem desse ensino do ponto de vista do interacionismo lingüístico, a partir das contribuições da Análise do Discurso, da Teoria da Enunciação e da Sociolingüística. (MORTATTI, 1999b, p. 22-23)

Também no livro Os sentidos da alfabetização (1876-1994), publicado em 2000, que resultou da tese de livre-docência de Mortatti (2000), especificamente no tópico "A ausência presente do discurso", que integra o capítulo "Alfabetização: construtivismo e desmetodização", a autora propõe uma reflexão sobre as tematizações de Geraldi a respeito do ensino de língua portuguesa no Brasil. Mortatti (2000), mais uma vez, refere-se à fundamentação teórica das reflexões de Geraldi, destacando as questões "por quê" e "para 
quê" se ensina língua, norteadoras da proposta geraldiana, e finaliza o texto mencionando que “[...] as tematizações de Geraldi parecem sintomaticamente ausentes da bibliografia e, por vezes, das próprias tematizações e normatizações sobre alfabetização, especialmente no caso paulista" (p. 279), o que, ao seu ver, interpreta-se “[...] como indicativa de uma outra paradoxal ausência, de fato: a do texto como objeto de ensino e aprendizagem no processo de alfabetização" (p. 279). Sobre a inclusão de seu pensamento na alfabetização, afirma que

Mesmo não tratando muitas vezes explicitamente da alfabetização e não sendo citadas diretamente nos textos oficiais ou acadêmicos que dela tratam, as tematizações de Geraldi podem ser consideradas emblemáticas em relação ao ensino da língua, nesse âmbito incluindo-se o ensino inicial da leitura e escrita e sua abordagem do ponto de vista do interacionismo lingüístico. (MORTATTI, 2000, p. 277)

Referindo-se ao trabalho de Geraldi, Altair Pivovar, orientado por Carlos Alberto Faraco, defendeu a dissertação de mestrado Leitura e escrita: a captura de um objeto de ensino, em 1999, apresentada ao curso de Pós-Graduação em Letras da UFPR. Em sua dissertação, ele se refere à análise do trabalho com textos na escola, com destaque para o trabalho de Geraldi sobre o ensino de língua portuguesa, afirmando que sua proposta vincula uma concepção de linguagem ao ensino, sem obter sucesso, já que “[...] o discurso científico tem-se mostrado incapaz de gerar práticas eficientes de ensino, e isso porque ele é hegemônico, isto é, não estabelece interlocução com o ensino" (PIVOVAR, 1999, p. 11). Ele conclui sua dissertação afirmando que a dificuldade de aprendizagem de leitura e escrita dos alunos na escola se refere à "assimilação de estratégias de diálogo diretamente com os textos escritos". Para ele,

O "rigor científico" acaba produzindo discursos que servem mais ao embate ideológico do que efetivamente ao ensino. Daí se repetirem as críticas, daí não se ter ido além das "questões prévias" (a necessidade de se estabelecer uma concepção de linguagem), daí se repetirem as constatações de fracasso. $[\ldots]$

A crença da lingüística é que descobrindo os mecanismos básicos da linguagem e explicando-os com base num raciocínio lógico, todos vão entender e sair por aí aplicando-os ao ensino. Esquecem que até esse "raciocínio lógico" é um artifício científico [...]

Falta, como já alertamos, à esfera da ciência estabelecer uma interlocução com o ensino. (PIVOVAR, 1999, p. 13-14)

Sobre a oportunidade de conhecer a proposta de Geraldi para o ensino de língua portuguesa em Portugal, Maria Helena de Araújo Sá, na apresentação do livro A aula como acontecimento, publicado em 2004, na Universidade de Aveiro (Aveiro/Portugal), menciona tê-lo conhecido inicialmente a partir da leitura dos livros: $O$ texto na sala de aula: leitura \& 
produção, Portos de passagem e Linguagem e ensino: exercícios de militância e divulgação. Sobre o curso semestral na Universidade de Aveiro, ministrado por Geraldi e do qual resultou o livro, Sá (2004) menciona que: “[...] foi um dos mais ricos e desafiantes da nossa vida acadêmica e relacional" (p. 5). Sá destaca, ainda, o que é fundamental na proposta de Geraldi, concordando com o que é proposto pelo autor: a mobilidade do pensamento a partir de uma nova concepção de linguagem. Por meio dessa apresentação de Sá (2004), é possível depreender a concepção em voga em Portugal quanto ao ensino da língua, no que diz respeito ao trabalho com a Gramática Tradicional em sala de aula. Nesse sentido, ela considera que, para os portugueses, a proposta de Geraldi talvez seja ainda uma novidade.

Desse período, permanecem no nosso horizonte, pelo seu significado e
perspectivas educativas que abrem, ideias e conceitos como o de "memória
de futuro", cunhado em Bakhtin, um autor de referência, de "capatazia
pedagógica", ou de "método indiciário". Permanecem também histórias de
palavras escritas pelas crianças como procedimentos metodológicos, como
aquele que, num seminário de pós-graduação, deu origem à designada "regra
Leonor", forjada por um dos participantes, a Leonor, a partir de um exemplo
em língua portuguesa, e progressivamente confrontada, no seu reduzido
poder descritivo, com as múltiplas possibilidades oferecidas pela língua, de
forma a evidenciar a fragilidade e arbitrariedade de toda e qualquer tentativa
de sistematicidade normativa e a ideia de que o conhecimento não se
constrói a partir da fixação, mas a partir do provisório. (SÁ, 2004, p. 5)

Especialmente sobre o sucesso da coletânea $O$ texto na sala de aula: leitura \& produção (1984), mais conhecida e divulgada entre os professores de língua portuguesa, tendo por objetivo atender aos propósitos do "Projeto do Wanderley", destacam-se as análises de: Marinho (2001), Paula (2004a), Rojo e Cordeiro (2004) e Rojo (2008).

Referindo-se à coletânea $O$ texto na sala de aula, Marildes Marinho, orientanda de doutorado de Possenti, defendeu a tese $A$ oficialização de novas concepções para o ensino de português no Brasil, em 2001, no IEL/UNICAMP. A partir da análise de diferentes propostas de base interacionista para o ensino de língua portuguesa em vários estados brasileiros, a autora concluiu que nelas estão incluídas as três áreas consideradas básicas para o ensino de língua portuguesa, a partir das proposições de Geraldi: leitura, produção e análise linguística de textos. Por meio de uma análise dos currículos estaduais anteriores aos Parâmetros Curriculares Nacionais (PCN), foi constatada pela autora "uma apropriação" dos pensamentos bakhtiniano e geraldiano nesses documentos, tendo por base uma concepção interacionista de linguagem. Sobre a proposta de Geraldi para o ensino de língua portuguesa, especialmente sobre a coletânea $O$ texto na sala de aula, Marinho (2001) afirma:

Breviário, bíblia, cartilha são termos que representam o papel atribuído à coletânea organizada por Geraldi (1984), por ter se transformado em leitura 
obrigatória e prazerosamente repetida, num exercício em busca de mudanças, o qual é batizado como "militância e divulgação" em seu último livro. Princípios indesejáveis e signo de uma postura discursiva para aqueles que desejavam mudanças no ensino da língua. (p. 46)

Em minha dissertação de mestrado ${ }^{149}$, desenvolvida sob a orientação de Maria do Rosário Longo Mortatti, O ensino de língua portuguesa, segundo João Wanderley Geraldi, apresentada ao Programa de Pós-Graduação em Educação da FFC, da Unesp-Marília, a partir de uma abordagem histórica, analisei a coletânea de artigos $O$ texto na sala de aula (Assoeste,1984; Ática, 1997 e 2005a), organizada por Geraldi. Nessa análise, enfatizei os cinco artigos em que Geraldi comparece como autor ou co-autor, e, para o desenvolvimento da pesquisa documental e bibliográfica, utilizei os procedimentos de localização, recuperação, reunião, seleção e ordenação da bibliografia de Geraldi e sobre sua obra e atuação profissional, assim como de bibliografia especializada sobre o ensino de língua portuguesa e sobre o interacionismo linguístico, além de ter realizado uma entrevista semi-estruturada com Geraldi. Dessa forma,

[...] foi possível constatar a base teórica interacionista do autor presente na coletânea analisada, $O$ texto na sala de aula, assim como caracterizar essa coletânea como síntese de uma "revolução conceitual" no ensino de língua portuguesa em nosso país. (PAULA, 2004a, p. 120)

Destacando a importância da coletânea $O$ texto na sala de aula: leitura \& produção e a questão do texto tido como a base do processo de ensino-aprendizagem, Roxane Rojo e Glaís Sales Cordeiro elaboraram, em 2004, a apresentação do livro Gêneros orais e escritos na escola, cuja publicação resultou de uma compilação de textos do suíço Bernard Schneuwly e do espanhol Joaquim Dolz sobre o tema, traduzidos por Rojo e Cordeiro. Mesmo não sendo abordada diretamente a coletânea nem o trabalho de Geraldi nos textos compilados, as autoras abordam a história do texto no Brasil, mencionando a proposta de Geraldi. Para elas, o texto deve ser compreendido como objeto de ensino, e não de uso, e, sob esse aspecto, criticam a proposta de Geraldi para o ensino de língua portuguesa, mesmo considerando a sua importância em um dado momento do ensino brasileiro, fundamental para a centralidade do texto como a base desse ensino. Segundo Rojo e Cordeiro (2004), a proposta de Schneuwly e Dolz $^{150}$ de utilização do texto para o ensino é mais apropriada que a de Geraldi, pois eles

\footnotetext{
${ }^{149}$ A referência completa de minha dissertação de mestrado se encontra no item "Referências", desta tese (PAULA, 2004a).

${ }^{150}$ A proposta de Schneuwly e Dolz para o ensino de língua materna se pauta na concepção de que a comunicação (oral ou escrita) deve ser "ensinada sistematicamente". A proposta está articulada em uma "[...] estratégia, válida tanto para a produção oral como para a escrita, chamada sequência didática, a saber, uma seqüência de módulos de ensino, organizados conjuntamente para melhorar uma determinada prática de linguagem. As seqüências didáticas instauram uma primeira relação entre um projeto de apropriação de uma
} 
tomam o texto como objeto, a partir do trabalho com os "gêneros textuais" autoras,

O texto na sala de aula, ou o texto como objeto de ensino ou como material sobre o qual se desdobra um ensino procedimental ("processual"), em leitura e compreensão de textos e em produção de textos, afirma-se juntamente com o deslocamento dos eixos de ensino-aprendizagem de língua materna: de um ensino normativo, que priorizava a análise da língua e a gramática, para um ensino procedimental, em que os usos da língua escrita, em leitura e redação, são também valorizados; preconiza-se, também, uma análise gramatical ligada a esses usos textuais: as atividades epilinguísticas. (ROJO, CORDEIRO, 2004, p. 8)

Comparativamente à proposta de Geraldi para o ensino da língua, a proposta de Schneuwly e Dolz se diferencia da geraldiana sob dois aspectos: Schneuwly e Dolz propõem a sistematização das atividades de linguagem, enquanto Geraldi propõe um trabalho de reflexão linguística; além disso, quanto aos gêneros textuais, Schneuwly e Dolz os "confrontam" com as atividades propostas por eles, as "sequências didáticas", enquanto para Geraldi, os gêneros textuais mantêm “[...] relações intrínsecas com outros gêneros” (2008e, p. 33), ou seja, ele considera que "Se eu desvinculo o tipo de texto do gênero discursivo, e, portanto, de outras possibilidades de entender como as organizações sociais criam para si seleções de tipos de textos, há um retorno ao ensino das formas sem conteúdos” (p. 33).

Destacando o trabalho realizado com o texto a partir da década de 1980, Rojo (2008), no capítulo de livro "O texto no ensino-aprendizagem de línguas hoje: desafios da contemporaneidade", também considera a importância da atuação de Geraldi para o ensino de língua portuguesa, com destaque para a apresentação do texto como a principal unidade de trabalho dos professores de língua portuguesa em sala de aula. Quanto à utilização do texto, Geraldi o caracteriza como objeto de práticas efetivas de leitura e de produção, mas a crítica de Rojo (2008) a Geraldi, com relação à utilização do texto, refere-se à sua não caracterização como objeto de ensino, e sim, de procedimento. O destaque de Geraldi quanto à utilização do texto também se deve, segundo Rojo (2008), ao “[...] questionamento e revisão das práticas de reprodução de textos modelares na redação/composição, em favor de práticas de efetiva produção de textos situados" (p. 11). Dessa forma, a autora novamente ressalta a contribuição de Geraldi para a atribuição da centralidade do texto como unidade de ensino, mas como prática de linguagem e os instrumentos que facilitam essa apropriação. Desse ponto de vista, elas buscam confrontar os alunos com práticas de linguagem historicamente construídas, os gêneros textuais, para lhes dar a possibilidade de reconstruí-las e delas se apropriarem" (SCHNEUWLY; DOLZ, 1994, p. 51, grifos dos autores) ${ }^{151}$ Sobre o trabalho com "gêneros textuais", nos PCNs, é citado o seguinte livro de Schneuwly, a partir do qual se considera que há o desenvolvimento do termo proposto por Bakhtin: SCHNEUWLY, Bernard. Genres et types de discours: considérations psychologiques et ontogenétiques. Les interacions lecture-écriture. Suíça: Peter Laug, 1993. 
“procedimento", e não como objeto de ensino, contrapondo, mais uma vez, à proposta de Geraldi para o ensino de língua portuguesa a de Schneuwly e Dolz para o ensino de língua materna, por entendê-las como sendo contrárias.

\begin{abstract}
Na virada pragmática, portanto, num processo conflituoso e dialético, o texto ganha estatuto de principal unidade de ensino na sala de aula. Mas não ainda de objeto de ensino. O texto literário, publicitário, de entretenimento e jornalístico passa a ser utilizado em sala de aula para suportar procedimentos de leitura e de (re)produção, descritos e divulgados nas pesquisas da psicologia cognitiva e do processamento: as estratégias de leitura e modelos de processamento em produção. Temporariamente, a disciplina de LP perde "conteúdo" e se torna procedimental. (ROJO, 2008, p. 11)
\end{abstract}

Por ocasião da publicação da $2^{\mathrm{a}}$. edição da coletânea $O$ texto na sala de aula, pela editora Ática, em 2005, os professores/pesquisadores Barzotto, Barbosa, Hessel, Possenti e Shirakura tiveram publicados cinco textos como orelhas na coletânea.

No primeiro texto publicado na $1^{\mathrm{a}}$. orelha da coletânea, Valdir Heitor Barzotto (2005) se refere ao trabalho de Geraldi com o ensino de língua portuguesa: "Com este conhecimento, aprendemos a perguntar aos fatos e aos textos a que eles vieram e descobrimos que se pode ir muito além" (BARZOTTO, 2005, $1^{\mathrm{a}}$. orelha).

Marinalva Vieira Barbosa (2005), professora da Universidade Federal do Triângulo Mineiro (UFTM), sobre a leitura de $O$ texto na sala de aula, no segundo texto publicado na $1^{\mathrm{a}}$. orelha, relata o seu envolvimento com ela antes mesmo de ter conhecido os autores dos artigos da coletânea. Além disso, ela evidencia a base teórica fundamental proposta na coletânea e na qual ela confia para a execução de seu trabalho, pois, "Antes de ter rostos, os autores foram "palavras"” (BARBOSA, 2005, 1'. orelha).

Rosa Hessel, professora da UFGRS (Porto Alegre/RS), no terceiro texto publicado na $1^{\text {a }}$. orelha, sobre a coletânea e a atuação de Geraldi, refere-se à dificuldade de se identificar quão valiosa foi a contribuição de Geraldi para o ensino de língua portuguesa no estado do Rio Grande do Sul, tal o seu comprometimento. "É difícil aquilatar a marca, os sinais do trabalho do Prof. Geraldi nos rumos do ensino [...]" (HESSEL, 2005, 1ª . orelha).

Sírio Possenti, referindo-se especialmente ao artigo "Unidades básicas do ensino de português", ressalta a importância do trabalho de Geraldi:

[...] quem já trabalhou tendo-o como base ou guia, ou mesmo quem só ouviu falar de resultados que as práticas por ele previstas produzem - sabe que está aí um projeto poderoso que poderia alterar significativamente o resultado do trabalho da escola, antes que outros aspectos sejam alterados ou mesmo se outros aspectos não forem alterados - sobretudo salários e horas de trabalho dos professores. (POSSENTI, 2005, $2^{\mathrm{a}}$. orelha) 
Para Norma Shirakura, professora da rede estadual de Campo Grande/MS, os artigos da coletânea ressignificaram as suas aulas de língua portuguesa: "Estes textos desbravaram caminhos jamais trilhados, apontando para nós o profundo significado que era dar aulas de português. Depois da leitura, ao voltar para a sala de aula, eu era outra: conseguia ser feliz" (SHIRAKURA, 2005, 2a . orelha).

Sobre a proposta de Geraldi, tematizada em Portos de passagem, foram publicados textos de: Franchi (1991), Fischer (1992) e Gonçalves (2008).

Franchi (1991) aponta o compromisso de Geraldi com o professor, ressaltando que seu ex-orientando é bem mais que linguista, é um "professor" que se preocupa com a prática do ensino, de forma madura e consciente. Para ele, Portos de passagem é a própria reflexão sobre a prática, a partir de teorias linguísticas que permitem o diálogo do ensino com a linguagem.

Comparativamente às ideias de Franchi (1991), sobre a natureza do teor expresso em Portos de passagem, Fischer (1992) também destaca a possibilidade de essa proposta ser posta em prática pela sua diferenciação: por visar à aventura e à produção de conhecimento tanto por parte de alunos quanto de professores, em reflexão contínua sobre a linguagem, à medida que Geraldi “invade o discurso pelo próprio discurso”. Fischer (1992), com relação à reflexão proposta pelos demais autores mencionados, conclui sua resenha enfatizando a novidade da proposta Geraldi ao ensino de língua portuguesa: "uma nova escuta e um novo olhar".

Especialmente sobre o livro Portos de passagem (1991), em resenha, Rosa Maria Bueno Fischer considera a sua diferenciação ao adentrar "o discurso pelo próprio discurso", centrada numa reflexão contínua sobre a linguagem.

[...] leio Portos de passagem e encontro, a cada parágrafo, a lembrança da voz e do gesto apaixonado de um professor em suas andanças pelo Brasil, a ensinar. Ensinar o quê? A ensinar, primeiro que "sobre muitas coisas o que sabemos é muito pouco". E que é possível uma outra proposta do ensino da língua portuguesa: o ensino como aventura e como produção de conhecimento, por alunos e professores. (FISCHER, 1992, p. 69)

Referindo-se também às ideias de Geraldi para o ensino de língua portuguesa, em especial às tematizadas em Portos de passagem, Rodrigo Tadeu Gonçalves defendeu a tese de doutorado Perpétua prisão órfica ou Ênio tinha três corações: o relativismo lingüístico e o aspecto criativo da linguagem, junto à UFPR, em 2008, sob a orientação de José Borges Neto. Para Gonçalves (2008), Geraldi retoma Franchi à medida que "[...] identifica o caráter constitutivo da linguagem com a sua noção de historicidade da linguagem” (p. 210). Nesse 
sentido, a proposição das três ações: com, sobre e da linguagem, só é possível a partir dessa concepção. Ele conclui que, "Se prevalecerem as ações $d a$ linguagem, sucumbiremos ao determinismo lingüístico total, e seremos efetivamente prisioneiros da nossa língua" (GONCALVES, 2008, p. 214, grifos meus). No tópico "Wanderley Geraldi, um notável Franchiano", como o título mesmo sugere, Gonçalves menciona a influência das ideias de Franchi no pensamento de Geraldi e, especialmente se referindo a Portos de passagem, ele afirma:

[...] um livro (a propósito prefaciado por Franchi) sobre linguagem e ensino de língua portuguesa, que parte de uma concepção franchiana de linguagem para o terreno dos estudos do discurso, fundamentado fortemente em Bakhtin e Foucault, entre outros. [...]

A concepção discursiva de linguagem apresenta-se em muitos pontos bastante próxima da concepção de linguagem como atividade constitutiva de Franchi [...].

Essa concepção de linguagem parte de pressupostos que se coadunam com o modo como a capacidade criativa emancipa o indivíduo e permite que ele molde a sua prisão lingüística privada. (GONÇALVES, 2008, p. 210)

Da bibliografia sobre Geraldi, no embate provocado por sua proposta "desestabilizadora de certezas", como ele mesmo a qualifica, a maioria dos professores/pesquisadores adere a ela, reconhecendo a sua importância para o ensino de língua portuguesa no Brasil.

Considero que se estabelece, a partir dela, um marco no ensino: antes e depois da proposta de Geraldi. E concordo com o que ele mesmo afirma em entrevista:

[...] um professor, hoje, pode continuar trabalhando bem tradicionalmente o ensino de língua, ao estilo "Pasquale Neto", ou coisa semelhante, mas ele já ouviu falar que "por aí não se chega a lugar algum". Hoje, mesmo que ele continue ensinando o que sempre se ensinou, fazendo o que sempre se fez, ele já sabe que por aí ele não vai chegar à formação de leitores e autores de textos. (GERALDI, 2004a, p. 4-5)

No entanto, em três desses textos sobre Geraldi, há divergência quanto às práticas que ele propõe: Pivovar (1999), no tocante ao fato de que a Linguística, apesar de pretender, não pôde estabelecer uma relação positiva com o ensino de língua portuguesa, já que os professores ainda desconhecem as influências dessa teoria em sala de aula; e Rojo e Cordeiro (2004) e Rojo (2008), por considerarem que o texto passou para o centro do processo de ensino de língua portuguesa de maneira errada, a partir da divulgação da proposta de Geraldi, já que, ao invés de ser caracterizado como objeto de ensino, foi tido, por Geraldi, como "possibilitador de procedimentos". 
Discordo da reflexão de Pivovar (1999) quanto ao fato de a proposta de Geraldi ser um discurso científico que não propõe relações com o ensino, considerando o fato de ela ter sido elaborada tendo o professor como interlocutor. Um exemplo disso é o fato de $O$ texto na sala de aula ter sido publicado para a utilização dos professores que participavam do "Projeto do Wanderley".

Quanto às proposições de Rojo e Cordeiro (2004) e Rojo (2008), concordo com elas quanto à incontestável importância da proposta de Geraldi para o ensino de língua portuguesa, como anteriormente mencionei. No entanto, quanto ao fato de a proposta de Geraldi ter possibilitado a utilização do texto como procedimento de ensino da língua ou não, mais importante que isso, ao meu ver, são as reflexões sobre a linguagem propostas por Geraldi a partir da utilização do texto.

Nesses embates, diálogos foram estabelecidos, tanto com seus professores, colegas de cursos e de projetos, nos quais atuavam em formação de professores, como com seus orientandos e alunos, e professores em formação. E foram esses diálogos que propiciaram críticas, sejam positivas ou negativas, porque conduziram os professores envolvidos no ensino de língua portuguesa a conheceram a sua proposta, já que a interlocução era estabelecida diretamente com eles.

A legislação de ensino que estava em vigor naquele momento, década de 1980, Lei 5692, de 11 de agosto de 1971, previa, dentre outros aspectos, "estudos adicionais", os quais correspondiam a um ano para os profissionais que possuíam Licenciatura Curta, para que atuassem no ensino de $2^{\circ}$. Grau (o atual Ensino Médio). Esses estudos adicionais poderiam ser realizados, segundo o Artigo 31, parágrafo único: “[...] em faculdades, centros, escolas, institutos e outros tipos de estabelecimentos criados ou adaptados para esse fim, com autorização e reconhecimento na forma da Lei”. Essa lei, portanto, possibilitava a formação dos professores em cursos e projetos, tal como o divulgado por Geraldi e seus colaboradores, na época.

A proposta de Geraldi foi reconhecida em âmbito nacional. Prova disso é sua vinculação às propostas curriculares e aos Parâmetros. Retomando o que afirma Batista (1998) e Prado (1999), concordo com os autores quanto ao fato de as propostas curriculares e os Parâmetros, com especial destaque para o último, terem se apropriado das ideias de Geraldi. O problema, como eles ressaltam, é a maneira como foram apresentados os Parâmetros, como um discurso oficial que foi imposto aos professores, contrariando a proposta de Geraldi sobre a construção e a reconstrução do pensamento na prática e sobre a mobilidade deste, considerando a constitutividade da linguagem e do sujeito. 
Também concordo com Galan (1991) quando afirma que a proposta geraldiana "lançou sementes", cujos resultados serão mais visíveis ao longo do tempo, e que, para que isso aconteça, são necessários estudos como este que aqui proponho, para melhor conhecê-la, analisá-la e compreendê-la no decorrer do tempo.

\section{CAPÍTULO 5 \\ CONCEPÇÕES TEÓRICAS \\ DO PENSAMENTO DE GERALDI}




\subsection{Textos citados por Geraldi}

A partir da localização, recuperação, reunião, seleção e ordenação de 224 referências de textos de Geraldi ${ }^{152}$, e após o manuseio desses textos, ordenei as referências dos textos que são citados por ele nos textos em que tematiza diretamente o ensino de língua portuguesa. Apresento as referências desses textos no instrumento de pesquisa Referências de textos mais citados por J. W. Geraldi em textos que tematizam o ensino de língua portuguesa: um instrumento de pesquisa ${ }^{153}$ (Apêndice B).

Dentre os textos de Geraldi sobre o ensino de língua portuguesa e que apresentam referências de textos citados por ele, destacam-se: livros (como autor, coordenador, organizador): 4; capítulos de livros (como autor): 6; artigos em periódicos: (como autor/coautor): 9; e textos em anais de eventos (como autor): 2, totalizando 21 textos.

Dos livros de Geraldi que apresentam referências de textos citados, destacam-se: Portos de passagem (1991) e Linguagem e ensino: exercícios de militância e divulgação (1996), como autor; e O texto na sala de aula: leitura \& produção (1984) e O texto na sala de aula (1997), como organizador.

Dentre os capítulos de livros que apresentam referências de textos citados, destacamse: "Linguagem e ação" (1991), "O professor como leitor do texto do aluno (1991)", “A leitura em momento de crise social" (1995), "Da sala de aula à construção externa da aula" (1999), "A presença do texto na sala de aula" (2006) e "Leitura: uma oferta de contrapalavras" (2007).

\footnotetext{
${ }^{152}$ Como anteriormente informado, no instrumento de pesquisa Bibliografia de e sobre J. W. Geraldi: um instrumento de pesquisa (PAULA, 2009a), no Apêndice A, encontram-se todas as referências de textos de e sobre Geraldi localizados até o momento.

${ }^{153}$ No instrumento de pesquisa Referências de textos citados por J. W. Geraldi em seus textos sobre o ensino de língua portuguesa (PAULA, 2009b), no Apêndice B, encontram-se todas as referências de textos citados por Geraldi em seus textos sobre o ensino de língua portuguesa.
} 
Quanto aos artigos em periódicos que apresentam referências de textos citados, destacam-se: "Possíveis alternativas para o ensino da língua portuguesa” (1982), “Aprende-se a escrever escrevendo" (1985), "Prática de produção de textos na escola" (1986), "Aprende-se a escrever escrevendo" (1987), "A leitura na sala de aula: as muitas faces de um leitor" (1988), "Texto: um problema para o exercício da capatazia” (1989), “Abordagem sóciointeracionista no ensino, leitura e escrita" (1996), como autor; e "Considerações sobre a utilização de um paradigma indiciário na análise de episódios de refacção textual” (1995) e "As aventuras do conhecer: da transmissão à interlocução" (2002), como co-autor.

E, dentre os textos em anais, destacam-se: "De como produzir milagres ou o professor pega um boizinho, rifa e compra livros" (1986) e "Sobre a constituição dos objetos de ensino em língua materna" (2000), como autor.

Após a análise das referências de textos citados por Geraldi, constatei quais autores são recorrentemente citados por ele em seus textos.

Dentre os autores citados por Geraldi, apenas alguns deles apresentaram ideias que foram de fato constitutivas de sua proposta para o ensino de língua portuguesa no Brasil, já que não concordou com todos eles.

No Quadro 12, destaco, por ordem de ocorrência, os autores cujos textos são mais citados por Geraldi em seus textos sobre o ensino de língua portuguesa, assim como a filiação institucional/país de origem de cada um deles.

Ressalto que considerei apenas os textos citados mais de cinco vezes nos textos de Geraldi, tendo em vista a grande quantidade de autores citados em número menor do que esse, muitos deles com apenas uma ocorrência. 
Quadro 12 - Autores mais citados por Geraldi em textos que tematizam diretamente o ensino de língua portuguesa, por ordem de ocorrência e filiação institucional/país de origem

\begin{tabular}{|c|c|c|c|}
\hline $\begin{array}{c}\text { QUAN- } \\
\text { TIDAD } \\
\text { E DE } \\
\text { AUTO- } \\
\text { RES }\end{array}$ & $\begin{array}{l}\text { AUTORES MAIS } \\
\text { CITADOS }\end{array}$ & $\begin{array}{c}\text { FILIAÇÃO } \\
\text { INSTITUCIONAL/PAÍS DE } \\
\text { ORIGEM }\end{array}$ & $\begin{array}{c}\text { OCORRE } \\
\text { N- } \\
\text { CIA }\end{array}$ \\
\hline 1 & GERALDI, João Wanderley & IEL/UNICAMP (Campinas/Brasil) & 21 \\
\hline 2 & BAKHTIN, Mikhail & Universidade Estatal da Mordóvia (Saransk/Rússia) & 19 \\
\hline 3 & OSAKABE, Haquira & IEL/UNICAMP (Campinas/Brasil) & 12 \\
\hline 4 & LAJOLO, Marisa & $\begin{array}{c}\text { IEL/UNICAMP (Campinas/Brasil)/ } \\
\text { Mackenzie (São Paulo/Brasil) }\end{array}$ & 11 \\
\hline 5 & BENVENISTE, Émile & EHESS (Paris/França)/Collège de France & 9 \\
\hline 6 & POSSENTI, Sírio & IEL/UNICAMP (Campinas/Brasil) & 8 \\
\hline 7 & FREIRE, Paulo & FE/UNICAMP (Campinas/Brasil) & 7 \\
\hline 8 & GNERRE, Maurizzio & IEL/UNICAMP (Campinas/Brasil) & 7 \\
\hline 9 & ORLANDI, Eni L. P. & IEL/UNICAMP (Campinas/Brasil) & 7 \\
\hline 10 & SOARES, Magda Becker & UFMG/(Belo Horizonte/Brasil) & 7 \\
\hline 11 & FOUCAULT, Michel & Collège de France (Paris/França) & 6 \\
\hline 12 & FRANCHI, Carlos & IEL/UNICAMP (Campinas/Brasil) & 6 \\
\hline 13 & DUCROT, Oswald & EHESS (Paris/França) & 5 \\
\hline 14 & ILARI, Rodolfo & IEL/UNICAMP (Campinas/Brasil) & 5 \\
\hline 15 & ZILBERMAN, Regina & UFRGS (Porto Alegre/Brasil) & 5 \\
\hline 16 & PÊCHEUX, Michel & $\begin{array}{l}\text { Centre National de la Recherche Scientifique } \\
\text { (Paris/França) }\end{array}$ & 5 \\
\hline
\end{tabular}

Fonte: Referências de textos mais citados por J. W. Geraldi em textos que tematizam o ensino de língua portuguesa: um instrumento de pesquisa (PAULA, 2009b) (Apêndice B)

Dentre os 16 autores cujos textos são mais citados por Geraldi, destacam-se, por ordem de ocorrência, os textos de: J. W. Geraldi, Mikhail Bakhtin, Haquira Osakabe, Marisa Lajolo, Émile Benveniste, Sírio Possenti, Paulo Freire, Maurizzio Gnerre, Eni Orlandi, Magda Soares, Michel Foucault, Carlos Franchi, Oswald Ducrot, Rodolfo Ilari, Regina Zilberman e Michel Pêcheux.

Para melhor identificar esses autores, considero cinco categorias: "J. W. Geraldi", "autores estrangeiros", "orientador da tese de doutorado", "unicampianos" e "professores de outras instituições brasileiras", como apresento abaixo, no quadro 13. 
Quadro 13 - Autores mais citados por Geraldi, por categorias de identificação

\begin{tabular}{|c|c|c|}
\hline $\begin{array}{l}\text { OCORRÊN- } \\
\text { CIA }\end{array}$ & IDENTIFICAÇÃO & $\begin{array}{l}\text { AUTORES MAIS CITADOS POR } \\
\text { GERALDI }\end{array}$ \\
\hline 1 & J.W. GERALDL & GERALDL. João Wanderlev \\
\hline 2 & \multirow{5}{*}{$\begin{array}{c}\text { AUTORES } \\
\text { ESTRANGEIROS }\end{array}$} & BAKHTIN Mikhail \\
\hline 3 & & BENVENISTE. Emile \\
\hline 4 & & FOUCAULT Michel \\
\hline 5 & & DUCROT Oswald \\
\hline 6 & & PECHEUX. Michel \\
\hline 7 & ORIENTADOR DA TESE & FRANCHI, Carlos \\
\hline 8 & \multirow[t]{7}{*}{ UNICAMPIANOS } & POSSENTI Sírio \\
\hline 9 & & FREIRE. Paulo \\
\hline 10 & & OSAKABE. Haquira \\
\hline 11 & & LAJOLO Marisa \\
\hline 12 & & GNERRE. Maurizzio \\
\hline 13 & & ORLANDI. Eni L. Pulcinelli \\
\hline 14 & & ILARI. Rodolfo \\
\hline 15 & \multirow{2}{*}{$\begin{array}{c}\text { PROFESSORES DE } \\
\text { OUTRAS } \\
\text { INSTITUIÇÕES } \\
\end{array}$} & SOARES, Magda Becker \\
\hline 16 & & ZILBERMAN, Regina \\
\hline
\end{tabular}

Fonte: Referências de textos mais citados por J. W. Geraldi em textos que tematizam o ensino de língua portuguesa: um instrumento de pesquisa (PAULA, 2009b) (Apêndice B)

Dentre os 16 autores mais citados por Geraldi, na primeira categoria de autores mais recorrentes em seus textos, aparece “J. W. Geraldi”. Na segunda categoria, "autores estrangeiros", aparecem Mikhail Bakhtin, Émile Benveniste, Michel Foucault, Oswald Ducrot e Michel Pêcheux; o primeiro de origem russa, e os demais, de origem francesa. Na terceira categoria, "orientador da tese de doutorado", estão as referências de textos de Carlos Franchi. Na quarta categoria, "unicampianos”, estão: Haquira Osakabe, Marisa Lajolo, Sírio Possenti, Paulo Freire, Maurizzio Gnerre, Eni Pulcinelli Orlandi e Rodolfo Ilari. E, na quinta categoria, "professores de outras instituições brasileiras", aparecem as autoras: Magda Soares e Regina Zilberman, respectivamente das instituições: UFMG e UFRGS.

Quanto ao texto de Geraldi mais citado em seus textos sobre o ensino de língua portuguesa se trata de Portos de passagem (1991). Em segundo lugar, em número de ocorrência, é mais recorrentemente citado o periódico "Subsídios metodológicos para o 
ensino de língua portuguesa: $5^{\mathrm{a}}$. a $8^{\mathrm{a}}$. séries" (1981), e, em terceiro, a coletânea $O$ texto $n a$ sala de aula: leitura \& produção (1984).

A incidência de referências de seus próprios textos em outros textos seus representa a continuidade do trabalho de Geraldi ao longo dos anos e a relação entre esses trabalhos, principalmente no que diz respeito às pesquisas referentes ao ensino de língua portuguesa e à importância desse tema, apresentado e discutido pelo autor, tendo em vista a quantidade de textos publicados, como anteriormente mencionado.

Nesses textos, destacam-se as concepções de: "linguagem", "sujeito" e "discurso/texto", que constituem a sua proposta, assim como a característica de historicidade da linguagem, que ele passa a abordar, sobretudo em Portos de passagem, e as três práticas para o ensino de língua portuguesa: leitura, produção e análise linguística de textos.

Dentre os autores estrangeiros mais citados por Geraldi em seus textos, destaca-se Mikhail Bakhtin ${ }^{154}$, cujo livro mais citado é Marxismo e filosofia da linguagem, publicado pela Hucitec (São Paulo) e cuja primeira edição é de 1981. Esse livro foi citado por Geraldi, pela primeira vez, no texto "A leitura na sala de aula: as muitas faces de um leitor", publicado em 1988, no periódico Idéias (São Paulo).

Em Marxismo e filosofia da linguagem, pautado em concepções da Teoria da Enunciação, a qual privilegia, por sua vez, segundo Charaudeau e Maingueneau (2004, p. 193), “a relação entre a língua e o mundo", Bakhtin (2002) se contrapõe principalmente às concepções saussureanas sobre objetivismo abstrato, para quem, segundo Bakhtin (2002, p. 82), “A língua é um sistema estável, imutável, de formas lingüísticas submetidas a uma norma fornecida $[\ldots] "$.

Contrariamente às concepções linguísticas saussureanas, Bakhtin afirma, em especial, a movimentação característica da língua. Para ele, a palavra está sempre carregada de significado, e apresenta, sobretudo, caráter social. Sob esse ponto de vista, a língua é constituída na e pela interação verbal, por meio de enunciações historicamente pensadas. E, nesse âmbito, o sujeito também se constitui na interação com o outro.

No momento inicial de elaboração da proposta de Geraldi para o ensino de língua portuguesa, quando foi publicado "Subsídios...", talvez as ideias de Bakhtin ainda não

${ }^{154}$ Sobre Mikhail Bakhtin, Clark e Holquist (2004) argumentam que o pensador russo e sua obra se apresentam sob o "signo da pluralidade", para os quais propõem a divisão dos estudos bakhtinianos nos seguintes períodos: uma fase filosófica (entre 1918 e 1924); um diálogo com movimentos intelectuais, tais como o freudismo, o marxismo soviético, o formalismo, a linguística e a fisiologia (entre 1925 e 1929); uma poética histórica na evolução do romance (durante os anos de 1930); e a metafísica por meio da perspectiva da teoria social e da filosofia da linguagem (nos anos 1960 e 1970). 
estivessem sendo contempladas por Geraldi, haja vista as referências indicadas por ele nesse periódico, dentre as quais não há menção aos textos de Bakhtin. Somente na coletânea $O$ texto na sala de aula (1984), há a seguinte epígrafe de Bakhtin no texto "Concepções de linguagem e ensino de português":

$\mathrm{Na}$ realidade, toda palavra comporta duas faces. Ela é determinada tanto pelo fato de que procede de alguém, como pelo fato de que se dirige para alguém. Ela constitui justamente o produto da interação do locutor e do ouvinte. Toda palavra serve de expressão a um em relação a outro. (BAKHTIN apud GERALDI, 1984, p. 41)

Nesse sentido, apesar de sua proposta estar baseada em concepções da Linguistica da Enunciação, talvez fosse um Bakhtin lido ainda por outros autores que Geraldi conhecesse, como exponho no tópico seguinte, a partir de reflexões de Brait (2003). Considerando os três livros de Geraldi que me propus analisar nesta tese, a partir de Portos de passagem é que as concepções bakhtinianas são mais evidenciadas por Geraldi, constituindo a sua proposta, principalmente no que se refere à concepção de sujeito, interação verbal, social e historicidade.

Do francês Émile Benveniste ${ }^{155}$, os livros mais citados por Geraldi são Problemas de lingüistica geral I e Problemas de lingüística geral II. O primeiro foi publicado inicialmente pela Cia. Editora Nacional (São Paulo) e pela Editora da USP (São Paulo), em 1976, e, posteriormente, desde 1995, pela Pontes (Campinas) e pela Editora da UNICAMP (Campinas); o segundo foi publicado pela Pontes, em 1989. Desses livros, destacam-se dois capítulos citados por Geraldi em seus textos: "Da subjetividade na linguagem", de Problemas de lingüistica geral I; e "O aparelho formal da enunciação", de Problemas de lingüística geral II.

Ressalto que Geraldi traduziu o texto "O antônimo e o pronome em francês moderno e a forma e o sentido na linguagem" (1989), de Émile Benveniste, como já mencionado, publicado em Problemas de lingüistica geral II.

No capítulo "Da subjetividade na linguagem", a principal ideia benvenistiana que contribuiu para a proposta de Geraldi refere-se ao fato de a linguagem ser compreendida como complementar à natureza humana, na caracterização do sujeito. E, quanto à enunciação, em "O aparelho formal da enunciação", Benveniste (1989a) distingue entre enunciado e enunciação, caracterizando o primeiro como um ato individual, e o segundo, como o que estabelece relação entre a língua e o discurso, numa "relação discursiva entre 'eu e tu"”.

${ }^{155}$ Émile Benveniste, linguista estruturalista francês, atuou na EHESS e no Collège de France, como professor de linguística até 1969, quando se aposentou. Benveniste estudou as línguas indo-europeias e a questão da subjetividade linguística, conduzindo a questão do sujeito para o centro das discussões linguísticas. 
A partir de Benveniste, essas concepções, embasadas na Teoria da Enunciação, foram de extrema importância para o trabalho de Geraldi, sobretudo em "Subsídios", pela focalização do sujeito. No entanto, por não considerar a historicidade, essas concepções tanto deixaram de ser utilizadas por Geraldi no decorrer da divulgação de sua proposta, como foram também criticadas em Linguagem e ensino, como abordo no Capítulo 6, no que se refere a esse aspecto.

Quanto ao livro de Michel Foucault mais recorrente nos textos de Geraldi, destaca-se A ordem do discurso, primeiramente publicado em Cadernos da FIDENE (Ijuí), em 1973, em uma tradução de Sírio Possenti e revisão de Dinarte Belatto e José Crippa. Esse livro foi publicado posteriormente pelas Edições Loyola (São Paulo), em 1996, traduzido por Laura Fraga de Almeida Sampaio. Geraldi cita também em seus textos esse livro em francês, L'ordre du discours, o qual foi publicado em 1971, pela editora Gallimard (Paris/França).

Nesse livro sobre discurso, Foucault menciona as "relações de poder" que "movimentam" as instâncias discursivas como práticas sociais definidoras de seus sujeitos e das relações de que eles participam. A expressão "formação discursiva", pela qual seu pensamento ficou conhecido, define os enunciados que participam das mesmas regras, as quais são determinadas historicamente. A Análise do Discurso de linha francesa ganhou, em Foucault, um importante adepto, que contribuiu para as concepções da Análise do Discurso, contrapondo-se também, assim como Bakhtin, às concepções advindas da linguística estruturalista.

Foram de fundamental importância para a proposta de Geraldi, especialmente em Portos de passagem, as ideias de Foucault sobre as "relações de poder", para que houvesse reflexão sobre os "mecanismos de controle" que engendram as práticas em sala de aula. No entanto, Geraldi critica a ideia foucaultiana de que o sujeito participa de uma formação discursiva, sendo assujeitado pelas condições que a produzem, pois, para ele, o sujeito também contribui para a sua formação à medida que produz.

Quanto ao texto mais citado do linguista francês Oswald Ducrot, trata-se do livro $O$ dizer e o dito, publicado pela Pontes (Campinas), em 1987, cujo revisor técnico de tradução é Eduardo Roberto Junqueira Guimarães. Nesse livro, encontra-se publicado o texto "As leis de discurso" (1987), de Oswald Ducrot, cuja tradução é de Geraldi.

Ducrot se fundamenta em uma perspectiva ligada à Semântica Argumentativa, a qual, segundo Trask (2006), estuda o significado a partir da argumentação. Seus estudos estão voltados para uma concepção linguística de base estruturalista, que privilegia a definição dos 
objetos, os quais são caracterizados por meio da sua relação com outros, pautando-se na descrição linguística da língua.

Com relação às ideias linguísticas de Ducrot, Geraldi discorda do fato de as atividades linguísticas serem apenas descritas como verdades insolúveis. Para ele, não há atividades préestabelecidas em linguagem, mas reflexões conjuntas entre professor e aluno, que, por sua vez, podem, juntos, construir reflexões sobre a língua.

Com relação aos textos de Michel Pêcheux ${ }^{156}$ citados por Geraldi, por número de ocorrências, destaca-se o livro $O$ discurso: estrutura ou acontecimento (1990), publicado pela editora Pontes (Campinas).

Pêcheux contrapõe as concepções teóricas da Análise do Discurso às concepções advindas do Estruturalismo, as quais, segundo ele, propõem uma análise da língua, dividindoa em estruturas, numa análise descritiva. Para Pêcheux, dentre outras teorias humanas, a Análise do Discurso possibilita fazer considerações a respeito das diferentes relações no jogo interpretativo. E, sob esse aspecto, todo enunciado merece ser interpretado. Pêcheux critica a concepção de Foucault, segundo a qual a "formação discursiva" provoca o "assujeitamento".

A principal contribuição das ideias de Pêcheux à proposta de Geraldi se refere justamente ao fato de ser possível, a partir das contribuições da Análise do Discurso, pensar nas relações de produção, na historicidade e no movimento produzido nas relações discursivas de que participa o sujeito, provocando a sua diferenciação a depender dessas relações, considerando, a partir de então, um novo nível de análise, o "discurso", e não mais a palavra ou a frase, o qual abordo no Capítulo 6.

Com relação aos textos de Carlos Franchi, orientador da tese de doutorado de Geraldi, os textos mais citados por Geraldi são: o artigo "Linguagem: atividade constitutiva", texto que resultou da tese de doutorado de Franchi, intitulada Hipóteses para uma teoria funcional da linguagem, publicada primeiramente no periódico Almanaque (São Paulo), em 1977, e, posteriormente, em anais do GEL, em 2002; e o texto Criatividade e gramática, publicado em Trabalhos em lingüística aplicada, em 1987, e pela CENP/Secretaria do Estado de São Paulo, em 1988.

É importante destacar a homenagem de Geraldi a Franchi na entrevista "Trajetória com ética e genialidade" (2001), publicada no Jornal da UNICAMP. Em contrapartida, como informado no Capítulo 2, o livro Portos de passagem (1991), de Geraldi, foi também “homenageado" com belíssimo prefácio de Franchi.

${ }^{156} \mathrm{O}$ linguista francês Michel Pêcheux é reconhecido como um dos principais fundadores da Escola Francesa de Análise do Discurso. A partir de 1966, Pêcheux integrou o Departamento de Psicologia do C.N.R.S., em Paris/França. 
Carlos Franchi (1977), em concordância com as concepções teóricas de Michel Lahud, para quem há uma ciência da linguagem, e não uma ciência descritiva das línguas, fundamenta-se em Chomsky, que, por sua vez, pauta-se em um mecanismo mais complexo de descrição, tomando a sintaxe como eixo central. Essa perspectiva teórica de Franchi se contrapõe às seguintes concepções de linguagem: a saussureana — por privilegiar apenas a concepção de língua; a bloomfieldiana — segundo a qual a linguagem é apenas teoria; a estruturalista americana - cujo objeto se confunde com os procedimentos; a de Martinet e de Katz - que tem a linguagem como código, reduzida ao descritivismo. Chomsky, por sua vez, fundamenta-se em Humboldt, que, apesar de concordar com a sistematicidade dos processos linguísticos superficiais, juntamente com os estruturalistas americanos, distancia-se deles com relação à concepção de sintaxe. A partir dessas concepções linguísticas, para Franchi, a linguagem não é apenas uma "ferramenta social", mas a "construção do pensamento" em um processo criador, com caráter histórico, aberto e criativo. $\mathrm{Na}$ visão franchiana, a linguagem é dinâmica.

Franchi (1988) também critica a redação, que, na escola, não é proposta como prática de produção de textos, mencionando a necessidade de "construir os esquemas e não apenas reproduzi-los", por meio do pensamento e da linguagem, que são "formas de ação", pois o falante, a partir da língua, também a explica. Dessa forma, o professor, em sala de aula, na visão linguística franchiana, deve conduzir os alunos à reflexão sobre a linguagem. Para ele,

[...] somente se aprende a gramática, quando relacionada a uma vivência rica da língua materna, quando construída pelo aluno como resultado de seu próprio modo de operar com as expressões e sobre as expressões, quando os fatos da língua são fatos de um trabalho efetivo e não exemplos descolados da vida. (FRANCHI, 1988, p. 24)

Pensar nas ideias de Franchi sobre a linguagem é pensar na dinamicidade e na criatividade tanto da linguagem, quanto do sujeito e do pensamento, imbricadas numa relação de constituição a partir da historicidade. Nesse sentido, as contribuições de Franchi para o pensamento de Geraldi sobre o ensino de língua portuguesa foram fundamentais, pois lhe deram a oportunidade de pensar nessa relação constitutiva da linguagem e do sujeito e de eleger, ao mesmo tempo, o texto como objeto de ensino, aspecto pelo qual diferem as propostas do orientador e do orientando, a partir, tão somente, da indicação das três práticas para o trabalho com o texto, por Geraldi.

Quanto aos colegas da UNICAMP, os textos de Sírio Possenti são os mais recorrentes, em especial o livro Por que (não) ensinar gramática na escola, publicado pelas editoras ALB 
e Mercado de Letras, e cuja primeira edição data de 1996. Possenti tem três textos publicados em parceria com Geraldi: o texto "A interlocução no debate político" (1988); a entrevista "O efeito das palavras" (1982); e a apresentação ao livro de Iracema Gabler, Nair Gurgel e Tânia Rocha Parmigiani, Análise do discurso: uma leitura e três enfoques (2001). Além de ter também um texto publicado na $1^{\mathrm{a}}$. edição da coletânea $O$ texto na sala de aula: leitura \& produção, e dois textos na edição publicada pela Ática.

Esse autor também elaborou um texto sobre Geraldi, o qual foi publicado na segunda orelha da coletânea $O$ texto na sala de aula (2005a), como informei anteriormente.

Possenti, dentre outras, discorre sobre as seguintes questões, para ele, antagônicas: “ensinar língua" e "ensinar gramática”, como abordagens distintas. As reflexões propostas por esse autor visavam a: que o ensino de língua portuguesa não ocorresse a partir de conteúdos prontos, mas que houvesse um trabalho de "construção de conhecimentos" dos alunos, e que o ensino estivesse vinculado à aprendizagem.

Nesse sentido, as ideias de Geraldi apresentam concordância com as de Possenti, no que se refere à reflexão sobre a linguagem com o aluno, quando lhe é oportunizada pelo professor condições em sala de aula de pensar sobre as atividades linguísticas propostas.

Quanto aos textos de Paulo Freire ${ }^{157}$ mais citados nos de Geraldi, destaca-se o livro $A$ importância do ato de ler, publicado em 1982, pela Cortez (São Paulo). Após o retorno de Paulo Freire do exílio ${ }^{158}$, Geraldi participou com ele de algumas ações, tais como as dos encontros denominados "Colóquios Interdisciplinares em Educação", durante o $1^{\circ}$. primeiro semestre de 1989, na UNICAMP, os quais foram transcritos no livro coordenado por Geraldi e Adriano Nogueira, Paulo Freire: trabalho, comentário, reflexão (1990). Em outros textos seus, desde a década de 1990 até os dias atuais, Geraldi também retoma o trabalho de Freire: os outros dois livros publicados, Paulo Freire: una reflexión sobre la educación, administración y política en el município de São Paulo, Brasil (1994), traduzido para a língua espanhola, em parceria com Adriano Nogueira; e, em parceria com Luiza Cortesão, Rosa Nunes, Abreu Freire, Rui Trindade e João Eustáquio Romão, o livro Diálogos através de Paulo Freire (2004); o texto "Paulo Freire: narrador e pensador" (1997), publicado como capítulo de livro e artigo em periódico; "Paulo Freire e Mikhail Bakhtin: o encontro que não houve" (2003), publicado como capítulo de livro, em dois livros diferentes; e o texto "A linguagem em Paulo Freire" (2005), como artigo em periódico. Paulo Freire também se

\footnotetext{
${ }^{157}$ Após o exílio, Paulo Freire se destacou por sua atuação junto à Prefeitura de São Paulo, de 1989 a 1991, quando foi Secretário de Educação. Na UNICAMP, foi professor titular da FE/UNICAMP, durante 11 anos, de 1980 a 1991.

${ }^{158}$ Informações disponíveis em $<$ http://www.paulofreire.org $>$.
} 
referiu ao trabalho realizado por Geraldi, no texto "O professor: um profissional para si", como já mencionado no capítulo 4.

Abordando a prática de leitura, Paulo Freire se refere à natureza e à importância do ato da leitura como processo educativo e, sobretudo, político. Sob essa concepção, para ele, “a leitura do mundo precede a leitura da palavra". Ele também aborda a leitura "artificial", que privilegia a quantidade de textos lidos, e não a sua qualidade, com aprofundamentos necessários no texto. Nesse sentido, para Freire, as palavras devem atribuir sentido a quem as lê e, para tanto, deve-se partir do "universo vocabular" de quem as aprende.

Quanto ao privilégio da qualidade à quantidade, as ideias de Geraldi sobre leitura diferem das de Freire quanto a um aspecto: para Geraldi, a quantidade de livros lidos pode gerar a qualidade, por ampliar o conhecimento do aluno. Mas no que se refere ao aspecto político e educativo, há concordância do pensamento de Geraldi com o de Freire, pois, para ambos, a linguagem, o ensino e a concepção política estão imbricados na formação do sujeito. Pensando assim, um bom professor é o que apresenta definida uma concepção política, ou seja, aquele que sabe "para quê e por quê" está ensinando.

Quanto aos textos de Haquira Osakabe, seu colega do IEL/UNICAMP, o texto mais citado por Geraldi é o capítulo "Considerações em torno do acesso ao mundo da escrita", publicado no livro organizado por Regina Zilberman, A leitura em crise na escola, pela editora Mercado Aberto (Porto Alegre/RS), em 1982. Geraldi, em parceria com Osakabe, elaborou dois textos: um publicado como texto em anais "A interlocução no debate político" (1988), e outro, como entrevista, “O efeito das palavras” (1982).

Para Osakabe (1982), há distinção entre língua oral e língua escrita. A língua escrita, segundo o autor, que é a mais veiculada no âmbito escolar, deve propor movimento, e não, em suas palavras, "adestramento" dos alunos. Geraldi concorda com o exposto por Osakabe por considerar que o movimento é o que define as relações de ensino.

Dos textos de Marisa Lajolo ${ }^{159}$, o livro $O$ que é literatura, publicado pela Brasiliense (São Paulo), em 1982, é o mais recorrente.

A questão central a que Lajolo se refere diz respeito a quais textos podem ser considerados literatura e também sobre a qualidade dos textos que os alunos leem. A literatura é, assim, para a autora, o que se pode criar no plano da ficção e que não existiria, se não fosse criado ficcionalmente. Geraldi também se pauta na qualidade da leitura dos alunos, no entanto, como mencionei acima, para ele, a quantidade pode gerar essa qualidade.

\footnotetext{
${ }^{159}$ Segundo dados do currículo do Sistema de Currículos Lattes, Marisa Philbert Lajolo atua atualmente como professora da Universidade Presbiteriana Mackenzie e mantém vínculo como professora colaboradora voluntária na UNICAMP, tendo por áreas de interesse: história da leitura, literatura infantil e/ou juvenil e Monteiro Lobato.
} 
De Maurizzio Gnerre, que trabalhou no Brasil e foi colega de Geraldi na UNICAMP, os textos mais citados por Geraldi são: o livro Linguagem, escrita e poder, publicado pela Martins Fontes (São Paulo), em 1985; e o texto "Linguagem e poder", publicado em Subsídios à proposta curricular de Língua Portuguesa para o $2^{\circ}$. grau: variação lingüística e ensino da língua materna, pela Secretaria de Educação do Estado de São Paulo, em 1978.

Nas concepções de Gnerre, Geraldi se fundamenta no que se refere às variedades linguísticas e o "acesso ao poder", considerando o bloqueio que a sociedade impõe quanto ao acesso à linguagem, quando privilegia determinadas variedades linguísticas em detrimento de outras.

Essa concepção de Gnerre, tendo por base a Sociolinguística, está relacionada também a uma concepção política, constitutiva do pensamento de Geraldi, que reflete sobre qual trabalho com a linguagem é realizado na escola, excluindo ou não todos os diferentes falantes que estão em seu meio.

De Eni Pulcinelli Orlandi ${ }^{160}$, colega de Geraldi na UNICAMP, os textos mais recorrentemente citados em textos dele foram os artigos: "A produção da leitura e suas condições" e "As histórias das leituras", ambos publicados no periódico Leitura: teoria \& prática, respectivamente em 1983 e em 1984. O texto de Geraldi “Tópico-comentário e orientação argumentativa" (1981) foi publicado como capítulo no livro Sobre a estruturação do discurso, organizado por Eni Pulcinelli Orlandi, pelo IEL/UNICAMP.

A partir de concepções teóricas advindas da Análise do Discurso, Orlandi (1983, 1984) considera o texto a partir das relações que o produziram, mas sem levar em conta a participação do sujeito. Além disso, ela também destaca o fato de toda leitura ter a sua história. Geraldi discorda da primeira concepção de Orlandi, por considerar que o sujeito também contribui, e muito, para as relações possíveis de serem estabelecidas em um texto. Dessa forma, apesar de algumas publicações em parceria com Orlandi, em um determinado momento, principalmente em Linguagem e ensino, Geraldi critica a posição teórica referente à Análise do Discurso adotada por ela.

De Rodolfo Ilari, colega de Geraldi da UNICAMP, o texto mais recorrentemente citado nos textos de Geraldi é o livro A lingüística e o ensino da língua portuguesa, publicado pela Martins Fontes, em 1985, sobre o qual Geraldi elaborou uma resenha, também publicada em 1985. Em parceria com Rodolfo Ilari, Geraldi escreveu: o livro Semântica (1985); o capítulo de livro "Argumentative operators and dialogue", publicado em inglês, e o mesmo

${ }^{160}$ Tomando por base informações do currículo do Sistema de Currículos Lattes, consultado em 20 de novembro de 2009, Eni Orlandi é atualmente professora colaboradora no IEL/UNICAMP, atuando nas áreas de análise de discurso, linguística, epistemologia da linguagem e jornalismo científico. 
texto em português, "Operadores de argumentação e diálogo", publicado como artigo em periódico. Geraldi também elaborou o prefácio "Sagacidade, argúcia e lupa" ao livro Introdução à Semântica: brincando com a gramática, de Ilari.

Rodolfo Ilari, como já abordado no Capítulo 3, também elaborou o artigo "Alguns problemas semânticos na análise dos adjetivos" (1993), em homenagem a Geraldi, o qual foi publicado no periódico Cadernos de estudos lingüisticos, número 24.

Ilari teve significativa participação no que diz respeito à contribuição da Linguística para o ensino de língua portuguesa. Segundo o autor, a partir de concepções estruturalistas, chomskyanas e de grupos da Sociolinguística, Psicolinguística e Pragmática, o professor passou a analisar melhor a língua, e, sob esse aspecto, a linguística contribuiu para esse ensino.

Geraldi talvez tenha pensado sobre muitas dessas questões do "encontro entre linguagem e ensino" com Ilari, no que há concordância de seus pensamentos, pois Geraldi também menciona a "desestabilização de certezas" que a linguística ocasionou, especialmente na década de 1980 no Brasil. No entanto, a atuação de Geraldi se destaca não só pela elaboração de uma proposta para o ensino de língua portuguesa, a partir de contribuições de concepções linguísticas, em especial do interacionismo, mas também pela divulgação dessa sua proposta.

Com relação aos textos de Magda Soares citados, professora emérita da UFMG, o mais recorrente é o livro Linguagem e escola: uma perspectiva social, publicado pela Ática, em 1985.

Para Soares são de extrema importância as relações entre linguagem, escola e sociedade, visando a uma escola com condições de atingir uma transformação social. Nesse sentido, para a autora, ensinar linguagem é ensinar uma concepção política também. Sob esse aspecto, os pensamentos de Geraldi e Soares apresentam absoluta concordância.

De Regina Zilberman ${ }^{161}$, o livro mais recorrentemente citado nos textos de Geraldi é $A$ leitura em crise na escola: as alternativas do professor, organizado por Zilberman e publicado pela Mercado Aberto (Porto Alegre), em 1982. Nesse livro, são publicados dez textos de professores que, preocupados com a leitura e a escola, apresentam a leitura como uma solução para a democratização da escola. As questões discutidas nos textos versam sobre a questão da leitura, a partir de visão teórica, sugestões práticas e problemas da escrita, com suas

${ }^{161}$ Segundo informações do currículo do Sistema de Currículos Lattes de Regina Zilberman, consultado em 10 de dezembro de 2009, ela atua como professora colaboradora do Instituto de Letras da UFRGS, e como professora-pesquisadora na Faculdade Porto-Alegrense. Foi professora titular da PUC/RS. 
dificuldades e possibilidades. Zilberman (1982) expõe a crise, existente na época da publicação do livro, tanto da escola quanto do professor. O livro foi elaborado visando a

[...] um novo perímetro para a leitura e o texto literário em sala de aula, sugerindo um relacionamento mais participante para o professor e para o aluno, de modo a tornar autenticamente democrático o processo por que passa a escola brasileira no nosso tempo (ZILBERMAN, 1982, p. 8).

Também para Geraldi a leitura participa dessa democratização na escola, à medida que "democratiza" também o sujeito, dando-lhe autonomia para ser ele mesmo e, sobretudo, para pensar.

As ideias linguísticas divulgadas pelo pensamento dos autores citados nos textos de Geraldi estão vinculadas às concepções advindas da: Linguística Descritiva, Teoria da Enunciação, Gramática Gerativa, Sociolinguística e Análise do Discurso, teorias linguísticas em voga no momento de formação acadêmica de Geraldi, sobre as quais proponho reflexões no tópico a seguir.

Dessa forma, posso afirmar que, no embate entre as diferentes concepções sobre o ensino de língua portuguesa, o pensamento de Geraldi se constituiu, sobretudo, a partir das ideias de seu orientador de doutorado, Carlos Franchi, das ideias do russo Mikhail Bakhtin sobre linguagem e das ideias linguísticas de origem francesa.

Vinculadas a essas ideias, em seu pensamento também estão contidas as questões discutidas pela "geração de lingüistas brasileiros daquele momento", que pensavam sobre a linguagem em nosso país: unicampianos e alguns professores de outras instituições brasileiras.

Enfim, todas essas ideias contribuíram para a constituição do pensamento de Geraldi sobre o ensino de língua portuguesa, pois, assim como Orlandi (1984), considero que, a leitura de um leitor possui uma história e "O conjunto de leituras feitas configuram, em parte, a compreensibilidade de cada leitor específico" (p. 8).

\subsection{Concepções linguísticas}

No final da década de 1970 e início da década de 1980, quando, no ensino de língua portuguesa no Brasil, apresentavam-se problemas com relação à repetência e evasão, no âmbito linguístico, diversas concepções eram contrapostas à concepção advinda da Linguística Descritiva, em voga até aquele momento. 
Segundo Trask (2006), a Linguística Descritiva teve influência no Estruturalismo linguístico, que, por sua vez, muito contribuiu para a constituição da Linguística como ciência, desde o início do século XX. Ferdinand de Saussure é seu principal precursor, o qual

[...] defendeu a idéia de que se faz mais justiça às línguas considerando-as como sistemas estruturados, no interior dos quais cada elemento se define primordialmente pela maneira como está relacionado aos outros elementos. Segundo essa perspectiva, que recebeu o nome de estruturalismo, o objeto primário de estudo é o sistema, não os elementos particulares presentes no sistema. (TRASK, 2006, p. 100, grifos do autor)

Essa concepção linguística de cunho estruturalista encontrou, nos Estados Unidos da América, adeptos como Edward Sapir e Leonard Bloomfield.

Com relação às ideias bloomfieldianas, segundo Trask (2006), nas décadas de 1940 e 1950, elas

[...] foram levadas ao extremo por seus sucessores, no desenvolvimento do estruturalismo americano, uma abordagem da descrição lingüística que foi vigorosa, mas excessivamente dogmática, e atribuiu uma importância extrema à distribuição. (TRASK, 2006, p. 100, grifos do autor)

A partir dessa concepção linguística, a Linguística foi enfatizada, como afirma Leroy (1971), na “[...] esperança de ver nossa ciência reintegrar-se, graças ao uso de um método lógico-matemático, no seio das ciências exatas”. E complementa:

[...] enquanto no século passado [século XIX], o lingüista se via colocado diante de uma poeira de fatos, hoje se encontra diante de uma estrutura, pois cumpre dizê-lo de novo, estrutura é a idéia-força da Lingüística atual. Ontem, a Lingüística era obra de erudição; hoje, tornou-se uma ciência. (LEROY, 1971, p. 219)

Sobre o Estruturalismo linguístico, Ducrot (1971) argumenta que: “[...] tem de apurar o conceito de estrutura a fim de que remeta a outra coisa que não seja à simples idéia de organização, já presente nas gramáticas mais tradicionais” (p. 26). Sob esse aspecto, ser um linguista que se apóia no Estruturalismo, segundo Ducrot, é “[...] definir os objetos deste domínio uns em relação aos outros, ignorando voluntariamente aquilo que, na sua natureza individual, se defina apenas em relação aos objetos de outro domínio" (DUCROT, 1987, p. $67)$.

A partir de 1950, o estruturalismo saussureano passou a ser questionado pelos precursores da Gramática Gerativa, que teve Noam Chomsky como seu principal precursor. Os gerativistas, também chamados transformacionalistas, consideram, sobretudo, a "língua 
como produção". Inicia-se, a partir daí, uma tendência mais explicativa em Linguística. Assim como cita Benveniste (1989b), um gerativista “[...] parte da fala como produto" (p. 18).

Sobre a Gramática Gerativa, para Trask (2006), ela se caracteriza como: “A gramática de uma determinada língua que é capaz de definir todas as sentenças gramaticais dessa língua e somente essas.” (p. 127). Para ele, uma das principais características da Gramática Gerativa é a "recursividade", segundo a qual uma "[...] mesma regra possa aplicar-se sucessivas vezes na construção de uma mesma sentença" (p. 127). Uma outra característica fundamental dessa Gramática é a "capacidade gerativa”, que, por sua vez, indica que: “[...] quanto maior o número de tipos de fatos diferentes de que a gramática pode tratar com sucesso, maior a capacidade gerativa dessa gramática" (p. 127).

Ao mesmo tempo em que se pensa na estrutura e/ou na "produção" da língua, as quais são denominadas Linguística Imanente, e que constitui a tendência formalista, as concepções linguísticas pautadas no contexto de produção da linguagem e nos aspectos históricos, vão aos poucos ganhando amplitude, modificando, assim, o nível de análise.

A respeito do estudo da língua vinculado ao social, são fundamentais, dentre outras, as contribuições da Sociolinguística. Sobre os estudos sociolinguísticos, para Trask (2006), eles tiveram origem em Saussure, no início do século XX, mas somente ganharam a devida importância nos anos 1950.

Dentre outros nomes de destaque na Sociolinguística, é de fundamental importância William Labov, que, “[...] nos anos 1960, começou uma série de investigações sobre variação lingüística - investigações que revolucionaram nossa compreensão de como os falantes utilizam sua língua [...]” (TRASK, 2006, p. 277). A partir daí, a Sociolinguística se destacou como a ciência do estudo sobre a variação na língua.

No Brasil, abordando estudos baseados nessa concepção, destaca-se Gnerre (1978), para quem a linguagem é mais que um "meio de informação". A função primordial da linguagem é indicar a "posição que o falante ocupa na sociedade em que vive". Segundo ele, todo sujeito, quando se expressa verbalmente, faz uso de determinados critérios: “[...] a) quando pode falar e quando não pode, b) que tipo de conteúdos referenciais lhe são consentidos, c) que tipo de variedade lingüística é oportuno que seja usada" (p. 61), ou seja, para ele, as variedades linguísticas existentes em toda a sociedade determinam a de maior prestígio no meio social em que as variedades circulam. 
Naquele momento, destacam-se também as concepções teóricas que percebem não só a linguagem, mas também a sua significação ${ }^{162}$. Dentre elas, tem relevo a Pragmática, a qual, segundo Orlandi (1999b), “[...] se inclui, ao lado do estudo da relação entre os signos (sintaxe) e do estudo das relações entre os signos e o mundo (semântica), o estudo das relações entre os signos e seus usuários" (p. 55, grifos do autor).

Partindo de uma das vertentes da Pragmática ${ }^{163}$ e abordando especialmente a interlocução, destaca-se a Teoria da Enunciação. Especificamente sobre o termo “enunciação", segundo Charaudeau e Maingueneau (2004), ele teve origem na filosofia e foi usado no âmbito da linguística a partir de 1930, por Charles Bally.

A enunciação constitui o pivô da relação entre a língua e o mundo: por um lado, permite representar fatos no enunciado, mas, por outro, constitui por si mesma um fato, um acontecimento único definido no tempo e no espaço. (CHARAUDEAU; MAINGUENEAU, 2004, p. 193)

Sob essa concepção, tem destaque o pensamento de Benveniste desde a segunda metade da década de 1960. Para ele, a Teoria da Enunciação é “[...] este colocar em funcionamento a língua por um ato individual de utilização" (BENVENISTE, 1989b, p. 82). O autor distingue entre enunciação - "ato de produzir um enunciado" -, e enunciado - "texto produzido", como me referi anteriormente neste mesmo capítulo. Na enunciação, para esse autor, a língua une locutor e interlocutor em um "processo de significação".

Como forma de discurso, a enunciação coloca duas "figuras" igualmente necessárias, uma, origem, a outra, fim da enunciação. É a estrutura do diálogo. Duas figuras na posição de parceiros são alternativamente protagonistas da enunciação. (p. 87)

No entanto, Benveniste considera o sujeito como produtor da enunciação, individualizando, assim, a partir de sua concepção, o processo. Esse autor não considera o contexto histórico em que essa enunciação acontece.

Contrariamente a essa concepção de Benveniste sobre o contexto em que se inserem as enunciações, Bakhtin, considerando pioneiramente as questões referentes à enunciação e abordando questões filosóficas sobre a linguagem, publicou o livro Marxismo e filosofia da linguagem, em 1929-1930, em Leningrado/Rússia, o qual teve a primeira edição no Brasil

\footnotetext{
${ }^{162}$ Com relação às diferentes áreas da Linguística, Orlandi (1999) assim as classifica: “[...] a fonologia (estudo das unidades sonoras); a sintaxe (estudo da estrutura das frases) e a morfologia (estudo da forma das palavras) que, juntas, constituem a gramática; e a semântica (estudo dos significados)" (p. 22).

${ }_{163}$ Segundo Orlandi (1999b), a Pragmática possui três vertentes: a lógica, "[...] em que a relação usuário/linguagem só aparece na medida em que ela é necessária para se determinar a verdade ou falsidade do que é dito" (p. 56); a behaviorista, em que "[...] essa relação linguagem/usuário é considerada levando-se em conta o hábito do usuário em utilizar o signo." (p. 56); e a de interlocução, em que se pensa "[...] o usuário em sua relação de interlocução com outro usuário, em uma situação de comunicação." (p. 56)
} 
somente em 1979, mais de uma década após os brasileiros terem tido conhecimento dos estudos de Benveniste. Segundo Brait (2003), somente a partir da década de 1980 os estudos de Bakhtin se revelam importantes na área da Linguística, apesar de ter "[...] antecessores desde a segunda metade da década de 60, como é o caso de Benveniste, para citar somente um" (p. 22).

Para Brait (2003), Marxismo e filosofia da linguagem "[...] aparece como uma forma de incorporar aos estudos lingüísticos uma concepção de linguagem, diferente da lingüística da imanência, na medida em que incluía a história e o sujeito" (p. 21). Para a autora, em um primeiro momento, as concepções bakhtinianas eram mais estudadas pelos literatos que pelos linguistas.

Sobre a língua, a fundamental concepção bakhtiniana se refere à sua capacidade de evolução ao longo do tempo, no que se distingue de Benveniste, que não aborda essa questão.

Assim, na prática viva da língua, a consciência lingüística do locutor e do receptor nada tem a ver com um sistema abstrato de formas normativas, mas apenas com a linguagem no sentido de conjunto dos contextos possíveis de uso de cada forma particular. Para o falante nativo, a palavra não se apresenta como um item de dicionário, mas como parte das mais diversas enunciações dos locutores $\mathrm{A}, \mathrm{B}$ ou $\mathrm{C}$ de sua comunidade e das múltiplas enunciações de sua própria prática lingüística. (BAKHTIN, 2002, p. 95)

Segundo Bakhtin, a língua e o contexto em que foi utilizada se unem em uma mesma significação. E, por isso, a “[...] palavra está sempre carregada de um conteúdo ou de um sentido ideológico ou vivencial” (p. 95). Dessa forma, a Teoria da Enunciação, para Bakhtin, propõe a interação entre locutor e interlocutor em um determinado lugar social, a partir da enunciação pela qual se interligam, constituindo-se o social como fator determinante da enunciação. Sobre esse aspecto, Roman Jakobson (2002), em prefácio a Marxismo e filosofia da linguagem, menciona que as ideias contidas no livro antecipam as concepções sociolinguísticas, a partir do momento em que ele considera a linguagem em âmbito social.

Assim como a Sociolinguística e a Teoria da Enunciação, também se contrapondo às análises meramente descritivas ou explicativas da língua, e abordando especificamente o social, destaca-se na França, nos anos 60 e 70 do século XX, a Análise do Discurso, que teve Michel Pêcheux como principal precursor. Referindo-se especialmente à Escola Francesa de Análise do Discurso, Charaudeau e Maingueneau (2004) afirmam ser ela resultante da "[...] convergência de correntes recentes e da renovação da prática de estudos muito antigos de textos (retóricos, filológicos ou hermenêuticos)" (p. 43), unindo texto e contexto e expressando contradições ao Estruturalismo de Saussure, especialmente à distinção entre langue e parole. 
Tomando o discurso como objeto de estudo, Pêcheux interliga a história e a linguagem. E, assim como cita Orlandi (1990), o autor " [...] aceita seu desafio entrecruzando três caminhos: o do acontecimento, o da estrutura e o da tensão entre descrição e interpretação na Análise de Discurso" (p. 9). A Análise do Discurso se caracteriza como a ciência que analisa o texto produzido e o entorno, portanto, o discurso, ou, nas palavras de Pêcheux (1990), "acontecimento" e "estrutura".

Também o filósofo Michel Foucault realizou estudos que contribuíram para a Análise do Discurso, a partir, dentre outras questões, do estabelecimento de relações entre enunciados. Dentre os conceitos abordados por Foucault, destaca-se o de "formação discursiva":

\begin{abstract}
No caso em que se puder descrever, entre um certo número de enunciados, semelhante sistema de dispersão, e no caso em que entre os objetos, os tipos de enunciação, os conceitos, as escolhas temáticas, se puder definir uma regularidade (uma ordem, correlações, posições e funcionamentos, transformações), diremos, por convenção, que se trata de uma formação discursiva. (FOUCAULT, 2000, p. 43)
\end{abstract}

No final da década de 1970 e no início da década de 1980, estavam em voga em Linguística no Brasil as concepções advindas da Linguística Descritiva, da Gramática Gerativa, da Sociolinguística, da Teoria da Enunciação e da Análise do Discurso, as quais participavam de uma "formação discursiva" no âmbito da linguística.

No momento de sua formação, quando novas concepções linguísticas estavam sendo discutidas no interior do IEL/UNICAMP, Geraldi participava dessas reflexões, e a constituição de seu pensamento aconteceu em meio aos embates entre essas concepções, inicialmente em instituições de seu estado de origem, e, posteriormente, no IEL/UNICAMP.

Seus primeiros textos, como já mencionado no Capítulo 3, abordam as questões descritivas da linguagem, tendo por fundamentação teórica a Linguística Descritiva. No entanto, para abordar o ensino de língua portuguesa, Geraldi se apoia, teoricamente, sobretudo, em concepções advindas da Gramática Gerativa, da Sociolinguística, da Teoria da Enunciação e da Análise do Discurso.

Em seu pensamento, são perceptíveis esses embates teóricos, como “choques", já que o conhecimento não acontece de forma retilínea, mas a partir de descontinuidades. Dessa forma, a partir do que se estuda, do que se conhece, novas concepções vão se constituindo.

Essas descontinuidades são perceptíveis e se definem aos olhos do leitor, especialmente a partir dos textos citados por Geraldi, que se apresentam, ora de forma mais recorrente, ora deixando de ser citados. Essa descontinuidade pode ser constatada a partir da análise da trajetória de publicação de seus textos. 
Assim como afirma Geraldi (2004a), os estudantes da pós-graduação estavam lendo, naquela época, na área da linguística, o que "estava no ar". No entanto, nesse sentido, o seu diferencial foi pensar do interior da linguística o ensino de língua portuguesa, tendo escolhido o professor por seu interlocutor. Do interior da universidade, ele pensou em cursos para o professor, por considerar a necessidade dessa ação em conjunto com o professor no espaço da sala de aula, o que lhe permitiu pensar a linguística vinculada ao ensino de língua portuguesa.

Para pensar esse ensino, portanto, Geraldi partiu das leituras dos textos de Ducrot, Benveniste, Bakhtin, Foucault, Pêcheux, Franchi e Gnerre, e também dos textos de Osakabe, Lajolo, Possenti, Freire, Orlandi, Soares, Ilari e Zilberman.

A partir dos embates teóricos na área da Linguística, entre estruturalistas, gerativistas, sociolinguistas, linguistas pautados na enunciação e analistas do discurso, os "choques" foram ocorrendo, solidificando os conceitos-chave de sua proposta. Perdura em seus textos a discussão sobre "linguagem", "sujeito" e "discurso/texto", conceitos que serão por mim priorizados no Capítulo 6 desta tese.

Assim, comparativamente, nos três livros abordados nesta tese: $O$ texto na sala de aula: leitura \& produção (1984), Portos de passagem (1991) e Linguagem e ensino (1996), os embates teóricos advindos dessas concepções linguísticas apresentadas vão ganhando importância ao longo do tempo, definindo-se teoricamente, a partir de lutas travadas em meio a inúmeras teorias que se vão apresentando.

Aproveitando o pensamento de Kuhn (1982) ${ }^{164}$ sobre a ideia de “crise", é possível compreender que o pensamento geraldiano se constituiu na Linguística, contribuindo para o ensino de língua portuguesa, no momento em que uma "crise" se instaurava nesse ensino e no qual eram necessários outros paradigmas para que houvesse um novo sentido: "O significado das crises consiste exatamente no fato de que indicam que é chegada a ocasião para renovar os instrumentos" (p. 105).

A astronomia ptolomaica estava numa situação escandalosa, antes dos trabalhos de Copérnico. As contribuições de Galileu ao estudo do movimento estão estreitamente relacionadas com as dificuldades descobertas na teoria aristotélica pelos críticos escolásticos. A nova teoria de Newton sobre a luz e a cor originou-se da descoberta de que nenhuma das teorias pré-paradigmáticas existentes explicava o comprimento do espectro. A teoria ondulatória que substituiu a newtoniana foi anunciada em meio a uma preocupação cada vez maior com as anomalias presentes na relação entre a teoria de Newton e os efeitos de polarização e refração. [...] A emergência de novas teorias é geralmente precedida por um período de insegurança

\footnotetext{
${ }^{164}$ Thomas Kuhn, no livro $A$ estrutura das revoluções cientificas, propõe reflexões sobre a evolução da ciência, argumentando que um novo passo no conhecimento científico implica rupturas em relação a concepções anteriores na busca de um novo paradigma para que se resolva a "crise" estabelecida em um determinado domínio de conhecimento.
} 
profissional pronunciada, pois exige a destruição em larga escala de paradigmas e grandes alterações nos problemas e técnicas da ciência normal. (p. 94-95)

Nesse sentido, segundo Kuhn (1982), quando necessárias para a sociedade, há "revoluções científicas". Usando seu termo, é possível afirmar que o pensamento de Geraldi sobre o ensino de língua portuguesa, ainda atual nos dias de hoje, participou/participa de uma "revolução científica", na medida em que propôs/propõe um "deslocamento" das ideias linguísticas para o ensino de língua portuguesa.

Dessa forma, em um momento em que ocorria a busca por transformações políticosociais em nosso país, "olhares diferenciados" eram lançados também à linguagem, a fim de se buscar nela respostas a diferentes áreas, perscrutando, nas palavras de Benjamin (1994), "a faculdade de intercambiar experiências".

Com relação à abordagem da linguagem como resposta a várias questões, Kristeva (1969) menciona o olhar diretamente voltado ao sujeito, ocasionado por essa perspectiva:

Assim, o predomínio dos estudos lingüísticos e, mais ainda, a diversidade babiloniana das doutrinas lingüísticas - essa diversidade que foi baptizada com o nome de "crise" — indicam que a sociedade e a ideologia modernas atravessam uma fase de autocrítica. O seu fermento terá sido esse objecto sempre desconhecido - a linguagem. (KRISTEVA, 1969, p. 375)

A linguagem, a partir de Humboldt, passou a ser pensada como atividade, concepção essa contemplada nos estudos de Franchi $(1977,1988)$, já mencionados anteriormente, e dos quais o pensamento de Geraldi também se constituiu para contemplar suas preocupações sobre a linguagem e o ensino.

Quanto ao lugar de Geraldi como autor, considero, assim como menciona Foucault (2006), que "Um nome de autor não é, portanto, um nome próprio exactamente como os outros" (p. 44), pois o autor “[...] constitui o momento forte da individualização na história das idéias, dos conhecimentos, das literaturas, na história da filosofia também, e na das ciências" (p. 32), mesmo estando diretamente relacionado às diferentes condições de produção.

Dessa forma, Foucault considera que "Na escrita, não se trata da manifestação ou da exaltação do gesto de escrever, nem da fixação de um sujeito numa linguagem; é uma questão de abertura de um espaço onde o sujeito de escrita está sempre a desaparecer" (p. 35), representando um problema a individualidade do autor, em suas palavras. Para Foucault, é preciso localizar o "[...] espaço deixado vazio pelo desaparecimento do autor, seguir de perto 
a repartição das lacunas e das fissuras e perscrutar os espaços, as funções livres que esse desaparecimento deixa a descoberto" (p. 41). Nesse sentido,

[...] um nome próprio não tem uma significação pura e simples; quando se descobre que Rimbaud não escreveu La Chasse Spirituelle, não se pode pretender que esse nome próprio ou esse nome de autor tenha mudado de sentido. O nome próprio e o nome de autor encontram-se situados entre os pólos da descrição e da designação; têm seguramente alguma ligação com o que nomeiam, mas nem totalmente à maneira da designação, nem totalmente à maneira da descrição: ligação específica. No entanto - e daqui derivam as dificuldades particulares do nome de autor - a ligação do nome próprio com o indivíduo nomeado e a ligação do nome de autor com o que nomeia, não são isomórficas e não funcionam da mesma maneira. (FOUCAULT, 2006, p. 42-43)

Sob essa perspectiva,

[...] o nome de autor serve para caracterizar um certo modo de ser do discurso: para um discurso, ter um nome de autor, o facto de poder dizer 'isto foi escrito por fulano', ou 'tal indivíduo é o autor', indica que esse discurso não é um discurso quotidiano, indiferente, um discurso flutuante e passageiro, imediatamente consumível, mas que se trata de um discurso que deve ser recebido de certa maneira e que deve, numa determinada cultura, receber um certo estatuto. (FOUCAULT, 2006, p. 45)

A propósito, o que Foucault caracteriza como "função autor”, “[...] é, assim, característica do modo de existência, de circulação e de funcionamento de alguns discursos no interior de uma sociedade" (p. 46). A "função autor" é formada de maneira complexa, não representando apenas a atribuição de um discurso a um indivíduo. "O autor - ou o que tentei descrever como a função autor - é com certeza apenas uma das especificações possíveis da função sujeito" (p. 70).

Com Foucault, considero que o autor focaliza em seu texto muito do que vivencia e que, portanto, as vivências por que ele passa o constituem. No entanto, isso não significa o seu "assujeitamento".

Para Foucault, não há inexistência do autor. Sobre essa questão, ele menciona: “[...] não disse que o autor não existia; não disse e admiro-me que o meu discurso se tivesse prestado a semelhante contra-senso" (p. 80). Para ele, “[...] o autor deve apagar-se ou ser apagado em proveito das formas próprias aos discursos. Entendido isto, a questão que me coloquei foi esta: o que é que esta regra do desaparecimento do escritor ou do autor permite descobrir? Permite descobrir o jogo da função autor" (p. 80-81). E ainda: "Eu não disse que reduzia o autor a uma função, mas que analisava a função no interior da qual qualquer coisa 
como um autor podia existir. Não fiz aqui a análise do sujeito, fiz a análise do autor" (FOUCAULT, 2006, p. 83).

Dessa forma, para Foucault, a função autor caracteriza os sujeitos que discursam a partir de uma "formação discursiva", representando apenas uma das especificações possíveis nessa "formação discursiva".

A partir da concepção de Foucault sobre "formação discursiva", considero que o pensamento de Geraldi tenha participado de uma "formação discursiva" sobre o ensino de língua portuguesa no Brasil. No entanto, participando de uma "revolução conceitual" nesse ensino, a qual permitiu a união entre linguagem e ensino, tomo outro termo foucaultiano, "fundadores de discursividade", para afirmar que o pensamento de Geraldi auxiliou na fundação de um discurso, à medida que permitiu e ainda permite que outros discursos lhe sucedam.

Ainda sobre a questão da autoria, segundo Bakhtin (2003), o autor se complementa no excedente de visão possível somente ao leitor, que é quem consegue visualizar o todo:

[...] deve colocar-se à margem de si, vivenciar a si mesmo não no plano em que efetivamente vivenciamos a nossa vida; só sob essa condição ele pode completar a si mesmo, até atingir o todo, com valores que a partir da própria vida são transgredientes a ela e lhe dão acabamento; ele deve tornar-se outro em relação a si mesmo, olhar para si mesmo com os olhos do outro; é verdade que até na vida procedemos assim a torto e a direito, avaliamos a nós mesmos do ponto de vista dos outros, através do outro procuramos compreender e levar em conta os momentos transgredientes à nossa própria consciência: desse modo, levamos em conta o valor da nossa imagem externa do ponto de vista da possível impressão que ela venha a causar no outro. (p. 13-14, grifos do autor)

Para ele, apesar de o autor ser conhecedor do todo, que é capaz de dar acabamento a uma obra, ele não deve viver do seu "[...] acabamento e do acabamento do acontecimento, nem agir", pois, ele precisa “[...] ser inacabado, aberto [...] ao menos em todos os momentos essenciais [...]." (BAKHTIN, 2003, p. 11)

A partir das ideias de Bakhtin, é possível compreender que o texto se complementa na interação do autor com o leitor, no excedente de visão próprio do leitor. Também nas palavras de Bakhtin (2002), “[...] a palavra é a arena onde se confrontam aos valores sociais contraditórios; os conflitos da língua refletem os conflitos de classe no interior mesmo do sistema: [...].” (p. 14, grifos do autor)

Nesse lugar de embates se constituiu a tríade "linguagem, sujeito e discurso/texto", no movimento característico do conhecimento, com cada elemento se complementando a partir das proposições de Geraldi, para pensar o ensino. 
Assim, considero que, em meio a deslocamentos e rearranjos, tendo o texto como objeto de ensino, na mediação entre sujeito e linguagem, conjuntamente com o pensamento de outros autores, o pensamento geraldiano se digladiou e também se somou a outros pensamentos em sua constituição, refletindo sobre questões ligadas à educação, e, mais especificamente, sobre o ensino.

E, com relação ao que representou a proposta de Geraldi para o ensino de língua portuguesa, como anteriormente me referi, para Mortatti (2000), foi uma "revolução conceitual"; para Freire (1990), uma "revolução"; a qual também caracterizo como uma "revolução conceitual”, em um momento de embates na área linguística que proporcionou pioneiramente o "deslocamento" das concepções linguísticas para o ensino de nossa língua. 
CAPÍTULO 6

CONCEITOS-CHAVE DO PENSAMENTO DE GERALDI

SOBRE O ENSINO DE LÍNGUA PORTUGUESA 
O pensamento de Geraldi sobre o ensino de língua portuguesa, "tematizado" especialmente em: O texto na sala de aula: leitura \& produção (1984), com ênfase nos cinco artigos de sua autoria; Portos de Passagem (1991); e Linguagem e ensino: exercícios de militância e divulgação (1996), está centrado em uma perspectiva interacionista de linguagem, o que significou uma "revolução conceitual" na história do ensino de língua portuguesa, assim como propus em minha dissertação de mestrado, $O$ ensino de língua portuguesa, segundo João Wanderley Geraldi (PAULA, 2004a).

Nos três livros, publicados ao longo de pouco mais de uma década, há a apresentação de uma proposta para o ensino de língua portuguesa, apoiada em três conceitos-chave: "linguagem", "sujeito" e "discurso", esse último, por sua vez, materializado no "texto", tomado por Geraldi como objeto de ensino. Esses conceitos-chave foram problematizados por Geraldi durante esses 12 anos que compreendem o período em que os seus três livros foram publicados.

Nos três livros, com relação ao interlocutor previsto, Geraldi contempla o professor de língua portuguesa, participante de seus cursos e projetos em todo o Brasil. Assim como menciona Franchi (1991), Geraldi estabelece um diálogo “de professor para professor”.

A propósito, esse diálogo é estabelecido principalmente a partir do desenvolvimento do "Projeto do Wanderley", destinado aos professores que atuavam no ensino de $1^{\circ}$. Grau, conforme nomenclatura da época ${ }^{165}$, e que havia sido inicialmente pensado e publicado como subsídios, intitulado "Subsídios metodológicos para o ensino de língua portuguesa: 5a a 8 a séries" (1981), como mencionei no Capítulo 3.

Primeiramente, o projeto se realizou em Aracaju/SE, em 1980, junto à Secretaria Estadual da Educação; em um segundo momento, ocorreu em Campinas, entre 1983 e 1984, junto à rede municipal de Educação; em 1985, na rede estadual paulista; a partir de 1984, na região oeste do Paraná; e depois, em toda a Secretaria Estadual da Educação paranaense; entre 1986 e 1987, desenvolveu-se na Secretaria Estadual da Educação de Mato Grosso do Sul, e posteriormente, em 18 regiões do estado do Mato Grosso do Sul, tendo tido uma enorme abrangência (GERALDI, FIAD, SILVA, 1989).

Quanto aos propósitos estabelecidos, em $O$ texto na sala de aula, livro utilizado para ministrar o "Projeto do Wanderley", Geraldi objetivava o diálogo com os professores de língua portuguesa, haja vista as condições de produção do livro: ser utilizado por professores que participariam do projeto no oeste do estado do Paraná. Naquele momento, procurava-se

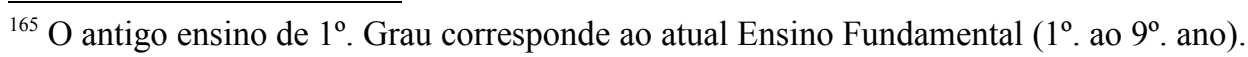


vincular o projeto pedagógico ao político, na tentativa de resgatar a autonomia do professor. Segundo Geraldi (1984), nesse livro, há: “[...] linhas de trabalho possíveis, algumas considerações teóricas e relatos de experiências de construção e aplicação de algumas das idéias defendidas pelos autores nos textos" (p. 5).

Em Portos de passagem, livro resultante de sua tese de doutorado, estabelecendo diálogos com os professores universitários, Geraldi apresenta resultados do trabalho realizado junto aos professores que participavam do "Projeto do Wanderley", considerando o momento de produção de sua tese: dez anos em que esteve envolvido com a divulgação de sua proposta.

E, em Linguagem e ensino: exercícios de militância e divulgação, por sua vez, são apresentados os resultados de sua participação em eventos, e, como sugerido no título, é proposta, nos textos que o compõem, a relação entre linguagem e ensino, estabelecida na sala de aula, e a qual Geraldi conhece a partir de seu diálogo com professores durante os inúmeros eventos e cursos de que participou, como comunicador.

Ainda com relação aos objetivos de sua proposta, desde a publicação de "Subsídios metodológicos...”, Geraldi pretende apenas subsidiar o trabalho do professor. Por esse motivo, "Subsídios metodológicos..." não se apresenta como um manual a ser seguido por professores em sala de aula.

Quanto às suas proposições, em $O$ texto na sala de aula, considerando a necessidade de transformação do ensino de língua portuguesa, Geraldi pensou em uma proposta para esse ensino, preocupando-se, principalmente, com o trabalho desenvolvido em sala de aula, para o qual sugeriu três práticas: leitura, produção e análise linguística de textos.

Em Portos de passagem, o eixo da proposta de Geraldi continuou voltado para as mesmas concepções de linguagem, sujeito e discurso/texto. No entanto, há o aprofundamento teórico dos aspectos: "historicidade da linguagem", "sujeito e atividades lingüísticas" e “contexto social das interações verbais".

Por "historicidade da linguagem", Geraldi situa o "[...] movimento constitutivo da linguagem, movimento que se dá na história pelo trabalho de sujeitos" (1991a, p. 15). Por "trabalho de sujeitos", por sua vez, ele considera as operações discursivas de que os sujeitos participam. Com relação às atividades linguísticas, considerando as atividades de reflexão, Geraldi distingue entre as ações que se fazem com a linguagem, as que se fazem sobre a linguagem e as $d a$ linguagem, considerando-as, respectivamente: atividades linguísticas, epilinguísticas e metalinguísticas. Para ele, as atividades linguísticas “[...] são aquelas que, praticadas nos processos interacionais, referem ao assunto em pauta, 'vão de si', permitindo a progressão do assunto" (GERALDI, 1991a, p. 20); as atividades epilinguísticas resultam de 
reflexões que tomam os próprios recursos expressivos como seu objeto; e as atividades metalinguísticas são as que analisam a linguagem, "construindo conceitos e classificações". Dentre elas, as atividades epilinguísticas são caracterizadas por Geraldi como fundamentais no trabalho com a linguagem na escola: “[...] condição para a busca significativa de outras reflexões sobre a linguagem" (1991a, p. 191-192).

Quanto ao "contexto social das interações verbais", Geraldi o considera, tendo em vista os seguintes aspectos:

a) porque as interações verbais não se dão fora do social mais amplo;

b) porque o ensino da língua, nosso objeto de preocupação mais imediato, não está infenso às interferências do sistema escolar e este do sistema social. (GERALDI, 1991a, p. 61)

Já no livro Linguagem e ensino, são apresentados os resultados da divulgação de sua proposta, assim como a reflexão aprofundada sobre a concepção de sujeito. Nesse livro, Geraldi relaciona as diferentes concepções teóricas advindas do: Estruturalismo Linguístico, da Análise do Discurso e da Teoria da Enunciação. A partir, então, dessas concepções, critica o Estruturalismo, por não focalizar o sujeito, e a Análise do Discurso, por concebê-lo como "assujeitado", já que esta o considera como sendo produzido nas "formações discursivas", que, por sua vez, sufocam-no. Priorizando as concepções advindas da Teoria da Enunciação, Geraldi caracteriza o sujeito produtor de seu discurso por meio da linguagem, mesmo recebendo contribuições das interações de que participou. Sob esse modo de pensar, o sujeito, para Geraldi, constitui-se na e pela linguagem, esta cujas concepções, em Geraldi, são pautadas a partir do pensamento de Bakhtin:

[...] entende-se que o sujeito se constitui como tal à medida que interage com os outros, sua consciência e seu conhecimento do mundo resultam como "produto sempre inacabado" deste mesmo processo no qual o sujeito internaliza a linguagem e constitui-se como ser social [...] (GERALDI, 1996a, p. 19)

Nesse livro, são também abordadas questões que passaram a ser pensadas pelo autor a partir da divulgação de sua proposta em todo o território nacional, assim como ocorreu com a alfabetização. Sobre esta questão, em um primeiro momento, Geraldi não a contempla em sua proposta. Ele mesmo salienta que, quando iniciou o seu projeto, "O ângulo redutor com que via a realidade me exigia definir meus cursos (aqueles que o departamento me atribuía) sem considerar [...] a precariedade da situação de ensino nos níveis inferiores [...]" (GERALDI, 1991a, p. XXII). 
Quanto aos conceitos-chave da proposta de Geraldi, a respeito da linguagem, tem lugar privilegiado em seu pensamento uma concepção que se apóia no social e que privilegia a interlocução, diálogo entre sujeitos, característica da Linguística da Enunciação. Especialmente em $O$ texto na sala de aula, Geraldi discorre sobre o fato de "[...] os falantes serem reconhecidos como sujeitos nas relações sociais" (1984, p. 45), tendo espaço para a "produção da linguagem". Nesse sentido, a linguagem só é possível porque o "locutor é o sujeito de seu dizer" (p. 45).

No entanto, no decorrer da divulgação de sua proposta, essa concepção de linguagem que privilegia a interlocução foi se aprofundando teoricamente, sobretudo em Portos de passagem, com especial destaque para a apresentação da "linguagem como atividade constitutiva". Ao empregar essa expressão, "linguagem como atividade constitutiva", pioneiramente utilizada por Franchi em sua tese e no artigo "Linguagem: atividade constitutiva" (1977), Geraldi retoma o pensamento desse autor, para quem: "Não há nada imanente na linguagem, salvo sua força criadora e constitutiva, embora certos 'cortes' metodológicos e restrições possam mostrar um quadro estável e constituído" (FRANCHI, 1977, p. 22, grifo meu)

Para Geraldi, a linguagem é constitutiva tanto dela mesma quanto do sujeito. Dessa forma, em sua proposta, estão imbricados linguagem e sujeito, numa relação de constitutividade. Essa constituição acontece no movimento proporcionado pela "historicidade" e pelas "atividades reflexivas" que envolvem o uso da linguagem, as quais devem sobrepor-se às atividades que apenas a descrevem.

Pensando assim, Geraldi considera que, na sala de aula, não há sujeito quando ao aluno é imposta uma função à qual ele deve obedecer para reproduzir o que lhe é ensinado, ao que denomina "aluno-função". Nessa reflexão, está contida a concepção foucaultiana sobre "mecanismos de controle de discursos" (GERALDI, 1991a, p. 61), mencionada especialmente em Portos de passagem. Para Geraldi, a consciência do sujeito se forma no discurso, e, a partir das interações de que participa, é constituído seu "sistema de referências" ${ }^{166}$, com o qual o sujeito relaciona o que conhece, sendo capaz de construir a sua compreensão sobre o mundo, numa relação histórica e social, na qual "[...] os recursos expressivos se tornam significativos" (1991a, p. 16).

No entanto, apesar de criticar a concepção da Análise do Discurso pelo “assujeitamento" do autor do discurso, Geraldi não nega a importância e a contribuição dessa

${ }^{166}$ Segundo Trask (2006), uma referência é “A relação entre uma expressão lingüística e alguma coisa que ela seleciona no mundo real ou conceitual. Uma expressão lingüística que refere a ou aponta para alguma coisa no mundo não lingüístico é uma expressão referencial [...]” (p. 251). 
teoria para os estudos linguísticos quando propõe o estudo do "discurso", ou seja, quando se refere às interações verbais em que os enunciados acontecem. Assim, abordando essas concepções de linguagem e de sujeito, quando Geraldi propõe o trabalho com o texto em sala de aula, tomando-o como objeto de ensino, apóia-se em concepções advindas da teoria da Análise do Discurso de linha francesa.

Dessa forma, é considerando a linguagem como atividade constitutiva dela mesma e do sujeito, e o discurso, materializado no texto, sendo considerado, por sua vez, como objeto de ensino, que Geraldi propõe três práticas para o ensino de língua portuguesa: leitura, produção e análise linguística de texto.

A partir da utilização do "texto na sala de aula", Geraldi o considera como "portos de passagem" para o trabalho com a "linguagem e o ensino", trabalho que deve se realizar por meio de atividades de leitura, produção e análise linguística de textos.

As três práticas propostas por Geraldi, para o ensino de língua portuguesa, enfatizam a importância da ação pedagógica mediadora entre autor, texto e leitor, e objetivam o aprendizado de atividades que oportunizam ao aluno o conhecimento de uma língua diferente da que ele fala. Trata-se de proporcionar ao aluno a vivência de uma língua-padrão a partir da reflexão sobre ela, combatendo, ao mesmo tempo, a "prática artificial da linguagem", tão criticada por Geraldi.

Sobre essa "prática artificial da linguagem", Geraldi considera que ela acontece quando a "[...] produção de textos na escola foge totalmente ao sentido de uso da língua: os alunos escrevem para o professor (único leitor, quando lê os textos)" (1984, p. 54). Em sala de aula, segundo Geraldi, as atividades devem ter finalidades verdadeiras, por exemplo, para a prática de produção de textos, deve-se pensar como proceder para que os textos dos alunos sejam lidos por diferentes leitores, e não apenas pelo professor.

Com relação à atividade de leitura de textos, ela é proposta, pelo autor, como uma oportunidade de o aluno aprender com o outro, o que acontece quando este não apenas interpreta e analisa textos, mas quando dialoga com o texto, sendo, o professor, caracterizado como mais um leitor desse mesmo texto.

Em O texto na sala de aula, especificamente no artigo "O circuito do livro e a escola", de Geraldi e Fonseca, referindo-se à quantidade de livros lidos pelos alunos, os autores consideram que essa quantidade é indício de qualidade, haja vista a maior possibilidade que propiciam ao leitor de poder comparar as diferentes leituras realizadas. Essa atividade, denominada por Geraldi e Fonseca (1984) “circuito do livro", indica também a preocupação com uma quantidade de livros que seja suficiente para o desenvolvimento da atividade de 
leitura. No momento de publicação de $O$ texto na sala de aula, o número de livros era reduzido em algumas escolas, o que, no entendimento desses autores, prejudicava o desenvolvimento da atividade.

Com relação ao texto, no interior da atividade de leitura, para Geraldi, ele se constitui como ponto de encontro entre autor e leitor: "O leitor trabalha para reconstruir este dito baseado também no que se disse e em suas próprias contrapalavras” (1991a, p. 167).

Em Linguagem e ensino, sobre a atividade de leitura, Geraldi afirma que os horizontes são expandidos numa "relação dialógica de construção" (1996a, p.104), com o comprometimento de todos, assim como de suas histórias de vida: “[...] o texto produzido completa-se na leitura. Neste sentido, o texto é condição para a leitura; a leitura vivifica os textos" (1996, p. 112). Nesse livro, o autor também critica a leitura realizada em âmbito escolar, que toma os diferentes tipos de texto apenas como modelos.

Autor e leitor, pertencentes a uma mesma sociedade onde se constituiu, pelo
trabalho de todos, o sistema lingüístico, sabem um e outro que as estratégias
de dizer implicam sentidos e efeitos de sentido. Ora, não pode, pois, o leitor
atribuir qualquer sentido às expressões usadas pelo autor: ao atribuir um
sentido, o leitor parte das pistas fornecidas pelo autor, associa-as a seus
próprios fios, para produzir o sentido em sua leitura. Aqui, pode o leitor
produzir, em sua caminhada interpretativa, leituras inadequadas. Caberá ao
professor não a correção de tal leitura, mas descobrir com o leitor os passos
desta caminhada, para que este leitor/aluno perceba onde os encadeamentos
feitos poderão estar sendo responsáveis pelo sentido final inadequadamente
produzido. (p. 125-126)

Para Geraldi (1991a, p. 171-174), o leitor lê o texto conduzido por diferentes objetivos, que o levam às práticas de leitura possíveis de serem realizadas na escola, as quais parafraseio:

a) leitura-busca-de-informações: conduz as perguntas de um leitor a um texto;

b) leitura-estudo-do-texto: trata-se da leitura responsável pelo encontro, no texto, de tudo o que é possível ler nele;

c) leitura-uso-do-texto ou pretexto: corresponde à leitura que se pode fazer de um texto para buscar nele um pretexto para a realização de outras atividades, ou mesmo de outro texto; e d) leitura-fruição-do-texto: é uma leitura prazerosa, sem a obrigação de ler para buscar algo no texto.

Quanto à prática de produção de texto, Geraldi a considera como prática central do ensino de língua portuguesa, para a qual estabelece um paradoxo entre as expressões “escrever redações" e "produzir textos". Ele introduz a concepção de que a redação é um texto para a escola, enquanto a produção de texto é o "[...] ponto de partida (e ponto de 
chegada) de todo o processo de ensino/aprendizagem da língua” (1991a, p. 135). Com relação a essa questão, Geraldi critica a escola, onde, segundo ele, ensina-se a "escrever redação", o que nada mais é do que a simulação de uma escrita que perde sua importância por não se tratar de uma situação real.

A propósito, contrapondo-se a uma prática denominada por Geraldi "artificial”, como anteriormente comentado neste mesmo capítulo, ao produzir um texto, o aluno deve ter um objetivo definido vinculado à sua realidade, mesmo que não pretenda ser um escritor, mas deve compreender o texto que produz, e como o produz.

Apoiando-se na teoria foucaultiana sobre os "mecanismos de controle", segundo a qual "O controle dos discursos se dá pelo controle de suas possibilidades de surgimento" (GERALDI, 1991a, p. 61) e "Quanto maior for o controle sobre o encontro dos sujeitos (interações), maior o controle dos discursos e, por esta via, o controle da produção de sentidos” (p. 62), Geraldi afirma que o uso da linguagem denuncia esses inúmeros "mecanismos de controle". Assim, “[...] numa sociedade altamente dividida, produzem-se também recursos expressivos distintos. No ensino da língua, estas questões são presença constante" (GERALDI, 1991a, p. 72).

Tomando esses aspectos de "controle", Geraldi elabora um "quadro de hipóteses", no qual o aluno se apoiaria, na escola, para produzir um texto:

a) Quem sou eu para lhe falar assim? b) Quem é ele para eu lhe falar assim?

c) Quem sou (professor) para que ele me fale assim? d) Quem é ele (aluno) para que ele me fale assim? e) De que lhe falo eu? f) De que ele (aluno) me fala? g) $\mathrm{O}$ que ele pretende de mim falando desta forma? h) O que o aluno pretende de si próprio falando assim? (1991a, p. 61-72)

Considerando essas hipóteses, para Geraldi, é imprescindível que, numa produção textual, ao produzir o texto:
a) se tenha o que dizer;
b) se tenha uma razão para dizer o que se tem a dizer;
c) se tenha para quem dizer o que se tem a dizer;
d) o locutor se constitua como tal, enquanto sujeito que diz o que diz para quem diz (ou, na imagem wittgensteiniana, seja um jogador no jogo);
e) se escolham as estratégias para realizar (a), (b), (c) e (d). (1991a, p. 137)

Dessa forma, somente após a realização da prática de produção de texto, quando os professores estiverem com os textos dos alunos em mãos, é que devem iniciar, sob o ponto de vista de Geraldi, a prática de análise linguística, a partir do texto do aluno.

Sobre a expressão "análise lingüística”, Geraldi considera:

[...] o conjunto de atividades que tomam uma das características da linguagem como seu objeto: o fato de ela poder remeter a si própria, ou seja, 
com a linguagem não só falamos sobre o mundo ou sobre nossa relação com as coisas, mas também falamos sobre como falamos. (1991a, p. 189-190)

Sob esse aspecto, o autor critica o ensino da Gramática Tradicional, que vinha sendo praticado nas escolas até a década de 1980, sem que houvesse reflexão sobre a prática da linguagem. Com relação à Gramática Tradicional, busco em Trask (2006) a seguinte definição:

Todo o corpo de doutrina gramatical elaborado na Europa e na América, antes do aparecimento da lingüística moderna no século XX. A tradição gramatical européia começou com os gregos e foi continuada pelos romanos, uns e outros principalmente interessados em descreverem suas próprias línguas. (p. 130)

Nesse trabalho com o ensino de língua portuguesa, como o propõe Geraldi, as relações entre os sujeitos são enfatizadas como mais significativas do que as atividades descritivas da linguagem. A análise linguística, por sua vez, faz o aluno pensar sobre a linguagem, sendo levado à produção de mais conhecimentos sobre ela. Em Portos de passagem, Geraldi propõe ações para o ensino de língua portuguesa em sala de aula e as toma por base para o ensino: as atividades epilinguísticas são pontos de apoio para as reflexões sobre a língua, constituindo-se em um ir e vir ao texto do aluno.

No entanto, Geraldi não pretende que o trabalho com a metalinguagem seja excluído da sala de aula, mas sim, que ele funcione como fonte de reflexões linguísticas já realizadas, propiciando outras reflexões em sala de aula.

Essas práticas propostas por ele se contrapuseram tanto à utilização do livro didático, incluindo o uso das cartilhas de alfabetização nas séries iniciais de escolarização, quanto ao ensino da Gramática Tradicional, ambas práticas escolares correntes até o final da década de 1970 no Brasil.

Quanto ao livro didático, ele é criticado por Geraldi, dentre outros motivos, por apresentar atividades prontas, sem ser possível ao professor a realização de um trabalho de reflexão sobre a linguagem, ficando restrito apenas à aplicação dessas atividades. Dessa forma, sob o seu ponto de vista, o problema que se pretendia resolver por meio do livro, a falta de formação linguística dos professores, somente acarretava mais problemas, pois o professor, a partir da utilização do livro didático, era apenas um mero transmissor das atividades propostas.

No que se refere ao ensino da Gramática Tradicional nas escolas, Geraldi critica o fato de não ser proposta nenhuma reflexão sobre a língua na prática escolar, mas apenas "análises de análises já existentes”, sem que, para isso, possa ser exercitada a linguagem. Para ele, 
aprender a linguagem é um processo que pressupõe a reflexão sobre ela mesma. E, sob esse seu ponto de vista, no ensino de língua portuguesa, quando o aluno reflete sobre a língua, ele aprende como acontece o seu processo de constituição, sendo-lhe possível essa reflexão de maneira autônoma.

No entanto, Geraldi não aborda somente a linguagem e o ensino, pois seu pensamento busca, ao mesmo tempo, um "encontro" entre concepções filosóficas, artísticas, políticas, literárias e científicas, que lhe permitem o diferencial de seu pensamento arguto.

Algumas expressões, usadas ainda hoje por professores, referem-se ao pensamento de Geraldi sobre o ensino de língua portuguesa: "pensar o ensino de língua portuguesa sob a luz da linguagem", “o sujeito como produtor de seu dizer", "três práticas para o ensino de língua portuguesa", "o trabalho com o texto na sala de aula", "produzir textos", "análise linguística" e "prática não-artificial da linguagem". Enfim, todas essas expressões estão pautadas nos conceitos-chave da proposta de Geraldi para o ensino de língua portuguesa: linguagem, sujeito e discurso/texto e demonstram a importância, a influência e a abrangência que o pensamento dele teve e ainda tem para o ensino de nossa língua. 
No Brasil, na década de 1980, os brasileiros viviam o fim da Ditadura Militar ${ }^{167}$, após o controle político de militares, tendo passado por muitas prisões, exílios e "ideias sufocadas". Principalmente nos anos 1960, os brasileiros tiveram problemas com relação ao "estado de direito", durante a Ditadura Militar, e muitos intelectuais foram exilados.

Dessa forma, naquele momento, aos professores, assim como a toda a sociedade civil, não era permitida a veiculação de ideias contrárias à Ditadura Militar.

Somente após esse período de controle, a partir da abertura política, voltou a ocorrer a proliferação de novas ideias e também de novas práticas. Assim como se refere Russell (2002), contrapondo-se às ideias em voga anteriormente, são pensadas novas ideias, que lhes imprimem tom de combate, assim como é: "[...] a partir de um sentimento de opressão que o existencialismo lança a sua rebelião contra o racionalismo" (p. 441).

Da mesma forma, Chartier (1988) afirma que "[...] as categorias aparentemente mais invariáveis devem ser construídas na descontinuidade das trajectórias históricas” (p. 27). Nesse sentido, de acordo com o autor,

As estruturas do mundo social não são um dado objectivo, tal como não o são as categorias intelectuais e psicológicas: todas elas são historicamente produzidas pelas práticas articuladas (políticas, sociais, discursivas) que constroem as suas figuras. São estas demarcações, e os esquemas que as modelam, que constituem o objecto de uma história cultural levada a repensar completamente a relação tradicionalmente postulada entre o social, identificado com um real bem real, existindo por si próprio, e as representações, supostas como reflectindo-o ou dele se desviando. (CHARTIER, 1988, p. 27)

Segundo Ghiraldelli (1994), após a anistia política, com o retorno dos exilados, em 1979, e as eleições diretas de governadores dos Estados, em 1982, a liberdade de pensamento e de opinião, assim como a leitura de inúmeros textos de professores acadêmicos, ganharam visibilidade, a fim de que fossem discutidos aspectos relativos à educação brasileira de uma maneira geral, para que não houvesse impasses que suspendessem a redemocratização.

Os professores universitários, por sua vez, desde a década de 1970, vinham se organizando em busca de mudanças, e o governo militar João Baptista Figueiredo não conseguiu mais controlar esse anseio da sociedade. Instaurava-se uma vontade nacional que incitava transformações, e que, consequentemente, proporcionou a produção de novas ideias,

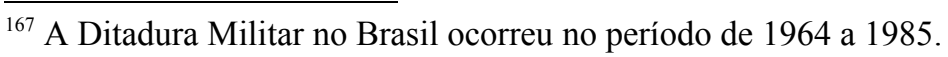


textos e propostas. A partir dessa abertura política, foi possível a todos os brasileiros, dentre outras questões, conhecer textos ainda inéditos no Brasil.

Com relação às mudanças nos aspectos educacionais brasileiros, na década de 1980 , são elucidativas as contribuições de Magnani (2001), Palma Filho (2003) e Saviani (2008).

Naquele momento, havia, em especial, uma inconformidade com relação à situação de repetência e evasão dos alunos nas escolas brasileiras. Segundo Magnani (2001), em meados da década de 1980, muito se pensava sobre os novos rumos da educação brasileira,

Associadamente ao processo de abertura política, assim como ocorria nas demais esferas da atividade social, também na educação vivia-se o clima de denúncias dos efeitos da crise resultante dos anos de ditadura e de busca de propostas concretas de solução para seu enfrentamento e superação. (p. XIII)

Nas universidades, os professores/pesquisadores investigavam respostas para os inúmeros problemas educacionais. Sobre essa questão, Magnani (2001) salienta:

O curso de pós-graduação em Educação da UNICAMP era ainda recente, mas já vinha se destacando no cenário acadêmico brasileiro, mediante a produção e difusão, por parte de alguns de seus professores-pesquisadores, de análises dos problemas educacionais centrados em referenciais teóricometodológicos advindos de uma certa sociologia de orientação dialéticomarxista. A essa característica, acrescentava-se a abrangência da área de Educação, o que possibilitava abordagem de temas mais diversificados e ainda pouco explorados. (p. XIV)

Segundo Palma Filho (2003), com relação às ações político-educacionais propostas pela Secretaria da Educação do Estado de São Paulo (SEE), por meio da Coordenadoria de Estudos e Normas Pedagógicas (CENP), ocorrida durante o Governo de André Franco Montoro $^{168}$, de 1983 a 1986, no estado de São Paulo, dois importantes programas eram postos em discussão: o Ciclo Básico de Alfabetização (CBA) ${ }^{169}$ e a reforma curricular ${ }^{170}$.

Nesse governo, a grande maioria desses profissionais, na época,

[...] apontou aspectos de natureza estrutural que impediam a melhoria educacional da rede estadual pública. Nesse sentido, reclamavam por mudanças que implicavam uma nova reorganização didático-pedagógica da escola. Além disto, apontaram a necessidade de uma séria e profunda revisão

${ }^{168}$ Segundo Palma Filho (2003), o governo Montoro estava "[...] lastreado em um programa que, para o setor educacional, priorizava a descentralização administrativa e a participação dos agentes educacionais no processo de tomada de decisões." (p. 18)

169 O Projeto Ciclo Básico de Alfabetização foi instituído pela Secretaria de Educação do Estado de São Paulo (SE/SP), a partir da publicação do Decreto Estadual $n^{\circ} .21 .833$, de 28 de dezembro de 1983, e regulamentado pela Resolução da Secretaria da Educação, n. 13/84, de 18 de janeiro de 1984.

${ }^{170}$ Segundo Palma Filho (2003, p. 20), "Em meados dos anos 1980, a Secretaria de Estado da Educação do Estado de São Paulo, através da Coordenadoria de Estudos e Normas Pedagógicas (CENP) em conjunto com professores das Universidades Estaduais do Estado de São Paulo deu início ao processo de revisão dos Guias Curriculares, que até então era o currículo oficial das escolas estaduais de ensino fundamental e de ensino médio." 
dos conteúdos curriculares, que adequasse o currículo escolar à nova realidade vivida pela escola pública paulista após a expansão da matrícula e a criação da escola de primeiro grau, que reunia o grupo escolar e o ginásio num continuum, sem, entretanto, lograr o entrosamento entre essas duas escolas. Tal fato era corroborado pelos elevados índices de repetência e evasão na passagem da $5^{\mathrm{a}}$. para a $6^{\mathrm{a}}$. série, conseqüência da descontinuidade existente na passagem da $4^{\mathrm{a}}$. para a $5^{\mathrm{a}}$. série. (PALMA FILHO, 2003, p. 22)

Concomitantemente à organização do CBA, foi considerada, por Palma Filho (2003), de igual importância também a reorganização do currículo do ensino fundamental. Dessa reorganização do currículo, participaram professores, coordenados pela CENP, que foram assessorados por professores universitários da USP, da UNICAMP, da Unesp e da PUC/SP. Dentre os aspectos discutidos, esse autor salienta a importância dos conteúdos que eram escolhidos, assim como a sua relevância social; a sistematização e a organização das disciplinas; o conhecimento para a escolha de uma teoria de aprendizagem e das condições de trabalho na escola. A partir dessas considerações, para o conteúdo de Língua Portuguesa, o autor considera que havia:

[...] uma preocupação no sentido de levar o aluno a produzir o seu próprio texto oral ou escrito, interpretando mensagens recebidas, estimulando atividades de reflexão e operação sobre a linguagem. Respeito ao "dialeto" do aluno e conscientização do valor expressivo desse "dialeto". Levava em conta os seguintes princípios teóricos: a) ênfase no caráter social da linguagem; b) consideração de que a atividade de linguagem se realiza nos processos reais de comunicação como discurso ou texto; c) predominância das atividades de linguagem e do trabalho com o texto sobre a descrição gramatical (respeitada essa ordem na introdução de quaisquer conteúdos). (PALMA FILHO, 2003, p. 29)

Sobre a proposta curricular, Palma Filho (2003) considera que,

[...] apesar de todas as dificuldades e contratempos, a reforma curricular, ao menos enquanto proposta teórica, trouxe uma contribuição valiosa na direção da construção de um currículo escolar, com foco na transformação social, voltada para a edificação de uma sociedade mais justa, mais inclusiva, que continua a ser a grande utopia educacional para aqueles que não aceitam ser a escola apenas um aparelho ideológico do Estado, voltado para a reprodução da injustiça social, e que outra escolha não têm a não ser dar vida a essa utopia. (p. 57)

Também com relação ao período de redemocratização política, segundo Saviani (2008), “a década mais fecunda de nossa história", e as suas interferências nos aspectos educacionais em nosso país,

[havia] a busca de teorias que não apenas se constituíssem como alternativas à pedagogia oficial, mas a ela se contrapusessem. Eis o problema que emergiu naquele momento: a necessidade de construir pedagogias contra- 
hegemônicas, isto é, que em lugar de servir aos interesses dominantes se articulassem com os interesses dominados. (p. 402)

Naquele momento, as chamadas "pedagogias críticas" orientavam a prática educativa brasileira.

Os anos de 1980 inauguram-se com a existência da Associação Nacional de Educação (ANDE), Associação Nacional de Pós-Graduação e Pesquisa em Educação (ANPED) e o Centro de Estudos Educação e Sociedade (CEDES), surgidos, respectivamente, em 1979, 1977 e 1978. Mas, além dessas entidades destinadas a congregar educadores independentemente de sua vinculação profissional, a década de 1980 também se inicia com a constituição de associações, depois transformadas em sindicatos, aglutinando, em âmbito nacional, os professores dos diferentes níveis de ensino e os especialistas nas diversas habilitações pedagógicas. (SAVIANI, 2008, p. 403)

De acordo com Saviani (2008), após a Constituição de 1988, essas associações se transformaram em sindicatos filiados a uma central nacional, a Central Única dos Trabalhadores (CUT), e os professores se organizaram em sindicatos. A preocupação instaurada se referia à:

[...] preocupação com o significado social e político da educação, do qual decorre a busca de uma escola pública de qualidade, aberta a toda a população e voltada precipuamente para as necessidades da maioria, isto é, a classe trabalhadora; e outro marcado pela preocupação com o aspecto econômico-corporativo, portanto, de caráter reivindicativo, cuja expressão mais saliente é dada pelo fenômeno das greves que eclodiram a partir do final dos anos de 1970 e se repetiram em ritmo, freqüência e duração crescentes ao longo da década de 1980. (SAVIANI, 2008, p. 404)

Tanto as revistas da ANDE e do CEDES, quanto as Reuniões Anuais da ANPED visavam a atender a objetivos comuns. Em parte, segundo Saviani (2008), é possível constatar essa questão pela organização das três entidades para a Conferência Brasileira de Educação, que ocorreu em 1980. Naquela década, de acordo com Saviani (2008), alguns governos estaduais que se opunham ao regime militar propuseram medidas de política educacional ${ }^{171}$.

Para o autor, ocorreram também, dentre outras, as seguintes ações: ampliação da produção acadêmico-científica; circulação de cerca de 60 revistas de educação da época; e a publicação de uma grande quantidade de livros. Algumas editoras, de prestígio naquele

\footnotetext{
171 Segundo Saviani (2008), em Minas Gerais, o Congresso Mineiro de Educação propôs o combate ao clientelismo e o fim do privatismo, centralizando a discussão da educação escolar pública; em São Paulo, foram implantados o ciclo básico, o estatuto do magistério, os conselhos de escola e a reforma curricular; no Paraná, ocorrem as eleições para diretores e regimentos escolares; no Rio de Janeiro, inauguram-se os Centros Integrados de Educação Pública (CIEPS); em Santa Catarina, o governo não era da oposição, mas realizou um congresso estadual de educação sobre medidas político-administrativas da educação do estado.
} 
momento, lançaram coleções de educação, além de terem sido fundadas editoras especializadas na área.

Para Saviani (2008), a educação, naquele momento, ganhou reconhecimento em âmbito científico, o que se comprova em parte pelo financiamento pela SBPC e pelas agências federais de fomento à pesquisa e ao ensino: $\mathrm{CNPq}$, Coordenação de Aperfeiçoamento de Pessoal de Nível Superior (CAPES), Financiadora de Estudos e Projetos (FINEP), e pelas fundações de amparo à pesquisa de vários estados: Fundação de amparo à pesquisa do estado de São Paulo (FAPESP), Fundação de amparo à pesquisa do estado de Minas Gerais (FAPEMIG), Fundação de amparo à pesquisa do estado do Rio de Janeiro (FAPERJ) e Fundação de amparo à pesquisa do estado do Rio Grande do Sul (FAPERGS).

No âmbito educacional, destacaram-se, no período, as seguintes revistas: Educação \& sociedade, ligada ao Centro de Estudos Educação \& Sociedade (CEDES), e $A N D E$, vinculada à Associação Nacional de Educação (ANDE).

Também abordando aspectos ligados à educação brasileira da década de 1980, especialmente sobre o ensino de leitura e escrita, são elucidativas as contribuições de: Mortatti (2000), Ilari (1985), Geraldi, Silva e Fiad (1996) e Geraldi (1985, 2004a, 2006a).

Sobre a história do ensino da leitura e escrita no Brasil, especialmente sobre a alfabetização, Mortatti (2000) propõe "quatro momentos cruciais": no "primeiro momento crucial", ocorre a disputa entre os defensores do "método João de Deus", de fundamentação teórica positivista, baseado na palavração e contido na Cartilha Maternal ou Arte da Leitura, do português João de Deus (Ramos), divulgado no Brasil por Silva Jardim, no início da década de 1880, e os defensores do método sintético, baseado na soletração e na silabação, utilizado nas primeiras cartilhas elaboradas por brasileiros; no "segundo momento crucial", ocorre a disputa entre os defensores do método analítico, formados pela Escola Normal de São Paulo, e os defensores do método sintético, preocupados, sobretudo, com a silabação. Nesse momento, há ainda uma outra disputa entre os "mais modernos" e os "modernos" defensores do método analítico, que divergiam quanto ao modo de processar o método analítico por meio da palavração, da sentenciação e da historieta; no "terceiro momento crucial", ocorre a disputa entre os defensores do método analítico e os do método misto (analítico-sintético ou sintético-analítico), sendo que há, nesse momento, uma "relativização" da importância do método; finalmente, no "quarto momento crucial", ocorre a disputa entre os defensores dos métodos tradicionais, principalmente do método misto, e os defensores do construtivismo de Emília Ferreiro, e, depois, ocorre a disputa entre os modernos e os mais 
modernos, os primeiros, defensores do construtivismo, e os segundos, do interacionismo, baseado na Psicologia Soviética, de Lev Vygotsky.

Nesse "quarto momento crucial", segundo a autora, que ocorre a partir do final da década de 1970, a escola, enquanto instituição, era considerada na sociedade como símbolo de mudança social. E a sociedade buscava, naquele momento, soluções para os problemas de repetência e evasão, como informei anteriormente neste capítulo.

No estado de São Paulo, ações foram desenvolvidas visando à incorporação do construtivismo como nova teoria para o ensino da leitura e da escrita. Segundo Mortatti (2000), a partir de 1980, a produção acadêmico-científica sobre educação, linguagem e alfabetização ganha expansão. Há, então, uma gradativa mudança na pesquisa sobre leitura e escrita: “[...] dos estudos centrados na psicologia de base associacionista e comportamentalista e na pedagogia que privilegia o método, para os estudos centrados na psicolingüística, na sociolingüística e lingüística.” (p. 274).

Nesse contexto, segundo Mortatti (2000), representando uma discordância em relação à teoria construtivista, surgem duas propostas: a proposta pioneira de J. W. Geraldi e a de Ana Luiza Smolka, ambas baseadas na perspectiva interacionista, partindo das questões sobre "por quê e para quê" ensinar.

Na década de 1980, a partir do interacionismo linguístico, na década de 1980, destacase o pensamento de J. W. Geraldi, no ensino da leitura e escrita,

[...] valendo-se das contribuições da Análise do Discurso, da Teoria da Enunciação e da Sociolingüística. Dessa abordagem resultam o deslocamento do eixo das discussões de como para por quê e para quê se ensina e se aprende a língua, a necessidade de conciliação entre pressupostos teóricos e procedimentos metodológicos e a ênfase na opção política do professor. (MORTATTI, 2000, p. 277, grifos da autora)

Enquanto Smolka aborda a língua escrita na fase inicial de escolarização das crianças, Geraldi, por sua vez, segundo Mortatti (2000, p. 277) “[...] não [trata] muitas vezes explicitamente da alfabetização [...], as tematizações de Geraldi podem ser consideradas emblemáticas em relação ao ensino da língua, [...]”.

As reflexões de Geraldi, contidas em "Subsídios...", O texto na sala de aula, Portos de passagem e Linguagem e ensino: militância e divulgação, têm abrangência em todo o Brasil, a partir do "Projeto do Wanderley", o qual mencionei no Capítulo 4.

Nesse contexto, em que novas ideias estavam em discussão, as ciências linguísticas trouxeram grandes contribuições para o ensino de língua portuguesa, pois apresentavam, dentre outras questões: uma nova concepção de linguagem, que passou a considerar a 
produção da linguagem na história, o sujeito como produtor de seu discurso e o discurso/texto, como objeto de ensino.

Nesse momento histórico em que as ciências linguísticas passaram a contribuir para o ensino de língua portuguesa, segundo Ilari (1985), provocou-se uma renovação no curso de Letras, pois “[...] as transformações quantitativas e qualitativas por que passou o ensino secundário tornaram cada vez mais óbvia a ineficiência das faculdades de letras tradicionais como centros de formação de professores para o ensino de língua materna" (p. 1-2). A partir de 1960, de acordo com Ilari, quando se iniciou essa contribuição da linguística para o ensino da língua portuguesa, houve muitas mudanças: nas Universidades, o estudo descritivo da língua foi ampliado e, nas escolas de ensino secundário, começaram a ser consideradas outras variedades linguísticas, diferentes da padrão. A linguística ocupou o espaço da Gramática Tradicional, proporcionando abertura de compreensão para as condições linguísticas da população brasileira. Assim, para Ilari (1985),

[...] os conhecimentos que a pesquisa lingüística produziu sobre a linguagem humana em geral e sobre a língua portuguesa em particular são hoje bem mais pormenorizados que as teses genéricas de inspiração estruturalista que constituíram o tema de reflexão da lingüística brasileira em seus primeiros momentos; isto permite que certas competências dos falantes nativos de Português possam ser observadas e explicadas com um rigor muito maior, preliminar indispensável para a formulação concreta de estratégias escolares (por exemplo: os conhecimentos hoje acumulados sobre fonética e fonologia do Português permitem equacionar com grande clareza os problemas especificamente lingüísticos envolvidos no processo de alfabetização, e tornam possível uma discussão objetiva da maneira como esses aspectos devem ser considerados nas estratégias e materiais didáticos) [...]. (p. 3-4).

Naquele momento de contribuição das concepções linguísticas, os professores/pesquisadores universitários, estudiosos dessas concepções, foram convidados a escrever um documento para a CENP, como subsídio ao trabalho curricular que se iniciaria no $2^{\circ}$. grau, a partir das ciências linguísticas, sobretudo, tendo por base as concepções da Análise do Discurso, da Teoria da Enunciação e da Sociolinguística.

Na década de 1980, foram elaborados dois documentos sobre educação e ensino que foram de grande importância nesse período: o Ciclo Básico de Alfabetização (1983) e a $1^{\text {a }}$. versão da Proposta Curricular para o ensino de Língua Portuguesa do estado de São Paulo ${ }^{172}$

${ }^{172}$ De acordo com informações que constam na Proposta Curricular para o ensino de Língua Portuguesa do estado de São Paulo, essa proposta foi elaborada pela CENP e revisada pelo professor Carlos Franchi, tendo tido o amparo da Lei n. 5988, de 14 de dezembro de 1973. Dela participaram: professores de $1^{\circ}$. e $2^{\circ}$. graus e professores/pesquisadores universitários. Dentre outras ações da CENP, anteriores e concomitantes à elaboração da Proposta Curricular para o ensino de Língua Portuguesa do estado de São Paulo, destacam-se: a publicação dos subsídios à proposta curricular de Língua Portuguesa para o $2^{\circ}$. Grau, com 8 volumes (1978); a organização 
(1985). Essas questões sobre educação e ensino também constam das Diretrizes para o aperfeiçoamento do ensino/aprendizagem da língua portuguesa ${ }^{173}$, elaboradas pela Comissão Nacional nomeada pelo Ministério da Educação (BRASIL, 1986), as quais contemplavam um ensino baseado nas práticas de leitura, produção e análise linguística de textos.

Buscavam-se transformações e, ao mesmo tempo, era exigida uma nova postura e identidade do professor. Por isso, a partir da década de 1980, e tendo em vista as concepções de linguagem baseadas na Gramática Gerativa, na Análise do Discurso, na Teoria da Enunciação e na Sociolinguística, Geraldi, em seus cursos de formação de professores, passou a apresentar, para eles, o texto como objeto de ensino a ser usado na sala de aula. Para Geraldi, Silva e Fiad (1996), cobrava-se, na época, que o professor estivesse engajado nesse conhecimento sobre o qual se discutia e que ele propusesse uma prática consciente em sala de aula.

Ainda de acordo com Geraldi, Silva e Fiad (1996), o processo de formação continuada de professores foi, então, encabeçado por Geraldi, no oeste do estado do Paraná, estendendose para vários estados do Brasil. Esses cursos visavam à qualidade de ensino, com a participação e a autonomia do professor, que se constituía por meio da necessidade de tal formação, diferentemente do que então existia como atividades prontas, nos livros didáticos adotados, como imposição de órgãos oficiais ${ }^{174}$. Geraldi participou desse processo, juntamente com outros professores do IEL/UNICAMP e de outras universidades.

Percebeu-se que, para haver o novo ensino de língua portuguesa, era necessário um professor que fosse capaz de articular os eixos epistemológicos e as necessidades didáticopedagógicas vigentes, pois o "exercício da capatazia", nos termos de Geraldi, já não se podia aceitar que fosse exercido pelo professor. A partir de uma nova concepção de linguagem, era exigida uma mobilidade do conhecimento.

O ensino de leitura e escrita das escolas brasileiras até a década de 1980, segundo Geraldi (2004a), estava baseado em atividades metalinguísticas, nas quais se usa a língua para descrever a própria língua. Essas atividades visavam apenas à descrição e à classificação da língua, sem que houvesse uma reflexão significativa sobre as atividades desse ensino. Além

de cursos em parceria com as universidades do estado de São Paulo - USP, UNICAMP, Unesp (a partir de 1981); a organização de monitorias (a partir de 1984); e a criação do Projeto Ipê (1985).

${ }^{173}$ Segundo informações que constam nas Diretrizes para o aperfeiçoamento do ensino/aprendizagem da língua portuguesa, essas diretrizes foram elaboradas pela Comissão Nacional para o Estabelecimento de Diretrizes que promovam o Aperfeiçoamento do Ensino/Aprendizagem da Língua Portuguesa, tendo sido criada pelo Decreto do Presidente da República nº 91 372, de 26 de janeiro de 1985.

${ }^{174}$ Nessa época, circulavam os "Guias Curriculares Nacionais", conhecidos pelos professores como "Verdão". Esse documento, resultante da Lei 5692/71, foi elaborado para a definição das diretrizes gerais para o ensino de $1^{\circ}$. e $2^{\circ}$. graus, correspondentes à atual Educação Básica. 
disso, a escola recebia alunos com "variantes linguísticas" diferentes, filhos de classes economicamente desfavorecidas, a quem lhe cabia ensinar a língua padrão, sem lhes depreciar a fala, como uma possibilidade de ascensão social, tal como se compreendia na época.

Dizer que uma variedade lingüística é errada ou inadequada é dizer que o modo como os sujeitos que a falam se constituíram é errado e inadequado: interditar formas lingüísticas é interditar sujeitos. Corrigir formas lingüísticas é trabalhar pela uniformidade, em benefício do mito da unidade, com prejuízos incalculáveis para a multiplicidade das formas de compreensão da vida. (GERALDI, 2006a, p. 70).

Ainda uma outra questão, sobre a qual Geraldi refletia no âmbito do ensino de leitura e escrita, era a utilização do livro didático ${ }^{175}$, que apresentava as atividades "prontas", desconsiderando a interlocução que deveria ocorrer em sala de aula entre professor e aluno.

Naquele momento, persistiam, dentre outros, os seguintes equívocos no ensino de leitura e escrita: o fato de o conhecimento gramatical ser indispensável a uma boa expressão; o ler e o escrever como atividades distantes da vida do aluno; a ideia de que lendo se aprende a escrever; e a separação de alfabetização e Língua Portuguesa (GERALDI, 1985). Tentando desmistificar esses equívocos, Geraldi explicava que o ensino de língua portuguesa deve ter por objetivos: a priorização da formação de usuários da língua; a leitura e a escrita como processos distintos; e a alfabetização e a Língua Portuguesa como integrantes do mesmo processo de ensino de língua (1985).

A partir da década de 1990, passou a ser divulgada, por meio da Lei de Diretrizes e Bases da Educação Nacional (LDB/EN 9394/96) e dos Parâmetros Curriculares Nacionais $(\mathrm{PCNs})^{176}$, a proposta de Geraldi para o ensino de língua portuguesa.

\footnotetext{
${ }^{175}$ Sobre tal questão, Geraldi, Ruiz, Fiad e Silva (1986) realizaram um trabalho de análise de livros didáticos específicos da década de 1980, focalizando a organização do conteúdo exposto nos livros e considerando a artificialidade de tais conteúdos. Os livros didáticos analisados foram quatro: 1. PRATES, Marilda. Reflexão e ação em Lingua Portuguesa. São Paulo: Editora do Brasil, 1984.; 2. SIQUEIRA, Antonio de; BERTOLIN, Rafael. Português dinâmico: comunicação e expressão. São Paulo: IBEP, 1978.; 3. CEGALA, Domingos Paschoal. Português fundamental: estudo dirigido. São Paulo: Cia. Ed. Nacional, 1973.; 4. MESQUITA, Roberto Melo; MARTOS, Cloder Rivas. PAI: comunicação e expressão. São Paulo: Saraiva, 1978.

176 Segundo Geraldi (1998, p. 20), as propostas governamentais para o ensino de língua portuguesa, tais como os $P C N s$, deveriam incluir uma estratégia de acompanhamento ao professor, a fim de que ele pudesse tirar as dúvidas que eventualmente surgissem.
} 
CONSIDERAÇÕES FINAIS

Nesta tese, mediante a análise da configuração textual dos três livros de Geraldi: $O$ texto na sala de aula: leitura \& produção, Portos de passagem e Linguagem e ensino: 
exercícios de militância e divulgação, nos quais considero estarem sintetizadas as ideias linguisticas constitutivas do pensamento desse autor sobre o ensino de língua portuguesa, procurei compreender as ideias linguísticas que constituem o pensamento de Geraldi sobre esse ensino no Brasil e quais "deslocamentos" são propostos por ele, para o ensino de nossa língua, a partir dessas ideias.

Para tanto, por meio das informações que localizei sobre a formação e a atuação profissional de Geraldi, foi possível compreender que, atuando ainda como bancário, no interior do Rio Grande do Sul, Geraldi teve o primeiro convite e contato com a sala de aula como professor, primeiramente de Geografia, e depois de Língua Portuguesa. Naquele momento, iniciou para ele a busca de respostas sobre o seu questionamento sobre ensinar a própria língua, quando passou a buscar formação na área: Licenciatura em Letras, Especialização e mestrado e doutorado em Linguística.

As primeiras aulas e a formação inicial ocorreram no auge das concepções do Estruturalismo linguístico, no momento em que se pensava sobre a prática de ensino de língua portuguesa a partir dessas concepções. No entanto, já no IEL/UNICAMP, no curso de PósGraduação, foi possível presenciar os embates de outras concepções linguísticas que se contrapunham ao Estruturalismo linguístico. Dentre outras, foi de extrema importância para o pensamento de Geraldi as concepções advindas da: Gramática Gerativa, Teoria da Enunciação, Análise do Discurso e Sociolinguística, com as quais pôde dialogar.

A partir dessa formação, em meio, em especial, às ideias franchianas sobre o ensino de língua portuguesa, às ideias bakhtinianas sobre linguagem e às ideias linguísticas de origem francesa, veiculadas no Brasil a partir da década de 1980, ele elaborou sua proposta para esse ensino.

Seus interlocutores eram os professores de língua portuguesa que participavam de seus cursos, os seus colegas, professores/pesquisadores que colaboravam na aplicação dos cursos e outros com os quais tinha contato no IEL/UNICAMP e em outras universidades brasileiras, com os quais aprendeu, complementando-se, considerando a incompletude, característica essencial do sujeito, segundo suas concepções.

No momento vivia-se o fim da Ditadura Militar, o que possibilitava transformações. Nesse âmbito, a proposta de Geraldi ganhou amplitude, não estando a salvo de críticas. Os embates ocorriam com autores que defendiam a utilização do livro didático em sala de aula e o ensino da Gramática Tradicional, ambas práticas desvinculadas de uma reflexão sobre e da linguagem, sob o ponto de vista geraldiano. 
Fundamentada especialmente na perspectiva interacionista, a proposta de Geraldi foi constituída pelos conceitos: linguagem, sujeito e discurso/texto, que ele deslocou de forma pioneira para o ensino de língua portuguesa, propondo três práticas para esse ensino: leitura, produção e análise linguística. A partir desse deslocamento, Geraldi foi o responsável pela "revolução conceitual" nesse ensino. 


\section{REFERÊNCIAS}

ANDRADE, Carlos Drummond de. Sentimento do mundo. Rio de Janeiro: Record, 2001. 
ARANHA, Maria Lúcia de Arruda. História da Educação. 2. ed. rev. e atual. São Paulo: Editora Moderna, 1996.

ATHAYDE JÚNIOR, Mario Candido. Articular vozes. Deslocar sentidos: o discurso de língua portuguesa em discursos oficiais e em falas de professores. Síntese, Campinas, n. 12, p. 55-65, 2007.

BAKHTIN, Mikhail. Marxismo e filosofia da linguagem. Tradução de Michel Lahud e Yara F. Vieira. 10. ed. São Paulo: HUCITEC, 2002.

2003.

. Estética da criação verbal. Tradução de Paulo Bezerra. 4. ed. São Paulo: Martins Fontes,

BATISTA, Antonio Augusto G. Apresentação. In: GERALDI, João Wanderley. Entrevista [11/12/1998]. Recuperando as práticas de interlocução na sala de aula. Entrevistadores: Graça Costa Val e Antônio Augusto G. Batista. Presença pedagógica, v. 4, n. 24, p. 5-19, 1998.

BENVENISTE, Émile. O aparelho formal da enunciação. In: BENVENISTE, Émile. Problemas de Lingüística Geral II. Tradução de Eduardo Guimarães et al. Campinas: Pontes, 1989a. p. 81-90.

.Estruturalismo e lingüística. In: BENVENISTE, Émile. Problemas de Lingüística Geral II. Tradução de Eduardo Guimarães et al. Campinas: Pontes, 1989b. p. 11-28.

. Da subjetividade na linguagem. In: BENVENISTE, Émile. Problemas de Lingüística Geral I. Tradução de Maria da Glória Novak e Maria Luisa Néri. 4. ed. Campinas: Pontes, 1995. p. 284-293.

BOTO, Carlota. Nova história e seus velhos dilemas. Revista USP, São Paulo, n. 23, p. 23-33, set./nov. 1994.

BRAIT, Beth. O discurso sob o olhar de Bakhtin. In: GREGOLIN, Maria do Rosário Valencise; BARONAS, Roberto. (Orgs.). Análise do discurso: as materialidades do sentido. 2. ed. São Carlos: Editora Claraluz, 2003. p. 19-30.

BRASIL. Lei de diretrizes e bases da educação nacional.Brasília, 11 de agosto de 1971.

BRITTO, Luiz Percival de Leme. Sujeito da linguagem, sujeito de ensino. In: BRITTO, Luiz Percival de Leme. A sombra do caos: ensino de língua X tradição gramatical, Campinas: Ed. Mercado de Letras/ALB, 1997. p. 153-165.

CHARAUDEAU, Patrick; MAINGUENEAU, Patrick. Dicionário de análise do discurso. Tradução de Fabiana Komesu. São Paulo: Contexto, 2004.

CHARTIER, Roger. A História Cultural: entre práticas e representações. Rio de Janeiro: Editora Bertrand Brasil S. A., 1988.

CHERVEL, André. História das disciplinares escolares: reflexões sobre um campo de pesquisa. Tradução de Guacira Lopes Louro. Teoria \& educação, Porto Alegre, n. 2, p. 177-229, 1990.

CHIAPPINI, Lígia. A circulação dos textos na escola: um projeto de fomação-pesquisa. GERALDI, João Wanderley; CITELLI, Beatriz (Coord.). Aprender e ensinar com textos de alunos. São Paulo: Cortez, 1997.

CLARK, Katerina; HOLQUIST, Michael. Mikhail Bakhtin. Tradução de J. Guinsburg. São Paulo: Perspectiva, 2004. 
COSTA, Iara Benquerer. Prefácio. In: GERALDI, João Wanderley. Subsídios metodológicos para o ensino de língua portuguesa: 5a a 8 . séries. Cadernos da FIDENE, Ijuí, n. 18, p. 70, 1981.

DANIEL, Maria Emília Borges. O ensino de português na Escola Normal e Modelo Anexa, de Campo Grande: 1930-1940. 2001. 327 f. Tese (Doutorado em Semiótica e Lingüística Geral) - Universidade de São Paulo, São Paulo.

DI RENZO, Ana Maria. Liceu Cuiabano: língua nacional, religião e estado. In: ORLANDI, Eni Pulcinelli; GUIMARÃES, Eduardo. (Org.) Institucionalização dos estudos da linguagem: a disciplinarização das idéias lingüísticas. Campinas: Pontes, 2002. p. 101-120.

DUCROT, Oswald. Estruturalismo e Lingüística. 2. ed. Tradução de José Paulo Paes. São Paulo: Editora Cultrix, 1971.

. O dizer e o dito. Tradução de Eduardo Guimarães. Campinas: Pontes, 1987.

FIAD, Raquel Salek. Um estudo de variantes textuais e sua contribuição ao ensino de língua materna. Cadernos de estudos lingüísticos, Campinas, n. 24, p. 35-39, 1993.

FONSECA, Maria Nilma Goes da. Ensino de língua portuguesa: ecos de um discurso. 1997. 149 f. Dissertação (Mestrado em Educação) - Universidade Federal de Sergipe, São Cristóvão/SE.

FORQUIN, Jean-Claude. Saberes escolares, imperativos didáticos e dinâmicas sociais. Tradução de Tomaz Tadeu da Silva. Teoria \& educação, Porto Alegre, n. 5, p. 28-49, 1992.

FOUCAULT, Michel. A ordem do discurso: aula inaugural no Collège de France, pronunciada em 2 de dezembro de 1970. Tradução de Laura Fraga de Almeida Sampaio. 8. ed. São Paulo: Edições Loyola, 2002. Veja, 2006.

O que é um autor? Tradução de Antonio Fernando Cascais e Eduardo Cordeiro. Lisboa: Nova .A arqueologia do saber. 7. ed. 3. reimp. Rio de Janeiro: Forense Universitária, 2008.

FRANCHI, Carlos. Linguagem: atividade constitutiva. Almanaque, Cadernos de Literatura e Ensaio, São Paulo, Brasiliense, n. 5, p. 9-27, 1977. 1988.

. Criatividade e gramática. São Paulo: CENP/Secretaria de Educação do Estado de São Paulo,

. Prefácio. In: GERALDI, João Wanderley. Portos de passagem. São Paulo: Martins Fontes, 1991. p. IX-XIV.

FREIRE, Paulo. O professor: um profissional para si. In: GERALDI, João Wanderley; NOGUEIRA, Adriano. Paulo Freire: trabalho, comentário, reflexão. Petrópolis: Vozes, 1990. p. 38-46. 2003.

. A importância do ato de ler: em três artigos que se completam. 45. ed. São Paulo; Cortez,

GALAN, Maria Raquel Aparecida Coelho. A construção cotidiana de uma proposta de ensino: as falas de professores e alunos de LP do oeste do Paraná. 1991. 139 f. Dissertação (Mestrado em Letras - Lingüística) - Universidade Federal de Santa Catarina, Florianópolis. 
GERALDI, João Wanderley. Subsídios metodológicos para o ensino de língua portuguesa: 5a. a 8a. séries. Cadernos da FIDENE, Ijuí, n. 18, p. 70, 1981. (2. ed., 1984)

. (Org.). O texto na sala de aula: leitura \& produção. Cascavel: Assoeste, 1984.

. Aprende-se a escrever escrevendo. Signo, Santa Cruz do Sul, ano 10, n. 16, p. 27-31, 1985. 23-29, 1986a.

Prática de produção de textos na escola. Trabalhos em lingüística aplicada, Campinas, n. 7, p.

. De como produzir milagres ou o professor pega um boizinho, rifa e compra livros. In: CONGRESSO DE LEITURA DO BRASIL, 5., 1986, Campinas. Comunicações oficiais: anais. Campinas: ALB, 1986b. p. 43-50.

. Método se baseia na produção de textos. Folha de S. Paulo, São Paulo, n. ?, p. A-13, 9 set. 1987a. Entrevista.

. Livro didático de língua portuguesa: a favor ou contra? Leitura: teoria \& prática, Campinas, n. 9, p.4-7, jun. 1987b. Entrevista. (Entrevistador: Ezequiel Teodoro da Silva) 1988a.

. A leitura na sala de aula: as muitas faces de um leitor. Idéias, São Paulo, n. 5, p. 79-84,

Cinco questões sobre a questão dos métodos. In: CONGRESSO DE LEITURA DO BRASIL, 6., 1988, Campinas. Conferências e mesas-redondas: anais. Campinas: ALB, 1988b. p. 81-85.

. Educação e linguagem. Leitura: teoria \& prática, Campinas, ano 8, n. 14, p. 37-39, 1989a. $1989 b$.

. Texto: um problema para o exercício da capatazia. Contexto \& educação, Ijuí, n. 16, p. 79-85,

. Portos de passagem. São Paulo: Martins Fontes, 1991a.

. Linguagem e ação. In: SCOZ, Beatriz Judith Lima et al. Psicopedagogia: contextualização, formação e atuação profissional. Porto Alegre: Artes Médicas, 1991b. p. 19-25. 1992a.

A constituição do sujeito leitor. Revista de educação, APEOESP, São Paulo, n. 7, p. 26-27,

.Ainda e sempre: leitura. In: CONGRESSO DE LEITURA DO BRASIL, 8., 1992, Campinas. Leitura: autonomia, trabalho e cidadania: anais. Campinas: ALB, 1992b. p. 195-198.

.Portos de passagem. São Paulo: Martins Fontes, 1991. 252 p. Resenha de: FISCHER, Rosa Maria Bueno. Em aberto, Brasília, ano 10, n. 52, p. 69-72, 1992.

. Português: o aprendizado que vem da vida do próprio aluno. Nova escola, São Paulo, n. 78, p. 10-17, set. 1994.

. Memorial: 1946 - 1994. 1995. 58 f. Memorial (Concurso de Livre Docência) - Instituto de Estudos da Linguagem, Universidade Estadual de Campinas, Campinas. Não- publicado.

Letras, 1996a.

Linguagem e ensino: exercícios de militância e divulgação. Campinas: ALB/Mercado de 
Em defesa do acesso ao mundo da escrita. Proleitura, Unesp/Uem/Uel, Assis, p. 1-2, abr. 1996b. Entrevista.

. (Org.). O texto na sala de aula. São Paulo: Ática, 1997a.

. Da produção do texto escolar. In: JORNADA NACIONAL DE LITERATURA, 5., 1997, Passo Fundo. Anais... Passo Fundo: [s. n.], 1997b. p. 223-226.

. Memorial: janeiro de 1995 a abril de 1999. 1999a. 23 f. Memorial (Promoção a professor adjunto por avaliação de mérito) - Instituto de Estudos da Linguagem, Universidade Estadual de Campinas, Campinas. Não-publicado.

. Da sala de aula à construção externa da aula. In: ZACCUR, Edwiges. A magia da linguagem. Rio de Janeiro: DP\&A, 1999b. p. 123-140.

$2000 \mathrm{a}$.

. Palavras escritas, indícios de palavras ditas. Quaestio, São Paulo, ano 2, n. 2, p. 9-20, nov.

. Sobre a constituição dos objetos de ensino em língua materna. In: COLÓQUIO SOBRE QUESTÕES CURRICULARES, 4., 2000. Braga. Políticas curriculares: caminhos da flexibilização e integração: actas. Universidade do Minho (Braga): Centro de Estudos em Educação e Psicologia, 2000b. p. 369-378.

. Memorial: maio de 1999 a abril de 2002. 2002. 34 f. Memorial (Promoção a professor titular por avaliação de mérito) - Instituto de Estudos da Linguagem, Universidade Estadual de Campinas, Campinas. Não-publicado.

Convívio paradoxal com o ensino da leitura e escrita. In: ALBANO, Eleonora et al. Saudades da língua. Campinas: Mercado de Letras, 2003. p. 663-684.

Entrevista [24/06/2004]. Entrevistadora: Luzia de Fátima Paula. Campinas: Universidade Estadual de Campinas, 2004a. 1 fita cassete (30 min). Não-publicada.

. Apresentação. In: VOESE, Ingo. Análise do Discurso e o ensino de língua portuguesa. São Paulo: Cortez Editora, 2004b, p. 9-13. $2004 \mathrm{c}$.

. A aula como acontecimento. Aveiro/Portugal: Universidade de Aveiro, Campus de Santiago,

(Org.). O texto na sala de aula. São Paulo: Ática, 2005a.

(Org.). O texto na sala de aula. São Paulo: Ática, 2005b. 136 p. (Primeira orelha por Valdir Heitor Barzotto).

. (Org.). O texto na sala de aula. São Paulo: Ática, 2005c. 136 p. (Primeira orelha por Marinalva Barbosa). Hessel).

(Org.). O texto na sala de aula. São Paulo: Ática, 2005d. 136 p. (Primeira orelha por Rosa Possenti).

(Org.). O texto na sala de aula. São Paulo: Ática, 2005e. 136 p. (Segunda orelha por Sírio . (Org.). O texto na sala de aula. São Paulo: Ática, 2005f. 136 p. (Segunda orelha por Norma Shirakura). 
Um bom professor ensina a perguntar. Letra A, Belo Horizonte, ano 2, n. 6, p. 10-12, abr./maio 2006a. Entrevista.

É possível investir nas enunciações, sem as garantias dos enunciados já firmados? In: MIOTELLO, Valdemir et al. Veredas bakhtinianas: de objetos a sujeitos. São Carlos: Pedro \& João Editores, 2006b. p. 129-139.

A presença do texto na sala de aula. In: LARA, Gláucia Muniz Proença. (Org.). Língua(gem), texto, discurso: entre a reflexão e a prática. Rio de Janeiro: Lucerna; Belo Horizonte: FALE/UFMG, 2006c. p. 13-29. v. 1.

. Há funções para o ensino escolar da gramática? Discutindo Língua Portuguesa, São Paulo, v. 1, p. 28-33, 2006d.

.Leitura: uma oferta de contrapalavras. In: MIOTELLO, Valdemir et al. O espelho de Bakhtin. São Carlos: Pedro \& João Editores, 2007. p. 39-46.

Ingo Voese: notas biográficas \& lembranças de convívio. Signo, Santa Cruz do Sul, v. 33, p. 14-22, 2008a.

. Ler e escrever: uma mera exigência escolar? In: BRAGANÇA, Inês F. S.; ARAUJO, Mairce S.; ALVARENGA, Marcia S.; MAURÍCIO, Lúcia V. (Orgs.). Vozes da educação: memórias, histórias e formação de professores. Rio de Janeiro: DP\&A, 2008b. p. 123-134.

.Os pecados da Lingüística. Palavras, APP, Lisboa, 2008c. Entrevista.

.Entrevista [05/09/2008]. Núcleo de Estudos e Pesquisas da Educação na Pequena Infância (NUPEIN), Centro de Ciências da Educação, Universidade Federal de Santa Catarina, 2008d. (Entrevistadoras: Márcia Buss Simão, Pricilla C. Trierweiller e Rosinete Schmitt). On-line.

Correlações entre as situações políticas e as preocupações com a língua portuguesa. In: CINTRA, Anna Maria Marques. (Org.). Ensino de língua portuguesa: reflexão e ação. São Paulo: EDUC, 2008e, p. 13-34.

GERALDI, João Wanderley; ABAURRE, Maria Bernadete; SABINSON, Maria Laura Trindade Mayrink; FIAD, Raquel Salek. Considerações sobre a utilização de um paradigma indiciário na análise de episódios de refacção textual. Trabalhos em lingüistica aplicada, Campinas, n. 25, p. 5-23, 1995.

GERALDI, João Wanderley; CHIAPPINI, Lígia; MICHELETTI, Guaraciaba; CITELLI, Adilson. A circulação de textos na escola: primeiros resultados. In: ESTUDOS LINGÜÍSTICOS, 24., 1995, São Paulo. Seminários do grupo de estudos lingüísticos: anais. São Paulo, 1995. p. 42-49.

GERALDI, João Wanderley; COLLARES, Cecília Azevedo Lima; MOYSÉS, Maria Aparecida Affonso. As aventuras do conhecer: da transmissão à interlocução. Educação \& sociedade, Campinas, ano 23, n. 78, p. 91-116, abr. 2002.

GERALDI, João Wanderley; FIAD, Raquel Salek; SILVA, Lílian Lopes Martin da. Para repensar o ensino de português. Jornal da UNICAMP, Campinas, ano 3, n. 29, p. 4, mar.1989. Entrevista.

GERALDI, João Wanderley; GERALDI, Corinta; CARBÓ, Victoria; MAUCH, Carla; GONZÁLEZ, Tomás; GONZÁLEZ, Vera; GONZÁLEZ, Fernando; LARROSA, Miréia; LARROSA, Jorge. Roda de conversa: leitura e escrita na escola podem ser livres? Presença pedagógica, Belo Horizonte, v.11, p. 5-19, nov./dez. 2005. Entrevista. 
GERALDI, João Wanderley; SILVA, Lilian Lopes Martins da; MOYSÉS, Sarita; FIAD, Raquel Salek. O ensino de língua portuguesa no $1^{\circ}$. grau: projeto magistério. São Paulo: Atual, 1986.

GERALDI, João Wanderley; SILVA, Lilian Lopes Martin da; FIAD, Raquel Salek. Lingüística, ensino de língua materna e formação de professores. D.E.L.T.A, São Paulo, v. 12, n. 2, p. 307-326, 1996.

GERALDI, João Wanderley; RUIZ, Eliana M.; FIAD, Raquel Salek; SILVA, Lilian Lopes Martin. O livro didático de língua portuguesa: didatização e destruição da atividade lingüística. Trabalhos em lingüistica aplicada, Campinas, n. 7, p. 81-86, 1986.

. A destruidora didática dos livros. Leia, São Paulo, n.?, p. 41-43, mar. 1986.

GNERRE, Maurizzio. Linguagem e poder. In: Subsídios à proposta curricular de Língua Portuguesa para o $2^{\circ}$ grau: variação lingüística e ensino da língua materna. Secretaria de Estado da Educação, São Paulo, 1978. v. IV.

Linguagem, escrita e poder. São Paulo: Martins Fontes, 1985.

GONÇALVES, Rodrigo Tadeu. Perpétua prisão órfica ou Ênio tinha três corações: o relativismo lingüístico e o aspecto criativo da linguagem. 2008. 240 f. Tese (Doutorado em Lingüística) - Setor de Ciências Humanas, Letras e Arte. Universidade Federal do Paraná, Curitiba.

GHIRALDELLI JUNIOR, Paulo. História da educação. 2. ed. rev. São Paulo: Cortez, 1994.

GREGOLIN, Maria do Rosário Valencise. Olhares oblíquos sobre o sentido do discurso. Apresentação. In: GREGOLIN, Maria do Rosário Valencise; BARONAS, Roberto. (Orgs.). Análise do discurso: as materialidades do sentido. 2. ed. São Carlos: Editora Claraluz, 2003. p. 7-16.

GUIMARÃES, Eduardo. Os limites do sentido: um estudo histórico e enunciativo da linguagem. Campinas: Pontes, 1995.

GUIMARÃES, Elisa. O ensino de língua portuguesa na memória da escola brasileira: aspectos da história de uma disciplina. In: GÄRTNER, Eberhard; HUNDT, Christine; SCHÖNBERGER. (Eds.) Estudos sobre o ensino da língua portuguesa. Frankfurt am Main: TFM, 1999. p. 15-26.

HÉBRARD, Jean. Três figuras de jovens leitores: alfabetização e escolarização do ponto de vista da História Cultural. Tradução de Christian Pierre Kasper. In: ABREU, Márcia. (Org.). Leitura, história e história da leitura. 1. reimp. Campinas: Mercado de Letras: Associação de Leitura do Brasil; São Paulo: FAPESP, 2002. p.33-77.

IEL. Notas sobre a UNICAMP e o IEL, 1982.

ILARI, Rodolfo. A lingüistica e o ensino da língua portuguesa. São Paulo: Martins Fontes, 1985.

. Para um novo perfil do professor de português. In: ESTUDOS LINGÜÍSTICOS, 12., 1986, Lins. Seminários do grupo de estudos lingüísticos: anais. Lins: GEL, 1986. p. 303-309.

.Alguns problemas semânticos na análise dos adjetivos. Cadernos de estudos lingüisticos, Campinas, n. 24, p. 41-45, 1993.

. "Seu Carlos", um amigo de 40 anos. Jornal da UNICAMP, Campinas, ano 15, n. 166, p. 2, set. 2001. Entrevista. (Caderno temático em homenagem a Carlos Franchi). 
JAKOBSON, Roman. Prefácio. BAKHTIN, Mikhail. Marxismo e filosofia da linguagem. Tradução de Michel Lahud e Yara F. Vieira. 10. ed. São Paulo: HUCITEC, 2002.

KHUN, Thomas S. A estrutura das revoluções científicas. Tradução de Beatriz Vianna Boeira e Nelson Boeira. São Paulo: Editora Perspectiva, 1982.

KRISTEVA, Julia. História da linguagem. Tradução de Maria Margarida Barahona. Lisboa: Edições 70, 1969.

LAGAZZI-RODRIGUES, Suzy. A língua portuguesa no processo de institucionalização da lingüística. In: ORLANDI, Eni Pulcinelli; GUIMARÃES, Eduardo. (Orgs.). Institucionalização dos estudos da linguagem: a disciplinarização das idéias lingüísticas. Campinas: Pontes, 2002. p. 13-22.

LAJOLO, Marisa. O que é literatura. São Paulo: Brasiliense, 1982.

LEROY, Maurice. As grandes correntes da Lingüistica Moderna. Tradução de Izidoro Blikstein, José Paulo Paes e Frederico Pessoa de Barros. São Paulo: Cultrix, 1971.

LIMA, Jorge de. Melhores poemas de Jorge de Lima. São Paulo: Global Editora, 1994.

MAGNANI, Maria do Rosário Mortatti. Em sobressaltos: formação de professora. Campinas: Ed. UNICAMP, 1993.

. Prefácio à $2^{\mathrm{a}}$. edição. In: MAGNANI, Maria do Rosário Mortatti. Em sobressaltos: formação de professora. Campinas: Ed. UNICAMP, 2001. p. XIII-XIX.

MAINGUENEAU, Dominique. Novas tendências em análise do discurso. Tradução de Freda Indursky. 3.ed. Campinas: Pontes, 1997.

MARINHO, Marildes. A oficialização de novas concepções para o ensino de português no Brasil. 2001. 301 f. Tese (Doutorado em Lingüística) - Instituto de Estudos da Linguagem, Universidade Estadual de Campinas, Campinas.

MAYRINK-SABINSON, Maria Laura Trindade. A produção escrita da criança e sua avaliação. Cadernos de estudos lingüisticos, Campinas, n. 24, p. 19-33, 1993.

MORTATTI, Maria do Rosário Longo. Notas sobre linguagem, texto e pesquisa histórica em educação. História da Educação, Pelotas, n. 6, p. 69-77, out. 1999a.

. Uma proposta para o próximo milênio: o pensamento interacionista sobre alfabetização. Presença pedagógica, Belo Horizonte, v. 5, n. 29, p. 21-27, set./out. 1999 b.

. Os sentidos da alfabetização (São Paulo - 1876/1994). São Paulo: Ed. Unesp; Brasília: MEC/INEP/COMPED, 2000.

. Ensino de língua e literatura no Brasil: repertório documental republicano. Marília: FFC/UNESP, 2003. (digitado).

O DEPARTAMENTO de Lingüística do Instituto de Estudos da Linguagem. Cadernos de estudos lingüisticos, n. 1, p. 83-91, 1978.

ORLANDI, Eni Pulcinelli. A produção da leitura e suas condições. Leitura: teoria \& prática, Campinas, ano 2, n. 1, p. 20-25, 1983. 
. As histórias das leituras. Leitura: teoria \& prática, Campinas, ano 3, n. 3, p. 7-9, 1984.

. Apresentação. In: PÊCHEUX, Michel. $O$ discurso: estrutura ou acontecimento. Tradução de Eni Pulcinelli Orlandi. Campinas: Fontes, 1990.

. Análise de discurso. Campinas: Pontes, 1999a.

. O que é lingüistica. São Paulo: Brasiliense, 1999b.

ORLANDI, Eni Pulcinelli; GUIMARÃES, Eduardo. Formação de um espaço de produção lingüística: a gramática no Brasil. In: ORLANDI, Eni Pulcinelli. (Org.). História das idéias lingüisticas: construção do saber metalingüístico e constituição da língua nacional. Campinas: Pontes; Cáceres: UNEMAT Editora, 2001. p. 21-38.

OSAKABE, Haquira. Considerações em torno do acesso ao mundo da escrita. In: ZILBERMAN, Regina. (Org.). A leitura em crise na escola. Porto Alegre: Mercado Aberto, 1982. p. 147-152.

PALMA FILHO, João Cardoso. Reorganização do ensino fundamental na rede estadual de ensino paulista, política e ideologia: memórias. In: PALMA FILHO, João Cardoso; ALVES, Maria Leila Alves; DURAN, Marília Claret Geraes. Ciclo básico em São Paulo: memórias da Educação nos anos 1980. São Paulo: Xamã, 2003.

PAULA, Luzia de Fátima. O ensino de língua portuguesa no Brasil, segundo João Wanderley Geraldi. 2004a. 144 f. Dissertação (Mestrado em Educação) - Faculdade de Filosofia e Ciências, Universidade Estadual Paulista, Marília.

Bibliografia de e sobre João Wanderley Geraldi: um instrumento de pesquisa. $16 \mathrm{f}$. Instrumento de pesquisa, 2004b.

. Bibliografia de e sobre J. W. Geraldi: um instrumento de pesquisa. $27 \mathrm{f}$. Instrumento de pesquisa, 2009a.

. Referências de textos citados por J. W. Geraldi em textos que tematizam o ensino de língua portuguesa: um instrumento de pesquisa. $16 \mathrm{f}$. Instrumento de pesquisa, $2009 \mathrm{~b}$.

. Formação acadêmica de J. W. Geraldi: um instrumento de pesquisa. 14 f. Instrumento de pesquisa, 2009c.

PÊCHEUX, Michel. O discurso: estrutura ou acontecimento. Tradução de Eni Pulcinelli Orlandi. Campinas: Fontes, 1990.

PIVOVAR, Altair . Leitura e Escrita: a captura de um objeto de ensino. 1999. 142 f. Dissertação (Mestrado em Letras) - Universidade Federal do Paraná, Curitiba.

POSSENTI, Sírio. Por que (não) ensinar gramática na escola. Campinas: Mercado de Letras; Associação de Leitura do Brasil, 1996.

PRADO, Guilherme do Val Toledo. Documentos desemboscados: conflito entre o gênero do discurso e a concepção de linguagem nos documentos curriculares de ensino de língua portuguesa. 1999. 169 f. Tese (Doutorado em Lingüística Aplicada) - Instituto de Estudos da Linguagem, Universidade Estadual de Campinas, Campinas.

Processo $n^{\circ}$. 2965/72 - Reconhecimento dos cursos de bacharelado de Ciências Sociais, de Economia e de Lingǘstica ministrados pelo IFCH, volume I, 1972. 
Processo $n^{o}$. 2965/72 - Reconhecimento dos cursos de bacharelado de Ciências Sociais, de Economia e de Lingüística ministrados pelo IFCH, volume II, 1972.

Processo n. 7968/76 - Constituição do Instituto de Estudos da Linguagem, 1976.

RAZZINI, Marcia de Paula Gregorio. Antologia nacional (1985-1969): museu literário ou doutrina? 1992. 123 f. Dissertação (Mestrado em Teoria Literária) - Instituto de Estudos da Linguagem, Universidade Estadual de Campinas, Campinas.

O espelho da nação: a Antologia nacional e o ensino de português e de literatura (18381971). 2000. 442 f. Tese (Doutorado em Teoria Literária) - Instituto de Estudos da Linguagem, Universidade Estadual de Campinas, Campinas.

ROJO, Roxane Helena R.; CORDEIRO, Glaís Sales. Apresentação. In: SCHNEUWLY, Bernard; DOLZ, Joaquim. Gêneros orais e escritos na escola. Tradução e organização de Roxane Rojo e Glaís Sales Cordeiro. Campinas: Mercado de Letras, 2004.

ROJO, Roxane H. R. O texto no ensino-aprendizagem de línguas hoje: desafios da contemporaneidade. In: TRAVAGLIA, L. C.; FINOTTI, L. H. B.; MESQUITA, E. M. C. (Orgs.). Gêneros de texto: caracterização e ensino. Uberlândia/MG: Editora da Universidade Federal de Uberlândia (EDUFU), 2008. p. 09-43.

RUSSEL, Bertrand. História do pensamento ocidental: a aventura dos pré-socráticos a Wittgenstein. Tradução de Laura Alves e Aurélio Rebello. Rio de Janeiro: Ediouro, 2002.

SÁ, Maria Helena de Araújo e. Apresentação. In: GERALDI, João Wanderley. A aula como acontecimento. Aveiro/Portugal: Universidade de Aveiro, Campus de Santiago, 2004. 21 p.

SANTOS, Luciola Licinio de C. P. História das disciplinas escolares: perspectivas de análise. Teoria \& educação, Porto Alegre, n. 2, p. 21-29, 1990.

SAVIANI, Dermeval. Ensaios contra-hegemônicos: as pedagogias críticas buscando orientar a prática educativa (1980-1991). In: SAVIANI, Dermeval. História das idéias pedagógicas no Brasil. 2. ed. rev. e ampl. Campinas: Autores Associados, 2008. p. 401-424.

SILVA, Lilian Lopes Martin da. Mudar o ensino de língua portuguesa: uma promessa que não venceu nem se cumpriu mas que merece ser interpretada. 1994. 350 f. Tese (Doutorado em Educação) Faculdade de Educação, Universidade Estadual de Campinas, Campinas.

SOARES, Magda. Linguagem e escola: uma perspectiva social. 4. ed. São Paulo: Ática, 1987.

. Português na escola: história de uma disciplina curricular. Revista de educação AEC, Brasília, n. 101, p. 9-26, 1996.

Português na escola: história de uma disciplina curricular. BAGNO, Marcos. (Org.). Lingüística da norma. São Paulo: Edições Loyola, 2002. p. 155-177.

SOUZA, Pedro de. Às margens da gramática, a emergência da semântica no Brasil. In: ORLANDI, Eni Pulcinelli. (Org.). História das idéias lingüísticas: construção do saber metalingüístico e constituição da língua nacional. Campinas: Pontes; Cáceres: UNEMAT Editora, 2001. p. 125-137.

TRASK, R. L. Dicionário de linguagem e lingüistica. Tradução de Rodolfo Ilari. São Paulo: Contexto, 2004.

VIGOTSKI, Lev Semionovitch. Pensamento e linguagem. Tradução de Jéferson Luiz Camargo. São Paulo: Martins Fontes, 1994. 
VOGT, Carlos Alberto. Oswald Ducrot e a UNICAMP: uma visão pessoal. Cadernos de estudos lingüísticos, Campinas, n. 35, p. 9-16, 1998.

ZILBERMAN, Regina. (Org.). A leitura em crise na escola. Porto Alegre: Mercado Aberto, 1982. 


\section{Obras de referência citadas}

ASSOCIAÇÃO BRASILEIRA DE NORMAS TÉCNICAS. NBR 6023: informação e documentação: referências: elaboração. Rio de Janeiro, 2002.

NBR 10520: informação e documentação: citações em documentos: apresentação. Rio de Janeiro, 2002.

. NBR 14724: informação e documentação: trabalhos acadêmicos: apresentação. Rio de Janeiro, 2002.

CHARAUDEAU, Patrick; MAINGUENEAU; Patrick. Dicionário de análise do discurso. Tradução de Fabiana Komesu. São Paulo: Contexto, 2004.

DUBOIS, Jean et al. Dicionário de lingüística. Tradução de Frederico Pessoa de Barros et al. São Paulo: Cultrix, 1978.

DUCROT, Oswald; TODOROV, Tzvetan. Dicionário enciclopédico das ciências da linguagem. Tradução de Alice Kyoko Miyashiro, J. Guinsburg, Mary Amazonas Leite de Barros e Geraldo Gerson de Souza. 2. ed. São Paulo: Perspectiva, 1972.

HOUAISS, Antonio; VILlAR, Mauro de Salles. Dicionário Houaiss da Língua Portuguesa. Rio de Janeiro: Objetiva, 2001.

MAINGUENEAU, Dominique; CHARAUDEAU, Patrick. Tradução de Fabiana Komesu. Dicionário de Análise do Discurso. São Paulo: Contexto, 2004.

TRASK, R. L. Dicionário de linguagem e lingüística. Tradução de Rodolfo Ilari. São Paulo: Contexto, 2004.

XAVIER, Maria Francisca; MATEUS, Maria Helena. (Orgs.). Dicionário de termos lingüísticos. Lisboa: Cosmos, 1990.

UNIVERSIDADE ESTADUAL PAULISTA. Normas para publicações da Unesp: artigos de publicações periódicas. São Paulo, 1994. v. 1. 
APÊNDICE A

Bibliografia de e sobre J. W. Geraldi:

um instrumento de pesquisa 
LUZIA DE FÁTIMA PAULA

BIBLIOGRAFIA DE E SOBRE J. W. GERALDI:

UM INSTRUMENTO DE PESQUISA

Universidade Estadual Paulista

Faculdade de Filosofia e Ciências

Campus de Marília

Marília - SP

Dezembro de 2009 
SUMÁRIO

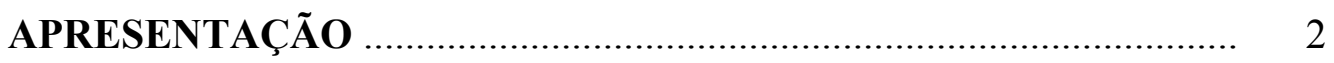

1. BIBLIOGRAFIA DE J. W. GERALDI ........................................... 6

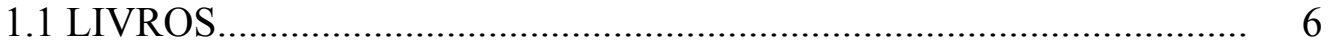

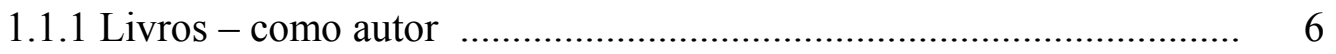

1.1.2 Livros - como organizador/coordenador......................................... 6

1.1.3 Livros - como co-autor............................................................... 6

1.2 CAPÍTULOS DE LIVROS …….................................................... 7

1.2.1 Capítulos de livros - como autor ...................................................... 7

1.2.2 Capítulos de livros - como co-autor.................................................. 9

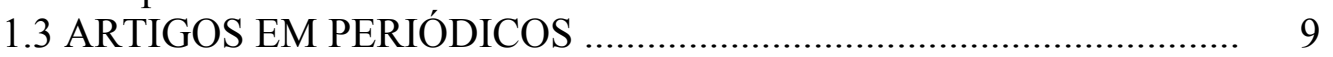

1.3.1 Artigos em periódicos - como autor ................................................ 9

1.3.2 Artigos em periódicos - como co-autor .......................................... 12

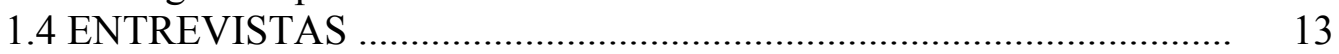

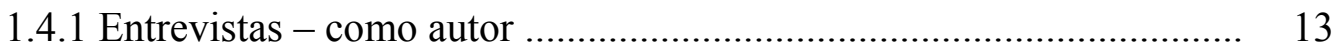

1.4.2 Entrevistas - como co-autor ......................................................... 14

1.5 TEXTOS EM ANAIS DE EVENTOS ............................................... 14

1.5.1 Textos em anais de eventos - como autor ....................................... 14

1.5.2 Textos em anais de eventos - como co-autor .................................... 16

1.6 ARTIGOS EM JORNAIS DE NOTÍCIAS ...................................... 16

1.6.1 Artigos em jornais de notícias - como autor .................................... 16

1.6.2 Artigos em jornais de notícias - como co-autor ............................... 16

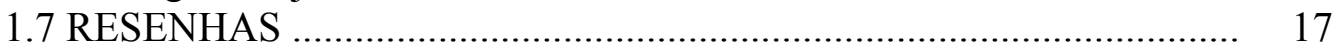

1.7.1 Resenhas - como autor ........................................................... 17

1.7.2 Resenhas - como co-autor........................................................... 17

1.8 PREFÁCIOS E APRESENTAÇÕES DE LIVROS ............................. 17

1.9 QUARTA CAPA E ORELHAS DE LIVROS ...................................... 19

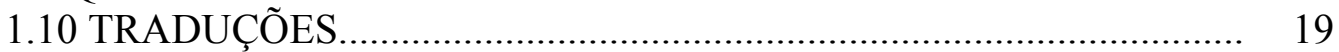

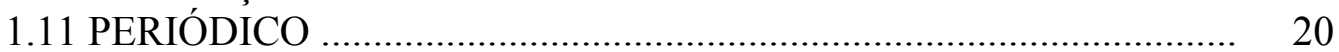

1.12 DISSERTAÇÃO, TESES E MEMORIAIS ACADÊMICOS ............... 20

1.13 VÍDEOS ........................................................................... 21

2. BIBLIOGRAFIA SOBRE J. W. GERALDI................................. 22

2.1 CAPÍTULOS DE LIVROS............................................................... 22

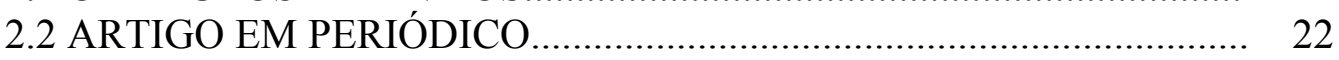

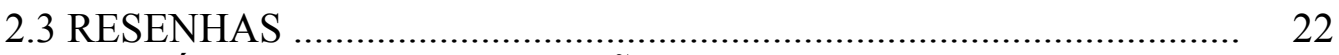

2.4 PREFÁCIOS E APRESENTAÇÕES................................................. 22

2.5 ORELHAS DE LIVROS .................................................................... 23

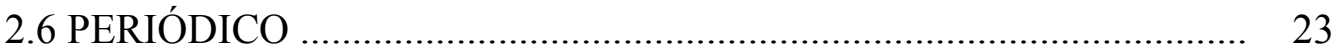

2.7 DISSERTAÇÕES E TESES ............................................................. 23

Instituições, acervos e catálogos digitais e bases de dados de 25 bibliotecas universitárias disponíveis on-line consultados 


\section{APRESENTAÇ̃̃O}

Para a elaboração deste instrumento de pesquisa, utilizei os procedimentos de localização, recuperação, reunião, seleção e ordenação da bibliografia de e sobre J. W. Geraldi, responsável pelo pioneirismo do interacionismo linguístico aplicado ao ensino de língua portuguesa no Brasil, a partir da utilização do texto na sala de aula, focalizando as três práticas para esse trabalho em sala de aula: leitura, produção e análise linguística.

O trabalho de Geraldi sobre o ensino de língua portuguesa iniciou-se em 1978 e tem continuidade ainda nos dias atuais. As referências dos textos por mim localizados foram produzidos por Geraldi entre 1978, ano do primeiro texto publicado pelo autor, e 2008, ano determinado para o encerramento da recuperação dos documentos para a pesquisa de que resultou este instrumento de pesquisa.

É importante ressaltar que o total de referências de textos de Geraldi contido neste instrumento de pesquisa inclui apenas a primeira edição de cada título publicado, contando novamente a referência do texto quando o mesmo título é publicado sob outro tipo de texto ou em outro periódico.

Os primeiros textos de Geraldi, publicados em 1978, são: um artigo em periódico, "Algumas observações sobre o estudo da significação"; um texto em anais de eventos, "Orientação argumentativa e pressuposição", e a dissertação de mestrado intitulada Se a semântica fosse também pragmática... ou para uma análise semântica dos enunciados condicionais.

E são doze os seus textos mais recentes, publicados em 2008: cinco como: capítulos de livros; dois como artigos em periódicos; quatro como entrevistas; e um como apresentação. Como capítulos de livro, foram publicados os seguintes textos: "A formação de jovens diante das exigências do mercado de trabalho", em Perspectivas e propostas na formação para o mundo do trabalho, organizado pela Comissão de Educação e Cultura da Câmara dos Deputados, publicado pela Câmara dos Deputados (Brasília/DF); “Texto e discurso: questões epistemológicas para a Lingüística", no livro Sentidos em movimento: identidade e argumentação, organizado por Maria Flávia Figueiredo, Marina Célia Mendonça e Vera Lúcia Rodella Abriata, pela Editora da Universidade de Franca (UNIFRAN) (Franca/SP); "Ler e escrever: uma mera exigência escolar?", no livro Vozes da educação: memórias, histórias e formação de professores, organizado por Inês F. S. Bragança, Mairce S. Araújo, Marcia S. Alvarenga e Lúcia V. Maurício, publicado pela DP\&A (Rio de Janeiro/RJ); “Correlações entre as situações políticas e as preocupações com a língua portuguesa”, no livro Ensino de língua portuguesa: reflexão e ação, organizado por Anna Maria Marques Cintra, pela Editora 
da Pontifícia Universidade Católica de São Paulo (EDUC) (São Paulo/SP); “A infatigável tarefa de frear a língua", no livro Os desafios da língua: pesquisas em língua falada e escrita, organizado por Denilda Moura, pela Editora da Universidade Federal de Alagoas (EDUFAL) (Maceió-AL).

Como artigos em periódicos, no ano de 2008, foram publicados os textos: "Ingo Voese: notas biográficas \& lembranças de convívio" e "Construção de uma compreensão", ambos em Signo (Santa Cruz do Sul-RS). Ainda em 2008, foram publicadas quatro entrevistas de Geraldi: "Leitura: atividade humana e não apenas escolar", pela Universidade Potiguar (Natal-RN); "Professor não pode ter medo de errar", pelo Centro de Estudos e Pesquisas em Educação, Cultura e Ação Comunitária (CENPEC) (São Paulo-SP); “Os pecados da Lingüística", por Palavras (Lisboa-Portugal); uma entrevista intitulada "Entrevista", publicada pelo Núcleo de Estudos e Pesquisas da Educação na Pequena Infância (NUPEIN), Centro de Ciências da Educação, da Universidade Federal de Santa Catarina (UFSC) (Florianópolis/SC); e uma apresentação ao livro A revolução bakhtiniana: o pensamento de Bakhtin e a ideologia contemporânea, de Augusto Ponzio, traduzido para a língua portuguesa sob a coordenação de Valdemir Miotello, André Luiz Covre, Fabrício César de Oliveira, Diego Aparecido Alves Gomes Figueira, Dionísio da Silva Pimenta, Kátia Vanessa Tarantini Silvestre, Pedro Guilherme Orzari Bombonato, Rômulo Augusto Orlandini, Sandra Mara Azevedo, Aline Maria Pacífico Manfrim, Carlos Alberto Turati, Ivo Di Camargo Jr e Sidney de Paulo, publicado pela Contexto (São Paulo-SP).

Para a realização deste instrumento de pesquisa, tomei por base o instrumento de pesquisa anteriormente realizado, para fins de pesquisa de mestrado ${ }^{177}$, intitulado Bibliografia de e sobre João Wanderley Geraldi: um instrumento de pesquisa (PAULA, 2004b), tendo por finalidade atualizar a bibliografia de e sobre Geraldi, focalizada no instrumento de pesquisa anterior.

Para o instrumento de pesquisa realizado em nível de mestrado, foram localizadas, recuperadas, reunidas, selecionadas e ordenadas 141 referências de textos de Geraldi. Para este instrumento de pesquisa, até o presente momento foram localizadas 224 referências de textos de Geraldi, produzidos no período compreendido entre 1978 e 2008, resultando em 80 novos textos, publicados de 2002, ano determinado para o encerramento da recuperação dos

\footnotetext{
177 A saber: PAULA, Luzia de Fátima. O ensino de língua portuguesa no Brasil, segundo João Wanderley Geraldi. 2004. 144 f. Dissertação (Mestrado em Educação) - Faculdade de Filosofia e Ciências, Universidade Estadual Paulista, Marília.
} 
documentos para a pesquisa de mestrado, a 2008, ano delimitado para o encerramento desta pesquisa, resultando, portanto, em 80 novos textos em seis anos de trabalho de Geraldi.

Como pode ser observado no Quadro 1, essas referências distribuem-se em: livros (como autor, organizador ou coordenador, co-autor): 15; capítulos de livros (como autor, coautor): 31; artigos em periódicos (como autor, co-autor): 64; entrevistas (como autor; como co-autor): 24; textos em anais de eventos (como autor; como co-autor): 22; artigos em jornais (como autor; como co-autor): 4; resenhas: 9; prefácios e apresentações de livros: 22; quarta capa e orelhas de livros: 5; traduções: 12; periódico: 1; dissertação, teses e memoriais acadêmicos: 6; e vídeos: 9 .

\section{Quadro 1 - Bibliografia de J. W. Geraldi, por tipo de texto e forma de participação ${ }^{178}$}

\begin{tabular}{|l|c|}
\hline \multicolumn{1}{|c|}{ TIPO DE TEXTO } & QUANTIDADE \\
\hline Livros & 15 \\
\hline Capítulos de livros & 31 \\
\hline Artigos em periódicos & 64 \\
\hline Entrevistas & 24 \\
\hline Textos em anais de eventos & 22 \\
\hline Artigos em jornais de notícias & 4 \\
\hline Resenhas & 9 \\
\hline Prefácios e apresentações de livros & 22 \\
\hline Quarta capa e orelhas de livros & 5 \\
\hline Traduções & 12 \\
\hline Periódico & 1 \\
\hline Dissertação, teses e memoriais acadêmicos & 6 \\
\hline Vídeos & 9 \\
\hline TOTAL & $\mathbf{2 2 4}$ \\
\hline
\end{tabular}

Da bibliografia sobre Geraldi, em pesquisa realizada para a elaboração do instrumento de pesquisa, foram localizadas, recuperadas, reunidas, selecionadas e ordenadas 28 referências de textos, de 1978, quando se iniciou a publicação de textos de Geraldi, a 2008, ano determinado para o encerramento da pesquisa.

Portanto, no período compreendido entre 1978 a 2008, foram publicados: capítulos de livros: 4; artigo em periódico: 1; resenhas: 2; prefácios e apresentações: 7; orelhas de livros: 5; periódico: 1; dissertações e teses: 8, como apresento no Quadro 2.

\footnotetext{
${ }^{178}$ Neste quadro, foram computadas apenas as primeiras edições de cada livro publicado, exceto no caso da coletânea $O$ texto na sala de aula, em que foram computadas a edição pela Assoeste e as duas edições pela Ática: $1^{\mathrm{a}}$ edição e edição comemorativa.
} 
Quadro 2 - Bibliografia sobre a obra e a atuação profissional de J. W. Geraldi, por tipo e quantidade de texto

\begin{tabular}{|l|c|}
\hline \multicolumn{1}{|c|}{ TIPO DE TEXTO } & QUANTIDADE \\
\hline Capítulos de livro & 4 \\
\hline Artigo em periódico & 1 \\
\hline Resenhas & 2 \\
\hline Prefácios e apresentações & 7 \\
\hline Orelhas de livro & 5 \\
\hline Periódico & 1 \\
\hline Dissertações e teses & 8 \\
\hline TOTAL & $\mathbf{2 8}$ \\
\hline
\end{tabular}

Para efeitos de realização da pesquisa de doutorado, consultei a bibliografia de J. W. Geraldi, os memoriais acadêmicos do autor e o seu currículo, que consta no Sistema de Currículos Lattes, assim como acervos, instituições e sites do Brasil e do exterior.

As referências dos textos de e sobre Geraldi apresentam-se a seguir em ordem cronológica de publicação, distribuídos em seções indicativas do tipo de texto e da forma de participação. 


\subsection{LIVROS}

\subsubsection{Livros - como autor}

1. GERALDI, João Wanderley. Portos de passagem. São Paulo: Martins Fontes, 1991. (2. ed., 1993;

3. ed., 1995; 4. ed. 1997).

2. GERALDI, João Wanderley. Linguagem e ensino: exercícios de militância e divulgação. Campinas: ALB/Mercado de Letras, 1996. (2. ed., 1999; 3. reimp., 2002).

3. GERALDI, João Wanderley. A aula como acontecimento. Aveiro/Portugal: Universidade de Aveiro, Campus de Santiago, 2004.

\subsubsection{Livros - como organizador/coordenador}

1. GERALDI, João Wanderley. (Org.). O texto na sala de aula: leitura \& produção. Cascavel: Assoeste, 1984. (2. ed., 1985; 3. ed., 1987; 5. ed., 1990; 7. ed., 1991).

2. GERALDI, João Wanderley. (Org.). O texto na sala de aula. São Paulo: Ática, 1997. (Segunda edição modificada). (3. ed., 1999; 3. ed./3. reimp., 2001; 3. ed./5. reimp., 2002).

3. GERALDI, João Wanderley; CITELLI, Beatriz (Coord.). Aprender e ensinar com textos de alunos. São Paulo: Cortez, 1997. (Aprender e ensinar com textos, v. 1 - Coordenadora geral: Lígia Chiappini). (Pré-edição: FFLCH/USP, 1994; Ed. Marca D'Água, 1995).

4. GERALDI, João Wanderley. (Org.). O texto na sala de aula. São Paulo: Ática, 2005. (Terceira edição modificada). (4. ed. 1. reimp., 2006).

\subsubsection{Livros - como co-autor}

1. GERALDI, João Wanderley; ORLANDI, Eni Pulcinelli; POSSENTI, Sírio; GUIMARÃES, Eduardo J.; DURIGAN, Jesus Antonio. Sobre a estruturação do discurso. Campinas: Instituto de Estudos da Linguagem/Universidade Estadual de Campinas, 1981.

2. GERALDI, João Wanderley; ILARI, Rodolfo. Semântica. São Paulo: Ática, 1985. (2. ed., 1985; 3. ed., 1987; 4. ed., 1990; 6. ed., 1994; 9. ed.,1990; 10. ed., 2002, 11. ed., 2006).

3. GERALDI, João Wanderley; SILVA, Lilian Lopes Martins da; MOYSÉS, Sarita; FIAD, Raquel Salek. O ensino de língua portuguesa no $1^{\circ}$. grau: projeto magistério. São Paulo: Atual, 1986.

4. GERALDI, João Wanderley; NOGUEIRA, Adriano. (Orgs.). Paulo Freire: trabalho, comentário, reflexão. Rio de Janeiro: Vozes, 1990.

5. GERALDI, João Wanderley; NOGUEIRA, Adriano. Paulo Freire: una reflexión sobre la educación, administración y política en el município de São Paulo, Brasil. Talca: Universidad de Talca, 1994. Tradução para língua espanhola.

6. GERALDI, João Wanderley; CORTESÃO, Luiza; NUNES, Rosa; FREIRE, Abreu; TRINDADE, Rui; ROMÃO, João Eustáquio. Diálogos através de Paulo Freire. Porto-Portugal: Edição Instituto Paulo Freire de Portugal e Centro de Recursos Paulo Freire da Faculdade de Psicologia e de Ciências da Educação (FPCE), 2004. 
7. GERALDI, João Wanderley; FICHTNER, Bernd; MALDONADO, Carlos; HAAS, Lurdi; GERALDI, Corinta Maria Grisólia; KNOBLOCH, Clemens; RIPPER, Afira V.; ZAGHETTI, Joseane; CAMERINI, Maria Florentina A.; LEIBOVICI, Sandra; BENITES, Maria; LOBO, Amauri; CESNIK, Eunice; VIDOTTI, Alessandra. Janelas para o mundo: diálogo com outras vozes. Porto Alegre: Livraria do Arquiteto, 2006.

8. GERALDI, João Wanderley; FICHTNER, Bernd; BENITES, Maria. Transgressões convergentes: Vigotski, Bakhtin, Bateson. Campinas: Mercado de Letras, 2006.

\subsection{CAPÍTULOS DE LIVROS}

\subsubsection{Capítulos de livros - como autor}

1. GERALDI, João Wanderley. Tópico-comentário e orientação argumentativa. In: ORLANDI, Eni Pulcinelli et al. Sobre a estruturação do discurso. Campinas: IEL/UNICAMP, 1981. p. 63-90.

2. GERALDI, João Wanderley. Linguagem e ação. In: SCOZ, Beatriz Judith Lima et al. Psicopedagogia: contextualização, formação e atuação profissional. Porto Alegre: Artes Médicas, 1991. p. 19-25.

3. GERALDI, João Wanderley. O professor como leitor do texto do aluno. In: MARTINS, Maria Helena (Org.). Questões de linguagem. São Paulo: Contexto, 1991. p. 47-53.

4. GERALDI, João Wanderley. Trabalho com a linguagem e história da educação na rede de ensino. In: NOGUEIRA, Adriano. Contribuições da interdisciplinaridade para a ciência, para a educação e para o trabalho sindical. Curitiba: APP-Sindicato; Petrópolis: Vozes, 1994. cap. 2, p. 45-66.

5. GERALDI, João Wanderley. Uma reflexão interdisciplinar a partir da análise lingüística de um texto produzido por um aluno. In: NOGUEIRA, Adriano. Contribuições da interdisciplinaridade para a ciência, para a educação e para o trabalho sindical. Curitiba: APP-Sindicato; Petrópolis: Vozes, 1994. cap. 3, p. 67-76.

6. GERALDI, João Wanderley. A leitura em momento de crise social. In: ABREU, Márcia. Leituras no Brasil. Campinas: ALB/Mercado de Letras, 1995. p. 179-192.

7. GERALDI, João Wanderley. Paulo Freire: narrador e pensador. In: BARZOTTO, Valdir Heitor. Estado de leitura. Campinas: ALB/Mercado de Letras, 1999. p. 207-215.

8. GERALDI, João Wanderley. Professor, militante e pensador. In: AGUIAR, Flávio. Antonio Candido: pensamento e militância. São Paulo: Ed. Fundação Perseu Abramo; São Paulo: Humanitas/FFLCH/USP, 1999. p.19-20.

9. GERALDI, João Wanderley. Da sala de aula à construção externa da aula. In: ZACCUR, Edwiges. A magia da linguagem. Rio de Janeiro: DP\&A, 1999. p. 123-140.

10. GERALDI, João Wanderley. Linguagem, cultura e educação: a formação científica de profissionais educadores. In: NOGUEIRA, Adriano. Ciência para quem? Formação científica para quê?: a formação do professor conforme desafios regionais. Campo Mourão: FECILCAM; Petrópolis: Vozes, 2000. p. 75-102.

11. GERALDI, João Wanderley. Notas sobre a exclusão da língua geral e a introdução da língua portuguesa. In: KOMOSINSKI, Leonira Maria Giacomuzzi; KOHLRAUSCH, Regina. A 
linguagem descobrindo mundos: ensino de línguas portuguesa, espanhola e literatura. Erechim: Universidade Regional Integrada do Alto Uruguai e das Missões, 2001. p. 13-27.

12. GERALDI, João Wanderley. Paulo Freire e Mikhail Bakhtin: o encontro que não houve. In: FERREIRA, Norma Sandra de Almeida. (Org.). Leitura: um cons/certo. São Paulo: Companhia Editora Nacional, 2003. p. 45-66. (Edição Especial: 25 anos de Cole).

13. GERALDI, João Wanderley. A diferença identifica. A desigualdade deforma. Percursos bakhtinianos de construção ética e estética. In: FREITAS, Maria Teresa; SOUZA, Solange Jobim e; KRAMER, Sônia (Orgs.). Ciências humanas e pesquisa: leituras de Mikhail Bakhtin. São Paulo: Cortez, 2003. p. 39-56. v. 1.

14. GERALDI, João Wanderley. A linguagem nos processos sociais de constituição da subjetividade. In: VAL, Maria da Graça Ferreira da Costa. (Org.). Reflexões sobre práticas escolares de produção de texto. Belo Horizonte: Autêntica, 2003. p. 15-27. v. 1.

15. GERALDI, João Wanderley. Conteúdos de ensino e conteúdos escolares: em defesa de uma escola de sistematização de conhecimentos produzidos pelas práticas sociais. In: VEIGA, Juracilda; D'ANGELIS, Wilmar da Rocha. (Orgs.). Escola indígena, identidade étnica e autonomia. Campinas: ALB, 2003. v. 1. p. 65-71.

16. GERALDI, João Wanderley. Convívio paradoxal com o ensino da leitura e escrita. In: ALBANO, Eleonora et al. Saudades da língua. Campinas: Mercado de Letras, 2003. p. 663-684.

17. GERALDI, João Wanderley. Depois do show, como encontrar encantamento? In: DALBOSCO, Cláudio Almir; TROMBETTA, Gerson Luís; LONGHI, Solange Maria. (Orgs.). Sobre filosofia e educação: subjetividade - intersubjetividade na fundamentação da práxis pedagógica. Passo Fundo/RS: UPF Editora/Universidade de Passo Fundo-Editora Universitária, 2004. p. 360-375. v. 1.

18. GERALDI, João Wanderley. Alteridades: espaços e tempos de instabilidades. In: NEGRI, Lígia; FOLTRAN, Maria José; OLIVEIRA, Roberta Pires. (Orgs.). Sentido e significação: em torno da obra de Rodolfo Ilari. São Paulo: Contexto, 2004. p. 228-243. v. 1.

19. GERALDI, João Wanderley. Paulo Freire e Mikhail Bakhtin: o encontro que não houve. In: GERALDI, João Wanderley; CORTEZÃO, Luiza; NUNES, Rosa; FREIRE, Abreu; TRINDADE, Rui; ROMÃO, João Eustáquio. (Orgs.). Diálogos através de Paulo Freire. Porto-Portugal: Edição Instituto Paulo Freire de Portugal e Centro de Recursos Paulo Freire da FPCE, 2004. p. 63-88. v. 1.

20. GERALDI, João Wanderley. A presença do texto na sala de aula. In: LARA, Gláucia Muniz Proença. (Org.). Língua(gem), texto, discurso: entre a reflexão e a prática. Rio de Janeiro: Lucerna; Belo Horizonte: Fale/UFMG, 2006. p. 13-29. v. 1.

21. GERALDI, João Wanderley. Alfabetizações cotidianas: as letras da cidade e a cidade das letras. In: GARCIA, Regina Leite; ZACCUR, Edwirges. (Orgs.). Cotidiano e diferentes saberes. Rio de Janeiro: DP\&A, 2006. p. 59-71. v. 1.

22. GERALDI, João Wanderley. É possível investir nas enunciações, sem as garantias dos enunciados já firmados? In: MIOTELLO, Valdemir et al. Veredas bakhtinianas: de objetos a sujeitos. São Carlos: Pedro \& João Editores, 2006. p. 129-139.

23. GERALDI, João Wanderley. Alterität: räume und Zeiten der Instabilität. In: BENITES, Maria; FICHTNER, Bernd. (Hgg.). Vom Ungang mi Differenz. Globalizierung und Regionalisierung in interkulturellen Diskurs. Oberhausen: Athena, 2007. p. 31-40. 
24. GERALDI, João Wanderley. Leitura: uma oferta de contrapalavras. In: MIOTELLO, Valdemir et al. O espelho de Bakhtin. São Carlos: Pedro \& João Editores, 2007. p. 39-46.

25. GERALDI, João Wanderley. A formação de jovens diante das exigências do mercado de trabalho. In: Comissão de Educação e Cultura da Câmara dos Deputados. (Org.). Perspectivas e propostas na formação para o mundo do trabalho. Brasília: Câmara dos Deputados, 2008. p. 50-55.

26. GERALDI, João Wanderley. Texto e discurso: questões epistemológicas para a Lingüística. In: FIGUEIREDO, Maria Flávia; MENDONÇA, Marina Célia; ABRIATA, Vera Lúcia Rodella. (Orgs.). Sentidos em movimento: identidade e argumentação. Franca: Editora da UNIFRAN, 2008, v. 3. p. 149158.

27. GERALDI, João Wanderley. Ler e escrever: uma mera exigência escolar? In: BRAGANÇA, Inês F. S.; ARAUJO, Mairce S.; ALVARENGA, Marcia S.; MAURÍCIO, Lúcia V. (Orgs.). Vozes da educação: memórias, histórias e formação de professores. Rio de Janeiro: DP\&A, 2008. p. 123-134.

28. GERALDI, João Wanderley. Correlações entre as situações políticas e as preocupações com a língua portuguesa. In: CINTRA, Anna Maria Marques. (Org.). Ensino de língua portuguesa: reflexão e ação. São Paulo: EDUC, 2008, p. 13-34.

29. GERALDI, João Wanderley. A infatigável tarefa de frear a língua. In: MOURA, Denilda. (Org.). Os desafios da língua: pesquisas em língua falada e escrita. Maceió: EDUFAL, 2008. p. 15-19.

\subsubsection{Capítulos de livros - como co-autor}

1. GERALDI, João Wanderley; GUIMARÃES, Eduardo Roberto Junqueira; Ilari, Rodolfo. Argumentative operators and dialogue. In: DASCAL, Marcelo (Org.). Dialogue: an interdisciplinary approach. Amsterdam/Philadelphia: John Benjamins Publishing Company, 1985. p. 147-163.

2. GERALDI, João Wanderley; GERALDI, Corinta Maria G. Tecnologias na escola, tecnologias da escola. In: BENITES, Maria; FICHTNER, Bernd; MALDONADO, Carlos; HAAS, Lurdi et al. Janelas para o mundo: um projeto de pesquisa e ação. Diálogos com outras vozes. Porto Alegre: Livraria do arquiteto, 2006.

\subsection{ARTIGOS EM PERIÓDICOS}

\subsubsection{Artigos em periódicos - como autor}

1. GERALDI, João Wanderley. Algumas observações sobre o estudo da significação. Série estudos, Uberaba, n. 5, p. 46-55, 1978.

1. GERALDI, João Wanderley. Notas para uma tipologia lingüística dos períodos hipotéticos. Série estudos, Uberaba, n. 7, p. 72-85, 1981.

2. GERALDI, João Wanderley. Ensino da língua ou ensino da metalinguagem? Cadernos da FIDENE, Ijuí, n. 18, p. 5-12, 1981.

4. GERALDI, João Wanderley. Unidades básicas do ensino de língua portuguesa. Cadernos da FIDENE, Ijuí, n. 18, p. 13-41, 1981.

5. GERALDI, João Wanderley. Possíveis alternativas para o ensino de língua portuguesa. ANDE, São Paulo, ano 1, n. 4, p. 52-56, 1982.

6. GERALDI, João Wanderley. O circuito do livro e a escola. Boletim informativo FNLIJ, Rio de Janeiro, v. 15, n. 65, p. 121-131, dez. 1983. 
7. GERALDI, João Wanderley. O circuito do livro e a escola. Trabalhos em lingüistica aplicada, Campinas, n. 3, p. 45-60, 1984.

8. GERALDI, João Wanderley. Formas de expressão de condição e hipóteses. Signo, Santa Cruz do Sul, ano 9, n. 15, p. 17-25, 1984.

9. GERALDI, João Wanderley. Prática da leitura de textos na escola. Leitura: teoria \& prática, Campinas, ano 3, n. 3, p. 25-33, 1984.

10. GERALDI, João Wanderley. Prática da leitura de textos na escola. Boletim da APLL-RS, Porto Alegre, ano 2, n. 3, p. 13-29, 1984.

11. GERALDI, João Wanderley. Escrita, uso da escrita e avaliação. Cadernos CEDES, Campinas, n. 14, p. 30-33, 1985. (2. ed., 1988)

12. GERALDI, João Wanderley. Aprende-se a escrever escrevendo. Signo, Santa Cruz do Sul, ano 10, n. 16, p. 27-31, 1985.

13. GERALDI, João Wanderley. Prática de produção de textos na escola. Trabalhos em lingüistica aplicada, Campinas, n. 7, p. 23-29, 1986.

14. GERALDI, João Wanderley. Aprende-se a escrever escrevendo. Leitura: estudos lingüísticos e literários, Maceió, n. 1, p. 51-55, 1987.

15. GERALDI, João Wanderley. A leitura na sala de aula: as muitas faces de um leitor. Idéias, São Paulo, n. 5, p. 79-84, 1988.

16. GERALDI, João Wanderley. Educação e linguagem. Leitura: teoria \& prática, Campinas, ano 8, n. 14, p. 37-39, 1989.

17. GERALDI, João Wanderley. Texto: um problema para o exercício da capatazia. Contexto \& educação, Ijuí, n. 16, p. 79-85, 1989.

18. GERALDI, João Wanderley. Texto: um problema para o exercício da capatazia. Letras de hoje, Porto Alegre, ano 25, n. 1, p. 153-161, 1990.

19. GERALDI, João Wanderley. Algumas funções da leitura na formação de técnicos. SENAI, A biblioteca na escola, São Paulo, brochura s/n., p. 13-26, 1991.

20. GERALDI, João Wanderley. O ensino e as diferentes instâncias de uso da linguagem. Em aberto, Brasília, ano 10, n. 52, p. 3-12, dez. 1992.

21. GERALDI, João Wanderley. A constituição do sujeito leitor. Revista de educação, APEOESP, São Paulo, n. 7, p. 26-27, 1992.

22. GERALDI, João Wanderley. Ensino de gramática x reflexão sobre a língua. Dois pontos: teoria e prática em educação, Belo Horizonte, v. 2, n. 15, p. 11-14, out./nov. 1993.

23. GERALDI, João Wanderley. Cadernos de estudos lingüisticos: 20 números depois. Cadernos de estudos lingüísticos, Campinas, n. 24, p. 8-17, jan./ jul. 1993.

24. GERALDI, João Wanderley. Construção de um novo modo de ensinar e de aprender a língua portuguesa. Escola e vídeo, Rio de Janeiro, n. 9, p. 28-29, ago. 1994. 
25. GERALDI, João Wanderley. Português: o aprendizado que vem da vida do próprio aluno. Nova escola, São Paulo, n. 78, p. 10-17, set. 1994.

26. GERALDI, João Wanderley. A produção do texto escolar: processos e produtos. Linha d'água, São Paulo, n. 4, p. 129-136, 1995. (Série: volume especial).

27. GERALDI, João Wanderley. Abordagem sócio-interacionista no ensino, leitura e escrita. Revista de educação AEC, Brasília, n. 101, p. 71-81, 1996.

28. GERALDI, João Wanderley. Descrição da língua e ensino da língua. Boletim da ABRALIN, Rio de Janeiro, v. 19, p. 9-13, dez. 1996.

29. GERALDI, João Wanderley. Convívio paradoxal com o ensino da leitura e escrita. Cadernos de estudos lingüisticos, Campinas, n. 31, p. 127-144, jul./dez. 1996.

30. GERALDI, João Wanderley. A prática escolar sob escrutínio. Organon, Porto Alegre, n. 25, p. 1536, 1997.

31. GERALDI, João Wanderley. Paulo Freire: narrador e pensador. Leitura: teoria \& prática, Campinas, ano 16, n. 30, p. 14-19, dez. 1997.

32. GERALDI, João Wanderley. O uso como lugar de construção dos recursos lingüísticos. Instituto Nacional de Educação de Surdos (INES), Brasília, n. 8, p. 49-54, dez. 1997.

33. GERALDI, João Wanderley. Culturas orais em sociedades letradas. Letras, Campinas, v. 19, n. 1/2, p. 9-16, dez. 2000.

34. GERALDI, João Wanderley. Culturas orais em sociedades letradas. Educação \& sociedade, Campinas, ano 21, v. 73, p. 100-108, dez. 2000.

35. GERALDI, João Wanderley. Palavras escritas, indícios de palavras ditas. Quaestio, São Paulo, ano 2, n. 2, p. 9-20, nov. 2000.

36. GERALDI, João Wanderley. A linguagem nos processos sociais de constituição da subjetividade. A paixão de aprender, Porto Alegre, n. 13, p. 42-51, mar. 2001.

37. GERALDI, João Wanderley. Culturas orais e língua escrita: três retratos três por quatro. Palavras, Lisboa, n. 21, p. 49-60, primavera de 2002.

38. GERALDI, João Wanderley. Leitura: uma oferta de contrapalavras. Educar em Revista, Universidade Federal do Paraná, Curitiba, n. 20, p. 77-85, 2002.

39. Geraldi, João Wanderley. Depois do 'show', como encontrar encantamento? Cadernos de estudos lingüisticos, Campinas, v. 44, n. 44, p. 251-261, 2003.

40. GERALDI, João Wanderley. Palavras escritas, indícios de palavras ditas. Linguagem em discurso, Tubarão, v. 3, p. 09-25, 2003.

41. GERALDI, João Wanderley. Depois do show, como encontrar encantamento? Palavras, Lisboa, v. 25, p. $75-83,2004$.

42. GERALDI, João Wanderley. A linguagem em Paulo Freire. Educação, sociedade \& culturas, Porto/Portugal, v. 23, p. 7-17, 2005. 
43. GERALDI, João Wanderley. Pesquisa em linguagem na contemporaneidade. Quaestio, São Paulo, v. 8, p. $63-72,2006$.

44. GERALDI, João Wanderley. Há funções para o ensino escolar da gramática? Discutindo Língua Portuguesa, São Paulo, v. 1, p. 28-33, 2006.

45. GERALDI, João Wanderley. Pesquisa em linguagem na contemporaneidade. Palavras, Lisboa, v. 31, p. 57-64, 2007.

46. GERALDI, João Wanderley. Alteridades: espaços e tempos de instabilidades. Cadernos Camilliani, Cachoeiro do Itapemirim, v. 8, p. 11-23, 2007.

47. GERALDI, João Wanderley. Mensagem aos leitores que vão nascer. Revista Freinet, ABDEPP, Natal, v. 2, p. 52-56, 2007.

48. GERALDI, João Wanderley. O paradoxo aplicado. Signótica, Universidade Federal de Goiás, Goiânia, v. 19, n. 2, p. 157-175, jul./dez. 2007.

49. GERALDI, João Wanderley. "Essencialidades" em Paulo Freire: ser, falar e conhecer. Cadernos de pesquisa em educação, Universidade Federal do Espírito Santo, Vitória, n. 25, p. 9-23, 2007.

50. GERALDI, João Wanderley. Problematizar o futuro não é perder a memória do que há de vir. Revista ECOS, Cáceres, ano V, n. 5, p. 67-70, 2007.

51. GERALDI, João Wanderley. Mediações pedagógicas no processo de produção de textos. Ciclos em revista, Wak Editora, Rio de Janeiro, v. 3, p. 46-65, 2007.

52. GERALDI, João Wanderley. Ingo Voese: notas biográficas \& lembranças de convívio. Signo, Santa Cruz do Sul, v. 33, p. 14-22, 2008.

53. Geraldi, João Wanderley. Construção de uma compreensão. Signo, Santa Cruz do Sul, v. 33, p. 56$58,2008$.

\subsubsection{Artigos em periódicos - como co-autor}

1. GERALDI, João Wanderley; CRUZ, Celene Margarida. Caracterização sumária dos sujeitos falantes no mundo imaginário de Walt Disney. Signo, Santa Cruz do Sul, n. 10, p. 28-36, 1980.

2. GERALDI, João Wanderley; GUIMARÃES, Eduardo Roberto Junqueira; ILARI, Rodolfo. Operadores de argumentação e diálogo. Cadernos de estudos lingüísticos, Campinas, n. 9, p. 143$157,1985$.

3. GERALDI, João Wanderley; RUIZ, Eliana M.; FIAD, Raquel Salek; SILVA, Lilian Lopes Martin. O livro didático de língua portuguesa: didatização e destruição da atividade lingüística. Trabalhos em lingüística aplicada, Campinas, n. 7, p. 81-86, 1986.

4. GERALDI, João Wanderley; ABAURRE, Maria Bernadete; SABINSON, Maria Laura T. Mayrink; FIAD, Raquel Salek. Considerações sobre a utilização de um paradigma indiciário na análise de episódios de refacção textual. Trabalhos em lingüistica aplicada, Campinas, n. 25, p. 523, 1995.

5. GERALDI, João Wanderley; CITELLI, Beatriz Helena Marão; JESUS, Conceição Aparecida de; AZEVEDO, Claudinéia Barbosa de; TEIXEIRA, Elisa Duarte; SERCUNDES, Maria Madalena 
Iwamoto; TARDELLI, Marlete Carboni. A circulação escolar de textos produzidos por alunos. Linha d'água, São Paulo, número especial, p. 129-136, jun. 1995.

6. GERALDI, João Wanderley; SILVA, Lilian Lopes Martin da; FIAD, Raquel Salek. Lingüística, ensino de língua materna e formação de professores. D.E.L.T.A, Brasília, v. 12, n. 2, p. 307-326, 1996.

7. GERALDI, João Wanderley; COLLARES, Cecília Azevedo Lima; MOYSÉS, Maria Aparecida Affonso. Educação continuada: a política da descontinuidade. Educação \& sociedade, Campinas, ano 20, n. 68, p. 202-219, dez. 1999.

8. GERALDI, João Wanderley; COLLARES, Cecília Azevedo Lima; MOYSÉS, Maria Aparecida Affonso. As aventuras do conhecer: da transmissão à interlocução. Educação \& sociedade, Campinas, ano 23, n. 78, p. 91-116, abr. 2002.

9. GERALDI, João Wanderley; GERALDI, Corinta Maria Grisolia. Avaliação: gestos necessários. Práxis, Cacoal/RO, v. 5, p. 27-37, 2004.

10. GERALDI, João Wanderley; ALARCÃO, Isabel; ANDRADE, Ana Isabel; MOREIRA, Antonio; SÁ, Cristina Manuela; PEREIRA, Luísa Álvares; CANHA, Manuel Bernardo; ANÇÃ, Maria Helena; ARAÚJO E SÁ, Maria Helena; CARDOSO, Teresa; GAMITO, Mário; PINTO, Susana. Percursos de consolidação da didáctica de línguas em Portugal: análise dos estudos realizados no âmbito das unidades de investigação, subsidiadas pela Fundação para a Ciência e Tecnologia, na área das ciências da educação. Investigar em Educação, Revista da Sociedade Portuguesa de Ciências da Educação, Braga, n. 3, p. 237-302, jun. 2004.

11. GERALDI, João Wanderley; COLLARES, Cecília Azevedo Lima; MOYSÉS, Maria Aparecida Affonso. Compaginar concepções: ciência e formação no horizonte de possibilidades de um projeto coletivo. Polifonia, Universidade Federal de Mato Grosso (UFMT), Cuiabá/MT, v. 12, p. 47-64, 2006.

\subsection{ENTREVISTAS}

\subsubsection{Entrevistas - como autor}

1. GERALDI, João Wanderley. Educação na parede. Folha de Londrina, Londrina, n. 9, p. 13. 1985. Entrevista.

2. GERALDI, João Wanderley. Método se baseia na produção de textos. Folha de S. Paulo, São Paulo, n. ?, p. A-13, 9 set. 1987. Entrevista.

3. GERALDI, João Wanderley. Livro didático de língua portuguesa: a favor ou contra? Leitura: teoria \& prática, Campinas, n. 9, p.4-7, jun. 1987. Entrevista. (Entrevistador: Ezequiel Teodoro da Silva)

4. GERALDI, João Wanderley. São-luizense aprovado com distinção e louvor em tese de doutorado. A Notícia, São Luiz Gonzaga, n., p. 14/15, jul. 1990. Entrevista. (Entrevistadora: Maria Conceição Grisolia Souza.)

5. GERALDI, João Wanderley. A linguagem reflete a pobreza cultural. $O$ popular, Goiânia, n., Caderno 2, p. 5., 28 set. 1993. Entrevista. (Entrevistador: Antônio Lisboa)

6. GERALDI, João Wanderley. Repensando o curso de Letras. Revista Guairacá, Guarapuava, n.11, p. 7-10, nov. 1994. Entrevista. 
7. GERALDI, João Wanderley. Carreira em debate. Jornal do STU, Campinas, ano 1, n. 0, p. 8, out. 1995. Entrevista.

8. GERALDI, João Wanderley. Em defesa do acesso ao mundo da escrita. Proleitura, Unesp/Uem/Uel, Assis, p. 1-2, abr. 1996. Entrevista.

9. GERALDI, João Wanderley. Prof. Wanderley Geraldi, diretor do IEL, fala ao SAS. Boletim informativo, Campinas, ano 7, n. 8, 26 mar. 1997. Entrevista.

10. GERALDI, João Wanderley. Recuperando as práticas de interlocução na sala de aula. Presença pedagógica, Belo Horizonte, v.4, n. 24, p. 5-19, nov./dez. 1998. Entrevista. (Entrevistadores: Graça Costa Val e Antônio Augusto G. Batista).

11. GERALDI, João Wanderley. Aos mestres, a leitura. Tribuna, Natal, ano 49, n. 182, p. 7, 23 set. 1999. Entrevista.

12. GERALDI, João Wanderley. Trajetória com ética e genialidade. Jornal da UNICAMP, Campinas, ano 15, n. 166, p. 3, set. 2001. Entrevista. (Caderno temático em homenagem a Carlos Franchi).

13. GERALDI, João Wanderley. João Wanderley Geraldi. In: XAVIER, Antonio Carlos; CORTEZ, Suzana (Orgs.). Conversas com lingüistas: virtudes e controvérsias da lingüística. São Paulo: Parábola, 2003. Entrevista.

14. GERALDI, João Wanderley. Entrevista [24/06/2004]. Universidade Estadual de Campinas, Campinas, 2004. 1 fita cassete (30 min). Não-publicada. (Entrevistadora: Luzia de Fátima Paula).

15. GERALDI, João Wanderley. Um bom professor ensina a perguntar. Letra A, Belo Horizonte, ano 2, n. 6, p. 10-12, abr./maio 2006. Entrevista.

16. GERALDI, João Wanderley. A linguagem nos processos sociais de constituição da subjetividade. Academia Livros e Letras, Belo Horizonte, 2007. Entrevista.

17. GERALDI, João Wanderley. Leitura: atividade humana e não apenas escolar. Universidade Potiguar, Natal/RN, 2008. Entrevista.

18. GERALDI, João Wanderley. Professor não pode ter medo de errar. Na Ponta do Lápis, CENPEC, São Paulo, 2008. Entrevista.

19. GERALDI, João Wanderley. Os pecados da Lingüística. Palavras, APP, Lisboa, 2008. Entrevista.

20. GERALDI, João Wanderley. Entrevista [05/09/2008]. Núcleo de Estudos e Pesquisas da Educação na Pequena Infância (NUPEIN), Centro de Ciências da Educação, Universidade Federal de Santa Catarina, 2008. (Entrevistadoras: Márcia Buss Simão, Pricilla C. Trierweiller e Rosinete Schmitt). Disponível em: http://www.ced.ufsc.br/nupein.

\subsubsection{Entrevistas - como co-autor}

1. GERALDI, João Wanderley; OSAKABE, Haquira; ROMUALDO, Jonas de Araújo; POSSENTI, Sírio. O efeito das palavras. Veja, São Paulo, n. 712, p. 22-23, 28 abr. 1982. Entrevista.

2. GERALDI, João Wanderley; FIAD, Raquel Salek; SILVA, Lílian Lopes Martin da. Para repensar o ensino de português. Jornal da UNICAMP, Campinas, ano 3, n. 29, p. 4, mar.1989. Entrevista.

3. GERALDI, João Wanderley; FIAD, Raquel Salek. A sala de aula é uma oficina de dizer coisas. Nova escola, São Paulo, n. 78, p. 18-20, 1994. Entrevista. 
4. GERALDI, João Wanderley; GERALDI, Corinta; CARBÓ, Victoria; MAUCH, Carla; GONZÁLEZ, Tomás; GONZÁLEZ, Vera; GONZÁLEZ, Fernando; LARROSA, Miréia; LARROSA, Jorge. Leitura e escrita na escola podem ser livres? Presença pedagógica, Belo Horizonte, v.11, p. 519, nov./dez. 2005. Entrevista.

\subsection{TEXTOS EM ANAIS DE EVENTOS}

\subsubsection{Textos em anais de eventos - como autor}

1. GERALDI, João Wanderley. De como produzir milagres ou o professor pega um boizinho, rifa e compra livros. In: CONGRESSO DE LEITURA DO BRASIL, 5., 1986, Campinas. Comunicações oficiais: anais. Campinas: ALB, 1986. p. 43-50.

2. GERALDI, João Wanderley. Prática de produção de textos na escola. In: ENCONTRO DE PROFESSORES DE REDAÇÃO DO ESTADO DO RIO DE JANEIRO, 3., 1986, Rio de Janeiro. Anais... Rio de Janeiro: PUC, 1986. p. 159-170.

3. GERALDI, João Wanderley. Cinco questões sobre a questão dos métodos. In: CONGRESSO DE LEITURA DO BRASIL, 6., 1988, Campinas. Conferências e mesas-redondas: anais. Campinas: ALB, 1988. p. 81-85.

4. GERALDI, João Wanderley. A propósito do outro: imagem, construção e cumplicidade. In: CONGRESSO DE LEITURA DO BRASIL, 7., 1991, Campinas. Conferências e mesas-redondas: anais. Campinas: ALB, 1991. p. 21-25.

5. GERALDI, João Wanderley. Ainda e sempre: leitura. In: CONGRESSO DE LEITURA DO BRASIL, 8., 1992, Campinas. Leitura: autonomia, trabalho e cidadania: anais. Campinas: ALB, 1992. p. 195-198.

6. GERALDI, João Wanderley. A escrita como trabalho: operações e meta-operações de construção de textos. In: ESTUDOS LINGÜÍSTICOS, 23., 1994, São Paulo. Seminários do grupo de estudos lingüísticos: anais. São Paulo: GEL/CNPq, 1994. p. 373-380.

7. GERALDI, João Wanderley. Políticas de inclusão em estruturas de exclusão. In: SIMPÓSIO INTERNACIONAL SOBRE A LEITURA E A ESCRITA NA SOCIEDADE E NA ESCOLA, s./n., 1994, Brasília. Leitura e escrita na sociedade e na escola: anais. Brasília: MEC/UNESCO; Belo Horizonte: Fundação AMAE, 1994. p. 65-78.

8. GERALDI, João Wanderley. Linguagem, subjetividade e ensino de língua estrangeira. In: CONGRESSO BRASILEIRO DE PROFESSORES DE ALEMÃO, 3., 1996, Campinas. Anais... Campinas: ABRAPA, 1996. p. 101-112.

9. GERALDI, João Wanderley. A prática escolar sob escrutínio. In: ENCONTRO NACIONAL DE DIDÁTICA E PRÁTICA DE ENSINO, 8., 1996, Florianópolis. Anais... Florianópolis: [s. n.], 1996. v. 2, p. 25-47.

10. GERALDI, João Wanderley. Da produção do texto escolar. In: JORNADA NACIONAL DE LITERATURA, 5., 1997, Passo Fundo. Anais... Passo Fundo: [s. n.], 1997. p. 223-226.

11. GERALDI, João Wanderley. Sobre a constituição dos objetos de ensino em língua materna. In: COLÓQUIO SOBRE QUESTÕES CURRICULARES, 4., 2000. Braga. Politicas curriculares: 
caminhos da flexibilização e integração: actas. Universidade do Minho (Braga): Centro de Estudos em Educação e Psicologia, 2000. p. 369-378.

12. Geraldi, João Wanderley. A complexa construção de um campo de estudos: subsídios para uma discussão sobre educação lingüística. In: SEMINÁRIO EDUCAÇÃO LINGÜÍSTICA, 1., 2003. Coimbra. Configuração e reconfigurações: anais. Universidade de Coimbra: Coimbra, 2003. p. 5-10.

13. GERALDI, João Wanderley. A linguagem em Paulo Freire. In: ENCONTRO INTERNACIONAL DO FÓRUM PAULO FREIRE, 4., 2004. Porto. Caminhando para uma cidadania multicultural: anais. Porto: [s. n.], 2004.

14. GERALDI, João Wanderley. Problematizar o futuro não é perder a memória do que há de vir. In: ENCONTRO INTERNACIONAL DO FÓRUM PAULO FREIRE, 4., 2004. Porto. Caminhando para uma cidadania multicultural: anais. Porto: [s. n.], 2004.

15. GERALDI, João Wanderley. Texto e discurso: questões epistemológicas para a Lingüística. In: FÓRUM NACIONAL DISCURSO E TEXTUALIDADE, 1., 2007. Jequié. Olhares sobre o texto, o lugar do texto e o texto como lugar: anais. Jequié: UESB, 2007. p. 8-17.

\subsubsection{Textos em anais de eventos - como co-autor}

1. GERALDI, João Wanderley; CRUZ, Celene Margarida. Orientação argumentativa e pressuposição. In: ESTUDOS LINGÜÍSTICOS, 1., 1978, Mogi das Cruzes. Seminários do grupo de estudos lingüísticos: anais. Mogi das Cruzes: Universidade de Mogi das Cruzes, 1978. p. 81-95.

2. GERALDI, João Wanderley; SÂNDALO, Maria Filomena Spatti. Cancelador de implicatura $x$ operador argumentativo: análise da partícula "hoaga" do Pirahã. In: ESTUDOS LINGÜÍSTICOS, 7., 1988, Santos. Seminários do grupo de estudos lingüisticos: anais. Santos: UNISANTOS, 1988. p. 327336.

3. GERALDI, João Wanderley; ROMUALDO, Jonas A.; POSSENTI, Sírio; OSAKABE, Haquira. A interlocução no debate político. In: ESTUDOS LINGÜÍSTICOS, 7., 1988, Santos. Seminários do grupo de estudos lingüísticos: anais. Santos: UNISANTOS, 1988. p. 131-149.

4. GERALDI, João Wanderley; MOREIRA, Liliane. Nem: operador argumentativo? In: ESTUDOS LINGÜÍSTICOS, 15., 1988, Santos. Seminários do grupo de estudos lingüísticos: anais. Santos: UNISANTOS, 1988. p. 354-363.

5. GERALDI, João Wanderley; FIAD, Raquel Salek; ABAURRE, Maria Bernadete M.; MAYRINKSABINSON, Maria Laura Trindade. O caráter singular das operações de refacção nos textos representativos do início da aquisição da escrita. In: ESTUDOS LINGÜÍSTICOS, 24., 1995, São Paulo. Seminários do grupo de estudos lingüísticos: anais. São Paulo, 1995. p. 76-84.

6. GERALDI, João Wanderley; CHIAPPINI, Lígia; MICHELETTI, Guaraciaba; CITELLI, Adilson. A circulação de textos na escola: primeiros resultados. In: ESTUDOS LINGÜÍSTICOS, 24., 1995, São Paulo. Seminários do grupo de estudos lingüísticos: anais. São Paulo, 1995. p. 42-49.

7. GERALDI, João Wanderley; COLLARES, Cecília L.; MOYSÉS, Maria Aparecida Affonso. A integração disciplinar pelo foco das práticas educativas: uma proposta curricular para um programa de mestrado. In: COLÓQUIO SOBRE QUESTÕES CURRICULARES, 4., 2000, Braga. Políticas curriculares: caminhos da flexibilização e integração: actas. Universidade do Minho (Braga): Centro de Estudos em Educação e Psicologia, 2000. p. 321-329. 


\subsection{ARTIGOS EM JORNAIS DE NOTÍCIAS}

\subsubsection{Artigos em jornais de notícias - como autor}

1. GERALDI, João Wanderley. Eça de Queiroz, a língua padrão, o ensino e quejandos outros. $O$ Paraná: jornal de fato, Cascavel, 20 out. 1984. p. 2.

2. GERALDI, João Wanderley. Aos que resistem, a exigência do novo tempo. O Estado de S. Paulo, São Paulo, 14 maio 1995. Caderno 2, p. 4.

3. GERALDI, João Wanderley. Leitura, objeto de incentivo e repressão. Correio Popular, Campinas, 22 jul. 1995, Caderno C, p.

\subsubsection{Artigos em jornais de notícias - como co-autor}

1. GERALDI, João Wanderley; RUIZ, Eliana Maria; SILVA, Lílian Lopes Martins da; FIAD, Raquel Salek. A destruidora didática dos livros. Leia, São Paulo, n.?, p. 41-43, mar. 1986.

\subsection{RESENHAS}

\subsubsection{Resenhas - como autor}

1. ILARI, Rodolfo. A lingüistica e o ensino da língua portuguesa. São Paulo: Martins Fontes, 1985. 88 p. Resenha de: GERALDI, João Wanderley. [sem título]. Leitura: teoria \& prática, Campinas, ano 4, n. 5, p. 57-58, jun. 1985.

2. LACERDA, Nilma Gonçalves. Manual de tapeçaria. Rio de Janeiro: Philobiblion/Fundação Rio, 1986. 231 p. Resenha de: GERALDI, João Wanderley. O fio da meada. Leia, São Paulo, ano 9, n. 104, p. 50, jun. 1987.

3. LUFT, Celso Pedro. Dicionário prático de regência verbal. São Paulo: Ática, 1987. 544 p. Resenha de: GERALDI, João Wanderley. Útil, mas prescindível. Leia, São Paulo, ano 10, n. 110, p. 56, dez. 1987.

4. MESTRE, David. Nem tudo é poesia. Luanda: União dos Escritores de Angola, 1988. Resenha de: GERALDI, João Wanderley. Breve nota sobre as notas de Mestre David. Estudos portugueses e africanos, Luanda, n. 12, p. 91-93, 1988.

5. FRANZONI, Patrícia Hilda. Nos bastidores da comunicação autêntica. Campinas: Ed. UNICAMP, 1993. Resenha de: GERALDI, João Wanderley. Autenticidade x artificialidade no ensino de línguas. Leitura: teoria \& prática, Campinas, ano 13, n. 23, p. 64-66, jun. 1994.

6. FREITAS, Maria Ester de. Viva a tese! Um guia de sobrevivência. São Paulo: Fundação Getúlio Vargas, 2001. Resenha de: GERALDI, João Wanderley. Revista de administração de empresas (RAE), São Paulo, v. 42, n. 3, p. 118-119, jul. set. 2002.

7. GERALDI, João Wanderley. Destaques bibliográficos. Resenha de: GERALDI, João Wanderley. Palavras, Lisboa, Associação de Professores de Português, n. 22, p. 92-94, 2003.

8. GARCIA, Regina Leite. (Org.). Método, métodos, contramétodo. São Paulo: Cortez, 2003. GARCIA, Regina Leite. (Org.). Método: pesquisa com o cotidiano. Rio de Janeiro: DP\&A, 2003. 
Resenha de: GERALDI, João Wanderley. Pelos caminhos e descaminhos dos métodos. Educação \& Sociedade, Campinas, v. 25, n. 87, p. 601-610, 2004.

\subsubsection{Resenha - como co-autor}

1. KATO, Mary A. No mundo da escrita: uma perspectiva psicolingüística. São Paulo: Ática, 1987. 144 p. Resenha de: GERALDI, João Wanderley; SABINSON, Maria Laura Mayrink. Título? D.E.L.T.A, Brasília, v. 3, n. 1, p. 117-125, 1987.

\subsection{PREFÁCIOS E APRESENTAÇÕES DE LIVROS}

1. GERALDI, João Wanderley. O ensino é livresco, mas sem livros. Prefácio. In: SILVA, Ezequiel Teodoro da. Elementos de pedagogia da leitura. São Paulo: Martins Fontes, 1988. p. 9-13.

2. GERALDI, João Wanderley. Prefácio. In: GARCEZ, Lucília Helena do Carmo. A escrita e o outro. Brasília: Ed. UnB, 1988. p. 13-16.

3. GERALDI, João Wanderley. Prefácio. In: BRITTO, Luiz Percival Leme. Fugindo da norma. Campinas: Editora Átomo, 1991. p. 3-4.

4. GERALDI, João Wanderley. Trouxeste a chave. Prefácio. In: MAGNANI, Maria do Rosário Mortatti. Em sobressaltos: formação de professora. Campinas: Ed. UNICAMP, 1993. p. 11-14.

5. GERALDI, João Wanderley. Da redação à produção de textos. Prefácio. In: GERALDI, João Wanderley; CITELLI, Beatriz (Coords.). Aprender e ensinar com textos de alunos. São Paulo: Cortez, 1997. 184 p. p. 17-24. (Aprender e ensinar com textos, v. 1 - Coordenadora geral: Lígia Chiappini).

6. GERALDI, João Wanderley. Prefácio. In: LARA, Gláucia Muniz Proença. Autocorreção e autoavaliação na produção de textos escolares. Campo Grande: Ed. UFMS, 1999. p. 11-13.

7. GERALDI, João Wanderley. Sagacidade, argúcia e lupa. Prefácio. In: ILARI, Rodolfo. Introdução à Semântica: brincando com a gramática. São Paulo: Contexto, 2001. p. 9-10.

8. GERALDI, João Wanderley. Ser esta metamorfose ambulante. Prefácio. In: MOYSÉS, Maria Aparecida Affonso. A institucionalização invisivel: crianças que não-aprendem-na-escola. Campinas: Mercado de Letras; São Paulo: FAPESP, 2001. p. 9-14.

9. GERALDI, João Wanderley. Apresentação. In: CITELLI, Beatriz. Produção e leitura de textos no ensino fundamental. São Paulo: Cortez, 2001. p. 7-10.

10. GERALDI, João Wanderley. Apresentação. In: REDAÇÕES DO VESTIBULAR DA UNICAMP 2001. Campinas: PRG-CONVESTt/PRE- UNICAMP, 2001. p. 15-28.

11. GERALDI, João Wanderley; POSSENTI, Sírio. Apresentação. In: GABLER, Iracema; GURGEL, Nair; PARMIGIANI, Tânia Rocha. Análise do discurso: uma leitura e três enfoques. Porto Velho: EDUFRO, 2001. p. 7-15.

12. GERALDI, João Wanderley. Para tecer um amanhã. Apresentação. In: TARDELLI, Marlette Carboni. O ensino da língua materna: interações em sala de aula. São Paulo: Cortez, 2002, p. 11-16.

13. GERALDI, João Wanderley. Pela mão de Graciliano. Prefácio. In: LEMOS, Taísa Viliese de. Um ensaio sobre a formação da subjetividade na psicologia sócio-histórica. Juiz de Fora: Editora da UFJF/Musa Editora, 2002, p. 7-12. 
14. GERALDI, João Wanderley. Recuperar memórias silenciadas. Prefácio. In: BERENBLUM, Andréa de. A invenção da palavra oficial: identidade, língua nacional e escola em tempos de globalização. Belo Horizonte: Autêntica, 2003, p. 15-18.

15. GERALDI, João Wanderley. Liberar gestos travados. Apresentação. In: FERREIRA, Gláucia de Melo. (Org.). Palavra de professor (a): tateios e reflexões na prática da pedagogia Freinet. Campinas: Mercado de Letras, 2003, p. 9-12.

16. GERALDI, João Wanderley. A arte de formular perguntas. Prefácio. In: NERY, Rosa Maria. Questões sobre questões de leitura. Campinas: ALB/Alínea, 2003, p. 11-12.

17. GERALDI, João Wanderley. Apresentação. In: Voz do Professor. São Paulo: Fundação Itaú Social/CENPEC, 2003, p. 5.

18. GERALDI, João Wanderley. Apresentação. In: VOESE, Ingo. Análise do Discurso e o ensino de língua portuguesa. São Paulo: Cortez Editora, 2004, p. 9-13.

19. GERALDI, João Wanderley. Saberes da lida, saberes da vida. Prefácio. In: LIMA, Maria Emília Caixeta de Castro. Sentidos do trabalho: a educação continuada de professores. Belo Horizonte: Autêntica, 2005, p. 9-11.

20. GERALDI, João Wanderley. Coragem dos gestos de encontro. Prefácio. In: NUNES, Rosa Soares. Nada sobre nós sem nós: a centralidade da comunicação na obra de Boaventura de Sousa Santos. São Paulo: Cortez, 2005, p. 13-23.

21. GERALDI, João Wanderley. Desdobramentos do móvel. Prefácio. In: MATTE, Ana Cristina Fricke. Entre a reflexão e a prática. (Org.). Belo Horizonte: FALE/UFMG; Rio de Janeiro: Lucerna, 2007, p. 9-11.

22. GERALDI, João Wanderley. Apresentação. In: PONZIO, Augusto. A revolução bakhtiniana: o pensamento de Bakhtin e a ideologia contemporânea. Coordenação de tradução de

Valdemir Miotello. São Paulo: Contexto, 2008.

\subsection{QUARTA CAPA E ORELHAS DE LIVROS}

1. MIRANDA, Regina Lúcia F.; SANTOS, Pensilvânia D. G.; LACERDA, Nilma G. A língua portuguesa no coração de uma nova escola. São Paulo: Ática, 1995. (Quarta capa por João Wanderley Geraldi).

2. KRAMER, Sônia; SOUZA, Solange Jobim e (Orgs.). Histórias de professores. São Paulo: Ática, 1996. (Quarta capa por João Wanderley Geraldi).

3. ACERVO CERTAS PALAVRAS - PROGRAMA DE LIVROS E IDÉIAS. Catálogo 1981-1996, Campinas: IEL/CEDAE/Editora da UNICAMP, 1997. (Primeira orelha por João Wanderley Geraldi).

4. FOCAS, Júnia Diniz. Inconfidência mineira: a história dos sentidos de uma história. Belo Horizonte: Faculdade Letras da UFMG, 2002. (Quarta capa por João Wanderley Geraldi).

5. GHILARDI, Maria Inês; BARZOTTO, Valdir Heitor (Orgs.). Nas telas da mídia. Campinas: ALB/Ed. Alínea, 2002. (Quarta capa por João Wanderley Geraldi). 


\subsection{TRADUÇÕES}

\subsubsection{Traduções - como autor}

1. GRICE, H. Paul. Lógica e conversação. Tradução de João Wanderley Geraldi. In: DASCAL, Marcelo. (Org.). Fundamentos metodológicos da lingüística. São Paulo: Global, 1982. p. 81-104. v. 4.

2. FUCHS, Catherine. A paráfrase lingüística: equivalência, sinonímia ou reformulação? Tradução de João Wanderley Geraldi. Cadernos de estudos lingüisticos, Campinas, n. 8, p. 129-134, 1985.

3. VANDERVEKEN, Daniel. O que é uma força ilocucionária? Tradução de João Wanderley Geraldi. Cadernos de estudos lingüisticos, Campinas, n. 9, p. 173-194, 1985.

4. MEGGLE, Georg. Ao inferno com a teoria dos atos de fala. Tradução de João Wanderley Geraldi. Cadernos de estudos lingüísticos, Campinas, n. 9, p. 195-200, 1985.

5. DUCROT, Oswald. As leis de discurso. Tradução de João Wanderley Geraldi. In: DUCROT, Oswald. $O$ dizer e o dito. Campinas: Pontes, 1987. p. 89-106. (Tradutor responsável: Rev. Téc. Tradução de Eduardo Roberto Junqueira Guimarães).

6. BENVENISTE, Émile. O antônimo e o pronome em francês moderno e a forma e o sentido na linguagem. Tradução de João Wanderley Geraldi. In: BENVENISTE, Émile. Problemas de lingüistica geral. Campinas: Pontes, 1989. p. 201-242. v. 2.

7. ORBE, Fernando Bárcena. O aprendizado do novo: reflexões sobre a tragédia do começo. Tradução de João Wanderley Geraldi. Leituras SME, Campinas, n. 3, p. 9, jul. 2001.

8. BONDIA, Jorge Larrosa. Nota sobre a experiência e o saber da experiência. Tradução de João Wanderley Geraldi. Leituras SME, Campinas, n. 4, p. 8, jul. 2002.

\subsubsection{Traduções - como co-autor}

1. AUTHIER-REVUZ, Jacqueline. Heterogeneidade(s) enunciativa(s). Tradução de João Wanderley Geraldi e Celene Margarida Cruz. Cadernos de estudos lingüisticos, Campinas, n. 19, p. 25-42, 1990.

2. HENRY, Paul. Construções relativas e articulações discursivas. Tradução de João Wanderley e Celene Margarida Cruz. Cadernos de estudos lingüísticos, Campinas, n. 19, p. 43-64, 1990.

3. DASCAL, Marcelo. Código, uso e fundamentos. Tradução de João Wanderley Geraldi e Jonas de Araújo Romualdo. Cadernos de estudos lingüisticos, Campinas, n. 22, p. 47-53, 1992.

4. CHARTIER, Roger. Crítica textual e história cultural: o texto e a voz, séculos XVI-XVII. Tradução de João Wanderley Geraldi e Celene Margarida Cruz. Leitura: teoria \& prática, Campinas, ano 16, n. 30, p. 67-75, dez. 1997.

\subsection{PERIÓDICO}

1. GERALDI, João Wanderley. Subsídios metodológicos para o ensino de língua portuguesa: $5^{\mathrm{a}}$. a $8^{\mathrm{a}}$. séries. Cadernos da FIDENE, Ijuí, n. 18, 70 p., 1981. (2. ed., 1984) 


\subsection{DISSERTAÇÃO, TESES E MEMORIAIS ACADÊMICOS}

1. GERALDI, João Wanderley. Se a semântica fosse também pragmática... ou para uma análise semântica dos enunciados condicionais. 1978. 249 f. il. Dissertação (Mestrado em Lingüística) Instituto de Estudos da Linguagem, Universidade Estadual de Campinas, Campinas. Não-publicado.

2. GERALDI, João Wanderley. Linguagem, interação e ensino. 1990. 334 f. il. Tese (Doutorado em Lingüística) - Instituto de Estudos da Linguagem, Universidade Estadual e Campinas, Campinas.

3. GERALDI, João Wanderley. Exercícios de militância e divulgação. 1995. Tese (Livre Docência em Lingüística) - Instituto de Estudos da Linguagem, Universidade Estadual de Campinas, Campinas. Publicada originalmente como livro: Linguagem e ensino: exercícios de militância e divulgação.

4. GERALDI, João Wanderley. Memorial: 1946 - 1994. 1995. 58 f. Memorial (Concurso de Livre Docência) - Instituto de Estudos da Linguagem, Universidade Estadual de Campinas, Campinas. Nãopublicado.

5. GERALDI, João Wanderley. Memorial: janeiro de 1995 a abril de 1999. 1999. 23 f. Memorial (Promoção a professor adjunto por avaliação de mérito) - Instituto de Estudos da Linguagem, Universidade Estadual de Campinas, Campinas. Não-publicado.

6. GERALDI, João Wanderley. Memorial: maio de 1999 a abril de 2002. 2002. 34 f. Memorial (Promoção a professor titular por avaliação de mérito) - Instituto de Estudos da Linguagem, Universidade Estadual de Campinas, Campinas. Não-publicado.

\subsection{VÍDEOS}

1. GERALDI, João Wanderley. Língua Portuguesa 1. São Paulo: Secretaria de Estado da Educação de São Paulo e TV-Cultura, 1985. (Projeto Ipê).

2. GERALDI, João Wanderley. O desafio da leitura e a contribuição da literatura infantil. São Paulo: Fundação de Desenvolvimento da Educação (FDE), 1987. 1 DVD (167 min), son., color.

3. GERALDI, João Wanderley. Palavra de leitor. São Paulo: Fundação de Desenvolvimento da Educação (FDE), 1990. 1 DVD (19 min), son., color.

4. GERALDI, João Wanderley. Questões do ensino de língua: leitura, gramática e produção de textos. Porto Alegre: Universidade Federal do Rio Grande do Sul (UFRGS), 1991.

5. GERALDI, João Wanderley. Língua portuguesa. São Paulo: Fundação de Desenvolvimento da Educação (FDE)/Sindicato dos Professores do Ensino Oficial do Estado de São Paulo (APEOESP), 1992.

6. GERALDI, João Wanderley. Leitura \& Escola. Rio de Janeiro: Fundação Roberto Marinho e Rede Globo, 1992. (Programa "Mestre é aquele que aprende").

7. GERALDI, João Wanderley. A linguagem nos processos sociais de constituição da subjetividade. Coordenação de Ivan Capdeville Júnior. Belo Horizonte: Academia Livros \& Letras, 20/10/2007. 1 DVD (01.13.58 min), son., color. DVD n. 74. 
8. GERALDI, João Wanderley. A importância do texto na sala de aula. Coordenação de Ivan Capdeville Júnior. Belo Horizonte: Academia Livros \& Letras, 20/10/2007. 1 DVD (01.31.28 min), son., color. DVD n. 75.

9. GERALDI, João Wanderley. A importância do texto na sala de aula. Coordenação de Ivan Capdeville Júnior. Belo Horizonte: Academia Livros \& Letras, 21/10/2007. 1 DVD (01.24.57 min), son., color. DVD n. 76.

\section{BIBLIOGRAFIA SOBRE J. W. GERALDI}

\subsection{CAPÍTULOS DE LIVROS}

1. FREIRE, Paulo. O professor: um profissional para si. In: GERALDI, João Wanderley; NOGUEIRA, Adriano. Paulo Freire: trabalho, comentário, reflexão. Petrópolis: Vozes, 1990. p. 3846.

2. BRITTO, Luiz Percival de Leme. Sujeito da linguagem, sujeito de ensino. In: BRITTO, Luiz Percival de Leme. A sombra do caos: ensino de língua $\mathrm{X}$ tradição gramatical, Campinas: Ed. Mercado de Letras/ALB, 1997. p. 153-165.

3. MORTATTI, Maria do Rosário Longo. Alfabetização: construtivismo e desmetodização. In: MORTATTI, Maria do Rosário Longo. Os sentidos da alfabetização (São Paulo - 1876/1994). São Paulo: Ed. Unesp; Brasília: MEC/INEP/COMPED, 2000. p. 251-288.

4. ROJO, Roxane H. R. O texto no ensino-aprendizagem de línguas hoje: desafios da contemporaneidade. In: TRAVAGLIA, L. C.; FINOTTI, L. H. B.; MESQUITA, E. M. C. (Orgs.). Gêneros de texto: caracterização e ensino. Uberlândia/MG: Editora da Universidade Federal de Uberlândia (EDUFU), 2008. p. 09-43.

\subsection{ARTIGO EM PERIÓDICO}

1. MORTATTI, Maria do Rosário Longo. Uma proposta para o próximo milênio: o pensamento interacionista sobre alfabetização. Presença pedagógica, Belo Horizonte, v. 5, n. 29, p. 21-27, set./out. 1999.

\subsection{RESENHAS}

1. GERALDI, João Wanderley; ILARI, Rodolfo. Semântica. São Paulo: Ática, 1985. 96 p. Resenha de: LOBATO, Lucia Maria Pinheiro. D.E.L.T.A, Brasília, v. 3, n. 1, p. 127-135, fev. 1987.

2. GERALDI, João Wanderley. Portos de passagem. São Paulo: Martins Fontes, 1991. 252 p. Resenha de: FISCHER, Rosa Maria Bueno. Em aberto, Brasília, ano 10, n. 52, p. 69-72, 1992.

\subsection{PREFÁCIOS E APRESENTAÇÕES}

1. COSTA, Iara Benquerer. Prefácio. In: GERALDI, João Wanderley. Subsídios metodológicos para o ensino de língua portuguesa: $5^{\text {a }}$ a $8^{\text {a }}$. séries. Cadernos da FIDENE, Ijuí, n. 18, p. 70, 1981.

2. FRANCHI, Carlos. Prefácio. In: GERALDI, João Wanderley. Portos de passagem. São Paulo: Martins Fontes, 1991.

3. ALBANO, Eleonora Cavalcante. Apresentação. In: CADERNOS DE ESTUDOS LINGÜÍSTICOS. 15 anos de Cadernos: um trabalho de João Wanderley Geraldi. Campinas: Gráfica central (UNICAMP /IEL), n. 24, jan./ jul. 1993. 230 p. Edição especial. 
4. BATISTA, Antonio Augusto G. Apresentação. In: GERALDI, João Wanderley. Entrevista [11/12/1998]. Recuperando as práticas de interlocução na sala de aula. Entrevistadores: Maria da Graça Costa Val e Antônio Augusto G. Batista. Presença pedagógica, v. 4, n. 24, p. 5-19, 1998.

5. ROJO, Roxane; CORDEIRO, Glaís Sales. Apresentação. In: ROJO, Roxane; CORDEIRO, Glaís Sales. Gêneros orais e escritos na escola. Tradução e organização de Roxane Rojo e Glaís Sales Cordeiro. Campinas: Mercado de Letras, 2004.

6. NUNES, Rosa. Apresentação. GERALDI, João Wanderley. Paulo Freire e Mikhail Bakhtin: o encontro que não houve. In: GERALDI, João Wanderley; CORTEZÃO, Luiza; NUNES, Rosa; FREIRE, Abreu; TRINDADE, Rui; ROMÃO, João Eustáquio. (Orgs.). Diálogos através de Paulo Freire. Porto/Portugal: Edição Instituto Paulo Freire de Portugal e Centro de Recursos Paulo Freire da FPCE, 2004. p. 63-88. v. 1.

7. SÁ, Maria Helena de Araújo e. Apresentação. In: GERALDI, João Wanderley. A aula como acontecimento. Aveiro/Portugal: Universidade de Aveiro, Campus de Santiago, 2004. 21 p.

\subsection{ORELHAS DE LIVROS}

1. GERALDI, João Wanderley. (Org.). O texto na sala de aula. São Paulo: Ática, 2005. 136 p. (1ª orelha por Valdir Heitor Barzotto).

2. GERALDI, João Wanderley. (Org.). O texto na sala de aula. São Paulo: Ática, 2005. 136 p. (1ª. orelha por Marinalva Barbosa).

3. GERALDI, João Wanderley. (Org.). O texto na sala de aula. São Paulo: Ática, 2005. 136 p. (1ª orelha por Rosa Hessel).

4. GERALDI, João Wanderley. (Org.). O texto na sala de aula. São Paulo: Ática, 2005. 136 p. (2a . orelha por Sírio Possenti).

5. GERALDI, João Wanderley. (Org.). O texto na sala de aula. São Paulo: Ática, 2005. 136 p. (2a . orelha por Norma Shirakura).

\subsection{PERIÓDICO}

1. CADERNOS DE ESTUDOS LINGÜÍSTICOS. 15 anos de Cadernos: um trabalho de João Wanderley Geraldi. Campinas: Gráfica central (UNICAMP/IEL), n. 24, jan./ jul. 1993. 230 p. Edição especial em homenagem a João Wanderley Geraldi.

\subsection{DISSERTAÇÕES E TESES}

1. GALAN, Maria Raquel Aparecida Coelho. A construção cotidiana de uma proposta de ensino: as falas de professores e alunos de LP do oeste do Paraná. 1991. 139 f. Dissertação (Mestrado em Letras - Lingüística) — Universidade Federal de Santa Catarina, Florianópolis. (Orientação: Maria Marta Furlanetto).

2. SILVA, Lilian Lopes Martin da. Mudar o ensino de língua portuguesa: uma promessa que não venceu nem se cumpriu mas que merece ser interpretada. 1994. 350 f. Tese (Doutorado em Educação) - Faculdade de Educação, Universidade Estadual de Campinas, Campinas. (Orientação: Raquel Salek Fiad). 
3. FONSECA, Maria Nilma Góis da. Ensino de língua portuguesa: ecos de um discurso. Dissertação. 1997. 149 f. (Mestrado em Educação) — Universidade Federal de Sergipe, São Cristóvão/SE. (Orientação: João Wanderley Geraldi).

4. PIVOVAR, Altair. Leitura e escrita: a captura de um objeto de ensino. 1999. 142 f. Dissertação (Mestrado em Letras) - Universidade Federal do Paraná, Curitiba. (Orientação: Carlos Alberto Faraco).

5. PRADO, Guilherme do Val Toledo. Documentos desemboscados: conflito entre o gênero do discurso e a concepção de linguagem nos documentos curriculares de ensino de língua portuguesa. 1999. 169 f. Tese (Doutorado em Lingüística Aplicada) - Instituto de Estudos da Linguagem, Universidade Estadual de Campinas, Campinas. (Orientação: Raquel Salek Fiad).

6. MARINHO, Marildes. A oficialização de novas concepções para o ensino de português no Brasil. 2001. 301 f. Tese (Doutorado em Lingüística) - Instituto de Estudos da Linguagem, Universidade Estadual de Campinas, Campinas. (Orientação: Sírio Possenti).

7. PAUlA, Luzia de Fátima. O ensino de língua portuguesa no Brasil, segundo João Wanderley Geraldi. 2004. 144 f. Dissertação (Mestrado em Educação) — Faculdade de Filosofia e Ciências, Universidade Estadual Paulista, Marília. (Orientação: Maria do Rosário Longo Mortatti).

8. GONÇALVES, Rodrigo Tadeu. Perpétua prisão órfica ou Ênio tinha três corações: o relativismo lingüístico e o aspecto criativo da linguagem. 2008. 240 f. Tese (Doutorado em Lingüística) - Setor de Ciências Humanas, Letras e Arte. Universidade Federal do Paraná, Curitiba. 


\section{INSTITUIÇÕES, ACERVOS E CATÁLOGOS DIGITAIS E BASES DE DADOS DE BIBLIOTECAS UNIVERSITÁRIAS DISPONÍVEIS ON-LINE CONSULTADOS Acervos}

Acervo do Grupo de Pesquisa "História do Ensino de Língua e Literatura do Brasil" — Faculdade de Filosofia e Ciências - Universidade Estadual Paulista — Marília-SP.

Biblioteca da Faculdade de Educação (FE) — Universidade Estadual de Campinas — Campinas-SP.

Biblioteca do Instituto de Estudos Brasileiros (IEB) - Universidade de São Paulo — São Paulo-SP.

Biblioteca do Instituto de Estudos Lingüísticos (IEL) - Universidade Estadual de Campinas Campinas-SP.

CEDAE - Centro de Documentação Cultural "Alexandre Eulálio" - Instituto de Estudos da Linguagem - Universidade Estadual de Campinas — Campinas-SP.

Serviço de Biblioteca da Faculdade de Ciências e Letras - Universidade Estadual Paulista Araraquara-SP.

Serviço de Biblioteca da Faculdade de Filosofia e Ciências - Universidade Estadual Paulista Marília-SP.

Serviço de Biblioteca do Instituto de Biociências, Letras e Ciências Exatas (IBILCE) — Universidade Estadual Paulista - São José do Rio Preto-SP.

Serviço de Biblioteca e Documentação da Faculdade de Educação - Universidade de São Paulo São Paulo-SP.

Serviço de Biblioteca e Documentação da Faculdade de Filosofia, Letras e Ciências Humanas Universidade de São Paulo - São Paulo-SP.

\section{Bases de dados de bibliotecas universitárias disponíveis on-line}

Base de dados Acervus - Sistema de Bibliotecas da Universidade Estadual de Campinas.

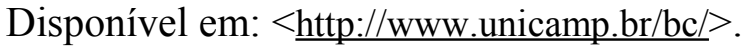

Base de dados Athena - Faculdade de Filosofia e Ciências - Universidade Estadual Paulista. Disponível em: <http://www.athena.biblioteca.unesp.br/F?RN=672374846>.

Base de dados CEDAE - Centro de Documentação "Alexandre Eulálio" - Faculdade de Educação - Universidade Estadual de Campinas. Disponível em: $<$ http://www.cedae.iel.unicamp.br/biblioteca/catalogos.php $>$.

Base de dados Dedalus - Faculdade de Educação - Universidade de São Paulo. Disponível em: <http://dedalus.usp.br:4500/ALEPH/por/USP/USP/DEDALUS/START>.

Base de dados de Unidades de I\&D - Universidade do Porto/Portugal. Disponível em: $<$ http://www.fct.mctes.pt/unidades/index.asp?p=3\&u=22>.

Base de dados Minerva - Universidade Federal do Rio de Janeiro. Disponível em: $<$ http://fenix.ufrj.br:4505/ALEPH $>$. 
Base de dados Scientifc Eletronic Library Online - SCIELO - Disponível em: $<$ http://www.scielo.br/scielo.php?>. 
APÊNDICE B

Referências de textos mais citados por J. W. Geraldi em textos que tematizam o ensino de língua portuguesa:

um instrumento de pesquisa 
LUZIA DE FÁTIMA PAULA

REFERÊNCIAS DE TEXTOS MAIS CITADOS POR J. W. GERALDI EM TEXTOS QUE TEMATIZAM O ENSINO DE LÍNGUA PORTUGUESA: UM INSTRUMENTO DE PESQUISA

Universidade Estadual Paulista

Faculdade de Filosofia e Ciências

Campus de Marília

Marília - SP

Outubro de 2009 


\section{SUMÁRIO}

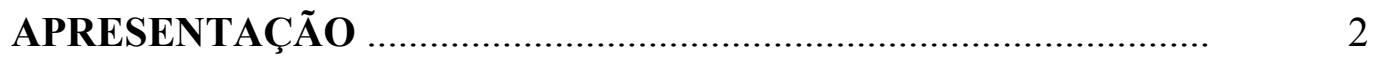

1. EM LIVROS ...................................................................... 4

1.1Em Livros - como autor .................................................. 4

1.2 Em Livros - como organizador/coordenador ................................. 8

2. EM CAPÍTULOS DE LIVROS - como autor ................................... 9

3. EM ARTIGOS EM PERIÓDICOS ................................................ 9

3.1 Em Artigos em periódicos - como autor ....................................... 9

3.2 Em Artigos em periódicos - como co-autor .................................... 11

4. EM TEXTOS EM ANAIS DE EVENTOS - como autor ........................ 12

Instituições, acervos e catálogos digitais e bases de dados de 13 bibliotecas universitárias disponíveis on-line consultados. 


\section{APRESENTAÇÃO}

Este instrumento de pesquisa resulta de procedimentos de localização, recuperação, reunião, seleção e ordenação de textos de João Wanderley Geraldi, que, desde 1978 vem-se destacando no âmbito do ensino de língua portuguesa no Brasil, em decorrência do pioneirismo de sua proposta para esse ensino, centrada no interacionismo lingüístico.

Como já informado, localizei 224 referências de textos ${ }^{179}$ de Geraldi no instrumento de pesquisa intitulado "Bibliografia de e sobre João Wanderley Geraldi: um instrumento de pesquisa" (22 f.), que se encontra no Apêndice A desta tese. A publicação desses textos ocorre do ano de 1978, ano do primeiro texto publicado pelo autor, a 2008, ano determinado para o encerramento da recuperação de documentos para esta pesquisa.

Conforme anteriormente informado, as 224 referências de textos de Geraldi publicados no período compreendido entre 1978 e 2008 estão divididos entre os seguintes tipos de textos e formas de participação: livros (como autor, organizador, coordenador, coautor): 15; capítulos de livros (como autor, co-autor): 31; artigos em periódicos (como autor, co-autor): 63; entrevistas (como autor, co-autor): 24; textos em anais de eventos (como autor, co-autor): 22; artigos em jornais (como autor, co-autor): 4; resenhas: 9; prefácios e apresentações de livros: 22; quarta capa e orelhas de livros: 5; traduções: 12; periódico: 1; dissertação, teses e memoriais acadêmicos: 6; e vídeos: 9.

Dos textos publicados, muitos deles sob diferentes tipos e em diferentes periódicos e em diferentes anos, considero as primeiras edições de cada título publicado.

Como anteriormente abordado, os textos de Geraldi tematizam diversas questões: aspectos gerais da língua, da linguagem e da lingüística; importantes pensadores para a educação brasileira (os brasileiros Paulo Freire, Antonio Candido e Carlos Franchi, e os estrangeiros Mikhail Bakhtin, Lev Vigotski ${ }^{180}$ e Gregory Bateson); educação em geral; pensamento científico; traduções de textos sobre teorias vigentes no Brasil; dentre outras questões discutidas que envolvem reflexões acerca de aspectos linguísticos e educacionais e, com destaque em quantidade, os textos que tematizam diretamente o ensino de língua portuguesa, incluindo a fase inicial desse ensino, a alfabetização.

\footnotetext{
${ }_{179}$ Ressalto que o total de textos de Geraldi presente neste instrumento de pesquisa inclui apenas a primeira edição de cada título publicado, contando novamente o texto quando o mesmo título é publicado sob outro tipo de texto.

${ }^{180} \mathrm{O}$ trabalho de Lev Vigotski e Gregory Bateson foram tematizados recentemente no livro Transgressões convergentes: Vigotski, Bakhtin, Bateson (2006), de Geraldi em co-autoria com Bernd Fichtner e Maria Benites, publicado pela editora Mercado de Letras.
} 
Dado o objetivo previsto para a pesquisa de que resultou esta tese de doutorado: compreender as idéias lingüísticas constitutivas do pensamento de Geraldi sobre o ensino de língua portuguesa, destaco especialmente os textos de Geraldi que tematizam diretamente o ensino de língua portuguesa e que apresentam referências bibliográficas dos textos citados por Geraldi: livros (autor, coordenador, organizador): 4; capítulos de livros (autor): 6; artigos em periódicos: (autor, co-autor): 9 e textos em anais de eventos (autor): 2, totalizando 21 textos, os quadros apresento abaixo, no Quadro 1.

\section{Quadro 1 - Textos de J. W. Geraldi que tematizam o ensino de língua portuguesa e que apresentam referências bibliográficas}

\begin{tabular}{|c|c|}
\hline TIPO DE TEXTO & QUANTIDADE \\
\hline Livros (autor, coordenador, organizador) & 4 \\
\hline Capítulos de livros (autor) & 6 \\
\hline Artigos em periódicos (autor, co-autor) & 9 \\
\hline Textos em anais de eventos (autor) & 2 \\
\hline TOTAL & 21 \\
\hline
\end{tabular}

Para efeitos de realização da pesquisa que resultou neste instrumento de pesquisa, consultei toda a produção de $\mathrm{J}$. W. Geraldi, os memoriais acadêmicos do autor e o seu currículo, que consta no Sistema de Currículos Lattes, assim como acervos, instituições e sites do Brasil e do exterior.

As referências bibliográficas desses textos, assim como as respectivas referências bibliográficas que neles se apresentam, encontram-se a seguir, por tipo de texto e ordem cronológica de publicação.

\section{EM LIVROS}




\subsection{Em livros - como autor}

1. GERALDI, João Wanderley. Portos de passagem. São Paulo: Martins Fontes, 1991. 252 p. ${ }^{181}$

ALMEIDA, Ciriene Magalhães. Predicação metafórica e gerativismo. Cadernos de estudos lingüisticos, Campinas, n. 17, p. 147-162, 1989.

ALMEIDA, Júlia Lopes de. Histórias de nossa terra. 7. ed. Rio de Janeiro: Francisco Alves, 1911.

ANGENOT, Marc; ROBIN, Régine. Penser le discours social: problématique nouvelles et incertitudes actuelles - un dialogue entre 'A' et 'B'”. Sociocriticism, v. VIII, ano 2, n. 6, p. I-XII, 1987.

ANIS, Jacques. Litteralement and dans plusieurs sens: le texte. Linx, n. 12, p. 25-36, 1985.

ARROYO, Miguel G. A formação, direito dos profissionais da educação escolar. Política de capacitação dos profissionais da educação, Belo Horizonte: FAE/IRHJP, p. 35-71, 1989. (Departamento Técnico-Pedagógico).

AUTHIER-REVUZ, Jacqueline. Hétérogénéité montrée et hétérogénéité constitutive: éléments pour une approche de l'autre dans le discours. Revue de Linguistique, DRLAV, n. 26, p. 91-151, 1982.

BACK, Eurico. Fracasso do ensino de português: proposta de solução. Petrópolis: Vozes, 1987.

BAKHTIN, Mikhail. Marxismo e filosofia da linguagem. Tradução de Michel Laud e Yara Frateschi Vieira. 2. ed. São Paulo: Hucitec, 1981. (Original de 1929).

BARBOSA, Rui. Métodos e programa escolar: reforma do ensino primário e várias instituições complementares da instrução pública. Rio de Janeiro: Ministério da Educação e Saúde, v. X, tomo II, 1946. (Obras Completas de Rui Barbosa). (Original de 1883).

BEGUE, Dominique. Enonciation, temporalisation et actes de langage indirectes. Linx, n. 10, p. 119-134, 1984.

BELTRAN, José Luiz. O ensino de português: intenção e realidade. São Paulo: Moraes, 1989.

BENVENISTE, Émile. Da subjetividade na linguagem. In: BENVENISTE, Émile. Problemas de lingüística geral. Tradução de Maria da Glória Novak e Luiza Néri. São Paulo: Companhia Editora Nacional/EDUSP, 1966. v. I. (Original de 1958).

BENVENISTE, Émile. O aparelho formal da enunciação. In: BENVENISTE, Émile. Problemas de lingüistica geral. Tradução de Marco Antônio Escobar. Campinas: Pontes, 1989. v. II. (Original de 1970).

BERNARDO, Gustavo. A redação inquieta. Rio de Janeiro: Globo, 1988.

BITTENCOURT, Solange Torres. Livro didático de português: diagnóstico de uma realidade. 1981. Dissertação (Mestrado) - Universidade Federal do Paraná.

BIVAR, Maria de Fátima. Ensino primário e ideologia. 2. ed. Lisboa: Seara Nova, 1971.

BONAZZI, Mariza; ECO, Umberto. Mentiras que parecem verdades. Tradução de Giacomina Faldini. São Paulo: Summus, 1980. (Original de 1972).

BORILLO, Andrée. Discours ou metadiscours? Revue de Linguistique, DRLAV, n. 21, p. 47-61, 1985.

CAGLIARI, Luis Carlos. Marcadores prosódicos na escrita. In: ESTUDOS LINGÜÍSTICOS, 18., 1989. Lorena. Seminários do grupo de estudos lingüisticos: anais. Lorena: Prefeitura Municipal de Lorena/GEL, p. 195-203, 1989.

CARVALHO, José Gonçalo Herculano de. A difusão da língua portuguesa na África. Luanda: Universidade de Luanda, 1971.

CHEONG, K-S. Les guillemets, marqueurs de reformulation modules. Modèles linguistiques, n. 19, p. 71-81, 1988.

COHEN, Ted. Illocutions an perlocutions. Foundations of language, n. 9, p. 492-503, 1973.

COMENIUS, João Amós. Didactica Magna. 2. ed. Tradução, introdução e notas de Joaquim Ferreira Gomes. Lisboa: Fundação Calouste Gulbenkian, 1976. (Original de 1627).

COQUET, J-C. Les discours et son sujet. Paris: Klincksiek, 1984 v. I .

COUDRY, Maria Irma H. Diário de Narciso: discurso e afasia. São Paulo: Martins Fontes, 1988

COUDRY, Maria Irma H.; MORATO, Edwiges Maria. A ação reguladora da interlocução e de operações epilingüísticas sobre objetos lingüísticos. Cadernos de estudos lingüisticos, Campinas, n. 15, p. 117-135, 1988.

DASCAL, Marcelo; WEIZMANN, Elda. Contextual exploitation of interpretation clues in text understanding: an integrated model. In: PAPI, Marcella Bertulecciii; VERSCHUEREN, Jef. (Eds.). The pragmatic perspective: selected papers from the 1985. Amsterdam: Internacional Pragmatics Conference, John Benjamins, 1985.

LEMOS, Cláudia T. G. Sobre aquisição de linguagem e seu dilema (pecado) original. Boletim da Abralin, n. 3, p. 97-126, set. 1982.

DESCHÊNES, André-Jacques. Le role des connaissences initiales dans l'acquisition d'informations nouvelles à l'aide de texts. European Journal of Psycology of Education, v. III, n. 2, p. 137-143, 1988.

DORFMAN, Ariel; MATTELART, Armand. Para ler al pato Donald. Buenos Aires: Siglo XXI, 1972.

DOUAY, Maryne. De l' apresse a la pub: l'ambiguité entre em jeu. Modeles linguistiques, n. 19, p. 21-31, 1988.

DUCROT, Oswald. Princípios de semântica lingüiśtica: dizer e não dizer. Tradução de Carlos Vogt et al. São Paulo: Cultrix, 1977. DUCROT, Oswald. Les échelles argumentatives. In: DUCROT, Oswald. La preuve et le dire. Paris: Mame, 1973.

DUCROT, Oswald. O dizer e o dito. Tradução de Eduardo Guimarães et al. Campinas: Fontes, 1987. (Original de 1984).

DUPUY, Jean-Paul. 'Common knowledge' et sens-commun. Cahiers du Sciences cognitives et science economique, C.R.E.A., n. 11, p. 11$51,1988$.

ECO, Umberto. Os novos filósofos. In: ECO, Umberto. Viagem na irrealidade cotidiana. Tradução de Aurora Fornoni Bernardini e Homero Freitas de Andrade. Rio de Janeiro: Nova Fronteira, 1984. p. 309-313. (Original de 1977).

ECO, Umberto. Lector in fabula. Tradução de Atilio Cancian. São Paulo: Perspectiva, 1986. (Original de 1979).

EHLICH, Konrad. Discurso escolar: diálogo? Cadernos de estudos lingüísticos, Campinas, n. 11, p. 145-172, 1986.

Escola de Barbiana. Carta a uma professora, pelos rapazes da escola de Barbiana. 3. ed. Lisboa: Editorial Presença, s. d.

FALL, Khadiyatoulah. Linguistique et didactique de la lecture. Langues et linguistique, n. 14, p. 71-88, 1988.

FIALA, Pierre. Polyphonie et stabilisation de la référence: l'altérité dans le texte politique. In: TRAVAUX DU CENTRE DES RECHERCHES SÉMIOLOGIQUES, 50., 1986, Actes du Colloque Dialogisme et Polyphonie, 1986. p. 14-46.

FOUCAULT, Michel. A ordem do discurso. Tradução de Sírio Possenti, revisão de Dinarte Belatto e José Crippa. Cadernos da FIDENE, Ijuí, 1973. (Original de 1971).

FRACALANZA, Hilário et al. (Org.). O que sabemos sobre livro didático: catálogo analítico. Universidade Estadual de Campinas, Biblioteca Central-Serviço de Informação sobre livro didático, Campinas: Editora da UNICAMP/UNESP, 1989.

FRANCHI, Carlos. Linguagem: atividade constitutiva. Almanaque, Cadernos de Literatura e Ensaio, São Paulo, Brasiliense, n. 5, p. 9-27, 1977.

FRANCHI, Carlos. Reflexões sobre a hipótese da modularidade da mente. Boletim da Abralin, n. 8, p. 17-35, 1986.

FRANCHI, Carlos. Criatividade e gramática. São Paulo: CENP/Secretaria de Educação do Estado de São Paulo, 1988.

${ }^{181}$ Como mencionado anteriormente, esse livro de Geraldi resulta de sua tese de doutorado, com exceção de um capítulo. Por esse motivo, neste instrumento de pesquisa, não ordeno as referências bibliográficas presentes em sua tese de doutorado, já que não apresentam alterações com relação ao livro. 
FRANCHI, Carlos. Repensar o ensino da gramática-debate. In: HUBNER, Regina Maria. (Org.). Quando o professor resolve. São Paulo: Edições Loyola, 1989.

FRANCHI, Eglê. E as crianças eram dificeis.... a redação na escola. São Paulo: Martins Fontes, 1984.

FREIRE, Paulo. Pedagogia del oprimido. Buenos Aires: Siglo XXI, 1970.

FREIRE, Paulo. A importância do ato de ler. São Paulo: Cortez, 1982.

GADET, Françoise; PÊCHEUX, Michel. La langue introuvable. Paris: Maspero, 1981.

GAMBIER, Yves. Interaction verbale et production de sens. Cahiers de linguistique sociale, n. 13, p. 19-103, 1988.

GERALDI, João Wanderley. Subsídios metodológicos para o ensino de língua portuguesa no $1^{\mathrm{o}}$. grau: $5^{\mathrm{a}}$. a $8^{\mathrm{a}}$. séries. Cadernos da FIDENE, Ijuí, n. 18, 1981.

GERALDI, João Wanderley. (Org.). O texto na sala de aula. Cascavel: Assoeste, 1984.

GERALDI, João Wanderley. Prática de produção de textos na escola. Trabalhos em lingüística aplicada, Campinas, n. 7, p. 23-28, 1986.

GIL NETO, Antônio. A produção de textos na escola. São Paulo: Edições Loyola, 1988.

GNERRE, Maurizzio. Linguagem, escrita e poder. São Paulo: Martins Fontes, 1985.

GRANGER, Gilles Gaston. O problema das significações. In: GRANGER, Gilles Gaston. Filosofia do estilo. Tradução de Scarlet Zerbetto Marton. São Paulo: Perspectiva, 1974. p. 133-168. (Original de 1968).

GRANGER, Gilles Gastón. A razão. Tradução de Lúcia Seixas Prado e Bento Prado. São Paulo: Difel, 1969.

GRÉSILLON, Almuth. Ambiguité et double sens. Modèles linguistiques, n. 19, p. 9-20, 1988.

HABERMAS, Jürgen. Conhecimento e interesse. In: HABERMAS, Jürgen. Técnica e ciência como "ideologia". Lisboa: Edições, n. 70 , 1987. p. 129-147. (Original de 1965).

HABERMAS, Jürgen. Trabalho e interacção. In: HABERMAS, Jürgen. Técnica e ciência como “ideologia”. Lisboa: Edições, n. 70, 1987. HILGERT, José Gaston. A paráfrase: um procedimento de constituição do diálogo. 1989. Tese (Doutorado), Universidade de São Paulo, São Paulo.

HUBNER, Regina Maria. (Org.). Quando o professor resolve. São Paulo: Edições Loyola, 1989.

ILARI, Rodolfo. A lingüística e o ensino da língua portuguesa. São Paulo: Martins Fontes, 1985.

LAHUD, M. A semiologia segundo Granger. Discurso, São Paulo, n. 6, p. 105-131, 1975.

LAJOLO, Marisa. Usos e abusos da literatura na escola: Bilac e a literatura escolar na República Velha. Rio de Janeiro: Globo, 1982.

LAJOLO, Marisa. O que é literatura. São Paulo: Brasiliense, 1982.

LEGRAND-GELBER, Régine. De l'homogéneité du dialogue pédagogique a l'hétérogenéité des interactions didactiques. Cahiers de linguistique sociale, n. 12, p. 86-88, 1988.

LEGRAND-GELBER, Régine. Pratiques 'meta' et interacions verbales en classe: reflexions pour une sociolinguistique. Cahiers de linguistique sociale, n. 14, p. 17-32, 1989.

LOMBARDO-RADICE, Giuseppe. El ideal de una educación lingüística. In: LOMBARDO-RADICE, Giuseppe. Lengua y gramática: lecciones de didáctica. Barcelona: Labor, 1933. (Original de 1919).

LUFT, Celso Pedro. Língua e liberdade: por uma nova concepção da língua materna e seu ensino. Porto Alegre: L\&PM, 1985.

MACKENZIE, Ian. Le texte, le lecteur et la reference. Cahiers de linguistique sociale, DLSL, n. 7, p. 41-58, 1988.

MANACORDA, Mário A. História da educação: da Antigüidade aos nossos dias. Tradução de Gaetano Lo Mônaco. São Paulo: Cortez/Autores Associados, 1989.

MARCUSCHI, Luis Antonio. A propósito das estratégias jornalísticas. Série Estudos, Uberaba, n. 8, p. 18-23, 1982.

MARCUSCHI, Luis Antonio. Análise da conversação. São Paulo: Ática, 1986.

MARINHO, A. A. C. Repensar o ensino da gramática: debate. In: HUBNER, Regina Maria. (Org.). Quando o professor resolve. São Paulo: Edições Loyola, 1989.

MAURO, Tullio de. Une introduction a la sémantique. Tradução de Louis-Jean Calvet. Payot. 1969. (Original de 1966).

MAZZOTTI, Marlene Adorni. O livro didático como categoria de investigação a realidade escolar. 1986. Dissertação (Mestrado) UFSCar, São Carlos.

MIÉVILLE, Denis. Description et représentation. Travaux du Centre de Recherches Sémiologiques, n. 55, p. 147-164, 1988.

MITTWOCH, Anita. Grammar and illocutionary force. Lingua, ano 40, n. 1, p. 21-42, 1976.

MOLINA, Olga. Quem engana quem: professor x livro didático. Campinas: Papirus, 1987.

MONTESQUIEU. Cartas persas. Tradução de Mário Barreto. Belo Horizonte: Ed. Itatiaia, 1960. (Original de 1721).

MOTSCH, William. Situational context and illocutinary force. In: SEARLE, John R. et al. (ed.). Speech act theory and pragmatics. Dodrecht: Holland; D. Reidel Publishing Company, 1980. p. 155-168.

NOSELLA, Maria de Lourdes Chagas Deiró. As belas mentiras. São Paulo: Cortez e Moraes, 1979.

OLIVEIRA, Maria Lisboa de. Reconstruindo a escola pública. In: POLÍTICA DE CAPACITAÇÃO DOS PROFISSIONAIS DA EDUCAÇÃO. Departamento Técnico-Pedagógico. Belo Horizonte: FAE/IRHJP, julho de 1989. p. 91-103. (Entrevista concedida a técnicos do IRHJP).

ORLANDI, Eni Pulcinelli. O discurso da história para a escola. In: ORLANDI, Eni Pulcinelli. A linguagem e seu funcionamento. São Paulo: Brasiliense, 1983. p. 51-71.

ORLANDI, Eni Pulcinelli. As histórias das leituras. Leitura: teoria e prática, Campinas, ano 3, n. 3, p. 7-9, 1984.

ORLANDI, Eni Pulcinelli. Análise do discurso e leitura. São Paulo: Cortez/Autores Associados; Campinas: Editora da UNICAMP, 1988.

OSAKABE, Haquira. Argumentação e discurso político. São Paulo: Kairós, 1979.

OSAKABE, Haquira. Considerações em torno do acesso ao mundo da escrita. In: ZILBERMAN, Regina. (Org.). A leitura em crise na escola. Porto Alegre: Mercado Aberto, 1982.

OSAKABE, Haquira. Ensino de gramática e ensino de literatura: a propósito do texto de Lígia Chiappini Moraes Leite. Linha d'água, São Paulo, n. 6, p. 57-62, 1988.

PARRET, Herman. Les théories linguistiques peuvent-elles être idéologiquement neutres? Ou l'histoire d'un démon qui s'appele véridiction. In: CONGRÈS INTENATIONAL STRUTTURE SEMIOTICHE E STRUTTURE IDEOLOGICHE. décembre 1976, Université de Palerme. Actes...

PARRET, Herman. Les passions: essai sur la mise em discours de la subjetictivité. Liège: Pierre Mardaga Editeur, 1986.

PARRET, Herman. Os objetivos e o domínio da pragmática. Enunciação e pragmática, Campinas, p. 15-32, 1988.

PÊCHEUX, Michel. Sur la (dé)construction des théories linguistiques. Revue de Linguistique, DRLAV, n. 27, p. 1-24, 1982.

PÉCORA, Alcir A. Problemas de redação. São Paulo: Martins Fontes, 1983.

PERUS, F. Cultura, ideología, formaciones ideológicas y practicas discursivas. Discurso, Cuadenos de Teoría y Analysis, ano 2, n. 5, 1984. PETÖFI, J. S. ; KAYSER, H. Les actes de langage et l'interprétation sémantique: lê role des expressions performatives et constituantes de mondes dans l'interprétation de textes. Linguistique et semiologie, n. 5, p. 137-176, 1978.

PINÕN, Nélida. A república dos sonhos. Rio de Janeiro: Francisco Alves, 1984.

POP, Liana. Vers une grammaire des marqueurs pragmatiques: domaine roumain-français. Revue roumaine de linguistique, tome XXXIV, n. 3, p. 217-229, 1989.

POSSENTI, Sírio. Discurso: objeto da lingüística. Série Estudos, Uberaba, n. 6, p. 9, .

POSSENTI, Sírio. Discurso e texto: imagem e/de constituição. In: ORLANDI, Eni Pulcinelli. (Org.). Sobre a estruturação do discurso. Campinas: IEL/UNICAMP, 1981. p. 39-62. 
POSSENTI, Sírio. Discurso, estilo e subjetividade. São Paulo: Martins Fontes, 1988.

POSSENTI, Sírio. Questões de Análise do Discurso. In: SIMPÓSIO TESES RECENTES DE DOUTORAMENTO EM LINGÜÍSTICA, 40., 1988, São Paulo. Reunião Anual da SBPC.

POSSENTI, Sírio. A leitura errada existe. In: ESTUDOS LINGÜÍSTICOS, 19., 1989, Lorena. Seminários do grupo de estudos lingüisticos: anais, 1989. p. XXXVII.

PROUST, Michel. Sobre a leitura. Tradução de Carlos Vogt. Campinas: Pontes, 1989. (Original de 1905).

RÉCANATI, François. La transparência y la enunciación. Tradução de Cecília E. Hidalgo. Buenos Aires: Hachette, 1979.

ROSSI-LANDI, Ferruccio. A linguagem como trabalho e como mercado: uma teoria da produção e da alienação lingüísticas. Tradução de Aurora Fornoni Bernardini. São Paulo: Difel, 1985. (Original de 1968).

ROVENTA-FRUMUSANI, Daniela. Argumentation, néorhétorique et théorie de l'action. Revue roumaine de linguistique, ano 29, n. 3, p. 247-256, 1984.

RUIZ, Eliana Maria et al. O livro didático de língua portuguesa: didatização e destruição da atividade lingüística. Trabalhos em lingüistica aplicada, Campinas, n. 7, p. 81-88, 1986.

RUSCHEL, Leani Inês. Fotografias do cotidiano escolar: o preço da disciplina é a eterna vigilância. 1990. Dissertação (Mestrado) Faculdade de Educação, UNICAMP.

SANTOS, Maria Rosemary. A avaliação das redações escolares: alguns pressupostos ideológicos. Belo Horizonte: Editora da UFMG, 1987.

SEARLE, John. Speech acts: an essay in the philosophy of language. Cambridge: Cambridge University Press, 1969.

SECRETARIA DE EDUCAÇÃO DE MINAS GERAIS. O ensino de língua portuguesa nas escolas mineiras. Belo Horizonte, Imprensa Oficial, 1949.

SILVA, Lílian Lopes Martin da. A escolarização do leitor: a didática da destruição da leitura. Porto Alegre: Mercado Aberto, 1986.

SILVA, Lílian Lopes Martin da et al. O ensino de língua portuguesa no $1^{\circ}$ grau. São Paulo: Atual, 1986.

SIMONIN, Jenny. De le necessite de distinguer énonciateur et locuteur dans une théorie enonciative. Revue de linguistique, DRLAV, n. 30, p. 55-62, 1984.

SMITH, C. S. The vagueness of sentences in isolation. CLS, n. 13, p. 568-77, 1977.

SOARES, Magda Becker. Comunicação e expressão: ensino da língua portuguesa no $1^{\circ}$ grau. Cadernos PUC, Rio de Janeiro, n. 23, p. 7-38, 1974.

SOARES, Magda Becker. Travessia: tentativa de um discurso de ideologia. 1981. Memorial (Concurso de Professor Titular) - FAE/UFMG. (Inédito).

SOARES, Magda Becker. Linguagem e escola: uma perspectiva social. São Paulo: Ática, 1985.

TOURNIER, Michel. Sexta-feira ou os limbos do Pacifico. Tradução de Fernanda Botelho. São Paulo: Difel, 1985. (Original de 1972).

VAN DIJK, Teun. Discourse and power. University of Amsterdam, 1987. mimeo.

VIGNAUX, Georges. Le pouvoir des fables. Sociocriticismi, v. III, n. 2, 63-93, 1987.

WHITAKER-FRANCHI, Regina Célia M. Correlação entre estruturas causativas e estruturas ergativas: estudo de caso no processo de aquisição. Cadernos de estudos lingüisticos, Campinas, n. 17, p. 163-185, 1989.

WITTGENSTEIN, Ludwig. Investigações filosóficas. Tradução de José Carlos Bruni. São Paulo, abril de 1975. (Original de 1953).

ZASLAWSKY, Denis. Pronoms personnels, performatifs et actes de langage. Langue française, n. 42, p. 48

2. GERALDI, João Wanderley. Linguagem e ensino: exercícios de militância e divulgação. Campinas: ALB/Mercado de Letras, 1996. 148 p. (2. ed., 1999; 3. reimp., 2002). ${ }^{182}$

Discurso e sujeito

BAKHTIN, Mikhail. Marxismo e filosofia da linguagem. Tradução de Michel Laud e Yara Frateschi Vieira. 2. ed. São Paulo: Hucitec, 1981. (Original de 1929).

BAKHTIN, Mikhail. El problema del texto en la Lingüística, la Filologia y otras ciencias humanas. In: BAKHTIN, Mikhail. Estética de la Creacion Verbal. México: Siglo XXI, 1982. (Original de 1976).

BAKHTIN, Mikhail. El problema de los géneros discursivos. In: BAKHTIN, Mikhail. Estética de la creación verbal. México: Siglo XXI, 1978.

BENJAMIN, Walter. O narrador: considerações sobre a obra de Nikolai Leskov. In: BENJAMIN, Walter. Magia e técnica, arte e política: ensaios sobre Literatura e História da Cultura - Obras Escolhidas. São Paulo: Brasiliense, 1994. v. I. (Original de 1936).

BENVENISTE, Émile. O aparelho formal da enunciação. In: BENVENISTE, Émile. Problemas de lingüística geral. Campinas: Pontes, 1989. v. II. (Original de 1970).

BENVENISTE, Émile. Da subjetividade na linguagem. In: BENVENISTE, Émile. Problemas de lingüistica geral. São Paulo: Companhia Editora Nacional; EDUSP, 1976. v. I. (Original de 1958).

CALVINO, Ítalo. Palomar na praia: leitura de uma onda. In: CALVINO, Ítalo Palomar. Lisboa: Teorema, 1983.

CERTEAU, Michel de. Introdução geral. In: CERTEAU, Michel de. A invenção do cotidiano: artes de fazer. Petrópolis: Vozes, 1994.

(Original de 1990).

FRANCHI, Carlos. Linguagem: atividade constitutiva. Almanaque, São Paulo, Brasiliense, n. 5, 1977.

LÖWY, Michael. Ideologia. São Paulo: Cortez, 1989.

MAINGUENEAU, Dominique. Análise do discurso: a questão dos fundamentos. Cadernos de estudos lingüisticos, Campinas, n. 19 , 1990. PÊCHEUX, Michel. A Análise de Discurso: três épocas. In: GADET, Françoise; HAK, Tony. (Orgs.). Por uma análise automática do discurso: uma introdução à obra de Michel Pêcheux. Campinas: Editora da UNICAMP, 1990. (Original de 1983).

SAUSSURE, Ferdinand. Curso de Lingüística Geral. São Paulo: Cultrix, 1979. (Original de 1916).

STEINER, George. No castelo do Barba Azul: algumas notas para a redefinição da cultura. São Paulo: Cia. das Letras, 1991. (Original de 1971).

1. O ensino e as diferentes instâncias de uso da linguagem

BAKHTIN, Mikhail. Marxismo e filosofia da linguagem. Tradução de Michel Lahud e Yara F. Vieira. 2. ed. São Paulo: Hucitec, 1982.

${ }^{182}$ Esse livro resultou da tese de livre-docência de Geraldi. Por esse motivo, neste instrumento de pesquisa, não ordeno as referências bibliográficas presentes em sua tese de livre-docência. Considero, para a ordenação das referências bibliográficas presentes no livro Linguagem e ensino: exercícios de militância e divulgação (1996a), de Geraldi, a mesma ordem em que os artigos estão dispostos no livro. O artigo Discurso e sujeito não foi numerado no livro, vindo logo depois da "Introdução" e não participando da divisão em partes e, por esse motivo, não foi aqui numerado. Saliento também que o artigo sob número 8, "Ensino de gramática x reflexão sobre a língua", não possui referências bibliográficas, não constando, portanto, esse artigo neste instrumento de pesquisa. 
CANETTI, Elias. A língua absolvida: história de uma juventude. Tradução de Kurt Jahn. São Paulo: Cia das Letras, 1987.

COMENIUS, João Amós. Didactica Magna. 2. ed. Tradução, introdução e notas de Joaquim Ferreira Gomes. Lisboa: Fundação Calouste Gulbenkian, 1976. (Original de 1627).

GERALDI, João Wanderley. Portos de passagem. São Paulo: Martins Fontes, 1991.

GNERRE, Maurizzio. Linguagem, escrita e poder. São Paulo: Martins Fontes, 1985.

GRANGER, Gilles Gaston. O problema das significações. In: GRANGER, Gilles Gaston. Filosofia do estilo. Tradução de Scarlet A. Marton. São Paulo: Perspectiva, 1974. (Original de 1968).

LEGRAND-GELBER, Régine. De l'homogénéité du dialogue pédagogique a l'hétérogénéité des interactions didactiques. Cahiers de Linguistique Sociale, n. 12, p. 86-88, 1988.

LIBÂNEO, José Carlos. Democratização da Escola Pública: a pedagogia crítico-social dos conteúdos. São Paulo: Loyola, 1987.

LOVISOLO, Hugo. Política cultural e escola: o momento atual: junção de enfoques contrapostos? In: SIMPÓSIO SOBRE POLÍTICA

CULTURAL E ESCOLA, 5., CBE, Brasília, agosto de 1988.

MANACORDA, Mário A. História da Educação: da Antigüidade aos nossos dias. Tradução de Caetano Lo Mônaco. São Paulo: Cortez/Autores Associados, 1989.

2. O ensino da unidade na diversidade lingüístico-cultural

GERALDI, João Wanderley. Portos de passagem. São Paulo: Martins Fontes, 1991.

GNERRE, Maurizzio. Linguagem, escrita e poder. São Paulo: Martins Fontes, 1985.

KATO, Mary. No mundo da escrita: uma perspectiva psicolingüística. São Paulo: Ática, 1986.

OSAKABE, Haquira. Considerações em torno do acesso ao mundo da escrita. In: ZILBERMAN, Regina. (Org.). A leitura em crise na escola. Porto Alegre: Mercado Aberto, 1982.

SOARES, Magda Becker. Linguagem e escola: uma perspectiva social. São Paulo: Ática, 1986.

3. Construção de um novo modo de ensinar/aprender a Lingua Portuguesa

BAKHTIN, Mikhail. Observações sobre a epistemologia das Ciências Humanas. In: BAKHTIN, Mikhail. Estética da criação verbal. São Paulo: Martins Fontes, 1992. (Original de 1974).

GADOTTI, Moacir. A escola e a pluralidade de meios. Caderno Pedagógico, Rio de Janeiro, n. 1, novembro 1993.

OSAKABE, Haquira. Considerações em torno do acesso ao mundo da escrita. In: ZILBERMAN, Regina. (Org.). Leitura em crise na escola: as alternativas do professor. Porto Alegre: Mercado Aberto, 1982.

SMOLKA, Ana Luiza Bustamante. A criança na fase inicial da escrita: a alfabetização como processo discursivo. São Paulo/Campinas: Cortez; Editora da UNICAMP, 1988.

4. A leitura em momentos de crise social

ANDRADE, Carlos Drummond de. Mãos Dadas. In: BARATA, Manoel Sarmento. Canto melhor: uma perspectiva da Poesia Brasileira. Rio de Janeiro: Paz e Terra, 1969.

ULER, Marcelo. Sangue dos Inocentes. Veja, 14 jul. 1993.

CANETTI, Elias. A língua absolvida: história de uma juventude. Tradução de Kurt Jahn. São Paulo: Cia. Das Letras, 1987.

CAPINAN, José Carlos. Inquisitorial. In: BARATA, Manoel Sarmento. Canto melhor: uma perspectiva da poesia brasileira. Rio de Janeiro: Paz e Terra, 1969.

DANTAS, Francisco J. C. Coivara da Memória. São Paulo: Estação Liberdade, 1991.

FRANCISCATO, Carlos. Corrupção: punição de PC começa pelo crime menor. Zero hora, Porto Alegre, 11 jul. 1993.

FREIRE, Paulo. Professora sim, tia não: carta a quem ousa ensinar. São Paulo: Olho d'água, 1993.

OSAKABE, Haquira. Ensino de gramática e ensino de literatura: a propósito do texto. Linha d'água, Revista da APLL, São Paulo, 1988.

SCHWARTZ, Roberto. Nacional por subtração: que horas são? São Paulo: Cia. Das Letras, 1987.

5. Políticas de inclusão em estruturas de exclusão

BAKHTIN, Mikhail. A cultura popular na Idade Média e no Renascimento. São Paulo: Hucitec, 1987.

BAKHTIN, Mikhail. Estética da criação verbal. São Paulo: Martins Fontes, 1992.

BARATA, Manoel Sarmento. Canto melhor: uma perspectiva da poesia brasileira. Rio de Janeiro: Paz e Terra, 1969.

BRECHT, Bertold. Poemas e canções. Seleção e tradução de Geir Campos. Rio de Janeiro: Civilização Brasileira, 1966.

FOUCAMBERT, Jean. A leitura em questão. Porto Alegre: Artes Médicas, 1994.

FREIRE, Paulo. A importância do ato de ler. São Paulo: Cortez; Autores Associados, 1982.

GERALDI, João Wanderley. (Org.). O texto na sala de aula: leitura e produção. Cascavel: Assoeste, 1984.

GERALDI, João Wanderley. Portos de passagem. São Paulo: Martins Fontes, 1991.

GINZBURG, Carlo. O queijo e os vermes. São Paulo: Cia das Letras, 1987.

ILLICH, Ivan. A plea for research on lay literacy. In: OLSON, David e TORRANCE, M. (Eds.). Literacy and orality. Cambridge: Cambridge Univ. Press, 1991.

KRAMER, Sônia. A formação do professor como leitor e construtor do saber. In: MOREIRA, Antonio Flávio. (Org.). Conhecimento educacional e formação do professor. Campinas: Papirus, 1994.

KUNDERA, Milan. A insustentável leveza do ser. Rio de Janeiro: Nova Fronteira, 1985

MAGNANI, Maria do Rosário Mortatti. Leitura, literatura e escola: sobre a formação do gosto. São Paulo: Martins Fontes, 1989.

RAMA, Angel. A cidade das letras. São Paulo: Brasiliense, 1985.

SARAMAGO, José. O evangelho segundo Jesus Cristo. São Paulo: Cia. Das Letras, 1991.

SNYDERS, Georges. Para onde vão as pedagogias não-directivas? Lisboa: Moraes, 1974.

SNYDERS, Georges. A alegria na escola. São Paulo: Manole, 1988.

VYGOTSKY, Lev. Pensamento e linguagem. Lisboa: Antídoto, 1979.

WITTGENSTEIN, Ludwig. Investigações filosóficas. São Paulo: Abril, 1975

6. A propósito do outro: imagem, construção e cumplicidade

BORDIEU, Pierre. Lecture, lecteurs, letters, literature. In: BORDIEU, Pierre. Choses dites. Paris: Minuit, 1987.

ECO, Umberto. O Leitor-Modelo. In: ECO, Umberto. Lector in fabula. Tradução de Atílio Cancian. São Paulo: Perspectiva, 1986.

LACERDA, Nilma G. Manual de Tapecaria. Rio de Janeiro: Philobilbion, 1986.

REY, Marcos. Ópera de sabão. Porto Alegre: L\&PM, 1980.

SEARLE, John R. The logical status of fictional discourse. In: SEARLE, John R. Expression and meaning. Cambridge: Cambridge University Press, 1979.

TOURNIER, Michel. Sexta-feira ou os limbos do Pacífico. Tradução de Fernanda Botelho. São Paulo: Difel, 1985.

7. Algumas funções da leitura na formação de técnicos

GERALDI, João Wanderley. Portos de passagem. São Paulo: Martins Fontes, 1991

GRAMSCI, Antonio. Os intelectuais e a organização da cultura. 2. ed. Rio de Janeiro: Civilização Brasileira, 1978.

MANACORDA, Mário A. História da Educação: da Antigüidade aos nossos dias. São Paulo: Cortez; Autores Associados, 1989.

9. A escrita como trabalho: operações e meta-operações de construção de textos

BAKHTIN, Mikhail. Marxismo e filosofia da linguagem. Tradução de Michel Laud e Yara Frateschi Vieira. 2. ed. São Paulo: Hucitec, 1981. (Original de 1929). 
FIAD, Raquel Salek. Operações Lingüísticas presentes na reescrita de textos. In: CONGRESSO INTERNACIONAL DA ALFAL, 9. , Campinas, agosto de 1990. (Comunicação apresentada).

GERALDI, João Wanderley. Portos de passagem. São Paulo: Martins Fontes, 1991.

10. Da interpretação de processos indiciados nos produtos

PÊCHEUX, Michel. O Discurso: estrutura ou acontecimento. Campinas: Pontes, 1990. (Original de 1988).

GINZBURG, Carlo. Chaves do mistério: Morelli, Freud e Sherlock Holmes. In: ECO, Umberto e SEBEOK, A. O signo de três. São Paulo: Perspectiva, 1991. p. 89-129. (Original de 1979).

BOURDIEU, Pierre. Introdução a uma sociologia reflexiva. In: BORDIEU, Pierre. O poder simbólico. Lisboa: Difel; Rio de Janeiro: Bertrand, 1989. (Original de 1987).

SERRANI, Silvana Mabel. A linguagem na pesquisa sociocultural: um estudo da repetição na discursividade. Campinas: Editora da UNICAMP, 1993.

\subsection{Em livros - como organizador/coordenador}

1. GERALDI, João Wanderley. (Org.). O texto na sala de aula: leitura \& produção. Cascavel: Assoeste, 1984.125 p. (2. ed., 1985; 3. ed., 1987; 5. ed., 1990; 7. ed., 1991) ${ }^{183}$.

5. Concepçôes de linguagem e ensino de português

GNERRE, Maurizzio. Linguagem e poder. Subsídios à proposta curricular de Língua Portuguesa para o $2^{\circ}$ grau: variação lingüística e ensino da língua materna. Secretaria de Estado da Educação, São Paulo, v. IV, 1978.

MELLO, Guiomar Namo de. Fatores intra-escolares como mecanismos de seletividade no ensino de $1^{\circ}$ grau. Educação \& Sociedade, n. 2, p. 70-77, 1979.

SOARES, Magda Becker. Aprendizagem da língua materna: problemas e perspectivas. Em aberto, ano 2, n. 12, 1983.

8. Prática da leitura de textos na escola

AUTHIER-REVUZ, Jacqueline. Hétérogénéité montrée et hétérogénéité constitutive: éléments pour une approche de l'autre dans lê discours. Revue de Linguistique, DRLAV, n. 26, p. 91-151, 1982.

BENVENISTE, Émile. Problemas de lingüistica geral. São Paulo: São Paulo: Companhia Editora Nacional/EDUSP, 1976. (Original de 1958).

CANTO, V. M. S.; BERNARDY, E. Análise do direcionamento que é dado ao ensino de língua portuguesa a nível de escola. Signo, Santa Cruz do Sul, n. 12, p. 17-28, 1982.

CRUZ, Celene Margarida e AGUIAR, V. O sujeito enunciador e o discurso por ele produzido no processo de aquisição oral de uma língua estrangeira. Cadernos de estudos lingüísticos, Campinas, n. 3, p. 84-91, 1982.

DORFMAN, Ariel; MATTELART, Armand. Para ler o Pato Donald. Rio de Janeiro: Paz e Terra, 1976.

FISCHER, Rosa Maria Bueno. A questão das técnicas didáticas. Cadernos da FIDENE, Ijuí, 1976. mimeo.

GERALDI, João Wanderley. Subsídios metodológicos para o ensino de língua portuguesa. Cadernos da FIDENE, n. 18, p. 70, 1981.

GERALDI, João Wanderley. Possíveis alternativas para o ensino de língua portuguesa. ANDE, n. 4, p. 57-62, 1982.

GNERRE, Maurizzio. Linguagem e poder. Subsídios à proposta curricular de Língua Portuguesa para o $2^{\circ}$ grau: variação lingüística e ensino da língua materna. Secretaria de Estado da Educação, São Paulo, v. IV, 1978.

LAJOLO, Marisa. O texto não é pretexto. In: ZILBERMAN, Regina. (Org.). Leitura em crise na escola: as alternativas do professor. Porto Alegre: Mercado Aberto, 1982. p. 51-62.

LAJOLO, Marisa. O que é literatura. São Paulo: Brasiliense, 1982.

LEMOS, Cláudia T. G. Sobre aquisição de linguagem e seu dilema (pecado) original. Boletim da Abralin, n. 3, p. 97-126, set. 1982.

ORLANDI, Eni Pulcinelli. As histórias das leituras. In: ESTUDOS LINGÜíSTICOS. 26., 1983, Piracicaba. Seminários do grupo de estudos lingüisticos: anais. Piracicaba: UNIMEP, 1983.

9. $O$ circuito do livro e a escola

AUTHIER-REVUZ, Jacqueline. Hétérogénéité montrée et hétérogénéité constitutive: élements pour une approche de l'autre dans le discours. Revue de Linguistique, DRLAV, n. 26, p. 91-151, 1982.

FREIRE, Paulo. A importância do ato de ler. São Paulo: Autores Associados; Cortez Editora, 1982.

GERALDI, João Wanderley. Subsídios metodológicos para o ensino de língua portuguesa: $5^{\text {a }}$ a $8^{\text {a }}$. série. Cadernos da FIDENE, n. 18 , $1981.70 \mathrm{p}$.

GERALDI, João Wanderley. Prática da leitura de textos na escola. In: ENCONTRO ANUAL DA APLL/RS, 2., 29/9 a 1/10/83. (a sair em Leitura: teoria \& prática)

LAJOLO, Marisa. O que é literatura. São Paulo: Brasiliense, 1982.

ORLANDI, Eni Pulcinelli. A produção da leitura e suas condições. Leitura: teoria e prática, Campinas, ano 2, n. 1, p. 20-25, ab. 1983.

RAMOS, Graciliano. Infância. 17. ed. Rio: Record, 1981.

ROVENTA-FRUMUSANI, Daniela. L'argumentation em tant qu'action. Revue Roumaine de Linguistique, ano XXVII, n. 5, p. 457-462, 1982.

11. Escrita, uso da escrita e avaliação

BENVENISTE, Émile. Da subjetividade na linguagem. In: BENVENISTE, Émile. Problemas de lingüística geral. São Paulo: Companhia Editora Nacional: EDUSP, 1976. (Original de 1958).

BRITO, Percival . Em terra de surdos-mudos: um estudo sobre as condições de produção de textos escolares. Trabalhos em Lingüística Aplicada, Campinas, n. 2, 1983.

LEMOS, Cláudia T. G. Redações de vestibular: algumas estratégias. Cadernos de Pesquisa, Fundação Carlos Chagas, São Paulo, n. 23, 1977.

OSAKABE, Haquira. Considerações em torno do acesso ao mundo da escrita. In: ZILBERMAN, Regina. (Org.). Leitura em crise na escola: as alternativas do professor. Porto Alegre: Mercado Aberto, 1982.

PÉCORA, Alcir. Problemas de redação. São Paulo: Martins Fontes, 1983.

${ }^{183} \mathrm{Na}$ coletânea $O$ texto na sala de aula: leitura \& produção (1984), organizada por Geraldi, foram publicados cinco artigos de Geraldi. Desses artigos, apenas o artigo "Unidades básicas do ensino de português" não possui referências bibliográficas. Neste instrumento de pesquisa, ordeno as referências bibliográficas dos outros artigos de Geraldi, incluindo o artigo publicado em co-autoria com Maria Nilma Góes da Fonseca. Os artigos estão aqui numerados na ordem em que são apresentados na coletânea. 
2. GERALDI, João Wanderley. (Org.). O texto na sala de aula. São Paulo: Ática, 1997. 136 p. (Primeira edição modificada). (3. ed., 1999; 3. ed./3. reimp., 2001; 3. ed./5. reimp., 2002). ${ }^{184}$

AUTHIER-REVUZ, Jacqueline. Hétérogénéité montrée et hetérogénéité constitutive: éléments pour une approche de l'autre dans le discours. Revue de linguistique. DRLAV, p. 91-151, 1982.

BENVENISTE, Ėmile. Da subjetividade na linguagem. In: BENVENISTE, Émile. Problemas de lingüística geral. São Paulo: Companhia Editora Nacional; EDUSP, 1976. (Original de 1958).

BENVENISTE, Émile. O aparelho formal da enunciação. In: BENVENISTE, Émile. Problemas de lingüistica geral. São Paulo: Pontes, 1986. v. 2.

CANTO, V. M. S.; BERNARDY, E. Análise do direcionamento que é dado ao ensino de língua portuguesa a nível de escola. Signo, Santa Cruz do Sul, n. 12, p. 17-28, 1982.

CÂMARA, J. M. Erros ortográficos como sintomas de tendências lingüísticas no português do Rio de Janeiro. In: CÂMARA, J. M. Dispersos. Rio de Janeiro: Fundação Getúlio Vargas. 1972.

CHOMSKY, Noam. Aspectos da teoria da sintaxe. Coimbra: Armênio Amado, 1965.

CRUZ, Celene Margarida; AGUIAR, V. L. O sujeito enunciador e o discurso por ele produzido no processo de aquisição oral de uma língua estrangeira. Cadernos de estudos lingüísticos, Campinas, n. 3, p. 84-91, 1982.

DORFMAN, Ariel; MATTELART, Armand. Para ler o Pato Donald. Rio de Janeiro: Paz e Terra, 1976.

FAVRY, R. L'enseigment de la littérature. Paris: Plon; Cerisy-la-Salle, 1969.

FIRTH, J. R. La sémantique de la science linguistique. In: JACOB, A. (Org.). Gènese de la pensée linguistique. Paris: Armand Colin, 1973.

FISCHMAN, Joshua. Sociologia del lenguaje. Madri: Cátedra, 1975.

FISCHER, Rosa Maria Bueno. A questão das técnicas didáticas. FIDENE, Ijuí, 1976.

FOUCAULT, Michael. L'ordre du discours. Paris: Gallimard, 1971.

FREIRE, Paulo. A importância do ato de ler. São Paulo: Autores Associados; Cortez, 1982.

GERALDI, João Wanderley. Subsídios metodológicos para o ensino de língua portuguesa. Cadernos da FIDENE, Ijuí, n. 18, p. 70, 1981.

GERALDI, João Wanderley. Possíveis alternativas para o ensino da língua portuguesa. ANDE, n. 4, p. 57-62, 1982.

GNERRE, Maurizzio. Linguagem e poder. Subsídios à proposta curricular de lingua portuguesa para o segundo grau: variação lingüística e o ensino da língua materna. Secretaria do Estado da Educação, São Paulo, v. IV, 1978.

LAJOLO, Marisa. Usos e abusos da literatura na escola: Bilac e a literatura escolar na República Velha. Rio de Janeiro: Globo, 1982.

LAJOLO, Marisa. O que é literatura. São Paulo: Brasiliense, 1982.

LAJOLO, Marisa. O texto não é pretexto. In: ZILBERMAN, Regina. (Org.). Leitura em crise na escola: as alternativas do professor. Porto Alegre: Mercado Aberto, 1982. p. 51-62.

LEMOS, Cláudia T. G. Redações de vestibular: algumas estratégias. Cadernos de Pesquisa, São Paulo, n. 23, 1977.

LEMOS, Cláudia T. G. Sobre aquisição de linguagem e seu dilema (pecado) original. ABRALIN, n. 3, p. 97-126, set. 1982.

MELLO, Guiomar Namo de. Fatores intra-escolares como mecanismos de seletividade no ensino de primeiro grau. Educação \& Sociedade, n. 2, p. 70-7, 1979.

ORLANDI, Eni Pulcinelli. A produção da leitura e suas condições. Leitura: teoria e prática, Campinas, ano 2, n. 1, p. 20-5, abril 1983.

OSAKABE, Haquira. Argumentação e discurso político. São Paulo: Kairós, 1979.

OSAKABE, Haquira. Considerações em torno do acesso ao mundo da escrita. In: ZILBERMAN, Regina. (Org.). Leitura em crise na escola: as alternativas do professor. Porto Alegre: Mercado Aberto, 1982.

PÉCORA, Alcir. Problemas de redação. São Paulo: Martins Fontes, 1983.

PÉCORA, Antônio A. B. Problemas de redação na universidade. 1980. Tese (Mestrado) - UNICAMP, Campinas.

POSSENTI, Sírio. Sobre discurso e texto: imagem e/de constituição. In: POSSENTI, Sírio. Sobre a estrutura do discurso. Campinas: Editora da UNICAMP, 1981.

RAMOS, Graciliano. Infância. Rio de Janeiro: Record, 1981.

ROVENTA-FRUMUSANI, Daniela. L'argumentation en tant qu'action. Revue Roumaine de Linguistique, ano 27, n. 5, p. 457-62, 1982.

SOARES, Magda Becker. Aprendizagem da língua materna: problemas e perspectivas. Em aberto, ano 2, n. 12, 1983.

\section{EM CAPÍTULOS DE LIVROS - como autor}

1. GERALDI, João Wanderley. Linguagem e ação. In: SCOZ, Beatriz Judith Lima et al. Psicopedagogia: contextualização, formação e atuação profissional. Porto Alegre: Artes Médicas, 1991. p. 19-25.

ALBANO, Eleonora Cavalcante. Da fala à linguagem tocando de ouvido. São Paulo: Martins Fontes, 1990.

BAKHTIN, Mikhail. Marxismo e filosofia da linguagem. Tradução de Michel Laud e Yara Frateschi Vieira. 2. ed. São Paulo: Hucitec, 1981. BATISTA, Antonio Augusto G. Aula de Português: discurso, conhecimento e escola. 1990. Dissertação (Mestrado) - FAE, Universidade Federal de Minas Gerais, Belo Horizonte.

BRANDÃO, Helena Nagamine. Dialogismo e polifonia enunciativa: análise do discurso da propaganda. 1988. Tese (Doutorado), PUC, São Paulo.

DUCROT, Oswald. La preuve et le dire. Paris: Mame, 1973.

DUCROT, Oswald. O dizer e o dito. Tradução de Eduardo Guimarães et al. Campinas: Pontes, 1987. (Original de 1984).

FIORIN, José Luiz. O regime de 1964: discurso e ideologia. São Paulo: Atual Editora, 1988.

GERALDI, João Wanderley. Portos de passagem. São Paulo: Martins Fontes, 1991.

GUIMARÃES, Eduardo Roberto Junqueira. Texto e argumentação. Campinas: Pontes, 1988.

MANACORDA, Mário A. História da educação: da Antigüidade aos nossos dias. Tradução de Gaetano Lo Mônaco. São Paulo: Cortez; Autores Associados, 1989.

SEARLE, John R. Speech Acts: an essay in the phisolophy of language. Cambridge: Cambridge University Press, 1969.

SMOLKA, Ana Luiza Bustamante. A prática discursiva na sala de aula: uma perspectiva teórica e um esboço de análise. Cadernos CEDES, Campinas, n. 24, p. 51-65, 1991.

WHITAKER-FRANCHI, Regina C. M. Correlação entre estruturas causativas e estruturas ergativas: estudo de caso no processo de aquisição. Cadernos de estudos lingüísticos, Campinas, n. 17, p. 163-185, 1989.

${ }^{184}$ As referências bibliográficas contidas na coletânea $O$ texto na sala de aula, publicada em 1997, apresentam modificações com relação às referências da coletânea publicada em 1984. Por esse motivo, ordeno as referências da edição de 1997. Com relação à edição comemorativa da coletânea, publicada em 2005, ela não apresenta modificações quanto às referências em comparação à edição da coletânea de 1997. Por esse motivo, neste instrumento de pesquisa, não ordeno as referências da edição de 2005. 
2. GERALDI, João Wanderley. O professor como leitor do texto do aluno. In: MARTINS, Maria Helena (Org.). Questões de linguagem. São Paulo: Contexto, 1991. p. 47-53.

FIAD, Raquel Salek. Operações lingüísticas presentes nas reescritas de textos. In: CONGRESSO INTERNACIONAL DA ALFAL, 9. Campinas, agosto de 1990.

GERALDI, João Wanderley. Portos de passagem. São Paulo: Martins Fontes, 1991.

HUBNER, Regina Maria. (Org.). Quando o professor se resolve. São Paulo: Edições Loyola, 1989.

3. GERALDI, João Wanderley. A leitura em momento de crise social. In: ABREU, Márcia. Leituras no Brasil. Campinas: ALB/Mercado de Letras, 1995. p. 179-192.

ANDRADE, Carlos Drummond de. Mãos dadas. In: BARATA, Manoel Sarmento. Canto melhor: uma perspectiva da poesia brasileira. Rio de Janeiro: Paz e Terra, 1969.

AULER, Marcelo. Sangue dos inocentes. Veja, 14 jul. 1993.

BRECHT, Bertold. Poemas e canções. Tradução de Geir Campos. Rio de Janeiro: Civilização Brasileira, 1966.

CANETTI, Elias. A língua absolvida: história de uma juventude. Tradução de Kurt Jahn. São Paulo: Cia. das Letras, 1987.

CAPINAN, José Carlos. Inquisitorial. In: BARATA, Manoel Sarmento. Canto melhor: uma perspectiva da poesia brasileira. Rio de Janeiro: Paz e Terra, 1969.

DANTAS, Francisco J. C. Coivara da Memória. São Paulo: Estação Liberdade, 1991.

FRANCISCATO, Carlos. Corrupção: punição de PC começa pelo crime menor. Jornal Zero Hora, Porto Alegre, 11 jul. 1993.

FREIRE, Paulo. Professora sim, tia não: cartas a quem ousa ensinar. São Paulo: Editora Olho d'água, 1993.

OSAKABE, Haquira. Ensino de gramática e ensino de literatura: a propósito do texto de Lígia Chiappini Moraes Leite. Linha d'Água, São Paulo, 1988.

SCHWARTZ, Roberto. Nacional por Subtração: que horas são? São Paulo: Cia. Das Letras, 1987.

4. GERALDI, João Wanderley. Da sala de aula à construção externa da aula. In: ZACCUR, Edwiges. $A$ magia da linguagem. Rio de Janeiro: DP\&A, 1999. p. 123-140.

ABAURRE, Maria Bernadete; FIAD, Raquel Salek; MAYRINK-SABINSON, Maria Laura. Cenas de aquisição da escrita: o sujeito e o trabalho com o texto. Campinas: Mercado de Letras; ALB, 1997.

BABO, Maria Augusta. A escrita: uma paixão devoradora? Revista de Comunicação e Linguagem, Lisboa, n. 5, p. 29-44, 1987.

BACK, Eurico. Fracasso do ensino de português: proposta de solução. Petrópolis: Vozes, 1987.

BAKHTIN, Mikhail. Gêneros discursivos. In: BAKHTIN, Mikhail. Estética da criação verbal. São Paulo: Martins Fontes, 1986. (Original de 1952).

BASTOS, Lúcia K.; MATTOS, Maria Augusta. A produção escrita e a gramática. São Paulo: Martins Fontes, 1986.

BRITTO, Luiz Percival Leme. A sombra do caos: ensino de língua x tradição gramatical. Campinas: Mercado de Letras; ALB, 1997.

CARVALHO, José Augusto. Por uma política do ensino da língua. Porto Alegre: Mercado Aberto, 1988.

CRUZ, Celene Margarida; JOUËT-PASTRE, C. M. O texto literário em uma classe de língua estrangeira. Campinas, [198?]. (Texto inédito).

DACANAL, José Hildebrando. Linguagem, poder e ensino da língua. Porto Alegre: Mercado Aberto, 1985.

DUARTE, Cristiane. Uma análise de procedimentos de leitura baseada no paradigma indiciário. 1998. Dissertação (Mestrado em Lingüística) - Instituto de Estudos da Linguagem, Universidade Estadual de Campinas, Campinas.

GALLO, Solange L. Discurso da escrita e ensino. Campinas: Editora da UNICAMP, 1992.

GEBARA, Ana Elvira L. O poema, um texto marginalizado. In: CHIAPPINI, Ligia. Aprender e ensinar com textos didáticos e paradidáticos. São Paulo: Cortez, 1997.

GERALDI, João Wanderley. O texto na sala de aula. Cascavel: ASSOESTE, 1984.

ILARI, Rodolfo. A lingüistica e o ensino da língua portuguesa. São Paulo: Martins Fontes, 1985.

KLEIMAN, Ângela. Texto e leitor. Campinas: Pontes, 1989.

LEITE, Lígia Chiappini. Invasão da Catedral: literatura e ensino em debate. Porto Alegre: Mercado Aberto, 1983.

LUFT, Celso Pedro. Língua e liberdade: o gigolô das palavras, por uma nova concepção da língua materna. Porto Alegre: L\&PM, 1985.

PARMIGIANI, Tânia R. Poesia na escola: presença/ausência. 1996. Dissertação (Mestrado em Lingüística) - Instituto de Estudos da Linguagem, Universidade Estadual de Campinas, UNICAMP, Campinas.

POSSENTI, Sírio. Por que (não) ensinar gramática na escola. Campinas: Mercado de Letras;ALB, 1996.

SANTOS, Boaventura de Sousa. Um discurso sobre as ciências. Porto: Afrontamento, 1987.

SILVA, Ezequiel Teodoro. A produção da leitura na escola. São Paulo: Ática, 1995.

ZILBERMAN, Regina. (Org.). A leitura em crise na escola: as alternativas do professor. Porto Alegre: Mercado Aberto, 1982.

ZILBERMAN, Regina; SILVA, Ezequiel Teodoro. (Org.). Leitura: perspectivas interdisciplinares. São Paulo: Ática, 1988.

5. GERALDI, João Wanderley. A presença do texto na sala de aula. In: LARA, Gláucia Muniz Proença. (Org.). Lingua(gem), texto, discurso: entre a reflexão e a prática. Rio de Janeiro: Lucerna; Belo Horizonte: FALE/UFMG, 2006. p. 13-29. v. 1.

BAKHTIN, Mikhail. Estética da criação verbal. São Paulo: Martins Fontes, 1992.

BARBOSA, Marinalva Vieira. Entre o sim e o não, a permanência - o discurso do graduando em Letras sobre o ensino da língua materna. 2004. Dissertação (Mestrado em Lingüística) - Instituto de Estudos da Linguagem, Universidade Estadual de Campinas, Campinas.

CARVALHO, J. Mesquita. Grammatica e anthologia nacional - 3ª e 4 ${ }^{\text {a }}$. série. Porto Alegre: Edição da Livraria do Globo, 1936.

CAVALCANTI, Jauranice Rodrigues. No "mundo dos jornalistas": discursividade, identidade, ethos e gêneros. 2006. Tese (Doutorado em Lingüística) - Instituto de Estudos da Linguagem, Universidade Estadual de Campinas, Campinas.

COUTO, Mia. Luso-afonias - a lusofonia entre viagens e crimes. Questão, Universidade do Algarve, n. 1, 2004.

FRANCHI, Carlos. Criatividade e gramática. CENP/Secretaria de Educação do Estado de São Paulo, São Paulo, 1988.

GERALDI, João Wanderley. Portos de passagem. São Paulo: Martins Fontes, 1991.

MENDONÇA, Maria Clélia. A luta pelo direito de dizer a língua: a lingüística e o purismo lingüístico na passagem do século XX para o século XXI. 2006. Tese (Doutorado em Lingüística) - Instituto de Estudos da Linguagem, Universidade Estadual de Campinas, Campinas. PINTO, Alfredo Clemente. Selecta em prosa e verso dos melhores autores brasileiros e portugueses. 40. ed. Porto Alegre: Livraria Selbach de J. R. da Fonseca \& Cia., 1930

6. GERALDI, João Wanderley. Leitura: uma oferta de contrapalavras. In: MIOTELLO, Valdemir et al. O espelho de Bakhtin. São Carlos: Pedro \& João Editores, 2007. p. 39-46.

BABO, Maria Augusta. A escrita: uma paixão devoradora? Revista de Comunicação e Linguagens, n. 5, p. 29-44, 1987. 
BAKHTIN, Mikhail. Marxismo e filosofia da linguagem. Tradução de Michel Laud e Yara Frateschi Vieira. 2. ed. São Paulo: Hucitec, 1981. BAKHTIN, Mikhail. Observações sobre a epistemologia das ciências humanas. In: BAKHTIN, Mikhail. Estética da criação verbal. São Paulo: Martins Fontes, 1992.

CERTEAU, Michel de. A invenção do cotidiano: artes de fazer. Petrópolis: Vozes, 1994.

ECO, Umberto. A ilha do dia anterior. Rio de Janeiro: Record, 1995.

FOUCAULT, Michel. A ordem do discurso. São Paulo: Loyola, 1996. (Original de 1971).

MELO NETO, João Cabral. Antologia Poética. Rio de Janeiro: Sabiá, 1967.

TOLSTOI, Leo. História de um cavalo. In: TOLSTOI, Leo. Senhor e servo. São Paulo: Clube do Livro, 1953.

\section{EM ARTIGOS EM PERIÓDICOS \\ 3.1 Em artigos em periódicos - como autor}

1. GERALDI, João Wanderley. Possíveis alternativas para o ensino da língua portuguesa. $A N D E$, São Paulo, ano 1, n. 4, p. 52-56, 1982.

GNERRE, Maurizzio. Linguagem e poder. Subsídios à proposta curricular de Língua Portuguesa para o $2^{\circ}$ grau: variação lingüística e ensino da língua materna. Secretaria de Estado da Educação, São Paulo, v. IV, 1978.

MELLO, Guiomar Namo de. Fatores intra-escolares como mecanismos de seletividade no ensino de $1^{\circ}$. grau. Educação \& Sociedade, n. 2, p. 70-77, 1979.

SALGADO, M.U.C. O papel da didática na formação do professor. ANDE, ano 1, n. 4, 1982.

2. GERALDI, João Wanderley. Aprende-se a escrever escrevendo. Signo, Santa Cruz do Sul, ano 10, n. 16, p. 27-31, 1985.

ILARI, Rodolfo. Uma noção sobre redação escolar. Estudos lingüisticos, GEL/FAFIL, n. 2, p. 82-101, 1978.

3. GERALDI, João Wanderley. Prática de produção de textos na escola. Trabalhos em lingüística aplicada, Campinas, n. 7, p. 23-29, 1986. ${ }^{185}$

BENVENISTE, Émile. Da subjetividade na linguagem. In: BENVENISTE, Émile. Problemas de lingüistica geral. São Paulo: Companhia Editora Nacional; EDUSP, 1976. (Original de 1958).

BRITTO, Percival Luiz Leme. Em terra de surdos-mudos: um estudo sobre as condições de produção de textos escolares. In: GERALDI, João Wanderley. O texto na sala de aula: leitura \& produção. Cascavel: Assoeste, 1984. p. 109-119.

OSAKABE, Haquira. Considerações em torno do acesso ao mundo da escrita. In: ZILBERMAN, Regina. (Org.). A leitura em crise na escola. Porto Alegre: Mercado Aberto, 1982.

ROULLET, Edy. Pragmatique et pédagogie: apprendre à comuniquer c'est apprendre à negocier. Langues et Linguistique, n. 11, p. 39-57, 1985.

4. GERALDI, João Wanderley. Aprende-se a escrever escrevendo. Leitura: estudos lingüísticos e literários, Maceió, n. 1, p. 51-55, 1987.

ILARI, Rodolfo. Uma noção sobre redação escolar. Estudos lingüisticos, GEL/FAFIL, n. 2, p. 82-101, 1978.

5. GERALDI, João Wanderley. A leitura na sala de aula: as muitas faces de um leitor. Idéias, São Paulo, n. 5, p. 79-84, 1988.

ADAM, J. M. Texte et représentation dans de sequences argumentatives et descriptives. Travaux du Centre de Recherches Sémiologiques, n. 55 , p. $71-87,1988$.

BAKHTIN, Mikhail. Marxismo e filosofia da linguagem. Tradução de Michel Laud e Yara Frateschi Vieira. 2. ed. São Paulo: Hucitec, 1981. (Original de 1929).

BEISIEGEL, C. R. Política educacional e programas de alfabetização. Idéias, São Paulo, p. 16-22, 1988.

BORDIEU, Pierre. Choses dites. Paris: Minuit, 1987.

ECO, Umberto. Lector in Fabula. São Paulo: Perspectiva, 1986. (Original de 1979).

FALL, Khadiyatoulah. Linguistique et didactique de la lecture. Langues et Linguistique, n. 14, p. 71-88, 1988.

CURSO DE DINAMIZAÇ̃̃O DA LEITURA. São Paulo: FDE, 1987.

MARCUSCHI, Luis Antonio. A propósito de estratégias jornalísticas. Série Estudos, Uberaba, n. 8, p. 18-23, 1982.

MIÉVILLE, Denis. Description et representation. Travaux du Centre de Recherches Sémiologiques, n. 55, p. 147-164, 1988.

ORLANDI, Eni Pulcinelli. Discurso e leitura. São Paulo: Cortez; Editora da UNICAMP, 1988.

SOARES, Magda Becker. As condições sociais da leitura: uma reflexão em contraponto. In: ZILBERMAN, Regina \& SILVA, Ezequiel Teodoro. (Org.). Leitura: perspectivas interdisciplinares. São Paulo: Ática, 1988. p. 18-29.

ZILBERMAN, Regina; SILVA, Ezequiel Teodoro. (Org.) Leitura: perspectivas interdisciplinares. São Paulo: Ática, 1988.

6. GERALDI, João Wanderley. Texto: um problema para o exercício da capatazia. Contexto \& educação, Ijuí, n. 16, p. 79-85, 1989.

ALTHUSSER, Louis. Freud Lacan-Marx e Freud. Rio de Janeiro: Graal, 1985.

BAKHTIN, Mikhail. Marxismo e filosofia da linguagem. Tradução de Michel Laud e Yara Frateschi Vieira. 2. ed. São Paulo: Hucitec, 1981. BAKHTIN, Mikhail. Problemas da poética de Dostoievski. Rio de Janeiro: Forense Universitária, 1981.

CANDIDO, Antonio. Vários escritos. 2. ed. São Paulo: Duas cidades, 1977.

CHAVES, Flavio Loureiro. O mundo social do Quincas Borba. Porto Alegre: Movimento, 1974.

7. GERALDI, João Wanderley. Abordagem sócio-interacionista no ensino, leitura e escrita. Revista de educação AEC, Brasília, n. 101, p. 71-81, 1996.

${ }^{185}$ O texto "Prática de produção de textos na escola" foi publicado como texto em anais no ano de 1986. 
AZEVEDO, Claudinéia; TARDELLI, Marlene C. Escrevendo e falando em sala de aula. In: GERALDI, João Wanderley. (Org.). Aprender e ensinar com textos. São Paulo: FFLCH/USP, 1994.

BAKHTIN, Mikhail. Observações sobre a epistemologia das ciências humanas. In: Estética da criação verbal. São Paulo: Martins Fontes, 1992. (Original de 1974).

JESUS, Conceição Aparecida. Reescrita: para além da higienização. 1995. Dissertação (Mestrado em Lingüística) - Instituto de Estudos da Linguagem, Universidade Estadual de Campinas, Campinas.

LARROSA, Jorge. Pedagogia, experiência e subjetividade: uma exploração da experiência do livro e da formação do leitor à educação humanística. In: SILVA \& AZEVEDO. (Orgs.). Reestruturação curricular: teoria e prática no cotidiano da escola. Petrópolis: Vozes, 1995.

LEGRAND-GELBER, Régine. De l'homogénéité du dialogue pédagogique a l'hétérogénéité des interacions didactiques. Cahiers de Linguistique Sociale, n. 12, p. 86-88, 1988.

RAMA, Angel. A cidade das letras. São Paulo: Brasiliense, 1984.

ROULET, Eddy. Pragmatique et pédagogie: apprendre à communiquer, c'est apprendre à négocier. Langues et Linguistique, n. 11, p. 390$57,1985$.

SILVA, Ana Claudia; CARBONARI, Rosemeire. Cópia e leitura oral: estratégias para ensinar? In: BRANDÃO, Helena Nagamine; MICHELETTI, Guaraciaba. (Orgs.). Aprender e ensinar com textos: aprender e ensinar com textos didáticos e paradidáticos. São Paulo: FFLCH/USP, 1994. v. II.

SMOLKA, Ana Luíza Bustamante. A criança na fase inicial da escrita: a alfabetização como processo discursivo. São Paulo: Cortez; Campinas: Editora da UNICAMP, 1988.

TEIXEIRA, Elisa. Sobre o que se escreve a escola. In: GERALDI, João Wanderley. (Org.). Aprender e ensinar com textos. São Paulo: FFLCH/USP, 1994.

VARLOTTA, Yêda Maria da Costa. Capacitação e mudança, de desempenho do professor: ecos de vozes em um discurso tecido na/pela interlocução entre a teoria construída e a experiência vivida. 1996. Dissertação (Mestrado em Psicologia da Educação) - Pontifícia Universidade Católica, São Paulo.

\subsection{Em artigos em periódicos - como co-autor}

1. GERALDI, João Wanderley; ABAURRE, Maria Bernadete; SABINSON, Maria Laura T. Mayrink; FIAD, Raquel Salek. Considerações sobre a utilização de um paradigma indiciário na análise de episódios de refacção textual. Trabalhos em lingüística aplicada, Campinas, n. 25, p. 5-23, 1995.

ABAURRE-GNERRE, Maria Bernadete M.; CAGLIARI, Luis Carlos. Textos espontâneos na $1^{\text {a }}$ série: evidências de utilização, pela criança, da sua percepção fonética da fala para representar e segmentar a escrita. Cadernos CEDES, n. 14, p. 25-29, 1985.

ABAURRE-GNERRE, Maria Bernadete M. O que revelam os textos espontâneos sobre a representação que faz a criança do objeto escrito? In: KATO, Mary. (Org.). A concepção da escrita pela criança. Campinas: Pontes Editores, 1988.

ABAURRE-GNERRE, Maria Bernadete M. The interplay between spontaneous writing and underlying linguistic representations. European Journal of Psychology of Education, vol. III, n. 4, p. 415-430, 1988.

ABAURRE-GNERRE, Maria Bernadete M. Oral and written texts: Beyond the descriptive illusion of similaritties and differences. Instituto de Estudos da Linguagem, Universidade Estadual de Campinas, 1989. Inédito.

ABAURRE-GNERRE, Maria Bernadete M. Língua oral, língua escrita: interessam, à lingüística, os dados da aquisição da representação escrita da linguagem? In: CONGRESSO INTERNACIONAL DA ALFAL, 9., 1990, Campinas. Anais... Campinas: IEL/UNICAMP, 1990. (A sair).

ABAURRE-GNERRE, Maria Bernadete M. Ritmi dell'oralità e ritmi della scritura. IN: ORSOLINI, M. e PONTECORVO, C. (Orgs.). La costruzione del texto scritto nei bambini. Firenze: La Nuova Itália Editrice, 1991.

ABAURRE-GNERRE, Maria Bernadete M. Os estudos lingüísticos e a aquisição da escrita. In: ENCONTRO NACIONAL SOBRE AQUISIÇÃO DA LINGUAGEM. 2., 1991, Porto Alegre, PUCRS. Anais... Porto Alegre: PUCRS, 1991.

BORDIEU, Pierre. Introdução a uma sociologia reflexiva. In: BORDIEU, Pierre. O poder simbólico. Lisboa: Difel; Rio de Janeiro: Bertrand, 1989.

DA SILVA, A. Alfabetização: a escrita espontânea. São Paulo: Editora Contexto, 1991.

FERREIRO, Emilia; Ana, TEBEROSKY. Los sistemas de escritura em el desarrollo del Niño. Cidade do México: Siglo Veintiuno Editores, 1979.

FERREIRO, Emilia. Introduction. European Journal of Psychology of Education, v. III, n. 4, p. 365-370, 1988. (Número especial sobre Early Literacy).

FIAD, Raquel Salek. O professor escrevendo e ensinando a escrever. Contexto e Educação, Ijuí, n. 16, 1989.

FIAD, Raquel Salek. Operações lingüísticas presentes na reescrita de texto. Revista internacional de língua portuguesa, Lisboa, n. 4, 1991.

FIAD, Raquel Salek, MAYRINK-SABINSON, Maria Laura. A escrita como trabalho. In: MARTINS, Maria Helena. (Org.). Questões de linguagem. São Paulo: Martins Fontes, 1991.

GINZBURG, Carlo. Chaves do mistério: Morelli, Freud e Sherlock Holmes. In: ECO, Umberto; SEBEOK, T. A. O signo de três. São Paulo: Perspectiva, 1983. p. 89-129.

GINZBURG, Carlo. Mitti Emblemi Spie: morfologia e storia. Tradução de Frederico Carotti. Torino: Einaudi. (Tradução brasileira: Mitos, emblemas e sinais: morfologia e história. São Paulo: Companhia das Letras, 1986.)

MAYRINK-SABINSON, Maria Laura. Os papéis da interação e do interlocutor adulto na constituição da escrita como objeto de atenção da criança. Instituto de Estudos da Linguagem, Universidade Estadual de Campinas, 1989. (Inédito).

MAYRINK-SABINSON, Maria Laura. A respeito do reconhecimento de letras ou de como uma criança pequena pode pensar que a letra tem um proprietário. In: ESTUDOS LINGÜÍSTICOS, 23., 1991, Franca. Anais do Seminário do GEL, Franca, 1991.

MAYRINK-SABINSON, Maria Laura. Para que serve a escrita quando você ainda não sabe ler/escrever? Leitura: teoria \& prática, Porto Alegre, n. 16, 1991.

MAYRINK-SABINSON, Maria Laura. Reflexões sobre o processo de aquisição da escrita. Campinas: Editora da UNICAMP, 1991.

PÊCHEUX, Michel. O discurso: estrutura ou acontecimento. Campinas: Fontes, 1990. (Original de 1988).

QUARTAROLLA, A. A. Relatório de pesquisa/CNPq. 1994. (Inédito).

SERRANI, Silvana Mabel. A linguagem na pesquisa sociocultural: um estudo da repetição na discursividade. Campinas: Editora da UNICAMP, 1993. 
2. GERALDI, João Wanderley; COLlARES, Cecília Azevedo Lima; MOYSÉS, Maria Aparecida Affonso. As aventuras do conhecer: da transmissão à interlocução. Educação \& sociedade, Campinas, ano 23, n. 78, p. 91-116, abr. 2002.

BAKHTIN, Mikhail. Estética da criação verbal. São Paulo: Martins Fontes, 1992. (Original de 1920-1930).

BOLTANSKY, Luc. As classes sociais e o corpo. 3 ed. Rio de Janeiro: Graal, 1989.

BORGES, Jorge Luís. Obras completas. São Paulo: Globo, 1999. v. II. (O fazedor)

CANGUILHEM, George. O normal e o patológico. 2 ed. brasileira. Rio de Janeiro: Forense-Universitária, 1982.

CARO, Paul. A roda das ciências: do cientista à sociedade, os itinerários do conhecimento. Lisboa: Instituto Piaget, 1995.

COLLARES, Cecília Azevedo Lima; MOYSÉS, Maria Aparecida Affonso. Preconceitos no cotidiano escolar: ensino e medicalização. São Paulo: Cortez; Campinas: FE/FCM UNICAMP, 1996.

FOUCAULT, Michel. A ordem do discurso. São Paulo: Edições Loyola, 1996. (Original de 1971).

FOUCAULT, Michel. Vigiar e punir: nascimento da prisão. 14 ed. brasileira. Petrópolis: Vozes, 1996. (Original de 1977).

HELLER, Agnes. O cotidiano e a história. 3 ed. Rio de Janeiro: Paz e Terra, 1989.

JULLIEN, François. A arte do desvio. In: MORIN, Edgar et al. A sociedade em busca de valores: para fugir à alternativa entre o cepticismo e o dogmatismo. Lisboa: Instituto Piaget, 1996.

LARROSA, Jorge. Pedagogia profana. Belo Horizonte: Autêntica, 1999.

MORIN, Edgar. Epistemologia da complexidade. In: SCHNITMAN, Dora Fried. (Org.). Novos paradigmas, cultura e subjetividade. Porto Alegre: Artes Médicas, 1996.

MORIN, Edgar. Complexidade e liberdade. In: MORIN, Edgar et al. A sociedade em busca de valores: para fugir à alternativa entre o cepticismo e o dogmatismo. Lisboa: Instituto Piaget, 1996.

MORIN, Edgar. A noção de sujeito. In: SCHNITMAN, Dora Fried. (Org.). Novos paradigmas, cultura e subjetividade. Porto Alegre: Artes Médicas, 1996.

MORIN, Edgar. Amor, poesia, sabedoria. Lisboa: Instituto Piaget, 1999. (Original francês de 1997).

MOYSÉS, Maria Aparecida Affonso. A institucionalização invisível: crianças que não-aprendem-na-escola. 1998. Tese de livre-docência em Pediatria Social, Faculdade de Ciências Médicas, UNICAMP, Campinas.

MOYSÉS, Maria Aparecida Affonso; COLLARES, Cecília Azevedo Lima. O buraco negro entre o conhecimento cientifico e o mundo real: um objeto essencial de pesquisa. In: REALI, A. M.; MIZUKAMI, M. G. Formação do educador: tendências atuais. São Carlos: Editora da UJFSCar. 1997

PRIGOGINE, Ilya. O reencantamento do mundo. In: MORIN, Edgar et al. A sociedade em busca de valores: para fugir à alternativa entre o cepticismo e o dogmatismo. Lisboa: Instituto Piaget, 1998.

PRIGOGINE, Ilya. O fim da ciência? In: SCHNITMAN, Dora Fried. (Org.). Novos paradigmas, cultura e subjetividade. Porto Alegre: Artes Médicas, 1996.

RAUX, Jean-François. Elogio da Filosofia para construir um modo melhor. In: MORIN, Edgar et al. A sociedade em busca de valores: para fugir à alternativa entre o cepticismo e o dogmatismo. Lisboa: Instituto Piaget, 1996.

SANTOS, Boaventura de Souza. Um discurso sobre as ciências. Lisboa: Afrontamento, 1987.

SARAMAGO, José. Ensaio sobre a cegueira. São Paulo: Companhia das Letras, 1995.

SCHNITMAN, Dora Fried. Introdução: ciência, cultura e subjetividade. In: SCHNITMAN, Dora Fried. (Org.). Novos paradigmas, cultura e subjetividade. Porto Alegre: Artes Médicas, 1996.

\section{EM TEXTOS EM ANAIS DE EVENTOS - como autor}

1. GERALDI, João Wanderley. De como produzir milagres ou o professor pega um boizinho, rifa e compra livros. In: CONGRESSO DE LEITURA DO BRASIL, 5., 1986, Campinas. Comunicações oficiais: anais. Campinas: ALB, 1986. p. 43-50.

ALMEIDA, Júlia Lopes de. A nossa língua. In: ALMEIDA, Júlia Lopes de. Histórias da nossa terra. 7. ed. Rio de Janeiro: Francisco Alves, 1911.

BUTAKA, I. et al. Prática da leitura extensiva em escolas estaduais de $1^{\circ}$ grau: Minas Gerais - Estudo Exploratório. In: CONGRESSO DE LEITURA DO BRASIL, 3., 1981, Campinas. Resumos..., Campinas: UNICAMP, 1981. p. 71-76.

FOUCAULT, Michel. A ordem do discurso. Tradução de Sírio Possenti e revisão de Dinarte Belatto e José Crippa. Cadernos da FIDENE, Ijuí, 1971.

GERALDI, João Wanderley. Prática da leitura de textos na escola. In: GERALDI, João Wanderley. O texto na sala de aula: leitura \& produção. Cascavel: Assoeste, 1984. p. 77-92.

LAJOLO, Marisa. O que é literatura. São Paulo: Brasiliense, 1982.

LAJOLO, Marisa. Poesia: uma frágil vítima de manuais escolares. Leitura: teoria \& prática, ano 3, n. 4, p. 19-25, 1984.

LAJOLO, Marisa. A teoria da literatura e a leitura na escola. In: SEMINÁRIO, 1985, Porto Alegre. As ciências da linguagem e a formação do leitor. Porto Alegre, 22 a 24 agos. 1985.

OSAKABE, Haquira. Considerações em torno do acesso ao mundo da escrita. In: ZILBERMAN, Regina. (Org.). Leitura em crise na escola: as alternativas do professor. Porto Alegre: Mercado Aberto, 1982.

2. GERALDI, João Wanderley. Sobre a constituição dos objetos de ensino em língua materna. In: COLÓQUIO SOBRE QUESTÕES CURRICULARES, 4., 2000. Braga. Políticas curriculares: caminhos da flexibilização e integração: actas. Universidade do Minho (Braga): Centro de Estudos em Educação e Psicologia, 2000. p. 369-378.

ABAURRE, Maria Bernadete; FIAD, Raquel Salek; MAYRINK-SABINSON, Maria Laura. Cenas de aquisição da escrita: o sujeito e o trabalho com o texto. Campinas: Mercado de Letras/ALB, 1997.

BABO, Maria Augusta. A escrita: uma paixão devoradora? Revista de Comunicação e Linguagem, Lisboa, n. 5, p. 29-44, 1987.

BACK, Eurico. Fracasso do ensino de português: proposta de solução. Petrópolis: Vozes, 1987.

BAKHTIN, Mikhail. Gêneros discursivos. In: BAKHTIN, Mikhail. Estética da criação verbal. São Paulo: Martins Fontes, 1986. (Original de 1952).

BASTOS, Lúcia K.; MATTOS, Maria Augusta. A produção escrita e a gramática. São Paulo: Martins Fontes, 1986.

BRITTO, Luiz Percival Leme. A sombra do caos: ensino de língua x tradição gramatical. Campinas: Mercado de Letras/ALB, 1997.

CARVALHO, José Augusto. Por uma política do ensino da língua. Porto Alegre: Mercado Aberto, 1988.

CRUZ, Celene Margarida; JOUËT-PASTRE, C. M. O texto literário em uma classe de língua estrangeira. Campinas, [198?]. (Texto inédito).

DACANAL, José Hildebrando. Linguagem, poder e ensino da língua. Porto Alegre: Mercado Aberto, 1985. 
DUARTE, Cristiane. Uma análise de procedimentos de leitura baseada no paradigma indiciário. 1998. Dissertação (Mestrado em Lingüística) - Instituto de Estudos da Linguagem, Universidade Estadual de Campinas, Campinas.

GALLO, Solange L. Discurso da Escrita e Ensino. Campinas: Editora da UNICAMP, 1992.

GEBARA, Ana Elvira L. O poema, um texto marginalizado. In: CHIAPPINI, Ligia. Aprender e ensinar com textos didáticos e paradidáticos. São Paulo: Cortez, 1997.

GERALDI, João Wanderley. O texto na sala de aula. Cascavel: Assoeste, 1984

ILARI, Rodolfo. A lingüística e o ensino da língua portuguesa. São Paulo: Martins Fontes, 1985.

KLEIMAN, Ângela. Texto e leitor. Campinas: Pontes, 1989.

LARROSA, Jorge. Agamenon e seu porqueiro: notas sobre a produção, a dissolução e o uso da realidade nos aparatos pedagógicos e nos meios de comunicação. In: LARROSA, Jorge. Pedagogia profana. Porto Alegre: Contra*Bando, 1998.

LEITE, Lígia Chiappini. Invasão da Catedral: literatura e ensino em debate. Porto Alegre: Mercado Aberto, 1983.

LUFT, Celso Pedro. Lingua e liberdade: o gigolô das palavras, por uma nova concepção da língua materna. Porto Alegre: L\&PM, 1985.

PARMIGIANI, Tânia R. Poesia na escola: presença/ausência. 1996. Dissertação (Mestrado em Lingüística) - Instituto de Estudos da Linguagem, Universidade Estadual de Campinas, UNICAMP, Campinas.

POSSENTI, Sírio. Por que (não) ensinar gramática na escola. Campinas: Mercado de Letras/ALB, 1996.

SANTOS, Boaventura de Sousa. Um discurso sobre as ciências. Porto: Afrontamento, 1987.

SILVA, Ezequiel Teodoro. A produção da leitura na escola. São Paulo: Ática, 1995.

ZILBERMAN, Regina. (Org.). A leitura em crise na escola: as alternativas do professor. Porto Alegre: Mercado Aberto, 1982.

ZILBERMAN, Regina; SILVA, Ezequiel Teodoro. (Orgs.). Leitura: perspectivas interdisciplinares. São Paulo: Ática, 1988. 


\section{INSTITUIÇÕES, ACERVOS E CATÁLOGOS DIGITAIS E BASES DE DADOS DE BIBLIOTECAS UNIVERSITÁRIAS DISPONÍVEIS ON-LINE CONSULTADOS Acervos}

Acervo do Grupo de Pesquisa "História do Ensino de Língua e Literatura do Brasil" Faculdade de Filosofia e Ciências — Universidade Estadual Paulista — Marília-SP.

Biblioteca da Faculdade de Educação (FE) — Universidade Estadual de Campinas — Campinas-SP.

Biblioteca do Instituto de Estudos Brasileiros (IEB) - Universidade de São Paulo — São Paulo-SP.

Biblioteca do Instituto de Estudos Linguísticos (IEL) - Universidade Estadual de Campinas Campinas-SP.

CEDAE - Centro de Documentação Cultural "Alexandre Eulálio" - Instituto de Estudos da Linguagem - Universidade Estadual de Campinas - Campinas-SP.

Serviço de Biblioteca da Faculdade de Ciências e Letras - Universidade Estadual Paulista Araraquara-SP.

Serviço de Biblioteca da Faculdade de Filosofia e Ciências - Universidade Estadual Paulista Marília-SP.

Serviço de Biblioteca do Instituto de Biociências, Letras e Ciências Exatas (IBILCE) — Universidade Estadual Paulista - São José do Rio Preto-SP.

Serviço de Biblioteca e Documentação da Faculdade de Educação - Universidade de São Paulo — São Paulo-SP.

Serviço de Biblioteca e Documentação da Faculdade de Filosofia, Letras e Ciências Humanas Universidade de São Paulo - São Paulo-SP.

\section{Bases de dados de bibliotecas universitárias disponíveis on-line}

Base de dados Acervus - Sistema de Bibliotecas da Universidade Estadual de Campinas. Disponível em: $<\underline{\text { http://www.unicamp.br/bc/ }>\text {. }}$

Base de dados Athena - Faculdade de Filosofia e Ciências - Universidade Estadual Paulista. Disponível em: <http://www.athena.biblioteca.unesp.br/F?RN=672374846>.

Base de dados CEDAE - Centro de Documentação "Alexandre Eulálio" - Faculdade de Educação - Universidade Estadual de Campinas. Disponível em: $<$ http://www.cedae.iel.unicamp.br/biblioteca/catalogos.php $>$.

Base de dados Dedalus - Faculdade de Educação - Universidade de São Paulo. Disponível em: <http://dedalus.usp.br:4500/ALEPH/por/USP/USP/DEDALUS/START>.

Base de dados de Unidades de I\&D - Universidade do Porto/Portugal. Disponível em: $<$ http://www.fct.mctes.pt/unidades/index.asp?p=3\&u=22>.

Base de dados Minerva - Universidade Federal do Rio de Janeiro. Disponível em: $<$ http://fenix.ufrj.br:4505/ALEPH $>$. 
Base de dados Scientifc Eletronic Library Online - SCIELO - Disponível em: $<$ http://www.scielo.br/scielo.php?>. 
APÊNDICE C

Formação acadêmica de J. W. Geraldi: um instrumento de pesquisa 
LUZIA DE FÁTIMA PAULA

FORMAÇÃO ACADÊMICA DE J. W. GERALDI: UM INSTRUMENTO DE PESQUISA

Universidade Estadual Paulista

Faculdade de Filosofia e Ciências

Campus de Marília

Marília - SP

Dezembro de 2009 


\section{SUMÁRIO}

APRESENTAÇÃ̃

1. FORMAÇÃO ACADÊMICA DE GERALDI NO ESTADO DO 3 RIO GRANDE DO SUL

2. FORMAÇÃO ACADÊMICA DE GERALDI NO IEL/UNICAMP, 10 CAMPINAS/SP. 


\section{APRESENTAÇÃO}

Para a elaboração deste instrumento de pesquisa, utilizei os procedimentos de localização, recuperação, reunião, seleção e ordenação de documentos referentes à formação acadêmica de J. W. Geraldi, linguista gaúcho que se destaca no ensino de língua portuguesa no Brasil.

Para alcançar os objetivos propostos, realizei visita a dois acervos na Universidade Estadual de Campinas (UNICAMP), localizada na cidade de Campinas-SP: Centro de Documentação Cultural "Alexandre Eulálio" (CEDAE), situado no Instituto de Estudos da Linguagem (IEL); e o Arquivo Central do Sistema de Arquivos (SIARQ).

No SIARQ, localizei informações referentes à história do IEL, de seus docentes e alunos, assim como da grade curricular do curso de Pós-Graduação em meados da década de 1970, no período em que Geraldi cursou o mestrado, de 1976 a 1978, bem como sobre a década de 1980 a 1990, quando se encerrou o seu doutorado, visando, a partir de tais informações, a obtenção de detalhes relativos à formação desse linguista.

Neste instrumento de pesquisa, apresento informações relevantes sobre as pesquisas realizadas em cada um desses acervos, inclusive as fontes documentais localizadas sobre o IEL/UNICAMP, que contêm informações sobre a formação acadêmica de Geraldi. 


\section{FORMAÇÃO ACADÊMICA DE J. W. GERALDI NO ESTADO DO RIO GRANDE DO SUL}

No primeiro acervo visitado, CEDAE, situado no piso térreo do bloco VII do IEL, localizado à rua Cora Coralina, s/n, na Cidade Universitária “Zeferino Vaz", em Barão Geraldo, na UNICAMP, em Campinas-SP, não localizei as informações que buscava. Nesse acervo, consta o conjunto de fundos pessoais de escritores e intelectuais brasileiros e também institucionais, que se referem às principais associações linguísticas brasileiras e latinoamericanas, e coleções documentais sobre temas relativos à literatura e linguística brasileiras.

No segundo acervo visitado, SIARQ, o qual está localizado à Praça Henfil, n. 50, na cidade Universitária "Zeferino Vaz", em Barão Geraldo, Campinas-SP, localizei um documento no qual constava o levantamento de dados históricos sobre o IEL.

Dentre outros servidores, Telma Maria Murari é a responsável pelo Serviço de Arquivo Permanente.

Listo abaixo cinco fontes de pesquisa consultadas:

1. Conselho Diretor, Atas, livro 2, 1968-69, cx. 20;

2. Processo $n^{o}$. 2965/72 - Reconhecimento dos cursos de bacharelado de Ciências Sociais, de Economia e de Lingüística ministrados pelo Instituto de Filosofia e Ciências Humanas (IFCH), v. I;

3. Processo $n^{o}$. 2965/72 - Reconhecimento dos cursos de bacharelado de Ciências Sociais, de Economia e de Lingüística ministrados pelo Instituto de Filosofia e Ciências Humanas (IFCH), v. II;

4. Processo $n^{\circ}$. 7968/76 - Constituição do Instituto de Estudos de Linguagem;

5. Iel, notas sobre a Unicamp e o Iel, 1982.

Dessas fontes de pesquisa consultadas, solicitei cópia em papel dos seguintes documentos:

1. Reflexões sobre o novo Instituto de Lingüística e Estudos Literários, Prof. Dr. Aryon D. Rodrigues, sem data;

2. Notas sobre o Instituto de Estudos da Linguagem, Prof. Ataliba Teixeira de Castilho, dezembro de 1982; 
3. Processo $n^{o}$. 7968/76 - Constituição do Instituto de Estudos de Linguagem. Instituto de Estudos da Linguagem (Iel). p. 6-10.

E cópia digitalizada dos documentos abaixo relacionados:

1. 1 cópia de um diploma de João Wanderley Geraldi da década de 1960 e 24 cópias de diplomas e certificados da década de 1970, sem páginas;

2. Processo $n^{o}$. 2965/72I, v. II. Currículo de Carlos Franchi. p. 500-501;

3. Processo $n^{o}$. 2965/72I, v. II. Currículo de Haquira Osakabe. p. 502-503;

4. Processo $n^{o}$. 2965/72I, v. II. Currículo de Rodolfo Ilari. p. 504-506;

5. Processo $n^{o}$. 2965/72I, v. II. Currículo de Oswald Ducrot. p. 507-510;

6. Processo $n^{o}$. 2965/72I, v. II. Disciplinas do tronco comum de Lingüística. p. 23, $24,25,26,27,28,29,30,31,32,33,34,35,36,44,45,46,47,48,49,50,51,52$, 53 ;

7. Processo $n^{o}$. 2965/72I, v. II. Corpo Docente do Departamento de Lingüística. p. 371.

As visitas a esses dois acervos na UNICAMP, CEDAE e SIARQ, possibilitaram-me melhor compreender questões sobre a formação do linguista J. W. Geraldi, a partir do "lugar" de onde ele obteve parte de sua formação. Ressalto que venho analisando os textos desse autor desde o ano de 2002, por ocasião de minha pesquisa em nível de mestrado.

A partir da localização do Processo $n$. 7968/76, 1972, volume I, no SIARQ, foi possível recuperar informações sobre 11 cursos realizados por Geraldi no período compreendido entre 1972 e 1978.

No quadro 1, abaixo, apresento as informações que constam desses documentos, e, consequentemente, parte da formação acadêmica de Geraldi, que ocorreu em instituições localizadas no interior do estado do Rio Grande do Sul. 


\section{Quadro 1 - Formação acadêmica de Geraldi em instituições do estado do Rio Grande do Sul}

\begin{tabular}{|c|c|c|c|c|}
\hline CURSOS & $\begin{array}{c}\text { LOCAIS DE } \\
\text { REALIZAÇÃ } \\
\text { O }\end{array}$ & $\begin{array}{c}\text { DOCENTES } \\
\text { RESPONSÁVEIS }\end{array}$ & $\begin{array}{l}\text { CONTEÚDOS } \\
\text { MINISTRADOS }\end{array}$ & REALIZAÇÃO \\
\hline $\begin{array}{l}\text { 1. "Renovação } \\
\text { da Gramática } \\
\text { à luz } \\
\text { Da Lingüística" }\end{array}$ & $\begin{array}{l}\text { Faculdader de } \\
\text { Filosofia, Ciências } \\
\text { e Letras } \\
\text { "Imaculada } \\
\text { Conceição" } \\
\text { (Agregada à } \\
\text { Universidade } \\
\text { Federal de Santa } \\
\text { Maria-RS) }\end{array}$ & $\begin{array}{l}\text { Prof. Dr. Silvio Elia, } \\
\text { Prof. Dr. Eurico } \\
\text { Back, Prof. Dr. } \\
\text { Wilson Guarany }\end{array}$ & $\begin{array}{l}\text { I. Introdução à Lingüística (30 } \\
\text { horas-aula - Prof. Wilson } \\
\text { Guarany) } \\
\text { 1.0 Problemas de metanálise } \\
\text { 1.1 Lingǘstica e ciência } \\
\text { 1.2 Filologia, Lingǘstica e } \\
\text { Gramática } \\
\text { 1.3 Metalinguagem } \\
\text { 1.4 Estrutura e estruturalismo } \\
\text { 1.5 Noção de modelo } \\
\text { 1.6 Descrição lingüística, } \\
\text { coerência e dedutibilidade } \\
\text { 1.7 Imanência e pertinência } \\
\text { 2.0 Problemas de análise } \\
\text { 2.1 As dicotomias saussurianas } \\
\text { 2.2 Fonética e Fonologia } \\
\text { 2.3 A Sintaxe Distribucional e a } \\
\text { Sintaxe Transformacional } \\
\text { 2.4 O significado: a análise } \\
\text { sêmica } \\
\text { II. Lingüística construtural (30 } \\
\text { horas-aula-Prof. Eurico Back) } \\
\text { 1.1 Paralinguagem } \\
\text { metalinguagem e } \\
\text { 1.2 Variáveis e constantes. } \\
\text { Estilística } \\
\text { 1.3 Estudo do significante } \\
\text { 1.4 Semântica } \\
\text { 1.5 "performance") } \\
\text { 1.6 Lingüística aplicada } \\
\text { III. Gramática transformacional } \\
\text { (15 horas-aula - Prof. Silvio E. } \\
\text { Elia) gridade } \\
\text { 1.1 Antecedentes da gramática } \\
\text { gerativo-transformacional } \\
\text { 1.2 Gramaticalidade } \\
\text { 1.3 Estruturas de base: sintagma } \\
\text { nominal, sintagma verbal, } \\
\text { sintagma } \\
\text { sintagma adjetival } \\
\text { 1.4 Transformações }\end{array}$ & 1972 \\
\hline $\begin{array}{l}\text { 2. "Lingüística } \\
\text { aplicada ao } \\
\text { ensino de língua } \\
\text { nacional" }\end{array}$ & $\begin{array}{l}\text { Faculdade de } \\
\text { Filosofia, Ciências } \\
\text { e Letras de Santo } \\
\text { Ângelo }\end{array}$ & $\begin{array}{l}\text { Prof. Sebastião José } \\
\text { Votre, Anselmo } \\
\text { Berwanger, Angelo } \\
\text { Dante Biz e Arieta } \\
\text { Antas }\end{array}$ & 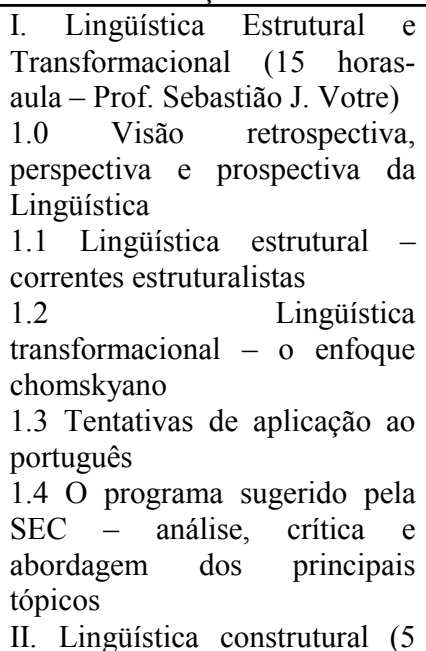 & 1972 \\
\hline
\end{tabular}




\begin{tabular}{|c|c|c|c|c|}
\hline & & & $\begin{array}{l}\text { horas-aula - Prof. Anselmo } \\
\text { Berwanger) } \\
\text { 1.1 Tentativa de uma teoria } \\
\text { globalizante } \\
\text { 1.2 Relações estruturais } \\
\text { 1.3 Modelos de análise } \\
\text { III. Semântica (5 horas-aula - } \\
\text { Prof. Ângelo Dante Biz) } \\
\text { 1.1 O sentido do sentido } \\
\text { 1.2 Tipos de sentido (sentido } \\
\text { denotativo, sentido conotativo, } \\
\text { sentido estrutural) } \\
\text { IV. Estruturas sintáticas (5 } \\
\text { horas-aula - Profa. Arieta } \\
\text { Antas) } \\
1.1 \text { Partes do discurso e } \\
\text { palavras funcionais } \\
1.2 \text { Processos de substituição } \\
1.3 \text { Operações de expansão } \\
\text { básica } \\
1.4 \text { Transformações simples } \\
1.5 \text { Operações de oração } \\
\text { subordinativa }\end{array}$ & \\
\hline $\begin{array}{l}\text { 3. "Filosofia e } \\
\text { linguagem" }\end{array}$ & $\begin{array}{l}\text { Faculdade de } \\
\text { Filosofia, Ciências } \\
\text { e Letras de Santo } \\
\text { Ângelo }\end{array}$ & $\begin{array}{ll}\text { Professores do } \\
\text { Departamento de } \\
\text { Filosofia e Letras da } \\
\text { Federe }\end{array}$ & $\begin{array}{l}\text { 1. O projeto metafísico do } \\
\text { Ocidente (16 horas-aula) } \\
\text { 1.1 Mito e logos } \\
\text { 1.2 Platão (o pensamento grego) } \\
1.3 \text { O pensamento teológico- } \\
\text { metafísico da Idade Média } \\
\text { 1.4 A modernidade: o saber } \\
\text { moderno e a subjetividade } \\
\text { 1.5 O iluminista: racionalista, } \\
\text { empirista, idealista } \\
\text { 1.6 O idealismo alemão: Kant e } \\
\text { Hegel } \\
1.7 \text { Marx e as descontinuidades } \\
\text { históricas } \\
\text { 1.8 O processo de destruição do } \\
\text { projeto metafísico: Nietzche, } \\
\text { Freud, Marx } \\
2 . \text { A crise do pensamento } \\
\text { contemporâneo (12 horas-aula) } \\
2.1 \text { Heidegger } \\
2.2 \text { Sartre } \\
\text { 2.3 "A estrutura, o signo e o } \\
\text { jogo no discurso das ciências } \\
\text { humanas" } \\
3 . \text { O problema da linguagem } \\
\text { (12 horas-aula) } \\
\text { 3.1 A linguagem: a fala, a } \\
\text { escuta e a resposta } \\
\text { 3.2 Prolegômenos para uma } \\
\text { teoria da linguagem } \\
3.3 \text { As ordens do discurso } \\
3.4 \text { "Poemas de Fernando } \\
\text { Pessoa" }\end{array}$ & 1973 \\
\hline $\begin{array}{l}\text { 4. "Lingüística } \\
\text { aplicada ao a } \\
\text { português" }\end{array}$ & $\begin{array}{l}\text { Faculdade de } \\
\text { Filosofia, Ciências } \\
\text { e Letras - } \\
\text { Universidade } \\
\text { Federal de Santa } \\
\text { Maria }\end{array}$ & $\begin{array}{l}\text { Prof. José Olavo } \\
\text { Neis, Prof. Sebastião } \\
\text { José Votre e Prof. } \\
\text { Celso Pedro Luft }\end{array}$ & $\begin{array}{l}\text { Prof. José Olavo Neis } \\
\text { - Possibilidades de } \\
\text { aprendizagem de uma língua } \\
\text { estrangeira } \\
\text { - Métodos mais difundidos de } \\
\text { ensino } \\
\text { - Aprendizagem de idiomas } \\
\text { - Vantagens e desvantagens dos } \\
\text { métodos estruturais } \\
\text { - O recurso dos auxílios áudio- } \\
\text { visuais }\end{array}$ & 1973 \\
\hline
\end{tabular}




\begin{tabular}{|c|c|c|c|c|}
\hline & & & $\begin{array}{l}\text { Prof. Sebastião José Votre } \\
\text { - Modalidades de abordagem } \\
\text { gramatical de uma língua } \\
\text { - Gramática transformacional } \\
\text { VS Gramática Estrutural } \\
\text { - O profissional do ensino da } \\
\text { língua } \\
\text { - Vantagens de um bom } \\
\text { treinamento lingüístico } \\
\text { - Gramática transformacional e } \\
\text { o ensino da composição } \\
\text { - Lingüística, usos e usuários } \\
\text { - Como não interferir na } \\
\text { aprendizagem da língua } \\
\text { - Organização estrutural da } \\
\text { linguagem - gramática } \\
\text { Prof. Celso Pedro Luft } \\
\text { - Gramática Transformacional } \\
\text { da Língua Portuguesa } \\
\text { - Conceito de gramática } \\
\text { - Gramática gerativo- } \\
\text { transformacional } \\
\text { - Componentes da gramática e } \\
\text { elaboração de gramáticas } \\
\text { - Derivação e diagramação da } \\
\text { estrutura } \\
\text { - Conceito de transformação } \\
\text { - Transformações simples e } \\
\text { generalizadas } \\
\text { - Nominalização } \\
\text { - Relativização }\end{array}$ & \\
\hline $\begin{array}{l}\text { 5. "Introdução à } \\
\text { Semântica e } \\
\text { Prática de } \\
\text { ensino da língua } \\
\text { portuguesa" }\end{array}$ & $\begin{array}{l}\text { Faculdade de } \\
\text { Filosofia, Ciências } \\
\text { e Letras de Ijuí }\end{array}$ & $\begin{array}{lll}\text { Prof. } & \text { Dr. } & \text { Eurico } \\
\text { Back } & & \end{array}$ & $\begin{array}{l}\text { I. Introdução à Semântica } \\
\text { 1. Comunicação } \\
\text { 2. Análise do sinal } \\
\text { 3. Relações semânticas da } \\
\text { cláusula } \\
\text { 4. Conceito de trajeto semântico } \\
\text { 5. Alinhamento do trajeto } \\
\text { semântico } \\
\text { 6. Trajeto cultural do morfema } \\
\text { II. Prática de ensino de língua } \\
\text { portuguesa } \\
\text { 1. Comunicação } \\
\text { 2. Processos genéticos de } \\
\text { aprendizagem } \\
\text { 3. Criatividade } \\
\text { 4. Planejamento do ensino } \\
\text { 5. Execução do ensino }\end{array}$ & 1973 \\
\hline $\begin{array}{l}\text { 6. "1 }{ }^{\circ} \text { Seminário } \\
\text { de Estudos de } \\
\text { Metodologia do } \\
\text { Ensino } \\
\text { Superior" }\end{array}$ & $\begin{array}{l}\text { Faculdade de } \\
\text { Filosofia, } \\
\text { Ciências e Letras } \\
\text { de Santo Ângelo }\end{array}$ & $\begin{array}{l}\text { Profa. Arete } \\
\text { Saldanha Vargas }\end{array}$ & $\begin{array}{l}\text { (45 horas-aula) } \\
\text { I. A formação de recursos } \\
\text { humanos para a educação e a } \\
\text { universidade do Rio Grande do } \\
\text { Sul } \\
\text { II. Estrutura regimental da } \\
\text { Faculdade } \\
\text { III. Cursos e currículos } \\
\text { IV. Conteúdos programáticos } \\
\text { V. Planejamento de atividades }\end{array}$ & 1974 \\
\hline $\begin{array}{l}\text { 7. "Problemas } \\
\text { de poética e } \\
\text { lingüística } \\
\text { portuguesa" }\end{array}$ & $\begin{array}{lr}\text { Faculdade } & \text { de } \\
\text { Filosofia, Ciências } \\
\text { e Letras } & \text { Dom } \\
\text { Bosco, } & \text { Santa } \\
\text { Rosa-RS } & \\
\end{array}$ & $\begin{array}{l}\text { Prof. Dr. Wilson } \\
\text { Guarany e Prof. } \\
\text { Celso Pedro Luft }\end{array}$ & - & 1974 \\
\hline $\begin{array}{l}\text { 8. "Problemas } \\
\text { de Comunicação } \\
\text { e Linguagem" }\end{array}$ & $\begin{array}{l}\text { Faculdade de } \\
\text { Filosofia, Ciências } \\
\text { e Letras de Santo } \\
\text { Ângelo }\end{array}$ & - & $\begin{array}{l}\text { Primeira etapa } \\
\text { 1. Definição do signo: Saussure } \\
\text { e Peirce } \\
\text { 2. Problemas de análise do }\end{array}$ & 1974 \\
\hline
\end{tabular}




\begin{tabular}{|c|c|c|c|c|}
\hline & & & $\begin{array}{l}\text { significado } \\
\text { 3. A Gramática Estratificacional } \\
\text { e o significado } \\
\text { 4. Bernard Pottier e a análise do } \\
\text { significado } \\
\text { 5. A Semântica Estrutural de } \\
\text { Julien Greimas } \\
\text { Segunda etapa } \\
\text { 1. Estruturalismo: aquisições e } \\
\text { limites } \\
\text { 2. Gramática gerativo- } \\
\text { transformacional: aquisições e } \\
\text { limites } \\
\text { 3. Categorias, relações e } \\
\text { transformações do português }\end{array}$ & \\
\hline $\begin{array}{l}\text { 9. "Curso de } \\
\text { aperfeiçoamento } \\
\text { em Filosofia" }\end{array}$ & $\begin{array}{l}\text { Faculdade de } \\
\text { Filosofia, Ciências } \\
\text { e Letras de Ijuí }\end{array}$ & $\begin{array}{l}\text { Prof. Silvino Santin, } \\
\text { Prof. José Fagundes } \\
\text { e Euclides Redin }\end{array}$ & $\begin{array}{l}\text { - Antropologia Filosófica (75 } \\
\text { horas-aula Prof. Silvino Santin) } \\
\text { - História da Filosofia ( } 75 \\
\text { horas-aula. Prof. José } \\
\text { Fagundes) } \\
\text { - Metodologia do Ensino } \\
\text { Superior ( } 30 \text { horas-aula Prof. } \\
\text { Euclides Redin) } \\
\text { - Estudos dos problemas } \\
\text { brasileiros (15 horas-aula Prof. } \\
\text { Silvino Santin) }\end{array}$ & 1975 \\
\hline $\begin{array}{l}\text { 10. "Curso de } \\
\text { Especialização } \\
\text { em Lingüística" }\end{array}$ & $\begin{array}{l}\text { Faculdade de } \\
\text { Filosofia, Ciências } \\
\text { e Letras de Ijuí }\end{array}$ & $\begin{array}{l}\text { Prof. Dr. Aryon D. } \\
\text { Rodrigues e Profa. } \\
\text { Ms. Maria. T. } \\
\text { Mayrink }\end{array}$ & $\begin{array}{l}\text { - Organização da Gramática e } \\
\text { Fonologia (6 créditos - Prof. Dr. } \\
\text { Aryon D. Rodrigues) } \\
\text { - Introdução à Gramática: } \\
\text { Gerativa: Sintaxe (6 créditos - } \\
\text { Prof. Dr. Aryon D. Rodrigues) } \\
\text { - Fonologia do Português (10 } \\
\text { créditos - Prof. Dr. Aryon D. } \\
\text { Rodrigues e Profa. Ms. Maria. } \\
\text { T. Mayrink) } \\
\text { - Monografia(2 créditos - Prof. } \\
\text { Dr. Aryon D. Rodrigues) }\end{array}$ & 1976 \\
\hline $\begin{array}{l}\text { 11. "Encontro } \\
\text { de professores } \\
\text { de cursos de } \\
\text { Letras do Rio } \\
\text { Grande do Sul" }\end{array}$ & $\begin{array}{ll}\text { Associação } & \text { de } \\
\text { Escolas } & \\
\text { Superiores } & \text { de } \\
\text { Formação } & \text { de } \\
\text { Profissionais } & \text { do } \\
\text { Ensino } & \\
\text { (AESOFUPE) } & - \\
\text { DAU/SEC/RS } & - \\
\text { PUC-RS } & \end{array}$ & - & 20 horas-aula & 1978 \\
\hline
\end{tabular}

Fonte: Processo n. 7968/76, 1972, volume I

Os 11 cursos que localizei são: "Renovação da Gramática à luz da Lingüística", "Lingüística aplicada ao ensino de língua nacional”, "Filosofia e linguagem", "Lingüística aplicada ao português", "Introdução à Semântica e Prática de ensino da língua portuguesa", “1. Seminário de Estudos de Metodologia do Ensino Superior", "Problemas de poética e lingüística portuguesa", "Problemas de Comunicação e Linguagem”, "Curso de aperfeiçoamento em Filosofia", "Curso de Especialização em Lingüística" e "Encontro de professores de cursos de Letras do Rio Grande do Sul”. 
Apresento, na mesma ordem, os professores responsáveis por cada um desses cursos: Angelo Dante Biz, Anselmo Berwanger, Aretê Saldanha Vargas, Arieta Antas, Aryon Dall'Igna Rodrigues, Celso Pedro Luft, Euclides Redin, Eurico Back, José Fagundes, José Olavo Neis, Maria Laura Trindade Mayrink, Sebastião Josué Votre, Silvino Santin, Silvio Elia e Wilson Guarany.

Esses cursos tematizavam assuntos relativos às diversas áreas linguísticas: gramática, filologia, fonética, fonologia, semântica, linguística aplicada, discurso, poética, comunicação e ensino de língua portuguesa.

\section{FORMAÇÃO ACADÊMICA DE GERALDI NO IEL/UNICAMP, CAMPINAS/SP}

Reconhecendo a importância da formação de Geraldi no IEL/UNICAMP, por ocasião da realização de seus cursos de mestrado e doutorado, concluídos respectivamente em 1978 e 1990, além das fontes documentais localizadas no SIARQ, como mencionei acima, localizei também informações sobre os primeiros professores que atuavam no IEL/UNICAMP, no ano de 1978. Essas informações, apresentadas no quadro 2, abaixo, constam do periódico Cadernos de estudos lingüisticos (1978), n. 1. 


\section{Quadro 2 - Docentes do Departamento de Linguística do IEL/UNICAMP, no ano de 1978}

\begin{tabular}{|c|c|c|}
\hline $\begin{array}{l}\text { OCORRÊN- } \\
\text { CIA }\end{array}$ & DOCENTES & FORMAÇÃO EM 1978 \\
\hline 1 & Ângela Bustos Kleiman & Doutora pela Universidade de Illinois \\
\hline 2 & Antônio Carlos Quícoli & Doutor pela Universidade de Nova Iorque \\
\hline 3 & Aryon Dall'Igna Rodrigues & Doutor pela Universidade de Hamburgo \\
\hline 4 & Ataliba Teixeira de Castilho & Doutor pela Universidade de São Paulo \\
\hline 5 & Brian Franklin Head & Doutor pela Universidade do Texas \\
\hline 6 & Carlos Franchi & $\begin{array}{l}\text { Doutor pela Universidade Estadual de } \\
\text { Campinas }\end{array}$ \\
\hline 7 & Carlos Alberto Vogt & $\begin{array}{l}\text { Doutor pela Universidade Estadual de } \\
\text { Campinas }\end{array}$ \\
\hline 8 & Clarice Sabóia Madureira & $\begin{array}{l}\text { Mestre pela Universidade Estadual de } \\
\text { Campinas }\end{array}$ \\
\hline 9 & Cláudia Theresa Guimarães de Lemos & Doutora pela Universidade de Edimburgo \\
\hline 10 & Ester Mirian Scarpa Gebara & $\begin{array}{l}\text { Mestre pela Universidade Estadual de } \\
\text { Campinas }\end{array}$ \\
\hline 11 & Frank Roberts Brandon & Doutor pela Universidade do Texas \\
\hline 12 & Haquira Osakabe & $\begin{array}{l}\text { Doutor pela Universidade Estadual de } \\
\text { Campinas }\end{array}$ \\
\hline 13 & Jonas de Araújo Romualdo & $\begin{array}{l}\text { Mestre pela Universidade Estadual de } \\
\text { Campinas }\end{array}$ \\
\hline 14 & Luis Carlos Cagliari & Doutor pela Universidade de Edimburgo \\
\hline 15 & Marcelo Dascal & Doutor pela Universidade de Jerusalém \\
\hline 16 & Marco Antônio de Oliveira & $\begin{array}{l}\text { Mestre pela Universidade Estadual de } \\
\text { Campinas }\end{array}$ \\
\hline 17 & Maria Bernadete Abaurre Gnerre & $\begin{array}{l}\text { Doutora pela Universidade de Nova } \\
\text { Iorque }\end{array}$ \\
\hline 18 & Maria Cecília Perroni Simões & $\begin{array}{l}\text { Mestre pela Universidade Estadual de } \\
\text { Campinas }\end{array}$ \\
\hline 19 & Maria Fausta Pereira de Castro Campos & Mestre pela Universidade de Montpellier \\
\hline 20 & Lucy Seki & $\begin{array}{l}\text { Doutora pela Universidade Amizade dos } \\
\text { Povos }\end{array}$ \\
\hline 21 & Mário Alberto Perini & Doutor pela Universidade do Texas \\
\hline 22 & Maurizzio Gnerre & Doutor pela Universidade de Roma \\
\hline 23 & Michel Lahud & $\begin{array}{l}\text { Mestre pela Universidade de Aix-en- } \\
\text { Provence }\end{array}$ \\
\hline 24 & Rodolfo Ilari & $\begin{array}{l}\text { Doutor pela Universidade Estadual de } \\
\text { Campinas }\end{array}$ \\
\hline 25 & Rosa Attié Figueira & $\begin{array}{l}\text { Mestre pela Universidade Estadual de } \\
\text { Campinas }\end{array}$ \\
\hline 26 & Tânia Maria Alkmin & $\begin{array}{l}\text { Mestre pela Universidade Estadual de } \\
\text { Campinas }\end{array}$ \\
\hline 27 & Vandersi Pereira Sant'ana & $\begin{array}{l}\text { Mestre pela Universidade Estadual de } \\
\text { Campinas }\end{array}$ \\
\hline 28 & Vera Lúcia Maia de Oliveira & $\begin{array}{l}\text { Mestre pela Universidade Estadual de } \\
\text { Campinas }\end{array}$ \\
\hline 29 & Waldyr Carvalho Luz & Doutor pela Universidade de Princeton \\
\hline
\end{tabular}


Naquele momento, em 1978, quando Geraldi finalizou o mestrado em Linguística, compunham o corpo docente do Departamento de Linguística do IEL/UNICAMP os professores: Ângela Del Carmen Bustos Romero de Kleiman, Antônio Carlos Quícoli, Aryon Dall'Igna Rodrigues, Ataliba Teixeira de Castilho, Brian Franklin Head, Carlos Franchi, Carlos Alberto Vogt, Clarice Sabóia Madureira, Cláudia Theresa Guimarães de Lemos, Ester Mirian Scarpa Gebara, Frank Roberts Brandon, Haquira Osakabe, Jonas de Araújo Romualdo, Luis Carlos Cagliari, Marcelo Dascal, Marco Antônio de Oliveira, Maria Bernadete Abaurre Gnerre, Maria Cecília Perroni Simões, Maria Fausta Pereira de Castro Campos, Lucy Seki, Mário Alberto Perini, Maurizzio Gnerre, Michel Lahud, Rosa Attié Figueira, Rodolfo Ilari, Tânia Maria Alkmin, Vandersi Pereira Sant'ana, Vera Lúcia Maia de Oliveira e Waldyr Carvalho Luz.

Esses professores, naquele momento, atuavam nas seguintes linhas de pesquisa: Teoria Linguística, Fonética, Fonologia, Gramática, Variação Linguística, Semântica e Linguística Aplicada. 


\section{Acervos consultados}

CEDAE - Centro de Documentação Cultural "Alexandre Eulálio" - Instituto de Estudos da Linguagem - Universidade Estadual de Campinas - Campinas-SP.

SIARQ - Arquivo Central do Sistema de Arquivos - Universidade Estadual de Campinas Campinas-SP. 